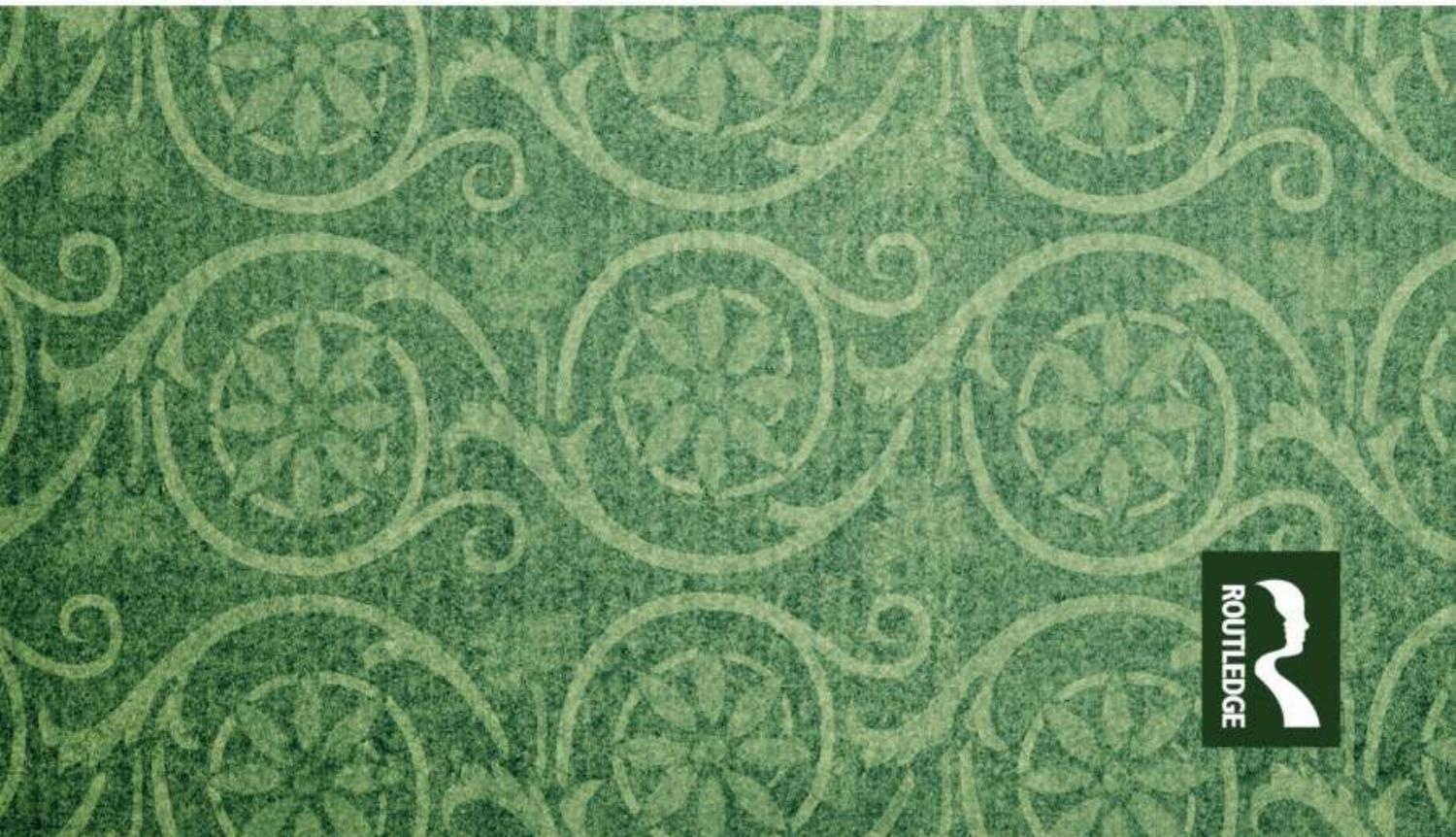




\section{Archives and Human Rights}

Why and how can records serve as evidence of human rights violations, in particular crimes against humanity, and help the fight against impunity? Archives and Human Rights shows the close relationship between archives and human rights and discusses the emergence, at the international level, of the principles of the right to truth, justice and reparation.

Through a historical overview and topical case studies from different regions of the world, the book discusses how records can concretely support these principles. The current examples also demonstrate how the perception of the role of the archivist has undergone a metamorphosis in recent decades, towards the idea that archivists can and must play an active role in defending basic human rights, first and foremost by enabling access to documentation on human rights violations.

Confronting painful memories of the past is a way to make the ghosts disappear and begin building a brighter, more serene future. The establishment of international justice mechanisms and the creation of truth commissions are important elements of this process. The healing begins with the acknowledgement that painful chapters are essential parts of history; archives then play a crucial role by providing evidence. This book is both a tool and an inspiration to use archives in defence of human rights.

Jens Boel is a Danish archivist and historian. He was the Chief Archivist of UNESCO from 1995 to 2017 and Chair of the International Council on Archives' Section of International Organizations 2000-2004 and 2008-2012. He launched the UNESCO History Project in 2004 and is co-editor of Recordkeeping in International Organizations, Routledge, 2020.

Perrine Canavaggio, a French archivist, was Head of the Archives of the Presidency of the Republic (1974-1994). Secretary of the International Conference of the Round Table on Archives (2001-2009), she is a member of the Executive Committee of the ICA Section on Archives and Human Rights.

Antonio González Quintana is a Spanish archivist. He is Chair of the ICA Section on Archives and Human Rights and has been Deputy General Director of Archives in the Community of Madrid (2010-2018). He is the author of Archival Policies in the Protection of Human Rights (2009). 


\section{Routledge Approaches to History}

38 Africa, Empire and World Disorder Selected Essays

A.G. Hopkins

39 History in a Post-Truth World Theory and Praxis

Edited by Marius Gudonis and Benjamin T. Jones

40 The Primacy of Method in Historical Research

Philosophy of History and the Perspective of Meaning Jonas Ablskog

41 Archives and Human Rights

Edited by Jens Boel, Perrine Canavaggio and Antonio González

Quintana

42 Historical Experience

Essays on the Phenomenology of History

David Carr

43 Humanism: Foundations, Diversities, Developments Jörn Rüsen

44 National History and New Nationalism in the Twenty-First Century A Global Comparison

Edited by Niels F. May and Thomas Maissen

45 Family History and Historians in Australia and New Zealand Related Histories

Edited by Malcolm Allbrook and Sophie Scott-Brown

For a full list of available titles please visit: https://www.routledge.com/ Routledge-Approaches-to-History/book-series/RSHISTHRY 


\section{Archives and Human Rights}

\section{Edited by Jens Boel, Perrine Canavaggio and Antonio González Quintana}

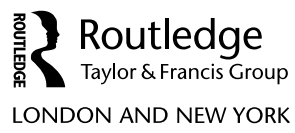


First published 2021

by Routledge

2 Park Square, Milton Park, Abingdon, Oxon OX14 4RN

and by Routledge

52 Vanderbilt Avenue, New York, NY 10017

Routledge is an imprint of the Taylor \& Francis Group, an informa business

(C) 2021 selection and editorial matter, Jens Boel, Perrine Canavaggio and Antonio González Quintana; individual chapters, the contributors

The right of Jens Boel, Perrine Canavaggio and Antonio González Quintana to be identified as the authors of the editorial material, and of the authors for their individual chapters, has been asserted in accordance with sections 77 and 78 of the Copyright, Designs and Patents Act 1988.

All rights reserved. No part of this book may be reprinted or reproduced or utilised in any form or by any electronic, mechanical, or other means, now known or hereafter invented, including photocopying and recording, or in any information storage or retrieval system, without permission in writing from the publishers.

Trademark notice: Product or corporate names may be trademarks or registered trademarks, and are used only for identification and explanation without intent to infringe.

British Library Cataloguing-in-Publication Data

A catalogue record for this book is available from the British Library

Library of Congress Cataloging-in-Publication Data

A catalog record for this book has been requested

ISBN: 978-0-367-15034-1 (hbk)

ISBN: 978-0-367-72460-3 (pbk)

ISBN: 978-0-429-05462-4 (ebk)

Typeset in Sabon

by Apex CoVantage, LLC 
To the memory of Louis Joinet 
$\because$ Taylor \& Francis Taylor \& Francis Group http://taylorandfrancis.com 


\section{Contents}

Acknowledgements $\quad \mathrm{x}$

List of authors xi

Foreword xviii

MICHELLE BACHELET

Message from the President of the International

Council on Archives $\quad \mathrm{xx}$

DAVID FRICKER

Introduction

JENS BOEL, PERRINE CANAVAGGIO AND

ANTONIO GONZÁLEZ QUINTANA

\section{PART 1}

Archives and human rights: a close relationship

JENS BOEL, PERRINE CANAVAGGIO AND ANTONIO

GONZÁLEZ QUINTANA

1 Archives and citizens' rights

2 Records and archives documenting gross human rights violations

3 Archives and transitional justice

4 Archives and the duty to remember 54

5 Archivists for human rights 57

6 Archives and human rights beyond political transitions 
viii Contents

PART 2

Case studies

1 Proof

TRUDY HUSKAMP PETERSON

Africa

2 A long walk to justice: archives and the truth and reconciliation process in South Africa

GRAHAM DOMINY

3 Tunisia's Truth and Dignity Commission: archives in the pursuit of truth

ADEL MAÏZI

4 The exploitation of the archives of Hissène Habrés political police by the Extraordinary African Chambers HENRI THULLIEZ

5 The Gacaca archive: preserving the memory of post-genocide justice and reconciliation in Rwanda PETER HORSMAN

Asia

6 Memory politics and archives in Sino-Japanese relations KARL GUSTAFSSON

7 The use of the archives of the Tuol Sleng Genocide Museum and the Documentation Centre of Cambodia by the Extraordinary Chambers in the Courts of Cambodia VINCENT DE WILDE D'ESTMAEL

\section{Europe}

8 Spanish military documentation on the Civil War and the dictatorship as an instrument of legal reparations for the victims of the Franco regime

HENAR ALONSO RODRÍGUEZ

9 The "Centres of Remembrance" in post-communist Europe 
10 A legacy of the DDR: the Stasi Records Archive DAGMAR HOVESTÄDT

11 France and the archives of the Algerian War GILLES MANCERON AND GILLES MORIN

12 Truth, memory, and reconciliation in post-communist societies: the Romanian experience and the Securitate archives MARIUS STAN AND VLADIMIR TISMANEANU

Latin America

13 Archives for memory and justice in Colombia after the Peace Agreements

RAMON ALBERCH I FUGUERAS

14 Utilisation of the archives of the Peruvian Commission for Truth and Reconciliation (CVR) RUTH ELENA BORJA SANTA CRUZ

15 Archives, truth and the democratic transition process in Brazil

ALUF ALBA VILAR ELIAS

16 Archives for truth and justice in Argentina: the search for the missing persons MARIANA NAZAR

17 Chronicle of a backlash foretold: Guatemala's National Police archives, lost and found and lost - and found? - again

KIRSTEN WELD

Concluding remarks

JENS BOEL, PERRINE CANAVAGGIO AND ANTONIO GONZÁLEZ QUINTANA

Index 


\section{Acknowledgements}

The editors thank all colleagues who have contributed to this book with inspiration and work. In particular, we wish to thank David Sutton for his tireless and precious linguistic support. Those parts of the book which we have submitted for his critical review of language and style, have greatly benefited from his insightful suggestions. We also wish to thank Jean Canavaggio for his generous and invaluable help in translating some of the key texts of the book. Margaret Procter kindly volunteered to translate one of the case studies. Christine Cross, Lauren Elston and Fiona Westbury have translated most of the texts originally written in French, Portuguese and Spanish; we appreciate their professionalism and competent work. Finally, we want to thank our families for their patience and support during the whole editorial process. 


\section{List of authors}

Ramon Alberch i Fugueras has a PhD in history. He is President of Archivist without Borders International since 2012. He is also member of the International Advisory Council of the National Center of Historical Memory of Colombia (2015-2018) and has served as an international consultant for the Special Jurisdiction for Peace (2019). In the 2006-2014 period, he directed the project of recovery and access to documents and archives of repressive regimes in Latin America. He has been Coordinator of the diploma "Archives and human rights. International learning in contexts of (post) conflict" (2015-2016). He is the author of 30 essays and manuals of archives and history, and has been a speaker at numerous international conferences on the subject of archives and human rights.

Henar Alonso Rodríguez is a member of Spain's Corps of Archivists and is a senior expert on Archives, working as Head of the Description Area of the General Military Archive of Avila, one of the Spanish Army's four History Archives, within the Ministry of Defence's Archive System. A graduate in law and postgraduate in European Public Law, she is a member of the Spanish Civil Service Archivists' Association, (AEFP: Archiveros Españoles en la Función Pública) and the Castile and Leon Archivists' Association (ACAL: Asociación de Archiveros de Castilla y León), with which she regularly collaborates over training in the fields of Document Management, Archival Science and Transparency, as well as technical and general interest publications and publicity campaigns on social networks.

Jens Boel is a Danish archivist and historian. He was the Chief Archivist of UNESCO from 1995 to 2017 and Coordinator of the UNESCO History Project from 2004 to 2011. He was Chair of the International Council on Archives (ICA) Section of International Organizations (SIO) 20002004 and 2008-2012 and ICA Vice-President for Sections from 2010 to 2012. He was Director of the Transnational Team of the InterPARES Trust (ITrust) Project from 2013 to 2019. He was co-founder (2003) of the ICA Human Rights and Archives Working Group and currently a 
member of the Executive Committee of the ICA Section on Archives and Human Rights.

Ruth Elena Borja Santa Cruz is a Peruvian historian who graduated from the Universidad Nacional Mayor de San Marcos (UNMSM), where she is now Professor in the History Department of the Social Science Faculty. From 1998 to 2002, she worked at the National Archives (Archivo General de la Nación). She was a member of Peru's Truth and Reconciliation Commission from 2002 to 2003 and worked in the Public Defender's Office (Defensoría del Pueblo) from 2004 to 2012. She has acted as a consultant for the Place of Memory, Tolerance and Social Inclusion (LUM), attended meetings, workshops and colloquia in a number of countries in Europe and the Americas and taken part in various collaborative exchanges on archiving and memory preservation.

Perrine Canavaggio is a French archivist with a diploma from l'Ecole nationale des chartes. She also has a diploma in political science from l'Institut d'études politiques de Paris. She was Chief Curator of the Archives of the Presidency of the French Republic from 1974 to 1994 and Deputy Director of Archives de France in 1995 and 1996. She was Deputy Secretary General of the International Council on Archives (ICA) from 2000 to 2009, Secretary of the International Conference of the Round Table on Archives (CITRA) from 2000 to 2008, co-founder (2003), chair (20032008) and member of the ICA Archives and Human Rights Working Group until 2019 and member of the Executive Committee of the ICA Section on Archives and Human Rights from 2019.

Graham Dominy is Research Fellow of UNISA, the University of South Africa, and of the Helen Suzman Foundation. He is both archivist and historian and was National Archivist of South Africa from 2001 until his retirement in 2014. In his career, he has also worked in museums, libraries, Arts \& Culture and, most recently, as Knowledge \& Collections Specialist in Muscat, Oman. He is the author of two books, Last Outpost on the Zulu Frontiers: Fort Napier and the British Imperial Garrison and The Man Behind the Beard. He has published over 60 academic and professional articles.

Aluf Alba Vilar Elias is an archivist and has a PhD in Information Science from the University of Brasília (UnB). Her research is focused on archival epistemology, discourse analysis and archives of political repression. She works with management and curation of archives and collections and is the head of processing and collection preservation at the National Archives of Brazil.

José M. Faraldo is an associate professor, tenured, at the Universidad Complutense de Madrid (UCM); he has been Ramón-y-Cajal researcher at the UCM (2009-2015). He has a PhD in history from the same university for his work on Russian nationalism. After further studies in history 
and cultural studies in Moscow, Frankfurt/Oder and Poznań he worked, from 1997 to 2002, at the European University Viadrina, in Frankfurt/ Oder (Germany). From 2004 to 2008, he was research fellow and project coordinator at the Center of Research on Contemporary History (Zentrum für Zeithistorische Forschung, ZZF), in Potsdam (Germany). He has published extensively about nationalism in communism, resistance against fascism and communism, exiles from dictatorships and about archives and the legacy of communist secret police, including a first comparison of Soviet, East German, Polish and Romanian communist police agencies (Las redes del terror. Las policías secretas comunistas y su legado, Barcelona, Galaxia Gutenberg 2018).

Antonio González Quintana is a graduate in history (1979), postgraduate in Archival Science (1983) and a member of the Spanish Corps of Archivists (1985). He was Deputy Director General of Archives in the Community of Madrid between 2010 and 2018. Antonio has also served as Director of the Documentary Information Center on Archives of the Ministry of Culture (2006-2008), Head of the Coordination Unit of Military Archives of the Ministry of Defense (1994-2003) and Director of the Civil War Archive (National Archives), in Salamanca (1986-1994). He was Professor of Archival Science at the University of Salamanca between 1989 and 1992. He retired in January 2018. In recent years, he has worked especially on the relationship between Archives and the defence of Human Rights. He is the author of a UNESCO report "Archives of the security services of former repressive regimes" (1995); an updated and further developed version was published by the ICA in 2009 with the title "Archival Policies in the Protection of Human Rights". He has been a member of the Human Rights Working Group of the International Council on Archives since 2003 and he is also a founder member of Archivists without Borders. Today he is Chair of the ICA Section on Archives and Human Rights.

Karl Gustafsson is Associate Professor in the Department of Economic History and International Relations at Stockholm University and Senior Research Fellow at the Swedish Institute of International Affairs. He has recently published peer-reviewed articles in International Relations, Cambridge Review of International Affairs, Journal of International Relations and Development, Survival, European Political Science and Memory Studies. He won the Wang Gungwu prize for best article in Asian Studies Review in 2014.

Peter Horsman was, until his retirement in 2012, a faculty staff of the University of Amsterdam, teaching various aspects of archival science. Previously, he worked with the Netherlands Archives School, and even before it with the municipal archives of Dordrecht and the National Archives of the Netherlands. Currently, he is active as a consultant, mostly in the 
field of (electronic) records and archives management and digital preservation, for both public and private organizations. On behalf of the Netherlands Institute for War, Holocaust and Genocide Studies (NIOD) he is involved in a project of digitising and making available the archives of the genocide courts in Rwanda.

Dagmar Hovestädt is the spokeswoman of the Federal Commissioner for the Stasi Records since 2011. She previously worked as a journalist in Berlin during the time of transition from 1989 to 1999 continuing to report for German media from California from 2000 to 2011. As part of her current duties, she is responsible for the media outreach and the digital efforts to turn the archive into a resource for future generations. She is also working closely with the international visitor community to the archive, is part of an initiative to form an international human rights archive network and is speaking and writing on the role of archives in transitional justice. She received a master's degree in communication and political science from the FU Berlin in 1991.

Adel Maïzi was appointed to the Truth and Dignity Commission (IVD) by the Tunisian National Constituent Assembly. He chaired the IVD's Commission for the Preservation of National Memory and was its Chief Records and Archives Manager throughout its mandate, from 2014 to 2019. Before this, he was Chief Archivist at the Ministry of Finance from 2012 to 2014 . He is also a poet, writer and human rights activist, and Secretary General of the Arab Centre for Transitional Justice.

Gilles Manceron, who began his career as a high school history and geography teacher, was Editor-in-Chief of Hommes \& Libertés, the journal of the French Ligue des droits de l'Homme (LDH), from 1997 to 2005. Vice-President of LDH from 2005 to 2006 and from 2009 to 2011, he is currently joint chairman of its "Memory, History, Archives" working group. He has published several works on colonial history, including Marianne et les colonies (2003), and is president of the Colonial and Post-Colonial History Society (histoirecoloniale.net).

Gilles Morin is a research fellow at the Centre d'histoire sociale des mondes contemporains (University of Paris 1 Pantheon-Sorbonne, UMR-CNRS 8058). He specialises in 20th-century French political and social history and, in 1992, submitted his doctoral thesis on Socialist opposition to the Algerian War, a subject at the interface between colonial and political history. He has co-directed several collective works focusing mainly on the history of the French Socialist Party and is currently working on a publication concerning the National Popular Rally (RNP), one of the main collaborationist parties during World War II. He is a member of the editorial committee of $20 \& 21$. Revue d'histoire (formerly Vingtième siècle. Revue d'histoire), with responsibility for the "archives" section. 
Mariana Nazar is a historian and an archivist. She has worked in the General Archives of the Nation of Argentina since 1998 - initially as a technical assistant of the Intermediate Archives Department and currently as a coordinator of the Training and Archival Development Program of the General Directorate. She has been archival advisor to social, political and union organizations and lecturer at the Department of History of the Faculty of Philosophy and Letters of the University of Buenos Aires. Since 2018, she teaches and collaborates as Academic Coordinator of the Diploma in General Archiving of the National University of Tres de Febrero. She is a member of the Executive Committee of the Iberarchivos Program, Vice President of the Section on Archives and Human Rights of the International Council on Archives (ICA) and Coordinator of the Archives and Human Rights Working Group of the Latin American Archives Association (ALA).

Trudy Huskamp Peterson, an archival consultant with a $\mathrm{PhD}$ from the University of Iowa, is a Certified Archivist, an ex-chair of the Human Rights Working Group of the International Council on Archives and a writer of its monthly newsletter, ex-president of the Society of American Archivists and the International Conference of the Round Table on Archives and the author of books and articles on the archives of truth commissions, international criminal courts and police forces. She was the Acting Archivist of the United States, 1993-1995.

Marius Stan holds a PhD in political science from the University of Bucharest where he is now Research Director of the Hannah Arendt Center. He served as the editor of the journal History of Communism in Europe. $\mathrm{He}$ is the author of books published in several languages and of numerous articles in international scholarly journals. Most recently, he has coauthored together with Vladimir Tismaneanu Romania Confronts Its Communist Past: Democracy, Memory, and Moral Justice (Cambridge University Press, 2018), and previously A Stalin Dossier: The Genialissimo Generalissimo (Bucharest, Curtea Veche Publishing, 2014) and $A$ Lenin Dossier: The Magic of Nihilism (Bucharest, Curtea Veche Publishing, 2016). His research and teaching interests include 20th-century European Communism and fascism, revolutionary political ideologies and movements, transitional justice and the main intellectual biographies and debates during the Cold War.

Henri Thulliez is a member of the Paris Bar. He worked for Human Rights Watch between 2011 and 2016 as a coordinator on the Hissène Habré case. He was responsible, inter alia, for coordinating the legal and mediarelated activities of the various protagonists: associations, lawyers and victims of the regime. He headed the Foundation for Equality Opportunity in Africa, and is co-founder of the Platform to Protect Whistleblowers in Africa (PPLAAF). 
Vladimir Tismaneanu is Professor of Comparative Politics and Director of the Center for the Study of Post-Communist Societies at the University of Maryland, College Park. In 2006, he chaired the Presidential Commission for the Analysis of the Communist Dictatorship in Romania. In 2008-2009, he was a fellow at the Woodrow Wilson International Center for Scholars. His research areas include comparative politics, political ideologies, revolutions, as well as the contemporary politics of Central and Eastern Europe. His books include Romania Confronts Its Communist Past: Democracy, Memory, and Moral Justice, co-authored with Marius Stan (Cambridge University Press, 2018), The Devil in History: Communism, Fascism, and Some Lessons of the Twentieth Century, 2012; paperback 2014), Stalinism for All Seasons: A Political History of Romanian Communism (2003), Fantasies of Salvation: Democracy, Nationalism and Myth in Post-Communist Europe (Princeton University Press, 1998; paperback 2009) and Reinventing Politics: Eastern Europe from Stalin to Havel (Free Press/Simon \& Schuster, 1993). Tismaneanu is a member of the editorial board of the Journal of Democracy and the Journal of Cold War Studies.

Kirsten Weld is Professor of History at Harvard University. A scholar of modern Latin American studies, her research explores 20th-century struggles over inequality, justice, historical memory and social inclusion. Her first book, Paper Cadavers: The Archives of Dictatorship in Guatemala, won the 2015 WOLA-Duke Human Rights Book Award and the 2016 Best Book Award from the Latin American Studies Association's Recent History and Memory Section. She is currently writing her second book, Ruins and Glory: The Long Spanish Civil War in Latin America, which examines the impact and legacies of the Spanish Civil War in the Americas from the 1930s through the present. Her research and essays have appeared in venues such as Hispanic American Historical Review, Journal of Latin American Studies, Radical History Review, Plaza Pública, Dissent, Guernica, Modern American History and NACLA Report on the Americas.

Vincent de Wilde d'Estmael is Senior Assistant/Deputy International Prosecutor at the Extraordinary Chambers in the Courts of Cambodia (ECCC) since March 2007. He previously worked as a lawyer at the Brussels' Bar Association (1992-1995 and 2001-2002). In Rwanda, he was in charge of training programmes for legal personnel on behalf of the NGO RCN-Justice and Democracy (1995-1996), expert legal adviser to the Gikongoro Prosecution Office and, from 1996 to 1998, personal advisor of the Chief Prosecutor at the Supreme Court (for the UN Department of Social and Economic Affairs - UNDESA). From 1999 to 2001, he was Director of the Judicial Defenders Project of the Danish Institute of Human Rights, before heading a programme for the improvement of 
List of authors xvii

criminal justice and detention conditions in Cameroon financed under the European Development Fund and carried out by the British Council (PACDET, 2002-2005). Between 2005 and 2007, he was Deputy Head of the Rule of Law Section of the UNOCI peacekeeping mission in Ivory Coast, with responsibility for legal affairs. 


\section{Foreword}

I welcome the attention this book brings to the important task of archiving records of mass human rights violations. The careful documentation of atrocities is an essential step towards accountability for the perpetrators, justice and reparations for the victims and preventing further conflict by deterring and preventing future abuses.

Public access to archival information about serious violations of human rights and humanitarian law is also essential to ensuring the right to truth. I have witnessed the pain suffered by victims of serious human rights violations and their families. I know how painful it can be to search for - and find - the truth about what happened.

But acknowledgement by society that grave injustice was inflicted can bring a measure of consolation to families and contribute to the dignity of the survivors. Moreover, in the case of groups such as the Grandmothers de Plaza de Mayo, who search for the children of their detained parents and illegally adopted, there is another dimension: the search for truth may culminate in the joy of at last meeting their grandchildren. It also offers these grandchildren the ability to re-establish their true identity and lost family ties.

Victims - and everyone in society - have an inalienable right to know the truth about what has happened. They have a right to see that justice is done. All of these aspects are essential to reconciliation.

By establishing the guilt of individuals - not entire communities - trials can help to erase the perception that a whole community was collectively responsible for massacres - a view that may drive repeated cycles of violence. Justice also builds public confidence in the new, or renewed, institutions of the State.

These vital processes of justice can only take place when evidence has been gathered, organised and preserved for impartial assessment.

Complementing prosecutions, truth-telling initiatives also promote more objective public understanding of events that have taken place, because they allow conflicting parties to hear each other's grievances and suffering. This development of a common understanding of what has happened is the basis of reconciliation. And over the longer term, archiving this work by truth 
commissions, and other truth-seeking initiatives, does not only guarantee the preservation of testimonies - whether by victims or perpetrators. It also builds an enduring educational tool to combat denial and revisionism.

As Archbishop Desmond Tutu has said, "Where justice and order are not restored, there can be no healing, leaving violence and hatred ticking like a bomb in the corner". A society that cannot access and discuss information about the crimes, which have occurred in its past, is deprived of a clear understanding of its own history and the complexity of its heritage. And when communities remain frozen in bitterness and mutual misunderstanding, this jeopardises the ability to build enduring peace and resilient and inclusive development.

Many post-authoritarian and post-conflict societies face great challenges in preserving, and enabling access to, records of mass violations. These challenges may stem from political reluctance to ensure clarity about these crimes; or they may stem from capacity considerations; or from long-standing denials of academic freedoms and the right to freedoms of information, expression and opinion.

In order to facilitate accountability, the United Nations is also active in collecting and preserving archives and records relevant to serious violations of human rights. Recent years have seen intensive efforts to collect, compile and analyse material, from all available sources, on atrocities in Syria and Myanmar. We in the United Nations stand ready to share our expertise in this vital area with States having need of it.

Archives of human rights violations are not only a tool for looking backwards. They help build society's future. To break the cycles of violence, bitterness, grievance and renewed violations, we must seek to rebuild more inclusive societies, where diversity - whether ethnic, racial, religious, political or communal - is recognised as valuable and is respected: where objective clarity about the past can advance a future of healing, in which recourse to violations is not only unacceptable but unthinkable. And where members of every community can work together to address the many facets of a legacy of divisions and violence; develop working relationships in the present; and thus build the beginnings of a shared vision of living, peacefully, together.

Michelle Bachelet UN High Commissioner for Human Rights 


\section{Message from the President of the International Council on Archives}

The principal motivation for the collective efforts of the Branches, Sections, Expert Groups and volunteers of the International Council on Archives (ICA) is the fundamental and enduring value of archives. As proclaimed on our website, the ICA membership is united by the belief that

archives constitute the memory of nations and societies, shape their identity, and are a cornerstone of the information society. By providing evidence of human actions and transactions, archives support administration and underlie the rights of individuals, organisations and states. By guaranteeing citizens' rights of access to official information and to knowledge of their history, archives are fundamental to identity, democracy, accountability and good governance.

It is fitting therefore that ICA should commit itself to developing the role of archives in the support of human rights, and as the peak international authority on archives, it should step up and provide leadership in both policy and practice in this area. In my view, this is a priority not only because of the importance of human rights, but also because of the complexities that confront archivists when dealing with human rights in a constantly changing societal context.

The International Bill of Rights describes human rights as a set of principles expressing rights of liberty, equality and justice and freedom of opinion, without distinction of any kind arising from race, colour, sex, language, religion, political or other opinion, ethnicity, property, birth or other status. These principles are enduring, however their practical application is constantly evolving in complex and non-obvious ways.

The realisation of human rights in a modern pluralistic society requires a balance: a social contract with a certain degree of negotiation and compromise. Finding the right balance can at times be challenging for lawmakers, judiciaries and civil society. They can compete with one another; for example the achievement of collective security may come at the expense of personal privacy. The practice of a right to freely express personal opinions may result in degrading treatment inflicted upon marginalised communities. 
As our societies evolve, our appreciation of human rights must also continue to evolve. In recent years, worldwide movements, such as Occupy, MeToo and Black Lives Matter, and the resurgence of indigenous beliefs and cultures while traditional collective ownership systems are endangered by "progress" have mobilised people all over the world to join public actions in the name of social and economic equality. Other movements have singled out issues such as corruption, global warming, domestic violence and extremism as challenges that must be faced on the basis that they deny people their basic human rights.

It is inescapable. Every day the news bulletins across the globe reinforce the message that the recognition of human rights has never been more important to people everywhere.

I would argue, however, that these new frontiers of the human rights debate cannot be properly settled unless we are able to deal with the most serious transgressions of human rights in our immediate and recent past, inflicted upon people during times of war or by past oppressive regimes. Many of these darker chapters of humanity's history are explored as case studies in this publication. These case studies show that even in cases of large-scale and widely acknowledged injustices, the path to justice and the restoration of rights is complex. The achievement of truth and reconciliation cannot be taken for granted or underestimated.

As already stated, ICA recognises that archives contain the evidence upon which the defence of human rights can be prosecuted. The role of the archivist therefore is vital. All archivists should understand how, while acting within legal and regulatory frameworks, we can contribute to the development of societies that are just, inclusive and egalitarian. As archivists, we should ensure that archives exist as authentic evidence of administrative, cultural and intellectual activities; and moreover that this invaluable resource will continue to advance a rights-based society for all.

This landmark publication, produced by the ICA Section on Archives and Human Rights, is an invaluable reference to inform our thinking in these important areas. As President of the ICA, I congratulate the contributors and editorial team and commend it as essential reading for all of us with a commitment to the recognition of human rights. 
$\because$ Taylor \& Francis Taylor \& Francis Group http://taylorandfrancis.com 


\title{
Introduction
}

\author{
Jens Boel, Perrine Canavaggio and \\ Antonio González Quintana
}

Sources to all features of the history of humanity can be found in the archives. Records reflect multiple aspects of the life of societies and of each individual, from birth to death. In this book, our focus is on records as evidence of massive human rights violations, in particular crimes against humanity.

Painful memories haunt us like ghosts. They come to us from the ESMA torture centre in Buenos Aires, from beyond the silent surface of Rio de la Plata and the depths of the Atlantic and the Pacific Oceans where opponents of military dictatorships in Latin America were dumped from the sky to their deaths and from all over the world where citizens are being persecuted, discriminated against, excluded and killed for what they believe in or simply for who they are. Recently, this is what happened in Cambodia, Rwanda, South Africa and Spain, today the nightmares continue in Myanmar, Syria, Yemen and elsewhere.

Anyone who has watched Claude Lanzman's documentary Shoah (1985) will recall how documents apparently as dry as dust, such as train timetables, can serve to reveal the inner core of evil, "the heart of darkness". The timetables do this by providing evidence of the transports towards death in Auschwitz and by revealing the mute efficiency of bureaucracy in smoothly implementing as many transports as possible in as little time as possible. The archives show the wheels of inhumanity: the horror.

Marek Halter wrote that memory may be our only living eternity. ${ }^{1}$ It is our capacity to deal with these memories that make us who we are. It is not only former repressive regimes, like Argentina, Chile, Germany, Japan, Portugal, Russia and a host of other countries, which face this challenge. Current ones, like China and Saudi Arabia, former colonial regimes, such as Belgium, France and the United Kingdom, and big democracies, like Canada and the United States, without a colonial past but with a track record of abuse of indigenous populations, are also concerned. In short, this is a truly universal phenomenon.

Documents and records may bring repressed memories back to life. While amnesty laws in countries like Argentina and Spain aimed at "turning the page" or sweeping the past under the carpet, recent developments in 


\section{Jens Boel, Perrine Canavaggio and Antonio González Quintana}

these countries and in many others have shown that regardless of how hard you try to push the unpleasant memories into a closet, lock it and throw away the key, they still come back to haunt you. Survivors and families and friends of victims will claim their right to truth and justice. This is why the bodies literally come out of the earth in Spain, when relentless efforts of associations and individuals result in the discovery of documents revealing the whereabouts of mass graves from the Franco years, and this is why the voices of the Grandmothers of the Plaza de Mayo could not be ignored indefinitely.

Coming to terms with its own history is also a way for a society to sustainably build peace. In the UNESCO Yamoussoukro Declaration on a Culture of Peace from $1989,{ }^{2}$ this was one of the essential insights. In fact, this perception was not really new, because it built upon the Preamble of UNESCO's Constitution from 1945, which stated that any lasting peace must be secured by "the defences of peace in the minds of men". What had changed over the years was mostly the awareness that conflicts and wars happen not merely between states but also within them, between different groups or communities of people. Searching for truth, justice and reconciliation is also a way of searching for peace, both among and within societies.

The painful chapters of the past often involve several countries, and the archival search therefore has to be international. One striking example is Operation Condor, a secret military intelligence operation carried out by six South American dictatorships, supported by the United States, between 1973 and 1980. During that time, between 15,000 and 30,000 opponents were tortured and/or murdered. In 1992, a former political prisoner in Paraguay, Martín Almada, got a tip which enabled him to discover 700,000 documents on Operation Condor, the "Terror Archives", in a run-down police station in the outskirts of Asunción. Later on, the National Security Archives in Washington, DC, obtained the declassification of thousands of CIA files, which also helped in shedding light on this state-organised hunt for left-leaning dissidents in South America and on their tragic fate. ${ }^{3}$ Archives in all the countries that participated in Operation Condor have provided pieces of the puzzle that can, finally, establish the truth about what happened to the victims - and about the perpetrators as well. In some countries, like Chile and, in particular, Argentina, perpetrators of human rights violations have been brought to justice. Archives have in these cases played a key role in ensuring fair and informed trials.

The 1990s were a decisive decade for the emergence, at the international level, of the principles of the right to the truth, justice and reparation. As we shall see in Part 1, these were the years where the United Nations adopted the Joinet Principles. It was also, in 1998, the period where a Spanish judge, Baltasar Garzón Real, with the help of Scotland Yard arrested the former Chilean dictator, Augusto Pinochet, in London for crimes committed as part of Operation Condor and documented by archival evidence. The symbolic significance of judge Garzón's legal action was tremendous; in multiple 
countries, sympathisers and families of victims gathered to express their joy and relief to see a glimmer of hope of justice prevailing in the end. Such is the power of the record.

What we witness during the 1990s and later is also a metamorphosis of the perception of the role of the archivist. While preservation of institutional memories remained essential for the archivist, facilitating access became much more important. What was really new was the idea that archivists could and should play an active role in defending basic human rights, in particular by enabling access to documentation on human rights violations. While archival documents traditionally were mostly considered for their administrative and heritage value, they now, more than before, entered the contemporary political and historical scene. Historical amnesia in educational systems was widely challenged and archives played a crucial role in that process. With the exponential growth of information which accompanies the development of the new information and communication technologies, in particular the Internet, the archives take on an even stronger role. In view of the very mixed trustworthiness of the ocean of available information, the qualities associated with archives - authenticity, verifiability become crucial. In an era marked by fake news and during which the Oxford Dictionaries (in 2016) declared the term "post-truth" to be the international word of the year, such qualities are more sought for than ever. What a transformation of the image of archivists since 1951 when the French National Archivist, Charles Braibant, summarised the common perception of members of the profession as "passive warehousemen of history" "!

This new awareness of the relevance and importance of archives in documenting violations of human rights is also reflected in the International Register of UNESCO's Memory of the World programme. Between 2003 and 2011, human rights documentation and archives from a number of countries, in particular in Latin America but also Cambodia, the Republic of Korea and South Africa, were included in the Register. These collections included the Archives of Terror, submitted by Paraguay and admitted in 2009. Argentina, Brazil, Chile and the Dominican Republic also ensured admission of human rights archives in the Memory of the World Register during these years. The process reflects the emergence of an awareness of the significance of these archives and memories, not only for the countries directly concerned but for humanity as a whole.

In some situations, political instrumentalisation and conflicting interpretations of tragic and terrible historical events have led to tensions among countries. This is, for example, the case as regards the Nanjing massacre (1937-1938). In Part 2, Chapter 6, Karl Gustafsson analyses this particular aspect of Sino-Japanese relations, which has led to a major crisis for the UNESCO Memory of the World programme. As Gustafsson demonstrates, even in such complicated situations, there are ways forward towards enabling nations and peoples to come to terms with their histories and, here again, archives play a vital role. 


\section{Jens Boel, Perrine Canavaggio and Antonio González Quintana}

A wave of historical documentaries and films on cases of human right violations emerged in the early 21st century. Many of them built on archives or focused on archives as a tool to understand and come to terms with traumatic parts of the past. In Latin America, the wave has been, and still is, particularly strong and intimately connected with the violent, recent past of most of these countries. La Isla-Archives of a Tragedy (2009) is one striking example; this documentary tells the story of repression in Guatemala from 1954 to 1996 through the archives of the secret police. ${ }^{5}$ The importance of forensic and archival evidence in fighting against the impunity of senior military officials and intellectual authors of the genocide in Guatemala (more than 200,000 victims) is documented in the film Granito: How to Nail a Dictator (2011). Los archivos del cardenal (The Archives of the Cardinal) is a Chilean television series from 2011, based on the human rights defence work carried out by the Vicariate of Solidarity during the Pinochet dictatorship (1973-1990). Also in Chile, Sebastián Moreno's film La ciudad de los fotógrafos (2006) documents an independent movement of photographers in the 1980s, which helped in making people aware of the atrocious crimes committed by the regime.

Some of these films became popular successes with excellent reviews, awards and high audience numbers - for example, Das Leben der Anderen (The Lives of Others) from 2006, in which the Stasi archives provide their bitter-sweet, ambiguous truths. Rithy Panh's documentary S21: The Khmer Rouge Death Machine from 2003 reached a wide audience and made a huge impression. More recently, from 2018, El Silencio de Otros (The Silence of Others) is a powerful warning against forgetting the victims and the atrocities committed by the Franco regime in Spain.

Documentaries and films about massive violations of human rights also played a significant role much earlier. A particularly significant example is the documentary The Sorrow and the Pity (French original title: Le Chagrin et la Pitié) from 1969 about the collaboration between the Vichy Government and Nazi Germany during the Second World War, a film that was not shown on French television until 1981, although it had initially been commissioned by a government-run TV station. The documentary was censored because it, as the television director put it, "destroys myths that the people of France still need". 6

In the literary field, the late 20th and early 21st centuries have witnessed a strongly increased interest in the search for memories of crimes against humanity. A few examples of influential non-fiction works are The File by Timothy Garton Ash from 1997, where his consultation of Stasi records enables him to identify and meet the agents and informers who had watched over him, and The Lost: A Search for Six of Six Million from 2006 by Daniel Mendelsohn, which is an attempt to reconstruct the lives and deaths of six Jews trapped in a Polish town under Nazi occupation. In the field of fiction, no contemporary writer has probably been more influential when it comes to evoking painful memories than W.G. Sebald, who saw himself as 
a "ghost hunter" chasing "the conspiracy of silence". ${ }^{7}$ By way of a hypnotically intense and dense writing style, where every single sign matters, Sebald makes us, his readers, sense the immensity of the loss and horror of the Holocaust, more through oblique images and silences than by direct references. ${ }^{8}$

From the perspective of the editors of this book, the main purpose of efforts to keep - and, in some cases, restore - memory is to serve human rights of individuals and societies. These individuals can be relatives of disappeared, tortured or murdered persons. Getting to know the truth of what actually happened can bring some relief, in spite of the pain associated with confronting these facts and events. Societies need to be aware of the truths of history in order to overcome the horrors of the past and move on. In Latin America and elsewhere, the mantra of many associations of relatives of victims and in defence of human rights has been Nunca Más" - "Never Again". This reflects an urge for truth and justice involving, at its core, the fight against impunity. One final outcome may be reconciliation, as part of a process of building just and peaceful societies, but this can only happen on the basis of dealing honestly with the past. The sensitivity and approach are different from the situation in South Africa, where emphasis is on truth and reconciliation. The chapters of this book will show how the interaction between these different elements - truth, justice, fight against impunity, peace, reconciliation - has played out in various societies and cultures and in specific historical contexts.

Confronting memory is a way of making the ghosts disappear and begin building a brighter, more serene future. When Emmanuel Macron in February 2017 (at the time he was still just a French presidential candidate) during a visit in Algeria called colonialism "barbarian" and " $a$ crime against humanity", then this was indeed his intended purpose. In the United States, there have been voices addressing the topic of the country's long-standing support to right-wing military dictatorships in Latin America. President Clinton apologised in 1999 for U.S. support of rightwing governments in Guatemala that killed tens of thousands of rebels and Mayan Indians in a 36-year Civil War. It is worth noting that the apologies were offered on the basis of the report of a truth commission, the Historical Clarification Commission, which confirmed the CIA's participation in a war that killed more than 200,000 people. ${ }^{10}$ Although it must be emphasised that such apologies and recognitions are very often only partial (Clinton's apology to Guatemala was something of an exception), it is still worth noting that on the subject of the role of the United States in bringing to power and supporting the regime in Chile, Secretary of State, Colin Powell, declared in 2003: "It is not a part of American history that we are proud of". ${ }^{11}$ This is exactly the point: history cannot be reduced to patriotic celebrations. The healing begins with the acknowledgement that painful chapters are essential parts of history; archives then play a crucial role by providing evidence, thereby enabling scholars and citizens to get closer to the truth. 
However, this process is not "a long quiet river" towards truth and justice. The temptation to rewrite history for political purposes is irresistible for governments in some countries. In Poland, the current government is pushing a populist interpretation of contemporary history through the educational system and in museums and other cultural institutions. This means leaving out unpleasant parts, for example, on antisemitism. As The Guardian observed with respect to Poland: "Populists treat the past like fast food: they go straight for what's tasty and comforting for them, leaving aside the bits that might be healthier and more nutritious for all". ${ }^{12}$ Even more telling, perhaps, is the case of Brazil. With the intention of addressing the tough issue of human rights violations during the dictatorship following the military coup in 1964, Brazil proposed, and succeeded in 2011 in obtaining, inclusion of relevant archives in the Register of the Memory of the World. ${ }^{13}$ With the election, in 2018, of the former army captain, Jair Bolsonaro, as President of Brazil, the government works actively to transform the historical narratives of the military dictatorship to that of a glorious period of patriotic anti-communism. One of the climaxes of this revisionist movement was when Bolsonaro decided to organise commemorations to celebrate the 1964 coup. A journalist, whose brother was tortured and killed in custody and whose mother was also killed during the dictatorship, tweeted: "Brazil celebrating the anniversary of the ' 64 coup is like Germany instituting Hitler Day". ${ }^{14}$

Similar developments can be seen in other countries, like Hungary, India and Russia. These backlashes for the struggle for the right to truth, and, thereby, for evidence- and archives-based approaches, are reminders that human rights, such as the right to know and the right to justice, are not given once and for all after they have been achieved but have to be defended and constructed again, by every new generation. These political developments also demonstrate that the principles and ideals of the right to history and the right to the truth are universal; all countries are concerned and intertwined. The United Nations play a particularly important role in this context, as the UN High Commissioner for Human Rights, Michelle Bachelet, points out in her Foreword to this book. The writing of history has always been a battlefield, but only archives can ensure that the historical debate can take place on an informed basis.

In addressing the vast topic of this book, we have chosen to include case studies from all regions of the world. The authors come from different horizons and include archivists, lawyers, political scientists and historians. Our goal has been to cover a wide spectrum of questions and discussions, in particular relating to the use of archives in different contexts. Our starting point was the observation that huge and unprecedented amounts of police and security records, left by former repressive regimes, present new challenges in terms of preservation and access. Archives of NGOs constitute in some cases valuable, but also vulnerable, alternative or complementary sources. Truth and reconciliation processes in numerous countries lead to 
innovative and significant ways of using archives, including for educational purposes.

We hope the book will prove useful and inspiring for students and scholars of social and human sciences, individuals and associations involved in truth and reconciliation processes and the interested general public.

All authors have been invited to present briefly the historical, political, social and cultural contexts of their case. In particular, we have encouraged descriptions and uses of archives in national judicial processes, for Truth and Reconciliation Commissions and for transitional justice in general. We have also emphasised our interest in political processes (such as vetting), transnational relations, reparations, memory-building, education, research and prevention. The problems encountered with regard to uses of these archives relate to topics such as the political processes, identification, conservation, access, organization, manipulations and falsifications.

Our focus has been on cases from recent history after World War II. The selected cases provide an outlook and understanding, which is very far from being comprehensive in scope. Nevertheless, we believe that the diversity of our selection will enable the reader to get an overview of the types of questions and issues at stake when using archives to document massive human rights violations. If the book can serve as a tool and as an inspiration for future endeavours to use archives in defence of human rights, then we will have achieved our objective.

\section{Notes}

1 See Halter, Marek. 1995, La force du bien. Paris: Editions Robert Laffont, p. 8.

2 Yamoussoukro Declaration on Peace in the Minds of Men. 1989. Available at https://unesdoc.unesco.org/ark:/48223/pf0000090471.

3 On Operation Condor, see: Dinges, John. 2005, The Condor Years: How Pinochet and His Allies Brought Terrorism to Three Continents. New York: New Press.

4 Braibant, Charles. 1951, "Archivum," Archivum, vol. 1, pp. 3-4. See also: Rothschild, Emma. 2008, "The Archives of Universal History," Journal of World History, vol. 19, no. 3, pp. 375-401.

5 Kirsten Weld tells and discusses the story of the tumultuous existence of these archives in Part 2, Chapter 17.

6 Jeffries, Stuart. 2004, “A Nation Shamed," The Guardian, 23 January.

7 Schwartz, Lynne Sharon, ed. 2007, The Emergence of Memory: Conversations with W.G. Sebald. New York: Seven Stories Press.

8 W.G. Sebald writes most directly about repressed Holocaust memories in Austerlitz, published by Penguin Books in 2001.

9 The phrase was originally used as the name for the final report of the Argentine Comisión Nacional sobre la Desaparición de Personas (National Commission on the Disappearance of Persons - CONADEP). Available at www.desaparecidos. org/nuncamas/web/english/library/nevagain/nevagain_000.htm.

10 Available at www.nytimes.com/1999/03/11/world/clinton-offers-his-apologiesto-guatemala.html.

11 Kornbluh, Peter. 2003, The Pinochet File: A Declassified Dossier on Atrocity and Accountability. New York: New Press, p. XI. 
8 Jens Boel, Perrine Canavaggio and Antonio González Quintana

12 The Guardian, 17 September 2019: The populist rewriting of Polish history is a warning to us all.

13 Network of information and counter-information on the military regime in Brazil (1964-1985). UNESCO, Memory of the World: International Register. Available at https://en.unesco.org/programme/mow/register.

14 The Guardian, 27 March 2019: Fury as Bolsonaro orders Brazil army to mark 55 th anniversary of military coup. 


\section{Part 1}

\section{Archives and human rights}

A close relationship

Jens Boel, Perrine Canavaggio and Antonio

González Quintana 
$\because$ Taylor \& Francis Taylor \& Francis Group http://taylorandfrancis.com 


\section{Archives and citizens' rights}

\section{Human rights and public archives: a parallel history}

Democracy, human rights and archives have a shared history. As Michel Duchein (1983) notes in his historical analysis of the development of access to archives:

As far as is known, access to the archive repositories constituted by kings and priests in ancient times was limited strictly to the officials responsible for their preservation or to those who had received specific permission from the supreme authority. Actually, the preservation of archives has always been linked to the exercise of power, since the possession of memory is essential to governing and administering. Accessibility to archives was therefore a privilege, not a right . . . it seems that the idea of opening archives to non-official researchers is closely linked to the birth of the idea of democracy, that is to the Athens of the fourth century B.C. Litigants at law were permitted to seek documents in official archives to support their cases. Likewise, when elected magistrates were accused of treason or of violating the laws, the conservator of the archives was called upon to furnish the documents relating to the matter.

Looking back for early precursors of the concept of human rights, two examples that immediately spring to mind are the Magna Carta (1215), a charter of rights signed by King John I of England under pressure from rebel barons, and the Bill of Rights (1689), a landmark Act that was the culmination of the "Glorious Revolution" in 17th-century England. But we have to wait until the 18th century and the American Revolution to find the first real precursors of the Universal Declaration of Human Rights that is our benchmark today. While the Magna Carta and the Bill of Rights may have successfully clipped the monarch's wings, the rights they afforded were not general in nature and had only very limited scope. In addition, these rights were reserved for the privileged few, and bore a strong resemblance 


\section{Archives and citizens' rights}

to feudal systems such as pre-Revolutionary France (Ancien Régime) with its three estates.

The idea that access to archives was part of democracy was given a new lease of life with the philosophers of the Age of Enlightenment, at the same time as the notion that justice should be "transparent", and particularly that defendants should have access to the evidence of their accusers, as most famously stated by Cesare Beccaria in Dei delitti e delle pene (On Crimes and Punishments), 1764. This was the first departure from the principle of absolute secrecy of judicial archives that had been inherited from Roman criminal procedure.

The Virginia Declaration of Rights of 1776, which was to have a decisive influence on the U.S. Declaration of Independence of the same year, the 1789 U.S. Constitution and, to an even greater extent, the 1791 U.S. Bill of Rights, without doubt recognised some of the rights that would subsequently feature in later, more recent declarations of rights, for example the unalienable right to life, liberty, ownership of property, safety, the pursuit of happiness and freedom of speech, to which may be added the right of resistance or rebellion against injustice. While, on the surface, the words used in these documents may seem universal, in truth this was far from the case, because none of the rights listed in the Virginia Declaration, the Declaration of Independence or the U.S. Bill of Rights extended to women and slaves. ${ }^{1}$

Perhaps the most direct predecessor of later declarations is the Declaration of the Rights of Man and of the Citizen (Déclaration des droits de l'homme et du citoyen) adopted in France in 1789 by the National Constituent Assembly, which was the first actually to include the words "rights of man" in its title. Its Article 15 also states that "The society has the right of requesting an account from any public agent of its administration". And it was soon after this declaration, in the early days of the French Revolution, that the first law was passed establishing a new National Archives to be open to all French citizens (7 Messidor Year II, i.e. 25 June 1794). There are a number of authors who believe that it was not historical research that motivated the French revolutionaries but more the "desire to use the National Archives to preserve old records as nationalised public property" (Cunningham, 2005). Nevertheless, the proclamation that "the archives belonging to the Nation, including governmental, administrative, judiciary and ecclesiastical archives, were to be accessible freely and without cost to all 'citizens' requesting such services" was truly historical (Duchein, 1983).

From the time of the 19th-century liberal revolutions, Archives set about adapting their structures and regulations to cater to requests from citizens demanding application of their newfound rights, not least the right to personal identity, as a step towards acquiring the citizenship promised by the French Civil Code and documented through Civil Registration. Property rights, for their part, were guaranteed through the Land Registration system. Subsequently, the legal safeguards protecting citizens' rights were 
further bolstered by the recordkeeping systems that emerged in waves on a parallel to the fledgling liberal democracies and fundamental freedoms.

The civil registration system created in 1792 was to have an even greater effect than the National Archives in consolidating the rights laid out in the 1791 French Constitution through the inclusion in its preamble of the principles outlined in the Declaration of the Rights of Man and of the Citizen. It was at this point that convergence between universal rights and archives reached its zenith. Civil registries were set up in each of the different municipalities, a principle extended under Napoleon to the rest of the Empire, for purposes of enforcing the Civil Code. The secular State supplanted the Church, which previously had a monopoly over public records: births, marriages and deaths and their respective registries. Until then, it was the parishes that kept sacramental records of births and marriages in line with the decisions of the 1563 Council of Trent. Previously and until the Revolution, it had been impossible to register the birth of anyone who was not a churchgoer or who had not been baptised:

The purpose of introducing civil as opposed to religious rites was to show that, in declaring their vital details to the municipal registrar, individuals could become members of the community of citizens in the same way as baptism signalled their entry into the community of Christ. . . . Babies were to be "presented" by their parents to the "secular" church, in other words the "house of the community" (town hall). These principles then formed the basis for addressing the actual issue of individual identification. $^{2}$

(Noiriel, 1993)

Since civil registration came into force civil rights and public records and archives have evolved along parallel lines. Civil registration, as a secular system linked to the public authorities, may rightfully be considered the ancestor of public archives. This is the moment in history to which we can therefore trace back the earliest links between archives and individual liberties and, later, between archives and democracy.

These parallels speak for themselves in Haiti, for example, where the first Constitution, in 1801, explicitly stated that all men were equal, irrespective of their colour and that no men should be slaves. This was the first ever text to grant the same rights to blacks and whites, which was fully concordant with the terms of earlier declarations but totally at odds with the realities of the situation in the United States and, at certain moments of its history, in France. The 1801 Constitution was the brainchild of the Island's Governor General, Toussaint Louverture, at a time when Haiti was still a French colony. The Constitution was short-lived, because it was rescinded by Napoleon the following year, after slavery, previously abolished by the National Convention in February 1794, had been restored. In this West Indian island, the scene of the first triumphant slave uprising, civil registration was of 
enormous importance and, for historical reasons connected with the large number of Haitians who have emigrated over the past 200 years, it has always been a vital aspect of Haitian life and a constant cause for concern. Oddly, in one of the first countries to adopt civil registration, it was here that it was to be eroded over the years. With such a huge emigrant population, many people have had to fight to secure recognition of their personal identity. The crucial moment in this highly explosive situation came when fighting broke out in the Dominican Republic in response to the decision to deregister Haitian children born there with retroactive effect (IACHR, 2015; Primera, 2013). From the time the National Archives was created in Haiti in 1860, it was linked to the civil registry, with the result that, by the last third of the 20th century, it was little more than a satellite of the registry. It is no coincidence that the oldest documentary holdings in Haiti's National Archives are civil registers dating back to 1799 (Bertrand, 1988).

The second major source of documentary material connected with the rights laid out in the Declaration of the Rights of Man and of the Citizen and their application is the property registers held by the Land Registries which have the status of official agencies open to the public.

\section{The making of international human rights law and the right to access archives}

If we were to try to pinpoint the moment in international law when international tribunals first became able to judge crimes against humanity, we would naturally think of the International Military Tribunal (IMT) convened in Nuremberg in 1945 and, equally, of the International Military Tribunal for the Far East (IMTFE) convened in Tokyo following the capitulation of Japan, the sessions of which ran from 3 August 1946 to 12 November 1948.

While Nuremberg and Tokyo are most remembered for the sentences passed on the main leaders of the Third Reich and Japan, respectively (with the exception of Emperor Hirohito), perhaps the most remarkable development was that a number of concepts soon to become key features of international law, not least that of "crimes against humanity", were given theoretical definitions. These concepts were also included among the socalled Nuremberg Principles and set out in the Charter of the International Military Tribunal in Nuremberg (Nuremberg Charter) on 6 October 1945. They set the foundations giving both tribunals authority to judge:

a Crimes against peace: namely, planning, preparation, initiation or waging of a war of aggression or a war in violation of international treaties, agreements or assurances, or participation in a common plan or conspiracy for the accomplishment of any of the foregoing;

b War crimes: namely, violations of the laws or customs of war. Such violations shall include, but not be limited to, murder, ill-treatment or deportation to slave labour or for any other purpose of civilian population 
of or in occupied territory, murder or ill-treatment of prisoners of war or persons on the seas, killing of hostages, plunder of public or private property, wanton destruction of cities, towns or villages, or devastation not justified by military necessity;

c Crimes against humanity: namely, murder, extermination, enslavement, deportation and other inhumane acts committed against any civilian population, before or during the war, or persecutions on political, racial or religious grounds in execution of or in connection with any crime within the jurisdiction of the Tribunal, whether or not in violation of the domestic law of the country where perpetrated.

However, while the intention was clearly to punish these crimes, the new and emerging laws contained major loopholes which cast doubt on their legitimacy, not least the fact that they offered impunity to the authors of crimes committed by the Allies, even when these crimes fell perfectly well into the new categories defined. The most blatant examples were the bombing of civilian populations and, more especially, the dropping of atomic bombs on Hiroshima and Nagasaki (Bassiouni, 1999, p. 553). Other such examples include the Katyn Forest massacre, a crime that the Soviet judge at the International Military Tribunal tried, with staggering hypocrisy, to blame on the accused in the dock, even though the murder of Polish army officers was ordered by the Soviet Army, as was to emerge later in the course of events (Sanford, 2005). This approach to impunity was dictated by a number of political decisions made by Heads of State and political leaders in the immediate post-war context.

The horror of the extremely violent attacks on individuals in the troubled years of the first half of the 20th century, among them the extermination of civilian populations, genocide, deportation and war crimes, including the Holocaust and other unspeakable crimes perpetrated by the Nazis, culminated in the aftermath of World War II in the decision to create new international legislation based on the Nuremberg Principles to form the legal reference framework for prosecuting the war criminals of the Axis powers. This, in turn, led to the approval in 1948 by the UN General Assembly of the Universal Declaration of Human Rights and the Convention on the Prevention and Punishment of the Crime of Genocide. It was also in 1948 that, under the aegis of UNESCO, the International Council of Archives (ICA) was set up in Paris as a non-governmental organization tasked with promoting international cooperation, research and development in all archiverelated fields and with contributing to the development and application of UNESCO's archival and recordkeeping programme.

Each of us could easily draw up a detailed list of all the economic and personal aspects of our daily lives where, without documentary evidence, we would be unable to exercise our rights (Peterson, 2018). In addition, the loss or absence of official records or archives can have tragic consequences. By way of example, we need to only think of the importance of the civil 
registry of births for defending children's rights. Reverting to the issue of civil registration, it is not by chance that, for the United Nations, one of the basic challenges consists of ensuring that no child should exist without an officially established identity. Only $73 \%$ of children aged under 5 have their birth registered, a figure that falls to $46 \%$ for Africa. It is for this reason that the UN Sustainable Development Goals include the target of providing legal identity for all, including birth registration. ${ }^{3}$ And if we consider justice and the efficiency of the courts of law and the need to be able to rely on wellmanaged archives and records or if we think of the quality of public services designed to protect our economic and social rights, we can see just how closely rights and records are related. Archives are therefore a vital aspect of public service, as evidenced by the extent to which our health systems are dependent on well-managed hospital records (IGA, 2016).

However, it was many years before the Universal Declaration of Human Rights was translated into applicable international law. It was only on 16 December 1966 that the International Convention on Civil and Political Rights (ICCPR) was adopted by the UN General Assembly under Resolution $2200 \mathrm{~A}$ (XXI), the covenant only coming into force on 23 March 1976. For its part, the International Convention on Economic, Social and Cultural Rights also adopted by the UN General Assembly on 16 December 1966 finally became effective on 3 January 1976. Throughout the Cold War period, universally recognised rights were put on the international backburner, for want of endorsement via the normal international legal channels, even though they had been included in a large number of national constitutions, which afforded them the protection of national legislation.

To a large extent, archives followed a similar pattern. The International Council on Archives and most major archival institutions around the world devoted their attention mainly to promoting the historical research function of their holdings.

Things began to change in the 1970s with the fall of the dictatorships in Greece, Portugal and Spain, Western Europe's last three remaining totalitarian states. The decisive breakthrough came with the demise of a number of Latin American dictatorships in the 1980s and the collapse of most of the Communist regimes in the 1990s. It was the end of apartheid in South Africa and the start of peace processes marred by long and bloody Civil Wars in Africa, Asia and the Americas in the last third of the 20th century that marked the high point of a huge wave of democratisation and the beginning of the many and various transitional processes in the countries concerned.

The collapse of these dictatorships also signalled the disappearance of their police and intelligence services and the special forces engaged in political repression. It saw the demise of a number of other administrative and political agencies linked with the now defunct regimes. The documentary heritage all these services and organizations left behind represented huge volumes of information on the nature and scale of past repression. In countries going through the process of transition, coping with this material and 
deciding on how best to preserve and use it was a huge challenge for these fledgling societies. There was therefore a period, which can be roughly situated between 1974 and 1995, when the world of archives underwent major transformation, as the democratic wave continued to sweep across the world. It was then that archiving as a profession began to change rapidly, as the concept of archives and the role of archivists and record managers in society were called into question and rethought. It was also then that a number of new organizations began to take shape, alongside the national archiving systems, to manage and maintain all this documentary heritage. Even in countries where records inherited from the secret services of the former regimes were taken over by the National Archives, these latter found themselves faced with the need to experiment with new ways of fulfilling their public service functions to cater to the role these records were to play in providing reparation to the victims of repression and identifying those responsible for human rights violations under the old regime. These "new archives", the new laws and standards governing their use, the changing face of the profession and the proactive response of archival practitioners are all aspects that we shall be examining in detail in subsequent chapters.

It was during this period that the importance of public archives for the rights and duties of citizens in democratic societies was given a boost. Even in societies or organizations where records are not used for the purpose for which they were originally theoretically intended, the very fact of collecting and holding this material can have major symbolic significance. In archival circles, there is a very real sense that archives should not just be places where valuable old records are preserved but rather an administrative facility in which documents are processed and managed from production to either destruction or the decision to preserve them ad infinitum and to provide access. At the same time, concepts such as human rights, transitional justice, historical memory and transparency have been part of the staple diet of Archives and archivists since 1990 and have developed into areas where they now play a major role.

Another factor that gave added impetus to the radical transformation of archives and their extension to new services was the movement in favour of freedom of access to public information. The Freedom of Information Act passed in the United States in $1966^{4}$ signalled the start ${ }^{5}$ of the trend towards making administrative information publicly available in our societies by making accessibility the default setting for official documents, with some obvious, highly specific exceptions. While laws governing access to information have existed since 1766, it was only at the end of the last century and in the first decade of this century that a significant number of countries finally adopted legislation in this regard (Canavaggio, 2014). There are many reasons that may explain this phenomenon, but one of the most important is that

in countries that have recently made the transition to democracy, freedom of information laws allow governments to break with the past and allow society and the victims and their families of abuses to learn what 
happened and better understand. Almost all newly developed or modified constitutions include a right to access information from government bodies as a fundamental human or civil right.

(Banisar, 2006)

The demise of dictatorships and the long road towards democracy in transitional countries brought a further wave of demand directly or indirectly connected with the archives of the agencies involved in repression. Indirectly, in the sense that records may be temporarily or permanently necessary to ensure that justice is done and are essential to ensuring remembrance in our societies. Directly, because when their existence was common knowledge, as in the case of most central and eastern European countries that had communist regimes until the late 1980s, demand for release of these records was strong.

Accessibility of archives featured among the highlights of the wide-ranging social programmes that emerged in the Soviet Union and other communist countries after 1989. While this was, in part, the natural outcome of earlier developments, it was also a clear sign of the intentions of the new regimes, even if the effects took a while to cascade down, in some places more than others. Efforts to establish the truth about events in the recent past of these countries were generally one part of the political struggle to steer domestic affairs and international relations in a new direction.

All this reached its peak in the form of the recommendations for regulations to govern access rights to these archives produced by two international organizations. The first of these was the Council of Europe with its Recommendation No. R (2000)13 of the Committee of Ministers to Member States on European policy on access to archives (Kecskeméti and Székely, 2005) followed by Recommendation Rec (2002)2 of the Committee of Ministers to Member States on access to official documents. The first of these recommendations concerned archives, in other words, centres or institutions responsible for ensuring the long-term preservation of selected records, while the second concerned access to current records, documents in everyday use in official agencies, this being consistent with the laws on the right to access information mentioned earlier.

Basically, Recommendation Rec (2002) 2 urges Member States to guarantee universal access to official documents and considers that this principle should apply indiscriminately to nationals and non-nationals requesting such access. Recommendation R (2000) 13 also stipulates that access to public archives is an inherent part of their public service function and should therefore be free of charge. It also requires Member States of the Council of Europe to make provision in their legislation for all archives and records to be either unconditionally accessible to the public or should indicate the moment when this material will enter the public domain. This tallies with the principle agreed earlier by the International Council on Archives at its international Congress in Madrid in 1968, also known as the "30 year 
proposal". According to this principle, all records should ultimately be consigned to Archives (in the sense of historical records) and, therefore, be available for consultation 30 years later.

The 2000 Recommendation on access to archives was also important because of the ideas set out in its introduction which closes on an appeal to Member States to make this right a legal requirement:

Considering that archives constitute an essential and irreplaceable element of culture; Considering that they ensure the survival of human memory; Taking account of the increasing interest of the public for history, the institutional reforms currently under way in the new democracies and the exceptional scale of changes which are taking place in the creation of documents; Considering that a country does not become fully democratic until each one of its inhabitants has the possibility of knowing in an objective manner the elements of their history,

the Council of Europe recommends that "the governments of member states take all necessary measures and steps to adopt legislation on access to archives inspired by the principles outlined in this recommendation, or to bring existing legislation into line with the same principles".

The second international organization to tackle the subject of the right of access to official information was the Inter-American Commission on Human Rights (IACHR). In its Declaration of Principles of Freedom of Expression of 2000, it decreed that

every person has the right to access information about himself or herself or his/her assets expeditiously and not onerously, whether it be contained in databases or public or private registries, and if necessary to update it, correct it and/or amend it.

This is what is called "habeas data" in Latin America. It also states that

access to information held by the state is a fundamental right of every individual. States have the obligation to guarantee the full exercise of this right. This principle allows only exceptional limitations that must be previously established by law in case of a real and imminent danger that threatens national security in democratic societies.

In 1998, to coincide with the 50th anniversary of the Universal Declaration of Human Rights, the Commission recommended that Member States should introduce legislation and take all other relevant steps to officialise the right to open access to the information contained in official archives and records, in particular in cases where investigations in progress are geared towards establishing the responsibility of perpetrators of international crimes and major human rights violations. 
Starting with the first moves in North America, further shored up by the declarations of bodies such as the Council of Europe and the Inter-American Commission on Human Rights, legislation gradually began to take shape to guarantee freedom of access to information, often inspired by the reference documents and experience mentioned previously. ${ }^{6}$

In line with this trend, at its Congress in Brisbane in 2012, the International Council on Archives approved a series of principles with regard to access to archives. In all, it set out ten principles, each accompanied by explanations. Principles 1 and 6 relate directly to access to information in defence of human rights:

1 The public has the right of access to archives of public bodies. Both public and private entities should open their archives to the greatest extent possible.

6 Institutions holding archives [shall] ensure that victims of serious crimes under international law have access to archives that provide evidence needed to assert their human rights and to document violations of them, even if those archives are closed to the general public.

This introduction to the link between archives and freedom of access to information would not be complete without reference to the National Security Archive (NSA), a non-governmental organization set up in 1985 at George Washington University for purposes of encouraging access to official information using the possibilities offered by the Freedom of Information Act. From the many incoming requests for declassification of documents, the NSA has produced an impressive list of archives, many containing interesting information about interventions by the United States in countries ruled by dictators or governed by regimes known for their systematic violation of human rights. A good example is the work on Chile undertaken by Peter Kornbluh in 2003 in which he flagged up a whole series of documents from the CIA and the Department of State concerning the U.S. government's actions in Chile under Pinochet. Another example concerns the NSA's investigations with regard to Guatemala and the research carried out by Kate Doyle in 1999 on the documents garnered by the NSA in its enquiry into human rights violations in the country, these documents later being used in Guatemala and at the Inter-American Court of Human Rights to try the individuals accused of these crimes. 


\section{Records and archives documenting gross human rights violations}

\section{The United Nations in action: the right to know and the fight against impunity}

Over the last 30 years, the ever-growing struggle against impunity and the extension of global justice have spawned new individual and collective rights. Since the end of the Cold War, the United Nations has put international legal mechanisms in place to stamp out impunity. The international criminal tribunals set up for the former Yugoslavia in 1993 and for Rwanda in 1994 were major steps in this direction and were further underpinned in 1998 by the adoption by the United Nations of the founding treaty of the International Criminal Court, as a permanent body with universal jurisdiction for judging those accused of genocide, crimes against humanity, crimes of aggression and war crimes.

This development was followed in 2005 by the UN World Summit of Heads of State and Government, which decreed that States had a "responsibility to protect" 7 their own populations and the right to embark on international humanitarian action or to intervene in the event of an imminent threat of genocide or gross violations of human rights.

In the 1980s, self-amnesty laws began to proliferate in Latin America in the name of peace and reconciliation, for example in Chile, Argentina and Uruguay. But amnesty is often just a way of burying the past and forcing people to "forget" the crimes perpetrated, at the expense of victims and their families. There was a period during which, for reasons of pragmatism, these laws were considered a necessary evil, but all this changed following pressure from human rights NGOs and the introduction of mechanisms by the UN Commission on Human Rights to outlaw impunity. In 1992, the Inter-American Court of Human Rights issued the reminder that "the State has the obligation to use all the legal means at its disposal to combat impunity . . . , since impunity fosters chronic recidivism of human rights violations and total defencelessness of victims and their relatives". ${ }^{8}$

The World Conference on Human Rights held in Vienna in 1993 supported this line of thinking by adopting the text of a Declaration urging the United Nations to step up its efforts to combat impunity and a Programme 


\section{Gross human rights violations}

of Action. ${ }^{9}$ The UN Commission on Human Rights then appointed a French magistrate, Louis Joinet, to the post of Special Rapporteur on matters relating to the impunity of the violators of human rights. The aim was to seek "to strike an unattainable balance between the former oppressors' desire for everything to be forgotten and the victims' quest for justice" (Joinet, 1997, p. 3). His report formed part of the process of implementing the Vienna Programme of Action.

The report lists the three rights to which victims should be entitled: the right to know, the right to justice and the right to reparation. It also adds, as a precaution, a series of measures aimed at guaranteeing the non-recurrence of violations. The report concludes by listing a set of principles for the protection of human rights through action to combat impunity that are given in appendix to the main body of the report (Joinet, 1997, Annex II).

The right to know is a condition sine qua non for exercising the right to justice and reparation. It is therefore the first right mentioned together with four supporting general principles:

The first of these concerns the inalienable right to truth, which is not only an individual but also a collective right:

Every people has the inalienable right to know the truth about past events and about the circumstances and reasons which led, through systematic, gross violations of human rights, to the perpetration of heinous crimes. Full and effective exercise of the right to the truth is essential to avoid any recurrence of violations in the future.

The second principle follows on logically from and is the counterpart of the first and is the State's duty of remembrance:

A people's knowledge of the history of its oppression is part of its heritage and, as such, must be preserved by appropriate measures in fulfilment of the State's duty to remember. Such measures shall be aimed at preserving the collective memory from extinction and, in particular, at guarding against the development of revisionist and negationist arguments.

The third principle concerns the victims' right to know: "Irrespective of any legal proceedings, victims, their families and relatives have the imprescriptible right to know the truth about the circumstances in which violations took place and, in the event of death or disappearance, the victim's fate".

The fourth principle is entitled "guarantees to give effect to the right to know" and concerns action to be taken in cases where the judicial institutions are found wanting: establishing extra-judicial commissions of inquiry and ensuring the preservation of archives pertaining to human right violations. 
Principles 13-17 relate to the preservation of and access to these archives. ${ }^{10}$ Penalties are to be applied to prevent destruction or falsification of archives, especially if this is for the purpose of ensuring the impunity of the perpetrators of human rights violations. Access to archives must be facilitated for victims and their relatives to enable them to claim their rights and for those implicated who request it for their defence. The courts and extra-judicial commissions of inquiry must have free access to archives. Specific measures must be put in place to protect personal records. Major progress was achieved in 1998, when the Commission on Human Rights endorsed these Principles, ${ }^{11}$ because it was the first time that a UN agency officially recognised the link between archives and the battle against impunity. But these principles remain guidelines, which have no force in law. They are a reference framework, the purpose of which is to help States in introducing their own effective measures for combatting impunity. They have, however, been firmly endorsed by decisions reached in the international criminal courts and have been a contributory factor in progress made towards stamping out impunity.

At the request of the Commission, these Principles were revised in 2005 by Diane Orentlicher, a U.S. citizen and professor of international law (Orentlicher, 2005). The main modifications concerned the scope of the obligations befalling States under international law. The sections on archives are now numbered 14-18. A detailed commentary on the archival dimension of this subject may be found in a document co-authored by Valentina Cadelo and Trudy Peterson (2018).

The right of victims and their families to truth and reparation was formally recognised in the International Convention for the Protection of All Persons from Enforced Disappearance adopted by the UN General Assembly in 2006. ${ }^{12}$ The Convention opens by affirming "the right of any victim to know the truth about the circumstances of an enforced disappearance and the fate of the disappeared person, and the right to freedom to seek, receive and impart information to this end". This Convention is consistent with the proposals made by both Louis Joinet and Diane Orentlicher.

The notion of the right to the truth was originally mooted in the Organization of American States well before any of the major international organizations took up the cause. The Inter-American Commission on Human Rights (IACHR) was the first to raise the issue of the right to truth in so many words as one of the rights that States must guarantee for more effective application of human rights in accordance with the American Convention on Human Rights (Rodríguez, 2017).

The first time that the Inter-American Commission on Human Rights mentioned the subject of the right to truth was in 1986, in its 1985-1986 annual report. It stated, in particular, that every society has the inalienable right to know the truth about past events, as well as the motives and circumstances in which aberrant crimes came to be committed, in order to prevent repetition of such acts in the future. At the same time, nothing must prevent victims' families from knowing what happened to their relatives. 
The importance of archives in the quest for truth was clearly stated for the first time at the United Nations in 2005 by the Commission on Human Rights. In its resolution on the right to truth, the Commission made reference to the updated version of the Joinet principles in stating that it was

convinced that States should preserve archives and other evidence concerning gross violations of human rights and serious violations of international humanitarian law to facilitate knowledge of such violations, to investigate allegations and to provide victims with access to an effective remedy in accordance with international law. ${ }^{13}$

At the request of the Human Rights Council, ${ }^{14}$ the Office of the United Nations High Commissioner for Human Rights carried out a first study on the right to truth in $2006 .{ }^{15}$ This was the subject of an updated report in 2007, following consultations with the States and NGOs. ${ }^{16}$ Paragraphs 58-70 of the study address the need to preserve archives and make them accessible in view of their importance in ensuring that reparation can be made for damage suffered by victims and for prosecuting those responsible for the atrocities perpetrated. These archives have an intrinsic value directly linked to the exercise of victims' rights, the workings of the courts and non-judiciary mechanisms for establishing the facts, preserving memory and history. They may be used as evidence, especially for publicly rehabilitating people convicted on political grounds, the right of families to know the location of their vanished relatives, the right to amnesty of political prisoners and the right of victims to reparation and compensation. They also enable individual nations to exercise their right to the integrity of their written memory and the right of individual peoples to know the truth about their past.

In a second report on the right to truth dated 2009, the Office of the United Nations High Commissioner produced a more detailed description of the best practices for exercising this right, with almost half of the document concerning archival practices with regard to blatant human rights violations. ${ }^{17}$ The report recommends reinforcing the national archival system as a fundamental stage in any transition process. It also insists on the vital need for countries to enact laws on access to these archives. It describes the different ways in which archives can be used as part of transitional justice processes, both for purposes of prosecution and the right to justice and for efforts to discover the truth and the right to know. It gives details of the types of document that can prove useful and insists on the need to preserve the records of national or international transitional justice institutions, which are essential to the nation and its history.

In 2011, at the request of the Council, the Office of the High Commissioner organised a seminar attended by experts from NGOs and truth commissions, magistrates and archivists, who had the opportunity to describe the lessons to be learned from international experience. This was followed 
in 2012 by a resolution adopted by the Human Rights Council on the right to truth, which was endorsed by the UN General Assembly in 2013. This resolution

encourages States that have not yet done so to establish a national archival policy that ensures that all archives pertaining to human rights are preserved and protected and to enact legislation that declares that the documentary heritage of the nation is to be retained and preserved. ${ }^{18}$

In 2011, the Human Rights Council decided to mandate a Special Rapporteur to study developments with regard to the right to truth. ${ }^{19}$ To justify this decision, it referred, among other things, to the International Convention for the Protection of All Persons from Enforced Disappearance, Article 24, $\mathbb{S} 2$ of which recognises that all victims "have the right to know the truth regarding the circumstances of the enforced disappearance, the progress and results of the investigation and the fate of the disappeared person". It also states that "each State-Party has to take appropriate measures in this regard". In addition, the preamble to the Convention affirms the "right to freedom to seek, receive and impart information to this end".

In 2012, the Council appointed Colombian human rights expert Pablo de Greiff to be Special Rapporteur on the promotion of truth, justice, reparation and guarantees of non-recurrence, tasked principally with gathering

relevant information on national situations, including on normative frameworks, national practices and experiences, such as truth and reconciliation commissions and other mechanisms, relating to the promotion of truth, justice, reparation and guarantees of non-recurrence in addressing gross violations of human rights and serious violations of international humanitarian law, and to study trends, developments and challenges and to make recommendations thereon.

Two of Pablo de Greiff's annual reports specifically mention archives. His 2013 report to the General Assembly addressed the subject of truth commissions (de Greiff, 2013). In it, he expressed his conviction that setting up commissions and National Archives was an excellent means of ensuring the right to truth and emphasised the importance of archives as a bulwark against denial and revisionism.

In his report on Spain, published in 2014, de Greiff (2014) recounted the problems faced by the victims of repression in Spain in their attempts to discover the facts, referring to the existence of classified documents with no clear criteria for release into the public domain and, therefore, inaccessible sine die, in accordance with an outdated official secrets act passed in preConstitution days. He also flagged up disparities in archiving practices from one administration to another or from one section to the other of the same 
administration, contradictory and inadequate regulations on access and the lack of government-level legislation on archives.

It was, however, the report published by Pablo de Greiff in September 2015 that was to represent the second major development for the world of archives, in terms of references to archives and records in official documents produced by the United Nations in connection with the defence of human rights. In line with the instructions of the Human Rights Council, this report was supposed to follow up and expand on Louis Joinet's Set of Principles for Combatting Impunity. However, unlike the JoinetOrentlicher report, where the similarities with the recommendations of the International Council on Archives were not the result of concertation, in this instance the UN rapporteur had talked with archiving professionals and exchanged information with them. This point is clearly established in the report when it refers to the methods adopted and the contacts established for its compilation: In September 2014, the Special Rapporteur, the International Committee of the Red Cross and the organization Swisspeace organised in Geneva an expert workshop entitled "Archives in the Context of the Right to Know" (de Greiff, 2015).

In his report (paragraph C of Section VI, Interventions in the cultural and the individual spheres), de Greiff maintains that

archives containing records of mass violations can contribute to prevention. Access to well-preserved and protected archives is an educational tool against denial and revisionism, ensuring that future generations have access to primary sources, which is of direct relevance to history teaching.

He goes on to admit

a lack of consistency in the disposition of archives of transitional justice mechanisms, including truth commissions. To address this gap, as a first step and as a result of a series of consultations with experts, the Special Rapporteur developed a set of general recommendations that builds on the right to know.

These recommendations are given in an annex with the title "Set of general recommendations for truth commissions and archives".

This annex to the report ${ }^{20}$ contains recommendations on the archives produced by truth commissions. These recommendations are of vital importance because many of these documents are almost completely inaccessible and the solutions proposed for their management so dissimilar. Once societies, still marked by the traumas of the past, are finally ready to confront reality, they need to be able to consult these records, even following disbandment of the truth commissions. The annex also includes recommendations about the need for these commissions to consult records during their investigations. Archives must therefore be preserved and properly managed 
by qualified professionals. Pablo de Greiff issues a reminder in his report that archival systems and public records management policies should constitute two further objectives to be targeted in any process of political transition towards democracy. He therefore urges the commissions to recommend the development of national archiving policies and the introduction of modern legislation on archives, access to information and data protection. He also recommends that the authorities endow their national and local archives with the resources they need to be able to function correctly and develop comprehensive systems also protecting the archives of non-governmental organizations and business archives. Both can be vital in relation to violations.

In the 2017 report to the UN General Assembly, the focus was on prevention and included a passage on archives and records: "Access to wellpreserved and protected archives is an educational tool to combat denial and revisionism, as important for history education as for dimensions of institutional reform" ${ }^{21}$ This sentence was repeated in the 2018 report, submitted by Fabián Salvioli, the successor to Pablo de Greiff. ${ }^{22}$

In July 2020, Salvioli presented his report (2020) Memorialization Processes in the Context of Serious Violations of Human Rights and International Humanitarian Law: The Fifth Pillar of Transitional Justice. In this report, archives are considered a key matter for every memory process, in particular the question of access to archives. Among other important considerations on archives, the report includes the following recommendation:

in order for memorialization processes to be effective, it is essential to protect the archives of State agencies and civil society organizations, especially those that work in the area of human rights. Archives should be accessible in accordance with established standards, and Governments should remove obstacles to such access.

The Office of the High Commissioner also tasked Trudy Huskamp Peterson with conducting an in-depth study into the issue of archives and the right to truth. Her findings were published in 2015 under the title "Ruleof-law Tools for Post-conflict States". ${ }^{23}$ In this, she gives practical advice on managing and using archives in post-conflict states or those in the process of transition to democracy. She describes the type of documents required for investigation purposes and for vetting and expurgation and runs through the problems typically encountered. At the Office of the High Commissioner for Human Rights, archives are now established as one of the pillars of its efforts to re-establish the rule of law in countries in the process of transiting towards democracy.

\section{Archives of security services of former repressive regimes}

In countries long subjected to repressive regimes, where citizens were denied their most basic freedoms, and faced with the task of negotiating the transition towards democracy, the archives of the former State 
security services are a classic example of the importance of records for the new authorities and their citizens. Records that were formerly one of the main weapons in the armoury of repressive States for crushing all forms of political, religious, racial or ideological dissent have now become key elements under rule of law for repairing the damage suffered by the victims of repression and purging those responsible for the atrocities perpetrated. The scale of the tragedies reflected in these archives is beyond belief: millions of people who disappeared were incarcerated or interned in camps; hundreds of thousands of deportees and, among the victims of repression, close on 80 million deaths directly or indirectly attributable to this phenomenon in the 20th century according to Milton Leitenberg (2006), while Eric Hobsbawm (1995) puts the number of people who "died by human decision" in the 20th century at an estimated 187 million (Hobsbawm includes persons killed in wars).

Horrors in such proportions were bound, in all logic, to leave traces, even though, for obvious reasons, many records were hastily destroyed when those in charge of security and intelligence sensed the way the wind was blowing and took steps to erase all evidence of their acts. This is what happened in South Africa and in Rhodesia (González Quintana, 1997). Interestingly, the sheer volumes of records evidencing all the atrocities committed still represented one of the main challenges facing archivists. Archives were an essential $\operatorname{cog}$ in the state machinery in regimes based on systematic repression. All these regimes kept close tabs on their citizens by harvesting information about purported ideological opponents to their totalitarian or dictatorial policies, compiling endless reports, creating networks of informants and encouraging denunciation. Similarly, groups with particular ethnic or racial origins were identified and kept under close supervision under racist or segregationist regimes. With such tight controls, mass imprisonment and executions and major population movements would have been impossible without extensive infrastructures and logistics (prisons, concentration camps, supplies, transport, etc.) plus the troops and police to snuff out even the slightest suggestion of protest or social unrest. These regimes were also reliant on the existence of a complicated network of political and law enforcement agencies manned by hordes of civil servants and collaborators, in other words, repressive bureaucracy at its finest.

Huge volumes of archives were produced in connection with political repression in such regimes, the classic example being the 180 linear kilometres of records accumulated by the Stasi in the days of the former German Democratic Republic (GDR), to say nothing of the 174,000 officers and collaborators or the 40 million people or more on its records. All this material is now under the responsibility of the Federal Commissioner for the Records of the State Security Service (Stasi) in Berlin. And while we may not have precise figures, we can safely say that the records of the former Soviet KGB must have amounted to very similar volumes. Other extensive collections of records from repressive regimes may be found in Brazil, Spain and Portugal, 
etc. Last but not least, public archives in South Africa were flooded with documents from the "apartheid" administration.

These examples go to show how important archives are for repressive authoritarian regimes. From this we can draw a first conclusion, which is that records of this nature must have existed under all such regimes and, if not transferred to the new authorities during the transition process, probably still exist somewhere. Lost files may suddenly resurface quite by chance years later, as in the case of the archives of Alfredo Stroessner's political police in Paraguay. These contained the records for Operation Condor, a coordinated campaign of political terror mounted by dictatorships in countries in the Southern Cone (Argentina, Chile, Paraguay, Uruguay, Bolivia and Brazil), which were discovered in 1992, languishing in a repository in the suburbs of Asunción, by Martín Almada, a lawyer, human rights activist, former dissident and political prisoner. In Argentina, the archives of the Intelligence Service of the Police of Buenos Aires Province (Dirección de Inteligencia de la Policía de la provincia de Buenos Aires - DIPBA) owe their survival in 1998 to the unrelenting efforts of NGOs and, since 2000, have been held in safekeeping by the Buenos Aires Provincial Memory Commission. Yet, in 1983, the de facto President, General Reynaldo Bignone, personally gave the order that all the records held by the armed forces containing evidence of their acts should be destroyed. ${ }^{24}$ In Part 2, Chapter 16 by Mariana Nazar, there is a deep analysis of the Argentina's case. In Chad, the archives of President Hissène Habré's political police were discovered in 2001 by Human Rights Watch, ${ }^{25}$ as described in Henri Thulliez' case study in Part 2, Chapter 4. Another example is that of the historical archives of the Guatemalan National Police, more than 7 linear kilometres of material believed lost for ever, which came to light in an abandoned warehouse in 2005. Admittedly, the records kept by these regimes tended to be so voluminous that covertly destroying them was bound to be a major challenge, witness the attempts made to do away with Stasi records in Berlin between December 1989 and January 1990, which were thwarted by the population, and similar developments in Moscow with the Lubyanka archives on 24 August 1991.

The archives of the police and intelligence services, the so-called archives of terror, to use the name under which they are known in Latin America, are public archives. They consist, for the most part, of records and files on individuals under surveillance, duty logs, registers and witness statements at times extracted under torture, but they also contain records seized by the authorities during raids on suspect organizations and political opponents. To manage all these holdings, there would appear to have been two main approaches.

The first of these is typified by Germany, where a national authority has been made responsible for preserving the archives of the now defunct agencies, as shown in Part 2, Chapter 10 by Dagmar Hovestädt. Much the same approach has been adopted in other former communist countries in Central 
Europe. Because these authorities have a similar purpose and objective, some of them decided to join forces in setting up the European Network of Official Authorities in Charge of the Secret Police Files (European, 2014). ${ }^{26}$ The key feature of this approach is that files are used to ferret out those involved in the repressions of the past and disqualify them from holding any form of public office in the future (Lustration). Depending on the country, the national authority may take different forms. Poland and Slovakia have Institutes of National Remembrance, Germany has a Federal Commissioner, Hungary has a Central Archives, the Czech Republic and Romania have Research Institutes or Centres and, last but not least, Bulgaria has a Committee. While the names may differ, these authorities all have essentially the same objectives.

Another feature of this approach is the development of specific legislation to govern the use to be made of these files and records. New institutions, such as Remembrance Centres or Archives, have emerged in other parts of the world and in countries, mainly in Latin America, that have managed to break free from right-wing totalitarian regimes or military dictatorships. These institutions were also set up for the purpose of managing the records of the police or State security services of former repressive regimes, for example the Buenos Aires Provincial Memory Commission, established to take charge of the records of the Province's Police and Intelligence Service, or the Commission for the Archives of the Struggle against Dictatorship in the State of Rio Grande do Sul in Brazil, set up to manage the records of the Department of Political and Social Order (DOPS). The fundamental difference between these cases and those of former communist countries lies in the size and scale of the documents held: while archives of Central and Eastern European countries are remarkable for their sheer volumes, those in Latin America tend to be thin on the ground.

The second approach consists of consigning the archives of the State security services of former repressive regimes to the National Archives. The best illustration of this approach is Portugal, where records were first commandeered by the Commissions responsible for winding up these services in the immediate aftermath of the 1974 Carnation Revolution, before being transferred to the National Archives to be used by the courts and in the expurgation process. Similar arrangements occurred in Brazil, where the records of the National Security Council, the General Investigations Commission (Comissão Geral de Investigações) and the National Information Service (Serviço Nacional de Informações) were transferred to the National Archives when President Lula da Silva was in office. ${ }^{27}$ Another example is that of Spain, where the archives of General Franco's Intelligence Services were initially consigned to the Civil War Section of the National Archives. Since then, the section has changed name and the archives have been put under the umbrella of the Historical Memory Documentation Centre, while still having the same administrative reporting channels and the same links to the Spanish National Archives (Sub-Directorate General of National 
Archives). The case of the records of Alfredo Stroessner's secret police ("La Técnica") in Paraguay, which came to light by chance in 1992 during legal proceedings, is rather unusual. They were taken in charge by Paraguay's Supreme Court, where they are still managed by the Human Rights Archive and Documentation Centre.

The historical archives of Guatemala's National Police (AHPN) are another interesting example. These were discovered completely by chance, which explains why they were initially placed under the responsibility of the authorities that located them, in other words, the Office of the Ombudsman (Procurador de derechos humanos), despite the fact that they were not in the Office's actual possession because they remained the property of the Ministry of the Interior. The courts had ruled that the PDH would simply be allowed to consult them and manage them for use in its enquiries. With the help of a number of non-governmental organizations and volunteers, the PDH team then set about the difficult task of recovering these documents for use in chasing the truth, punishing those guilty of human rights violations and providing due reparation for victims. The international aid would be extended even when these records were officially transferred to the General Archives of Central America (Archivo General de Centro América - AGCA) in 2009 as required by the legislation on National Archives in force in Guatemala (González Quintana, 2019a).

In practice, these records constitute a special case, the like of which cannot be found anywhere else in the world, for two reasons: the first being the government's patent disinterest in them and the second the fact that they were exclusively funded by grants from development aid agencies in different countries under the banner of the United Nations Development Programme (UNDP). While the Archives remained answerable administratively to the Ministry of Culture (and previously to the PDH) for more than 13 years of their existence, they were managed more as a non-governmental organization than as a public service. They received no funds from government and their involvement in defending human rights went far beyond the normal role of a National Archive, their primary function being to hunt out cases that could be brought to trial and provide input for the public prosecutors and PDH investigators. But this state of affairs turned out to be untenable in the longer term, especially at a time when the country was faced with the difficulties caused by the changes underway under President Jimmy Morales that culminated, in 2019, with a change of political direction. The result was that the Ministry of Culture is now fully responsible for these archives, albeit following major culling, and for footing the corresponding bill, all international aid and the agreement with the UNDP having been summarily terminated. The documentary fonds of the Historical Archives of the Nation is now an integral part of the AGCA, this time not only in name. This development signalled the end of an experience unparalleled in other parts of the world, an example of archiving activism, the extent and limits of which deserve analysis. The case of Guatemala begs the question 
of whether it is really possible for the records of a state agency, such as the National Police, to be independently managed by groups of militant professionals supported by human rights defence organizations and through international cooperation. How long can such an arrangement last and what limits should there be to funding? Seen from the other end of the telescope, the real question is whether it should be incumbent on the State to take responsibility for preserving and providing access to such documents. Is the Guatemalan Government capable of assuming this responsibility? There is no easy answer to these questions, in particular in a country such as Guatemala, which has never had clearly defined, robust and consistent policies with regard to memory. In Part 2, Chapter 17, Kirsten Weld's offers plentiful information about this extraordinary tale. ${ }^{28}$

One thing that appears clear is that in a country like Guatemala, which has no specific institution similar to those in Germany, the Czech Republic, Argentina or other countries to manage the records inherited from the now defunct agencies of repression and make them available to the transitional justice authorities, and which has no clear policies with regard to tracking down the people responsible and making reparation for the atrocities perpetrated, the only valid option is to turn to the National Archives for their safekeeping, following the examples of Portugal, Brazil or Spain. This way these records will be preserved and kept in accordance with accepted professional standards and best practices. In 2009, it seemed that this was the option selected by Guatemala, but it then patently demonstrated its inability to follow through. In 2019, the AHPN was apparently forcibly transformed into an agency answerable to the government with all the attendant uncertainties that this entails. This being the case, can we really question the ability of the powers-that-be to appoint or dismiss the Head Curator or senior managers of this institution? Can we refute their capability in deciding on employee numbers and the conditions of their recruitment to the civil service dealing with these documents? All we can do is demand that the authorities act in the proper interests of the society they represent and that they should recruit staff according to professional criteria. Should they fail to do so, they should be held accountable (González Quintana, 2019b).

In some cases, one of the arguments for destroying records of a former repressive regime was to prevent their indiscriminate use by the police or the army in a democratic society, especially in countries where transition had been a peaceful or "pacted" process. The aim was to make sure that they could not be used, now or in the future, to abuse human rights. This is what happened in Greece, where the new government ordered records to be destroyed on completion of the expurgation process, on the grounds that it was time to shake off the past or because they contained misleading information that could be reused (González Quintana, 1997). But eliminating these archives once and for all further complicates the task of recording the history of the particular period, the only sources then being individual and, probably, subjective accounts. In the end, it is the victims and future 
generations that are the losers. The moral debate around the preservation of these holdings culminated in a recommendation from the experts in favour of keeping them to protect victims' rights to rehabilitation or reparations and enable the courts to rule on responsibilities.

These records are important because they bear witness to the past and to history and because they can enable victims to exercise their rights. The risk of a return to despotic practices can be obviated through international safeguards to protect the archives of repressive regimes by applying for their inclusion in the international Register of UNESCO's Memory of the World programme. Indeed, in its final report, the working group set up in 1995 by the International Council on Archives and UNESCO to examine these issues proposed that documentary fonds of this kind be included in this Register. As shown in the Introduction to this book, this is exactly what happened during the years 2003-2011.

During the transition processes, it was therefore considered vital by victims associations and human rights organizations to establish where records of this nature were located so that they could be handed over to the new democratic authorities and included in their archiving systems, together with suitable legal and physical safeguards and regulations governing their use. The idea was that this would make it easier for victims to obtain access to their personal files and for the courts, truth commissions and government agencies requiring proof to get hold of the records required to enforce the new democratic laws (on rehabilitation, amnesty, restitution, compensation, etc.). But all this is naturally contingent on major changes being made to the legislation in force.

\section{The archives of human rights NGOs}

One of the most striking phenomena of the 1980s was the arrival of civil society organizations on the international scene. In Latin America, these organizations campaigned against the self-amnesty laws that made it impossible to prosecute the perpetrators of violations and effectively introduced the principle of impunity. The Mothers and Grandmothers of the Plaza de Mayo in Argentina were among the first to push for information about the disappearance of their children and to campaign for the return of the so-called stolen babies to their real families. Their movement, which began in 1977, had a huge effect on Southern Cone and Central American countries. The Latin American Federation of Associations for the Relatives of the Detained and Disappeared (FEDEFAM), formed to raise the movement's profile, played a crucial role in bringing this tragedy to the world's attention (Joinet, 2002, p. 115). In the Mediterranean Basin, for example, 26 associations from 12 countries joined forces in a network around the EuroMediterranean Association against Enforced Disappearances (FEMED) with the goal of restoring truth and justice in the case of tens of thousands of enforced disappearances recorded in the countries concerned. 
In places where the archives of police and intelligence services have been deliberately destroyed, "cleansed" or hidden by officials determined to erase all traces of the crimes perpetrated or where the authorities refuse access to these records, the only alternative is to find other sources of information to establish proof of violations. And the archives of civil society organizations, of associations of the families and relatives of victims and survivors and of organizations for the defence of human rights offer valuable yet vulnerable alternatives.

Their records are also interesting on other grounds, for even when police files are not destroyed, they have to be used with care, because their impartiality is open to doubt and they may contain deliberately misleading information. It is therefore vital to be able to consult the archives of the NGOs in the hope of arriving at the truth. This is particularly the case in Latin America, for example in Argentina, Chile and Peru, where most of the records produced in the days of repression have gone missing, in contrast to those of countries in Central and Eastern Europe. Anne Pérotin speaks of a "lost continent of archives, the continent of military archives" (continent d'archives perdu, celui de la sécurité militaire) (Pérotin-Dumon, 2007, p. 86). While some documents may occasionally resurface and whole fonds of archives may, as we have already seen, suddenly reappear, such occurrences remain the exception.

Civil society organizations have the dual role of defending the victims and denouncing unlawful, political or military violence involving the State. Victim support associations tend to start out by covertly collecting information and personal testimonies for later use in proving the abuses endured by victims. The International Convention for the Protection of All Persons from Enforced Disappearances is a binding text that makes enforced disappearance a crime against humanity and therefore not subject to statutory limitations. ${ }^{29}$ The right of families to know the truth has no time limit and takes precedence over the right to justice, which expires on the victim's death. Families cannot achieve closure if they do not know where their loved ones are buried and are haunted by the need for proof that they are truly dead. To justify their actions when denouncing violations, the NGOs painstakingly pursue their investigations and analyses of the facts they have successfully collected. They produce files to help trace the bodies of missing persons, draw up lists of names and places, mass burial grounds, etc. and crossreference data with the information obtained from personal testimonies.

These NGOs produce various sorts of records depending on whether they are defending detainees or looking for missing persons:

1 Victim files containing all the documents collected to prove the existence of the missing person: birth certificate, family register, school reports, identity documents, health records, graduation certificates, private correspondence, mementos, photos and letters of the victim, personal testimonies, medical certificates and death certificate. 
2 Statements and claims filed by victims, documents lodged by lawyers, individual or collective demands for habeas corpus submitted by lawyers, and testimonies from survivors about the circumstances of repression. These first two categories may be used as evidence in court and the records concern named individuals. The data they contain are therefore sensitive.

3 Documents bearing witness to their communication efforts to prevent victims from being forgotten and put faces on victims: press releases and press kits relating to protest marches and campaigns staged to alert and stir up national and international public opinion, lists of victims and secret detention centres, posters, brochures, banners, pennants, placards, radio programmes and broadcasts, for example in Peru where the aim was to overcome the sense of isolation felt by Andean peasant farmers (Pérotin-Dumon, 2007, p. 70).

4 Documents targeting foreign nations and international intergovernmental and non-governmental organizations to build up awareness, create a wall of protection and report the facts, information transmitted to embassies, reports from religious organizations to the World Council of Churches, assignments carried out by Amnesty International and the Organization of American States (Pérotin-Dumon, 2007, pp. 65-66).

5 Sound or audiovisual recordings, oral testimonies collected from witnesses at the time or after the event.

All this material is unique and particularly at risk in the sense that the victim support associations often had to rush to collect information and personal testimonies in the utmost secrecy for later use as proof in cases of abuse. Long-term preservation was never one of the priorities of the activists and volunteers operating in repressive regimes, who had to keep changing addresses because of the threats hanging over their heads and the raids conducted on their homes. Documents could easily go missing or be lost, for want of resources or simply through carelessness, with these organizations being focused more on immediate and emergency action than on long-term preservation.

In addition, activists aware of the need to hold on to evidence tend to treat the papers in their possession as material for individual remembrance, with the risk that fonds, or collections of documents, may be split up. They often confuse documentation with archives and therefore treat archival records like documents in the sense that they are so obsessed with the content and its importance that they tend to forget the context in which the material was produced, which then makes it more difficult to interpret. If the organization is disbanded, there is the very real likelihood that records will be taken home by the people in charge, for whom they are almost like family documents, long stashed away, which further exacerbates the risks. Not only are they often fragile and in poor condition, but they also take a variety of forms. And it is not only posters, tracts, publications, photos, 
audio and visual materials and other objects that are vulnerable. There is the added complication of born digital records, databases and websites, which need regular updating. Failure to do so could prove fatal now as computers are in such general use.

These records represent a threat to the authorities in repressive regimes and it is not unusual for them to be confiscated or destroyed. The computer files of the Russian association Memorial, which offers legal and financial aid to Gulag victims and carries out research into past political repression, were seized by the police in 2008, which walked off with hard disks containing huge volumes of data about crimes perpetrated under Stalin. In Chile, the archives of the Vicaria de la Solidaridad (Vicariate of Solidarity) came under systematic attack and the Head of its Analysis Department, José Manuel Parada, was even assassinated in 1985 (Pérotin-Dumon, 2007, p. 77).

Chile is not the subject of a case study in this book, but it is interesting all the same in that, in contrast to Argentina, the Catholic Church was firmly behind the NGOs, the Vicariate being the most important example of its involvement. This diocesan agency was manned by some 100 employees, lawyers, social workers and researchers and a network of several thousand people and, while the dictatorship was in power, provided legal and administrative assistance to 49,000 victims and their relatives. Its lawyers conducted investigations that the police and the courts refused to undertake and took legal action on behalf of victims' families. The Vicariate acted as a news agency circulating information outside Chile and published a biweekly magazine distributed nationwide. Its archives are the largest human rights holdings of the whole Latin American continent with a total of 700 linear metres of records (Pérotin-Dumon, 2007, p. 54).

The Church was also engaged in victim defence in Brazil and Guatemala. "Brazil, Never again" (Brasil Nunca Mais), ${ }^{30}$ a project supported by the World Council of Churches, managed to collect thousands of depositions and documents on the country's military dictatorship (1964-1985) that made it possible to identify the torturers. Copies of these archives are held at the Center for Research Libraries in Chicago and at the World Council of Churches in Geneva (Groppo, 2012). In Guatemala, the Human Rights Office of the Archdiocese of Guatemala (Oficina de Derechos Humanos del Arzobispado de Guatemala) has placed all the documents it issued and collected, including those produced during the "Recovery of Historical Memory" project (Recuperación de la Memoria Histórica - REMHI) in the safekeeping of the Memory Centre of Monsignor Juan Gerardi (Centro de Memoria Monseñor Juan Gerardi).

In countries that have re-established democratic regimes, it is difficult for the State to take action to protect NGO archives, as these are private holdings. Records often concern named individuals and are therefore classed as sensitive, and NGOs are hesitant to transfer them to public archives, which they regard with mistrust. However, in recent years, a number of heritage 
associations have appeared on the scene and major progress has been made in the way archives are handled: in Argentina, the Memoria Abierta association, which is an alliance of nine victim and human rights defence associations, and in Chile, the Vicariate Foundation, have both started applying professional principles to their working methods and have become benchmarks for their peers.

NGOs have made key contributions to efforts to exercise the right to justice by supplying the truth commissions and courts with the reliable and compelling data they were able to obtain through their outreach and direct contacts with witnesses. Their archives are extremely valuable in helping to establish the facts, because the information was often recorded in the immediate aftermath of events. The records of the Vicariate in Chile were, for example, used by the Valech Commission on Political Imprisonment and Torture, which was given access to some 20,000 files (PérotinDumon, p. 84).

\section{Archives of International Tribunals and Truth Commissions}

While international tribunals and truth commissions are constantly chasing the records they need for their work, they in turn produce records of vital importance in understanding past events, many of which are oral depositions obtained during trials, in the case of the courts, or hearings, in the case of the truth commissions. These tribunals and commissions have one thing in common, namely that as temporary structures for delivering transitional justice, they are systematically faced with the problem of what to do with their own records, when they come to the end of their remit.

We have already spoken of the importance attached in 2015 by Pablo de Greiff to the information that truth commission archives can provide for other purposes than their own. Pablo de Greiff insists on the need for these records to be made accessible, provided that this does not infringe nondisclosure agreements reached with victims or perpetrators of violations only prepared to make statements under this condition. But, for his recommendations on the use of these archives to be possible, it is first necessary to find a solution to the problem of ensuring the preservation and management of this documentary heritage. Where truth commissions are concerned, the situation differs radically from one case to another.

Commissions enjoying the support of the United Nations, such as the Guatemala Historical Clarification Commission (Comisión para el Esclarecimiento Histórico de Guatemala), transferred their archives to the UN Headquarters in New York on completion of their work and publication of their final report. The records were then to remain classified for 50 years. This inaccessibility was not the only problem. There was also the downside that all this material providing irreplaceable information about a nation's past was taken out of the country. A similar situation occurred with the archives of the El Salvador Truth Commission. 
In cases where commissions owe their creation to the national authorities, the solutions proposed for their records also varied widely.

A first option was to transfer these records to the National Archives. This is what was decided in South Africa by the Truth and Reconciliation Commission headed by Archbishop Desmond Tutu, in line with the recommendations of its final report. In Part 2, Chapter 2, Graham Dominy offers us a detailed overview of events in South Africa. The same approach was adopted for the archives of Brazil's National Truth Commission (Comissão Nacional da Verdade). Once the Commission had completed its work, its documentary fonds were transferred to the National Archives. In this publication, Aluf Elias offers, in Part 2, Chapter 15 , a case study with regard to these archives. In Tunisia, the Truth and Dignity Commission also handed its archives over to the National Archives on completion of its mandate, though not without controversy, as outlined by Adel Maïzi in Part 2, Chapter 3.

Another option consisted of transferring commission records to one of the new archival institutions set up to help come to terms with the country's troubled past and enable this material to be used by the courts or victim reparation schemes. This is what happened with the archives of the National Commission on the Disappearance of Persons (CONADEP) created in Argentina in 1983 under President Raul Alfonsín in the postmilitary dictatorship period, which were later transferred to the National Archive of Remembrance set up in 2002. These records were vitally important in the legal action taken following the abrogation of the so-called Due obedience and Full stop laws passed during Nestor Kirchner's tenure as President.

In Chile, the archives produced by the different truth commissions are held in safekeeping by the Museum of Memory. These range from those of the original Truth and Reconciliation Commission, chaired by Raul Rettig and set up under President Patricio Aylwin, to those of the National Commission on Political Imprisonment and Torture chaired by Monsignor Sergio Valech via the National Reparation and Reconciliation Corporation under its President, Alejandro González Poblete. The Museum was created under the presidency of Michelle Bachelet to look into the country's violent past. The fonds is, however, only accessible to governmental human rights organizations.

On completion of its mandate and delivery of its final report, Peru's Truth and Reconciliation Commission decided to transfer its archives to the Public Defender (Defensoría del Pueblo), an institution set up in 2004 by the Information Centre for Collective Memory and Human Rights (Centro de Información para la Memoria Colectiva y los Derechos Humanos), where they are still held today. It was this centre that was tasked with circulating the archives of Peru's Truth Commission to public organizations, the families of victims of internal armed conflict, universities and those keen to discover the truth about events in Peru during the period 1980-2000. Part 2, 
Chapter 14 by Ruth Elena Borja Santa Cruz focuses on the subject of the archives of the Peruvian Commission.

One particularly striking example is that of Liberia's Truth and Reconciliation Commission. Once it had completed its work, the government in office was not in a position to take charge of the Commission's archives and decided, as a result, to send them for safekeeping to the Georgia Institute of Technology in the United States (Svärz, 2009).

The problems arising in connection with production of this type of documentary fonds and the alternatives for their management have been analysed in depth by Trudy H. Peterson (2005).

Temporary tribunals set up in post-conflict situations, at times as a result of resolutions voted by and directly linked to the United Nations, produce sets of documents that are extraordinarily valuable for remembrance in the countries concerned, in both case law and content terms (Kaye, 2014). The Special Tribunals for the former Yugoslavia and Rwanda created as a result of resolutions voted by the UN Security Council, the Tribunal for Sierra Leone that owed its creation to an international treaty, the Tribunals for East Timor and for Kosovo set up by UN Missions are also cases in point. The temporary nature of these institutions is an invitation in itself to think ahead to more permanent solutions, because the material they produce constitutes archival fonds with obvious informational value, which should be ample justification for their permanent preservation.

Not only did these temporary tribunals collect vast quantities of key documents in their search for written proof for use by the prosecutors but, during their sittings, they also churned out large numbers of records containing invaluable details of the events that occurred. Two iconic examples of this are the series of video recordings kept in the Archives of the Special Tribunal for Rwanda (Hunt, 2011) and the Gacaca Archive, which is the subject of Part 2, Chapter 5 by Peter Horsman.

The real issue here is where and under what authority archives should be kept once the tribunals have been disbanded. One possibility would be to entrust them to the care of a new agency to be set up at the headquarters of the International Criminal Court in The Hague, which could be tasked with the long-term preservation of all the archives produced by temporary special tribunals. Another alternative would be for those produced under the auspices of the United Nations to be transferred to the archives of the UN Office at Geneva. A third possibility could be to entrust them to the corresponding National Archives. This last option would probably be the most suitable, once the records have been used for all the legal and administrative purposes for which they were initially intended, because they would thus remain an essential part of the memory structures of the countries concerned. This would depend to a large extent on these countries actually owning the material produced and, more particularly, on the capacities and guarantees offered by the transition processes that follow 


\section{Gross human rights violations}

the special tribunals (Peterson, 2006). This solution would, however, not work in the former Yugoslavia, because the archival institution created there holds records relating to the different countries that have emerged from the disintegration of the old federation. At all events, the fate of these archives continues to remain an issue yet to be definitively resolved. 


\section{Archives and transitional justice}

In countries where military dictatorships, racist and segregationist governments or communist regimes have been overthrown and replaced by democratic governments, archives have rapidly emerged as an essential feature of what is called "Transitional Justice" as they progress towards democracy. According to the definition of the United Nations: The notion of transitional justice comprises the full range of processes and mechanisms associated with a society's attempts to come to terms with a legacy of large-scale past abuses, in order to ensure accountability, serve justice and achieve reconciliation. For the International Centre for Transitional Justice (ICTJ), it may be defined as follows:

[T]ransitional justice is a response to systematic or widespread violations of human rights. It seeks recognition for victims and promotion of possibilities for peace, reconciliation and democracy. Transitional justice is not a special form of justice but justice adapted to societies transforming themselves after a period of pervasive human rights abuse. In some cases, these transformations happen suddenly; in others, they may take place over many decades.

The cornerstones of transitional justice and the battle against impunity are four of the tenets set out in the international standards on human rights: (a) the State obligation to investigate and prosecute alleged perpetrators of gross violations of human rights and serious violations of international humanitarian law, including sexual violence, and to punish those found guilty; (b) the right to know the truth about past abuses and the fate of disappeared persons; (c) the right to reparations for victims of gross violations of human rights and serious violations of international humanitarian law; and (d) the State obligation to prevent, through different measures, the reoccurrence of such atrocities in the future (OHCHR, 2014). Four basic mechanisms are proposed to help attain these goals: reparations for victims, trial of criminals, institutional reform and expurgation of officials who took part in the crimes perpetrated under the old regime and creation of truth commissions. New archival institutions, such as the Federal Commissioner 
for Stasi Records set up in 1990 in newly reunified Germany, have laid the foundations for a new era in the use of archives and records in defence of human rights.

While the relationship between archives and human rights exists at all levels, publications on the subject tend to focus exclusively on human rights violations and the defence of human rights in countries where abuses have occurred. This blinkered approach often means that, when speaking about archives and human rights in countries transitioning to democracy, the need for medium and long-term objectives with regard to archival policy tends to be overlooked. It is too easy to forget that public sector agencies require robust records management policies and an archival system synonymous with open, transparent societies respectful of human rights. A strong national archival system is essential to ensure that records important for the promotion and protection of human rights are preserved (OHCHR, 2015, p. 9).

But until a new system can be put in place, fledgling democracies need to face up to their pasts and, for this, they need records. Extraordinary provisional archival policy measures therefore need to be established so that archives can cease to be treated simply as cultural institutions but as key players in transitional justice. Archives are essential in supporting the mechanisms of which their institutions could form an integral part. This is potentially true of the many new-style archival institutions that have emerged in countries engaged in a process of political transition, from the Federal Commissioner for Stasi Records to the many different memory centres or archives.

Even in cases where the approach adopted to political transition was more one of studied amnesia than anything else, the quintessential example of which is post-Franco Spain, a number of more or less extensive practical transitional justice measures were introduced to come to terms with the past. These included the trial of those responsible for atrocities, the establishment of truth commissions and mechanisms conducive to reform and democracy or measures to rehabilitate victims and make amends for the damage they had suffered.

In the end, the approach adopted to transition is largely coloured by factors such as the existence of archives and records to show the full horror of the human rights violations perpetrated and the policies adopted to manage these records. By contrast, when politicians make the deliberate decision to forget or draw a veil over the past, the fate of records and archives is sealed with dramatic consequences. If there are no supporting documents, transitional justice will be hobbled, leaving it with few alternatives, which is why documents recording human rights violations must be kept, transparently managed and made accessible to citizens.

\section{Archives and the right to truth}

The right to truth, as we have seen from the preceding theoretical analysis, will only be possible if nations have the ability to know the truth about 
traumatic past events. For transitional justice in its various forms, the key instrument has to be truth commissions, which are usually official public institutions set up at the highest political level to put the past to rest. Members tend to be legal experts, well-known intellectuals and prominent personalities, all broadly representative and reputed in their fields. Most truth commissions also have the word "reconciliation" tagged on to their title to emphasise the fact that their role is also that of rising above the past and preventing denial and recurrence. A large number of truth commissions have been set up in more than 35 countries where repressive regimes have finally been ousted, on the basis of this approach of seeking to reach consensus on a shared version of the traumatic events of the past. ${ }^{31}$

It is important to remember that the right to the truth is a collective right that has no limits in time and space. No limits in time, in the sense that records will be used long after they have fulfilled the functions for which they were originally intended, and no limits in space because they can be, and have already been, used outside the national boundaries of their "home" countries.

The Red Cross International Tracing Service Archive, in Bad Arolsen is perhaps the perfect example of this cross-border dimension, because it can provide information about Holocaust victims to a substantial number of people in many different countries anxious to learn their loved ones' fate. Information comes from records produced by the authorities in charge of the Nazi concentration and death camps and is managed by the International Tracing Service (ITS), which since May 2019 is named Arolsen Archives, International Centre on Nazi Persecution (Borggräfe, Höschler, and Panek, 2019). Eloquent illustrations of the international role of this agency are the sentences pronounced against war criminals or court rulings in cases brought against individuals accused of crimes against humanity (Arendt, 1963; González Quintana, 2011).

State security records in countries that have gone from totalitarian to fully democratic regimes, such as those of the Stasi in Germany or the secret police in other countries (Schiller-Dickhut and Rosenthal, 2014), are probably the best example of records that are both timeless and intergenerational. These records, which were originally used by dictatorships as weapons of persecution and repression, now constitute vital evidence for rehabilitating victims of human rights abuse and for ensuring redress, not only during the political transition phase but also when judging wrongdoers and for bringing the truth about events in the immediate past to light. To paraphrase the eminent Dutch archivist, Eric Ketelaar (1992), they have become archives "for the people" instead of "against the people".

In this process of trying to uncover the truth about past events, Spain is the prime example of the intergenerational importance of archives. The protagonists of the major changes that took place in Spain between 1977 and the end of the 20th century took the decision not to enforce policies for managing the past, on the pretext that, without them, democracy would be more easily achieved. Recourse to archives was only made in a few modest 
cases of reparation. But 30 years after the start of the transition process in Spain, the younger generations began to demand explanations for studiously occulted episodes of the past, for example about the whereabouts of missing persons. More generally, they wanted to know the truth about the atrocities perpetrated during and after the Civil War. And to provide them with the explanations they were demanding, archives and records were an essential part of the process. In the early stages of political transition in Spain, from 1975 to 2004, ignorance was the order of the day. This is borne out by the decision to rename documentary fonds of an obviously repressive nature, such as those produced by Franco's intelligence services in Salamanca between 1937 and 1977. These were to become the "Civil War" Section at the National Historic Archives (Archivo Histórico Nacional) before being renamed the "General Archive of the Spanish Civil War" and, since 2005, ${ }^{32}$ the Historical Memory Documentary Centre (Centro Documental de la Memoria Histórica) as though they were simply an academic research centre within an archiving system, on a par with the General Archive of Simancas (Archivo General de Simancas) or the General Archive of the Indies (Archivo General de Indias). Instead of simply offering researchers a set of documents for piecing together the history of the Civil War, it would in reality have been better, under transitional Spain's new legal framework, to face up to the task of managing a vast series of records produced by the system used by the police to control the population and containing 40 years of information about individual Spaniards. From the very first laws on reparation for Civil War victims, it was immediately obvious that this was what should have been done.

But the backdrop to transition was to change dramatically two decades later. Spain was inevitably caught up in the general movement of the $1990 \mathrm{~s}$ and the insistence that the truth about crimes against humanity and genocides and other similar atrocities be revealed. This wave of opposition to the principle of impunity put demand for memory, truth and justice on a common course. After the experience of the truth commissions, the establishment of the International Criminal Court in 1998, the actions of Judge Baltasar Garzón in recognising the universal jurisdiction of this Court in prosecuting Augusto Pinochet or against the perpetrators of repression in Argentina and the appearance of pro-memory movements in Latin America and Europe, associations for the recovery of historical memory began to spring up throughout Spain. In Part 2, Chapter 8, Henar Alonso Rodríguez offers further analysis of the particular case of Spain.

\section{Archives and the right to justice}

As rightly pointed out by Trudy Huskamp Peterson (2011, 2014; see also her Chapter 1, Part 2 in this book), while records may be universally used in trials, not all documentary evidence is equally reliable. She reminds us that, in 2006, the High Commissioner for Human Rights published research into 
the rules to apply in trials, highlighting the "vital" importance of documentary evidence: Documentary evidence may have advantages over personal testimony, as it may help to prove matters more quickly and succinctly. It is not subject to the difficulties presented by intimidation and changing disposition of witnesses. Although always subject to interpretation, it can often provide more conclusive evidence of specific events or orders than personal recollections or conjectures (OHCHR, 2015, p. 13).

The Nuremberg trials amply demonstrated the importance of archival documents and their significance in criminal trials. But the evidence used to judge war crimes or crimes against humanity in the aftermath of World War II points clearly to the determination of the Allies to convict senior Nazi officials. The lengthy Nuremberg trial clearly flagged up the importance of collecting evidence and of using expert skills to process the piles of records produced by the National-Socialist state machinery and, more particularly, its repressive agents or those of the party in power. The best confirmation of this is to be found in the outline provided by Robert G. Storey, Executive Trial Counsel for the United States at the Nuremberg Trial, of "the method of capture, processing and assembling documentary evidence used at the Trial, and the plan of presentation to the Tribunal" (Trial, 1947).

In his deposition before the tribunal, Storey explains that

as the United States Army advanced into German territory, there were attached to each Army and subordinate organisation specialised military personnel whose duties were to capture and preserve enemy information in the form of documents, records, reports and other files. The Germans kept accurate and voluminous records. They were found in Army headquarters, government buildings and elsewhere. During the later stages of the war particularly, such documents were found in salt mines, buried in the ground, behind false walls and many other places believed secure by the Germans. For example, the personal correspondence and diaries of Defendant Rosenberg, including his Nazi Party correspondence, were found behind a false wall in an old castle in Eastern Bavaria. The records of the Headquarters of the Air Staff (Luftwaffe) were found in various places in the Bavarian Alps. Most of such Air Force records were assembled and processed by the Army at Berchtesgaden. When the Army first captured documents and records, they immediately placed the materials under guard and later assembled them in temporary Document Centres. Literally hundreds of tons of enemy documents and records were screened and examined and those selected were forwarded to Nurnberg for processing.

These documents were essential in establishing the guilt of the accused.

But the Cold War was to thwart the movement set in motion in Nuremberg, not only in that politicians were no longer determined to haul the criminals before the courts, but also, paradoxically, in that they welcomed 
former criminals with open arms into their Security services to help them in the battle against their new enemies. The classic case in point is that of Klaus Barbie, who was accused of crimes against humanity for his role as the head of the Gestapo in Lyon. Demands by the French Government were consistently ignored by the U.S. authorities for whom Barbie was a kingpin in their anti-communist efforts. He was even recruited by the U.S. intelligence services, first in Europe and later in Latin America, to collaborate with the agencies combatting "subversive movements". In Bolivia, he was the main adviser to Banzer's and García Meza's totalitarian regimes in their efforts to quell their political opponents. The following documentary evidence is a damning proof that the accused, Luis García Meza and Luis Arce Gómez, were the organisers of armed paramilitary groups patently under their immediate authority and control. Perhaps the strangest and most incredible evidence is the undertaking signed on 12 February 1980 by Klaus Altmann Hansen - alias Barbie - and the accused Luis Arce Gómez, who, at the time, was in charge of Department 2 of the Army, which reads as follows:

I I, Klaus Altmann Hausen, ${ }^{33}$ undertake unconditionally to provide services to the Bolivian Army in respect of intelligence.

II I also undertake to play a direct part in planning and operations as required by the Bolivian Army, in which my active involvement is required.

III I promise, on my own head, to maintain secrecy with regard to everything that may occur or exist, everything that I know of or in which I may take part.

IV I, Colonel, DAEM, Luis Arce Gómez, in the name of the Army of the Nation and the obligations incumbent upon me, and with the approval of my hierarchy, hereby bestow the rank of Honorary Lieutenant on Mr Klaus Altmann Hausen.

The aforementioned document, signed by the accused, Luis Arce Gómez, on 12 February 1980 and by a foreign national convicted of "war crimes" by the French courts, is evidence of the preparations made to organise irregular groups with the consent of Luis García Meza. It is therefore amply demonstrated that the above-mentioned individuals set about the premeditated organisation of irregular groups, these groups then acting under their direct orders; /. . . /

(Supreme Court of Justice of the Nation. Court ruling in the lawsuits brought by the Attorney General's Office and other plaintiffs against Luis García Meza and his associates. 21 April 1993. Sucre, Bolivia)

It would be wrong to say that no war criminals or perpetrators of genocides, Nazi criminals in particular, were brought to trial during the Cold War period, but prosecutions were internal to the countries where the crimes had taken place: Poland, Soviet Union, Hungary, etc. (with the notable exception of Israel). More remarkably, trials were also staged in 
Germany following the creation of the Central Office of the State Justice Administrations for the Investigation of National Socialist Crimes in Ludwigsburg in 1958 (Schrimm and Riedel 2008, pp. 525-555). The trial of Adolf Eichmann in Jerusalem in 1961 made headline news worldwide, not least because of Hannah Arendt's controversial trial report (1963). Eichmann, one of the major protagonists with regard to the "Jewish question" under the Nazi administration and one of the main organisers of the "Final Solution" that culminated in the Holocaust, was brought to trial by the State of Israel, following his abduction by the Israeli Secret Service.

In France, the 1980s saw the start of a series of trials against "forgotten" prominent officials in France's collaborationist Vichy government, not least René Bousquet and Paul Touvier, as well as Maurice Papon, whose trial was to be the high point (Kitson, 2000). The large-scale trial of the military juntas in Argentina, in which the dictators were given heavy sentences for their crimes, also took place during this period, although the "Full stop" and "Due obedience" laws that immediately followed effectively rendered these sentences null and void. Last but not least, after his extradition to France, in 1983, Klaus Barbie was, in 1987, tried and sentenced to life imprisonment in highly mediatised court proceedings (Mateva, 2006).

However, as Manuel Ollé points out, it was the Ad Hoc Criminal Tribunals for the former Yugoslavia (1993) and Rwanda (1994) that truly signalled the revival of the Nuremberg spirit. The difficulty is that these supranational courts were deliberately vested with limited powers which made it impossible for them to try all the cases of crimes against humanity or genocide brought to their attention. Separate tribunals were therefore set up in each national case (Sierra Leone, Lebanon, etc.). But it was only when the International Criminal Court (ICC) came into being in 2002, following the adoption of the Rome Statute of the ICC in 1998, that there finally existed a tribunal qualified to judge crimes of this nature over and beyond national boundaries. Even then, the Court was to limit the scope of its jurisdiction to crimes committed after 2002 (Ollé Sesé, 2009).

The widespread application of the principle of universal jurisdiction was the apotheosis of moves in support of demand for remembrance, truth and justice. "Universal jurisdiction" allows jurisdictional bodies to prosecute and pass judgement on crimes of this nature when the countries where they occurred fail to take the necessary action. The cases that acted as pathfinders in this respect were the retrial in Spain of ex-members of the Argentinian military juntas in power between 1976 and 1983, who had benefitted from the amnesty laws and, more particularly, the trial of Augusto Pinochet, which stands out for its impact and significance. While the trials of Eichmann and Barbie may have set precedents, they were no more than delayed reflections of "international post-war justice" designed to punish Nazi criminals and their accomplices in the Holocaust.

The case of Augusto Pinochet is also interesting in that it was the first time that, in the name of the universal jurisdiction enshrined in the conventions 
giving the Nuremberg Principles their place in law, a magistrate from a third country, Baltasar Garzón, was able to bring to trial in Spain, a man who was not a Nazi war criminal but a Latin-American dictator accused of gross human rights violations, completely distinct from the Jewish genocide. This trial paved the way for similar action on the part of growing numbers of other countries in Europe and the Americas. In Italy, the investigations conducted by prosecutor Giancarlo Capaldo culminated in the indictment, at times in absentia, of a number of Latin American dictators on the charge of having caused Italian nationals to disappear (Barrera, 2011). A landmark example was that of the trials of Chadian dictator Hissène Habré, the final upshot of which was his conviction by the Extraordinary African Chambers. The trials were facilitated by the discovery and use of the records of his secret police, which played a decisive role in securing his conviction. The trials and the use made of these documents are analysed in Part 2, Chapter 4 by Henri Thulliez. In Guatemala, many of those responsible for gross human rights violations during the Civil War were brought before the courts as a result of documents supplied by the Historic Archive of the National Police (Archivo Histórico de la Policía Nacional).

\section{Archives and the right to reparation}

Ensuring long-term preservation of records produced in connection with political repression is essential because such records can provide unique evidence of the sufferings of people. In new democracies, the strongest argument for preserving records that provide proof of human rights violations are, firstly, their importance for the victims of repression and, secondly, their major role in the new political climate in enabling citizens to claim their individual rights: rehabilitation, amnesty, reparation, compensation, pensions and return of confiscated assets. Records are vital to show what happened to the victims and how they were abused, so they or their relatives can qualify for reparation, justice and knowledge of the truth. Trudy Huskamp Peterson deals with these questions in her essay "Proof", reproduced in this book (Part 2, Chapter 1). Archives, which were essential for stamping out political, religious, ethnic or ideological dissension and which were a fundamental part of the former repressive regimes, can be converted under the rule of law into irreplaceable weapons for enabling victims to exercise their rights to redress for the harm suffered and for imposing sanctions on those responsible for the atrocities perpetrated. This has been referred to as the "boomerang effect" of archives and records created for use in political repression and to exert control over the lives of the population (González Quintana, 1997).

The right of the victims of human rights violations to reparation, whether material or symbolic, has been recognised by the United Nations in a large number of documents and by several of its special rapporteurs. While there exists the precedent of the compensation paid by Germany to Nazi victims, ${ }^{34}$ 
it was the principles established by the United Nations with regard to reparation (UN, 2006) that were taken as a basis in many countries for their reparation schemes for the victims of political repression or human rights violations. The UN studies in this field started in 1988 (Cruz, 2010) and the first report from the UN special rapporteurs on impunity and reparation dates from 1993. It was the work of Theo van Boven, revised and expanded a few years later by Cherif Bassiouni, which laid down the basic principles and fundamental guidelines to be used as a basis for victim reparation policies:

Under international law, the violation of any human right gives rise to a right of reparation for the victim. Particular attention must be paid to gross violations of human rights and fundamental freedoms, which include at least the following: genocide; slavery and slavery-like practices; summary or arbitrary executions; torture and cruel, inhuman or degrading treatment or punishment; enforced disappearance; arbitrary and prolonged detention; deportation or forcible transfer of population; and systematic discrimination, in particular based on race or gender.

And for victims to be able to exercise their rights, there is a condition directly involving archives:

1. . .117. Every State shall make readily available all evidence in its possession concerning human rights violations. 18. Administrative or judicial tribunals responsible for affording reparations should take into account that records or other tangible evidence may be limited or unavailable. In the absence of other evidence, reparations should be based on the testimony of victims, family members, medical and mental health professionals.

In his report, Bassiouni (2000) confirmed the right of victims to stake their claim to justice, reparations for the harm suffered and access to information about violations. On the issue of reparation, they should be entitled to adequate, effective and prompt remedy. Reparation may take the form of restitution, compensation, rehabilitation or satisfaction, and it guarantees on non-repetition. The report also includes a section on the right of victims to accede to information. For archivists, this is of particular interest. In Part XI of the report on "Public access to information", Cherif Bassiouni stipulates that

States should develop means of informing the general public and in particular victims of violations of international human rights and humanitarian law of the rights and remedies contained within these principles and guidelines and of all available legal, medical, psychological, social, administrative and all other services to which victims may have a right of access. 
A third report, submitted by the rapporteur, Alejandro Salinas, in 2004, was instrumental for the approval of the Basic Principles on the Right to Remedy and Reparation for Victims of Gross Violations by the UN General Assembly in 2005. The following paragraph is a quotation from this report, selected because it deals with access to relevant information about violations and repair mechanisms and introduces a number of major nuances to the version of the text of the Bassiouni report mentioned previously:

States should develop means of informing the general public and, in particular, victims of gross violations of international human rights law and serious violations of international humanitarian law of the rights and remedies addressed by these Basic Principles and Guidelines and of all available legal, medical, psychological, social, administrative and all other services to which victims may have a right of access. Moreover, victims and their representatives should be entitled to seek and obtain information on the causes leading to their victimisation and on the causes and conditions pertaining to the gross violations of international human rights law and serious violations of international humanitarian law and to learn the truth in regard to these violations.

Mention should also be made of the work of another rapporteur, Sergio Pinheiro, even though it only concerns one very circumscribed aspect of reparation policies, namely the right to housing and property restitution in the event of the return of refugees and internally displaced persons (war, disaster or political repression). In his report on the Principles with regard to the restitution process, he includes highly interesting references to the role of records and documentation. ${ }^{35}$ Archiving practices vary widely with regard to the documents made available to victims to enable them to enjoy the benefits of reparation and compensation schemes. One of the positive ways in which archives and records may be used to obtain reparation may be illustrated by the example of Spain: even though there were no specific reparation arrangements in place during political transition, a large number of laws were however produced covering not only pensions and compensation but also recognition for the victims of political violence under Franco and during the Civil War.

With the demise of the Franco regime and from the start of political transition until the introduction of the first laws on reparations following the approval of the Amnesty Law (Turrión, 2013), Spain ordered the "Civil War" Section of the National Historic Archives to make the necessary documents available to those entitled to benefit from the initial legislation. This is extremely significant, because, as we have seen, the first stage in the transitional process was otherwise devoid of conventional transitional justice measures (knowledge of truth, allocation of responsibilities, etc.). From 1990, the role of archives as part of reparation policies was extended to other national archives, to military archives and to further public archives 
such as those of the Court of Auditors, more particularly following approval of the proposal to compensate victims of repression for the duration of their imprisonment on political or ideological grounds. Archival institutions had to deal with huge number of enquiries during this period; over 100,000 people were seeking documents and information to support their reparation claims (González Quintana, 2007).

The systems put in place in Colombia, in application of the 2011 Victims Law, or in Guatemala, in the wake of the 1996 Peace Agreements, produced very mixed results, partly because of difficulties in producing reliable evidence, in particular archives and records. This does not mean that they were not ambitious. In Colombia, the problem may be ascribed to the highly complex institutions put in place, as Ramón Alberch i Fugueras tells us in Part 2, Chapter 13. In Argentina, the records of the National Commission on the Disappeared were at the heart of the reparation programmes for, without them, it would have been virtually impossible to establish the fate of victims. In Chile, for enforcement of Law 19.123 of April 1993 on the first redress owed to victims of dictatorship, it was access to the lists of victims contained in the final report from the National Commission for Truth and Reconciliation (CVR) which was the vital first step towards identifying further victims of gross human rights violations, in addition to those on the Commission's initial list (Hayner, 2011). In the process, collecting documentary evidence and personal testimonies was of crucial importance and involved using the documents inherited from the CVR and the reports obtained from the Vicariate of Solidarity (Vicaría de la Solidaridad) as a basis for extending research to a large number of government agency offices.

Several other countries have enforced reparations laws or programmes, among them being Brazil, Morocco, Peru, Portugal, Czech Republic, Sierra Leone and South Africa. In Part 2, Chapter 1, Trudy Huskamp Peterson offers an in-depth essay on the subject of reparations and compensation payments.

\section{Archives and "lustration": experiences in post-communist European countries}

Reform and modernisation processes in States with violent or totalitarian pasts are also part of transitional justice. For many of these processes, for example instituting democratic practices within the armed forces, professionalising the civil service or improving social or cultural services, archives can be of enormous help. But it is doubtless over the management of military and State security personnel that archives have exerted the strongest influence. Purging the ranks or disqualifying officials from public office is not normally a major issue, provided their names are obtainable from official publications announcing their appointment. But intelligence service officers and, even more particularly, the collaborators, beneficiaries or informants of these services are a different story, not least because their names were 


\section{2}

Archives and transitional justice

never public knowledge or were scrupulously kept under wraps. One way of unmasking such people is by sifting through the many security service records where their names appear, more or less in full, especially in former communist countries in Central and Eastern Europe.

These revisionist policies versus the potential benefits of leaving political and administrative managers or civil servants with similar positions under the previous regime in their jobs were labelled "personnel systems" by Roman David in 2011. In truth, the way of dealing with such individuals does not always involve screening and dismissal but can come in different forms, which David classifies into the three categories of "exclusive", "inclusive" or "reconciliatory". But these concepts and this manner of classifying personnel policies in transitional states have since been eclipsed by the notion of "lustration", a term invented in former communist countries in Central and Eastern Europe, whose policies were closely bound up with the process of dismantling their communist legacies after the fall of the Berlin Wall and the disbandment of the Soviet Union. According to historian Tony Judt (2005), "in none of these countries was the problem of coming to terms with the Communist past resolved to everyone's satisfaction".

In 1995, Herman Schwartz defined lustration as "an administrative mechanism for disqualifying and, where in office, removal of certain categories of officeholders under the prior regime from certain public or private offices under the new regime". As a general rule, this consisted mainly of exclusion from standing for political office but also sometimes extended to a ban on exercising certain professions, e.g. teaching. This definition does not, however, apply in all cases because the scope and punitive powers of the different lustration laws vary widely.

The first countries to use the State security archives of former communist regimes to enforce these personnel policies were Germany and the Czech Republic. In Germany, the process began even before specific legislation on "lustration" came into force, following the creation of the Federal Commissioner for Stasi Records through a law passed in October 1991 that defines the nature, role and responsibilities of this office. It was in the Czech Republic, the second of these countries, that the term "lustration" originally emerged, the Czech word being lustrace, which may be translated as "bringing to light". The term is originally derived from Latin and, in some languages has other connotations such as purification through sacrifice or cleansing through washing in holy water. In English, the term commonly used for this process is vetting, in other words, performing background checks. In a European context, use of the term "lustration" is closely linked with the use of State security archives for identifying those employed by these services, the conditions under which they worked and their individual roles, this information then being employed to enforce any necessary personnel policy measures.

In the Czech Republic, the Lustration Act was finally approved on 4 October 1991, but with far more stringent provisions. Its full title is Law 
on the Prerequisites for Nomination to Position in State Bodies and Security Corps, generally known in everyday parlance by the much simpler name of "Great Lustration Act", not least to distinguish it from the "Small Lustration Act", and to reflect the extent of its scope, given the large number of individuals ultimately concerned. Many former Czechoslovak Communist Party apparatchiks were removed from their posts, as were former military personnel (Blazek, 2006). The Czech Lustration Act was followed by similar legislation in Slovakia (1991), Albania (1992), Bulgaria (1992, 1997, 1998), Poland (1992, 1997, 1998), Hungary (1994, 1996) and Romania ${ }^{36}$ (1999).

Lustration is perhaps the most controversial aspect of transitional justice policies. The legitimacy and, on occasion, the constitutionality of the standards applied is frequently challenged, because of the lack of legal guarantees and the fact that the information contained in the secret police files was simply taken on face value, even though it could have been erroneous, bogus or incomplete. The lustration process also tends to become highly politicised and archives have been caught in the flak. In addition, some of these archives have been transferred to new bodies, such as Memory Institutions, themselves leading players in enforcing lustration policies, which has created an atmosphere of mistrust and suspicion in relation to these institutions (Olson, 2002). This compendium includes contributions from José M. Faraldo (Part 2, Chapter 9), Dagmar Hovestädt (Part 2, Chapter 10) and Marius Stan and Vladimir Tismaneanu (Part 2, Chapter 12), all of which provide details about the way secret police files were used in several former Communist countries, especially Germany (former GDR), Poland and Romania. 


\section{Archives and the duty to remember}

Throughout the world, memory has become a central cultural and political issue in our contemporary societies (Waldman, 2006). Archives have been swept along by the wave with thought rarely being given to the implications involved (Millar, 2006). Memory policies, or to be more accurate, policies for dealing with the past, are not the same thing as archival policies. Memory policies tend to be produced in the short term, whereas most archival policies are long term, often designed for stability to guarantee the trustworthiness of records, which need to be sustainable and neutral for credibility and evidential value reasons. There are, however, a number of authors who would have archivists reconsider the whole concept of memory,

ponder not only on how archives keep records of the past but also how, in their discourse and practices, they help to preserve a certain concept of what "the past" means. Archivists are asked to entertain the possibility that multiple perspectives are permissible of what "the past" might mean in the context of archival practice.

(Brothman, 2001)

Much of the confusion has been created by the fact that the new archival institutions set up to manage fonds that are more directly linked with human rights violations have frequently morphed into Memory Institutes or Centres. The links created, as a result, between archives and institutions set up for the purpose of harnessing public memory policies have cast doubts over the credibility of archives, especially when memory policies are known to have undergone a complete political about-turn. The questions all this begs are illustrated in Part 2, Chapter 9 by José M. Faraldo (on former Communist regimes in Central and Eastern Europe) and in Part 2, Chapter 13 by Ramón Alberch i Fugueras (on Colombia).

The problem of archives and memory is, however, nothing new in our profession. Much has been written on the subject and some of the insights offered are both thought-provoking and compelling. Excellent examples may be found in Barbara Craig's review essay (2002) on some of the major writings of historians, sociologists or philosophers, who have addressed 
the issue of memory and its pertinence to archives. While there may be major differences between these two concepts, it remains true to say that almost all archiving professionals have had the satisfaction, at some point in their careers, of comparing archives and memory by using the metaphor of archives as collective memory for discussing the social and cultural role of archives in our societies, by comparison with individual memory in our personal lives (Foote, 1990). It goes without saying that memory and archives are two different phenomena. Their apparent commonalities appear to be, to some extent, associated with the use of these two terms in computer science, where the words "internal and external memory" refer to places where documents are stored. The problem is that, in our everyday lives, human memory and computer memory have very different connotations, especially with regard to the ability to forget or deliberately suppress. Archives, as institutions, are not allowed to forget or suppress information of historical value, because this would harm possibilities of ever being able to analyse the facts in full.

Records and archives are not in themselves "memories", but only touchstones upon which memories may be retrieved, preserved and articulated. Laura Millar (2006) reminds us that records and archives are among countless different devices used in the process of transforming individual memories into collective remembering. Records, along with stories, artefacts, songs, rituals, traditions and myriad other non-documentary touchstones, are used to shape memories into narratives and to transform information and recollection from the individual to the collective. Nevertheless, as tools for retrieving or creating collective memory, archives play a major role in the struggle of man against forgetting and in the search for the truth. This has been recognised by a number of organizations, not least those for the defence of human rights. For archives are not just tools for memory but antidotes to forgetting (Millar, 2006).

Colombia's National Centre for Historical Memory, which was set up in 2011, is a useful reference, because in its mission statement, it clearly mentions archives as a tool for building plural memories and for securing the truth. The Centre is a public entity attached to the Department for Social Prosperity (Departmento Administrativo para la Prosperidad Social DPS), the purpose of which is to collect and retrieve all documentary material, especially oral and other personal testimonies connected with the violations mentioned in Article 147 of the Victims and Land Restitution Law (Ley de Víctimas y Restitución de Tierras). The information collected is to be made available to interested parties, researchers and the population in general. The Centre's role is to contribute towards providing full reparation and ensuring that the victims themselves and society in general enjoy the right to know the truth. It also has the role of enabling the State to fulfil its duty of remembrance to the victims of violations during the Colombian conflict in order to achieve the ultimate goal of peace, democracy and reconciliation. 


\section{Archives and the duty to remember}

In political transitions from totalitarian, repressive or dictatorial regimes towards democracy and in efforts to rise above domestic armed conflict, Memory institutes, centres or Archives are bound to be a recurrent feature of the process as they try to combine creating memory with the combat against oblivion and the search for truth. The first decade of the 21st century has seen major changes in legislation and the creation of institutions to manage archives or deal with the past, for example Memory Archives and Museums. Nearly all transitional countries in Central and Eastern Europe have passed laws on the archives of the former State security services. These regulations were extremely prolific in the case of the new institutions, defining conditions for the use of records, either through standards specific to archives or through provisions governing archival fonds included in more general legislation on memory or on dealing with the past. 


\section{Archivists for human rights}

In catering to the massive and unprecedented influx of police and intelligence service records from former dictatorships, National Archives in countries newly on the road to democracy were often handicapped in their efforts to preserve this vulnerable documentary heritage by the unfamiliar problems they faced with regard to its processing and access. In 1993, at the International Conference of the Round Table on Archives ${ }^{37}$ (CITRA) in Mexico, a group of experts was tasked by UNESCO and the International Council on Archives with drafting a report on the management of the archives of the security services of former repressive regimes. The group, headed by Antonio González Quintana, delivered its report in 1995. This underlined the fundamental role of these archives in guaranteeing citizens their collective and individual rights, because police files used to keep people under duress were, ironically, the best weapons for ensuring individual rehabilitation and collective reconciliation.

The report's final recommendations included the collective rights of people to all aspects of their memory, to truth, to know those responsible for crimes against human rights and the individual rights of victims and their families to know the whereabouts of vanished family members, to rehabilitation, to know what information is held on them, to amnesty in the case of political prisoners and to reparation and return of confiscated goods.

The Joinet and González Quintana reports were authored by experts with two completely different profiles: one coming from a legal, the other from an archival perspective. These reports were drawn up completely independently of each other, yet they came to exactly the same conclusions, albeit worded slightly differently. The extraordinary convergence between the magistrate's findings and those of the archivist went more or less undetected, the two professions tending to work in silos. Most archivists ignored the existence of Louis Joinet's report, even those in France who had heard of Joinet but only in a strictly national context. ${ }^{38}$ The González Quintana report, for its part, was published as an official document in English in hard and soft copy versions by UNESCO. ${ }^{39}$ It was also published in French in Janus, a professional journal with limited circulation. Outside a small group of archivists with an interest in international issues, very few people knew 
of its existence, even though it addressed a highly topical subject relevant to the public as a whole in many countries.

It was only in 2003, in Cape Town, South Africa that, for the first time, the notions of archives and human rights were addressed together at an international conference. This Conference was organised exclusively for the Directors of National Archives and the Presidents of National Associations and Sections of the International Council on Archives (ICA) and was the occasion for leaders of the profession to discuss strategic issues. Within the ICA, which is an international organization funded by countries, not all with democratic regimes, the question of human rights has always been a particularly sensitive issue, the expression "human rights" in itself carrying activist connotations upsetting to certain members of the profession.

Earlier meetings had been held in Latin America and in Central and Eastern Europe in response to demands from historians for access to these new sources of information. They also reflected the determination of human rights campaigners to contest the amnesty laws introduced by certain governments and insist on accountability so that reparations could be obtained (González Quintana, 2009, pp. 31-32). These events were local or regional in nature and the ICA was not involved.

The invitation from South Africa to host the 2003 Conference was an ideal opportunity to address the issue of archives and human rights, not least following the outstanding efforts of the country's Truth and Reconciliation Commission and the recent transfer of its records to the South African National Archives. For the archival community, the conference was a flagship event and the words of Desmond Tutu, Chairman of the Truth and Reconciliation Commission and winner of the Nobel Peace Prize, in his inaugural speech remain engraved in our collective memory:

We are ashamed of that part of our history, but it is our history nonetheless. And it stands there recorded in our National Archives.... The records are crucial to hold us accountable. . . They are a potent bulwark against human rights violations. We must remember our past so that we do not repeat it.

(ICA, 2004)

The Cape Town Conference played a decisive part in driving home the links between archives and human rights and the vital role of archives in transitional societies as instruments for the defence of individual and collective rights in countries formerly the scene of gross human rights violations. It also clearly revealed the need to recognise the vulnerability of such records and to adopt a professional approach to their curation. The conference concluded with a series of resolutions intended for the public authorities and international organizations, urging them to ensure that archival fonds providing documentary evidence of crimes committed were preserved and held in safekeeping, in particular records of State security services, police, truth 
and reconciliation commissions, international criminal courts and tribunals, international human rights defence organizations and non-governmental organizations. These national and international bodies were also urged to publicise the existence of and facilitate access to this material.

Another decision concerned the creation of a small working group on archives and human rights within the ICA to follow up on the Conference resolutions and maintain the momentum thus created. During the Conference, one of the things to have been brought into focus was the extent to which different professions tended to work in splendid isolation, in ignorance of what was happening in other sectors: society knew little of the world of archives and, at best, thought of them in purely cultural and heritage-related terms, while archiving was traditionally a low-key profession. The working group decided, therefore, to embark on a number of initiatives geared towards alerting public opinion, human rights defence protagonists and archivists.

The 1995 report on the archives of security services required updating and needed to be extended to take account of the latest considerations. A new document was, therefore, published by Antonio González Quintana in 2009 under the title Archival policies in the protection of human rights. This no longer focused exclusively on police and intelligence service archives but also included the archives of transitional justice institutions (extra-judicial commissions of inquiry and international criminal tribunals) and those of human rights organizations.

The report makes the case for comprehensive archiving policies treating all official documents in a professional manner and also supporting private archives. It urges the public authorities to take action to ensure that archives relating to periods of oppression are preserved and used under conditions guaranteeing their physical safety and to introduce legislation and regulations to protect the interests of the State and the individual. It also insists on the need for National Archives to be provided with the necessary human and material resources.

Communication activities were also stepped up and, since 2008, the group has been publishing a monthly newsletter ${ }^{40}$ giving national and international information and announcing recent or upcoming publications in the field. The newsletter is widely circulated and readers are encouraged to share its content. There are three language versions (English, French and Spanish) that can be downloaded from the ICA website. ${ }^{41}$

Efforts have also been made to make the preservation and processing of these archives more professional from the outset in low-resource organizations through the publication of a guide entitled "The records of NGOs: memory to be shared", which exists in several languages, including English and French, ${ }^{42}$ and the development of an open-source application for standardsbased archival description and access in a multilingual environment that rejoices in the name of AtoM (Access to Memory) and is designed to explain and simplify the process of uploading archival holdings. ${ }^{43}$ A number of 
studies have been published by Trudy Huskamp Peterson: a guide to preserving records of truth commissions (2005), a report on the records of the international criminal tribunals (2006) and a guide to securing police archives (2013).

Various events have been organised to inform governments, civil society and the international community of the political, legal, historical and memorial challenges these archives represent and the risks to which they are exposed. Encounters between archivists, human rights advocates and the legal profession have proved highly fruitful and have rapidly been translated into action. Through the intermediary of Louis Joinet, contacts established with the Office of the High Commissioner for Human Rights and the Human Rights Commission have enabled the wheels to be set in motion in the United Nations to obtain due recognition for the importance of archives in relation to the right to truth and have made it possible for the recommendations and guidelines mentioned earlier to be adopted.

On a parallel to these developments, the closing years of the 20th century and the early years of the 21st century were marked by the number of major contributions to critical thinking on this subject produced in academic circles. Many of them were the work of professors and archivists in different parts of the world, all proponents of the latest schools of archival thought, such as postmodern archival theory, resolutely in favour of changes in the role of the profession.

John Ridener (2009) provides a comprehensive overview of the changes in archival theory from the publication of Muller, Feith and Fruin's "Dutch Manual" in 1898 up to the period he calls "Questioning", which he addresses in his final chapter. For Ridener, this period may be situated between 1991 and 2004 and revolves around five archivists: Brien Brothman (1993), Terry Cook (1997), Carolyn Heald (1996), Eric Ketelaar (2003) and Laurie McNeil (2003). Other names should perhaps be added to this list, for example Tom Nesmith (2002) and Verne Harris (1997). The fathers of postmodern archival theory and, to an even greater extent, their successors argue in favour of the absolute need for activism in Archives as institutions but also, more importantly, for activism among archival practitioners. They argue that these institutions and those that work in them should transform archives into instruments of social justice, irrespective of traditional guidelines centred on the best preservation of official records. Consequently, they consider that it should be up to the rest of society to decide which records should be selected for permanent preservation. SouthAfrican archivist Verne Harris (2007) is probably the most outspoken advocate of this approach.

But postmodern archival theorists were not the only professionals involved in this major rethink of the purpose of archives and records. Archival organizations and many archival institutions have therefore cast themselves in a new social role, first and foremost in highlighting the importance of records and archives for guaranteeing individual rights and the 
administrative transparency of public organizations. In 1998, the nongovernmental organization Archivists without Borders (AwB) was founded in Barcelona. This soon spread with the creation of chapters in some dozen countries in Europe and the Americas. One of its primary objectives is that of preserving archives and documentary heritage relating to the gross human rights violations perpetrated in totalitarian countries and facilitating access to these records for victims and in the interests of justice. ${ }^{44}$ Its president and co-founder, Ramón Alberch i Fugueras, has highlighted the close links between preserving archives and the struggle for human rights (Alberch $\mathrm{i}$ Fugueras, 2008).

Other protagonists have taken up the cause and have been particularly involved in ensuring application of the Joinet/Orentlicher Principles and providing protection for these archives, a case in point being Switzerland. In 2011, the SwissPeace foundation joined forces with the Swiss Federal Archives and the Federal Department of Foreign Affairs to embark on a project called Archives and Dealing with the Past..$^{45}$ Swisspeace prefers the expression "dealing with the past" to that of transitional justice to underline the long-term nature of a process that is non-linear and requires complicated negotiations with a variety of other protagonists. A conceptual framework was established for this project and is based on the four pillars of the right to know, the right to justice, the right to reparation and the guarantee of nonrecurrence. ${ }^{46}$ The aim is to contribute towards ensuring that archives documenting human rights violations in transitional or post-conflict countries are suitably preserved and made accessible by establishing links between human right advocates involved in transitional justice processes and archival experts.

The foundation also provides a platform for exchanges of good practices for archival and transitional justice practitioners. Its website offers a very comprehensive list of international reference documents and a bibliography of works and articles published in this field. In 2017, it published a manual with the title Mapping Archives for Dealing with the Past Processes (Baumgartner and Peterson, 2017) which describes the stages involved in professionally mapping the archives needed for dealing with the past: where they are located, the information they contain, to whom they are accessible, identify the records at risk and the measures to be taken to secure them. This was based on the experiences of Tunisia's Truth and Dignity Commission Part 2, Chapter 3 by Adel Maïzi.

The Basic Principles on the role of Archivists and Records Managers in Support of Human Rights ${ }^{47}$ were produced by applying the approach adopted for the Basic Principles on the Role of Lawyers. For their part, the ICA Code of Ethics and the Universal Declaration on Archives, endorsed by UNESCO in 2011, establish a framework for the responsibilities incumbent on the profession but are couched in very general terms. The main purpose of these Principles is to support archivists faced with the complex ethical, legal and practical problems they are bound to encounter when dealing with 
records with human rights implications by providing them with helpful guidelines. Archivists often work in isolation and may be pressurised into destroying comprising documents or into omitting them from their finding aids.

Their second purpose is to help international officials dealing with human rights issues to understand the contribution that professional archivists and records managers can make to the protection of human rights. Some UN reports on human rights fail to mention the need to preserve archives and records. One classic example is the UN Guiding Principles on Business and Human Rights, otherwise known as the Ruggie principles (2011), named after John Ruggie, their rapporteur. Yet businesses need records managers to guarantee traceability, combat impunity and prevent abuse.

The Basic Principles encourage archivists to preserve the integrity of archives and their value as evidence of human rights violations and prevent their destruction, to consider the utility of a given body of archives to support human rights claims when selecting documents (identification of perpetrators of human rights violations, resolving the fate of missing persons or obtaining reparation), to waste no time and give priority to producing descriptions of such archival fonds, to afford access to these records for victims, even if they are not available to the general public (while being careful not to divulge confidential personal data) and not to make distinctions between prosecutors and defendants. ${ }^{48}$

They confirm that archivists who discover archives that contain evidence of gross human rights violations should inform the relevant authorities about the existence of such archives and Governments should provide them with channels to report such violations; and that they have the right to report to an appropriate authority any retaliatory measures or threats of retaliation in relation to the disclosure, provided that they have previously tried to use the existing internal reporting mechanisms. They should urge institutions to respect the cultural heritage of countries and communities and not acquire archives which do not fall within their jurisdiction. They should cooperate with institutions in other countries to settle claims about disputed displaced archives in a spirit of fairness and mutual respect.

In 2019, the working group was promoted to the status of ICA Professional Section, the Section on Archives and Human Rights (SAHR). This has the advantage of giving the group greater legitimacy and securing its financial resources as well as raising its profile inside and outside ICA. 


\section{Archives and human rights beyond political transitions}

In business circles, more needs to be done to promote the role of archives in defending human rights and in combatting impunity. As already mentioned, the UN Guiding Principles on Business and Human Rights, approved by the Human Rights Council in 2011, make no mention of the issue of access to records, although, without such access, it would be impossible to apply these principles and obtain redress (Barrientos et al., 2018). Archives are also vital in bringing the truth about human rights violations in the business world to light and offer the best sources of evidence of specific facts for use in imposing sanctions on the authors of violations and in making amends for the harm caused to victims.

These guiding principles are of crucial importance in obtaining business community endorsement of human rights. While it is not surprising that company owners and their shareholders would target profits, they may also be tempted to abuse the advantages offered by global, highly competitive markets by sacrificing their employees' social and economic rights and, in turn, weakening the foundations and wealth of a whole community and putting consumer health at risk. But, unlike the Joinet or de Greiff Principles analysed in detail earlier, the Ruggie Principles target the private sector, businesses first and foremost, which means that their application is largely dependent on the sector's willingness to play the game, because these principles do not have the same coercive force as for government institutions.

The Principles do, however, impose a variety of obligations on the States, for example that of ensuring that enterprises operating on their territory do not violate human rights or advising them on how to conduct their activities, when they operate largely abroad and in sectors wide open to violations, such as conflict zones, which places the onus squarely on government. Given the position of the victims of workplace human rights violations and the need to provide individual and collective channels for enabling them to seek redress, these Principles are also applicable to civil society organizations, such as Trade Unions, NGOs, victim associations and campaigners for human rights.

In 2017, in Geneva, the Human Rights Working Group of the International Council on Archives (HRWG) called the attention of the Forum 
responsible for monitoring application of the Ruggie Principles to the total absence of references to archives and recordkeeping in its document. Archives and records are crucial with regard to the right to know and the right to the truth in aiding governments to fulfil their supervisory role, and a key component of corporate policies and mechanisms for obtaining redress, in other words, all of the three areas covered by the Principles. The working group insisted on the importance of documents in ensuring application of these Principles to the following ends:

1 To provide States with objective information to help them fulfil the obligations incumbent upon them.

2 To provide businesses with evidence to demonstrate their commitment to human rights and deal with any eventual demands for redress they may receive under the reparations systems in place.

3 To afford civil society organizations and victims access to the documentary evidence they need to support their demands and stake their claims.

4 To help individual countries and individual businesses in drawing up action plans for implementation of these principles.

With regard to the first of these points, States must make sure that the records they produce in fulfilling their supervisory functions are preserved in the public archival system. For their part, businesses must make arrangements for their records to be properly handled to guarantee that they are held in safekeeping and can be retrieved and produced as proof of corporate transparency. NGOs and Trade Unions should also set up records departments, if only to keep track of the complaints made against businesses for abuses of human rights. Basically, archiving and archive management policies should be developed in the three areas just mentioned.

The need to document human rights violations in the business world was already mentioned earlier in a report of the UN Secretariat dated 2 July 2012 on the Contribution of the UN system as a whole to the advancement of the business and human rights agenda and the dissemination and implementation of the Guiding Principles on Business and Human Rights. The report states that "at the current time there is no global repository of information on patterns of business-related human rights impact and responses by States and business, as well as other stakeholders, to address such an impact". It is for this reason that it recommends the establishment of a comprehensive database to keep a record of "information on State initiatives and processes, corporate policies and practices, and the use of accountability mechanisms for affected stakeholders" and therefore proposes "the institutionalisation of a global repository on business and human rights within the United Nations". 49

The role of archives and records in the defence of human rights must also remain consistent in electronic environments. Computers and new technologies may offer enormous advantages in areas such as e-commerce, access to 
information and open government, but there remain issues with regard to document preservation and availability, authenticity and reliability that we cannot afford to ignore. While we may appreciate the ease with which soft copy material can be used, there is also the undeniable downside that this material is highly volatile and the information it contains extremely vulnerable. Maintaining and enhancing the capacities of archives and records for underpinning democracy and defending human rights in a digital environment is one of the biggest challenges facing us in today's new archival world. To cater to this challenge, the public authorities will need to ensure that the enormous benefits afforded by computer systems in boosting the efficiency, flexibility and transparency of their activities are, under no circumstances, allowed to undermine the democratic achievements of recent years in the preservation and accessibility of official documents and, by extension, their use by citizens as fundamental instruments for exercising their rights.

But while soft copy documents may be an undoubted boon in further underpinning democratic societies, the use of new technologies is also fraught with risk. Human rights advocates have two main concerns with regard to technological progress in respect of information and communications. The first concerns the risks inherent in the transmission systems in use and the possibility that the public or fiscal authorities may use these systems to spy on their citizens. It is not only the right to freedom of speech that is under threat through violation of our private communications but also our right to privacy and confidentiality. Their second concern is that the development of artificial intelligence could make humans superfluous to the administrative decision-making process through their replacement by self-executing routines.

Many international organizations have voiced their concerns over the issues of freedom of speech, the right to privacy and confidentiality. Their anxiety is largely triggered by the increasingly widely publicised scandals and accusations of abusive use of the possibilities for monitoring communications, and the employment of algorithms to track social media exchanges for purposes of developing individually tailored sales policies. They are also worried about the use of Internet to search for information or for business transactions. These perfectly justifiable concerns, prompted by the treatment reserved for private exchanges and the way personal data divulged by citizens is diverted for other purposes, have culminated in the adoption of data protection laws in over a hundred countries, plus international regulations with even broader scope. Among these, special mention should be made of the European Union's General Data Protection Regulation (GDPR), approved in 2016 and fully effective since 2018.

With the advent of the World Wide Web, document access has undergone a sea change, to the extent that many international human rights defence organizations see its use as a fundamental part of any democratisation process and consider that universal access to Internet and digital literacy are the only way of avoiding a truly unequal and unfair world. The Internet 
Rights and Principles Coalition, which is part of the UN Internet Governance Forum, has drafted The Charter of Human Rights and Principles for the Internet, ${ }^{50}$ in an attempt to adapt existing human rights to this new environment. The document states that "the Internet offers unprecedented opportunities for the realisation of human rights, and plays an increasingly important role in our everyday lives", adding that

It is therefore essential that all actors, both public and private, respect and protect human rights on the Internet. Steps must also be taken to ensure that the Internet operates and evolves in ways that fulfil human rights to the greatest extent possible".

Another of today's problems is that of environmental rights and their defence. Some of the best weapons when rising to the climate change challenge are open-source data, document management and transparency and the right of access to public sector information. In addition, the environmental disasters portended by climate change, with rising sea levels for example, may at times put archival buildings and records in jeopardy, especially if they are located in coastal areas. Both UNESCO and the International Council on Archives have embarked on initiatives geared towards locating such archives and evaluating the true extent of the potential risks they face. One example of these efforts is the "Survey for memory institutions, to measure the risks, damages and disasters in documentary heritage" compiled by the Secretariat of UNESCO's Memory of the World programme. ${ }^{51}$

A further complex issue is that of safe havens to be provided for archives at risk for reasons connected with wars or climate change. Following initiatives taken by UNESCO and Swisspeace, an international Working Group was established to draft Guiding principles ${ }^{52}$. These principles were issued in 2018 and later the same year approved by the ICA Executive Board. They are designed to proffer advice on the ethical and archival principles to be taken into consideration when transferring archives to other institutions for safekeeping.

One last point specifically concerns the defence of communities that are particularly vulnerable for reasons connected with their ethnic origins or economic circumstances. This is yet another massive challenge facing archives, not just as regards management of the records of the public or private sector organizations dealing with these communities (from the UN High Commissioner for Refugees to a significant number of nongovernmental organizations) but also as regards management of the many personal testimonies collected about violations of the rights of children, indigenous peoples, women or refugees. The Annual Conference of the International Council on Archives held in Adelaide (Australia) in 2019 focused on a number of major topics, one of the most important of which was the role of archives in protecting such communities..$^{53}$ This is but one of the latest developments within the ICA towards fully acknowledging 
the vital role of the archivist in relation to human rights because, as ICA President David Fricker writes in his introductory words to this book, "archives contain the evidence upon which the defence of human rights can be prosecuted".

\section{Notes}

1 In 1791, in response to the Declaration of the Rights of Man and of the Citizen, Olympe de Gouges drafted a "Declaration of the Rights of Woman and the Female Citizen", which she submitted to the National Assembly. The text was never discussed and, worse still, was not widely distributed at the time, partly because its author was sentenced to the guillotine two years later, in 1793, for having opposed the execution of Louis XVI. Olympe de Gouges was also one of the pioneers of the abolition of slavery, as evidenced by her play the Slavery of the Blacks of 1784, which was added to the repertoire of the Comédie Française in 1785 under the title Zamore et Mirza ou l'heureux naufrage. For a biography of Olympe de Gouges, see Faucheux (2018).

2 L'instauration d'un rituel civil, qu'on oppose au rituel religieux, a pour but de montrer qu'en déclarant son état-civil à l'officier municipal, un individu devient membre de la communauté des citoyens, de la même façon que le baptême supposait l'entrée dans la communauté des chrétiens [.. .] Le nouveau-né devra être "présenté" par ses parents à cette église laïque qu'est la "maison commune". C'est à partir de ces principes qu'est abordée la question proprement dite de l'identification des individus (Noiriel, 1993).

3 Transforming Our World: The 2030 Agenda for Sustainable Development, United Nations, A/RES/70/1, 2015.

4 The law was radically amended in 1974 following the adoption of the Privacy Federal Act.

5 Although, in Scandinavian countries, there exist more distant precedents with regard to the right of access to information, which date back to the 18th century, the first such law being the Swedish Freedom of the Press Act of 1766.

6 See Convention 205 of the Council of Europe on access to official documents published on 18 June 2009 and the model law on access to information of the Organization of American States adopted at the fourth plenary session held on 8 June 2010 - AG/RES. 2607 (XL-O/10).

7 Available at www.un.org/en/development/desa/population/migration/generalas sembly/docs/globalcompact/A_RES_60_1.pdf.

8 Case of Paniagua Morales et al., Verdict of 8 March 1998, para 173.

9 A/CONF.157/23.

10 C. Preservation of and access to archives bearing witness to violations: PRINCIPLE 13: Measures for the Preservation of Archives. The right to know implies that archives should be preserved. Technical measures and penalties shall be applied to prevent any removal, destruction, concealment or falsification of archives, especially for the purpose of ensuring the impunity of perpetrators of human rights violations. PRINCIPLE 14. Measures for Facilitating Access to Archives. Access to archives shall be facilitated in order to enable victims and persons related to claim their rights. Access should also be facilitated, as necessary, for persons implicated, who request it for their defence. When access is requested in the interest of historical research, authorization formalities shall normally be intended only to monitor access and may not be used for purposes of censorship. PRINCIPLE 15. Cooperation between Archive Departments and the Courts and Extrajudicial Commissions of Inquiry. The courts 
and extrajudicial commissions of inquiry, as well as the investigators reporting to them, must have free access to archives. Considerations of national security may not be invoked to prevent access. By virtue of their sovereign power of discretion, however, the courts and extrajudicial commissions of inquiry may decide, in exceptional circumstances, not to make certain information public if such publication might jeopardize the preservation or restoration of the rule of law. PRINCIPLE 16. Specific Measures Relating to Archives Containing Names. (a) For the purposes of this principle, archives containing names shall be understood to be those archives containing information that make it possible, in any way whatsoever, directly or indirectly, to identify the individuals to whom they relate, regardless of whether such archives are on paper or in computer files. (b) All persons shall be entitled to know whether their name appears in the archives and, if it does, by virtue of their right of access, to challenge the validity of the information concerning them by exercising a right of reply. The document containing their own version shall be attached to the document challenged. (c) Except where it relates to top officials and established staff of those services, information relating to individuals which appears in intelligence service archives shall not by itself constitute incriminating evidence, unless it is corroborated by several other reliable sources. PRINCIPLE 17. Specific Measures Related to the Restoration of or Transition to Democracy and/or Peace. (a) Measures shall be taken to place each archive centre under the responsibility of a specifically designated person. If that person was already in charge of the archive centre, he or she must be explicitly reappointed by special decision, subject to the modalities and guarantees provided in Principle 41. (b) Priority shall initially be given to inventorying stored archives and to ascertaining the reliability of existing inventories. Special attention shall be given to archives relating to places of detention, in particular when the existence of such places was not officially recognized. (c) The inventory shall be extended to relevant archives held by third countries, who shall be expected to cooperate with a view to communicating or restituting archives for the purpose of establishing the truth.

11 The Commission considered the report on 17 April 1998 (52nd meeting) and its resolution on impunity refers to it: C.H.R. res. 1998/53, ESCOR Supp. (No. 3) at 175, U.N. Doc. ECN.4/1998/53 (1998).

12 UN General Assembly, Resolution 61/177 adopted by the General Assembly: International Convention for the Protection of All Persons from Enforced Disappearance, 12 January 2007, A/RES/61/177.

13 Right to the Truth. Human Rights Resolution 2005/66, 20 April 2005.

14 Human Rights Council. Decision 2/105. Right to the Truth, 27 November 2006.

15 Commission on Human Rights. Study on the Right to the Truth, 8 February 2006. E/CN.4/2006/91.

16 Human Rights Council. Right to the Truth, 7 June 2007. A/HRC/5/.

17 Human Rights Council. Right to the Truth, para 4-31, 21 August 2009. A/ HRC/12/19.

18 Resolution adopted by the General Assembly on 18 December 2013. 68/165 Right to the Truth. A/RES/68/165.

19 Resolution adopted by the Human Rights Council, 13 October 2011. A/HRC/ RES/18/7.

20 ANNEX. "Set of general recommendations for truth commissions and archives". A: DE GREIFF, Pablo.- Report of the Special Rapporteur on the promotion of truth, justice, reparation and guarantees of non-recurrence. United Nations, 7 September 2015, A/HRC/30/42: Set of general recommendations for truth commissions and archives 
Introduction

1 Many post-authoritarian and post-conflict societies are faced with enormous challenges in the preservation and disposition of records containing information on gross human rights violations and serious violations of international humanitarian law. In many cases, secrecy, national security concerns, and poor archival practice stand in the way of guaranteeing the right to know the truth.

2 Archivists have, over time, developed sophisticated technical expertise and knowledge on all relevant issues regarding archives, including preservation, accessibility, and management. However, there is a striking gap between technical archival expertise and practice. Policies and practices that fall short of international standards risk the loss of records containing an important part of a society's heritage and hence hamper the possibility of accessing documentary evidence and support for efforts to achieve truth and justice.

3 Indeed, archives are relevant and can make significant contributions to each of the pillars of transitional justice, not merely truth and justice. At the same time, transitional justice measures can contribute to a country's archival system. Beyond the fact that transitional justice measures generate records themselves, truth commissions, trials, reparations programs and other transitional justice initiatives can contribute to improving archival practice both by the way they implement relevant standards with respect to their own documents, and because some of them, particularly truth commissions, are in a good position to make comments and recommendations about archival reform in general.

4 That potential, however, has not been consistently realized. Even truth commissions, both in post-authoritarian and post-conflict settings, manifest a significant gap between expertise and actual practice. There is little consistency in the disposition of truth commission archives, in the regimes that govern subsequent access to them, and in the recommendations that truth commissions make concerning archival systems.

5 In the conviction that these gaps need to be addressed, the Special Rapporteur on the promotion of truth, justice, reparation and guarantees of non-recurrence in his 2013 report to UN Human Rights Council on truth commissions (A/HRC/24/42) "calls for the development of international standards on archiving" for truth commissions. What follows is intended to contribute to the development of such standards. Part I contains recommendations for truth commissions pertaining to their own operations and the disposition of their archives, and Part II comprises recommendations that truth commissions can make regarding the establishment of national archival policies concerning records that contain information about gross human rights violations and serious violations of international humanitarian law.

a Both sets of recommendations build on well-established definitions on the "right to know" and on "archives" as stipulated in, among other places, the Updated Set of principles for the protection and promotion of human rights through action to combat impunity; see report of the independent expert Diane Orentlicher to update the Set of principles to combat impunity, E/CN.4/2005/102/Add.1, 8 February 2005.

$b$ For example, ISO 16363 defines a practice for assessing the trustworthiness of digital repositories.

6 As a general point, the Special Rapporteur would like to take the opportunity to reiterate the call on States to provide full support to truth-seeking mechanisms throughout their whole life-cycle, which includes access to records containing information on gross human rights violations and serious 
violations of international humanitarian law, in order for them to be able to effectively and independently implement their mandate.

\section{Recommendations for truth commissions}

In the context of their operations, truth commissions are encouraged to:

7 Build provisions for the eventual disposition of their records, guaranteeing both their safety and accessibility. This needs to be done in the early stages of planning their operations; a commission needs to decide who will be responsible for managing the records, where they will be stored in the short and long terms, and how access to them will be controlled.

8 Engage archival expertise in making and implementing those provisions during the life of the truth commission, and in this context take advantage of national (National Archives and Archival Associations) and international assistance and advice (e.g. International Council on Archives, Archivists without Borders);

9 Plan to deposit their archives in the country where the violations occurred and the commission operates, preferably in existing national archives, duly taking into account considerations of the security, integrity and accessibility of the archives. New and specialized archives may need to be created until such time as the national archives are able to adequately handle records of truth commissions. In the event of the possible loss, mutilation, poor preservation or destruction of the records in the country of origin, truth commissions should keep a complete, scanned and/or digitalized copy of the records in a secure facility outside the country or consider temporary preservation in a secure repository in a second jurisdiction or with an international institution;

10 Consider criteria having to do with preservation, accessibility, and trustworthiness of the host institution in deciding on the adequate repository.

11 Stipulate that the access policy of truth commission archives should maximize public accessibility, while respecting applicable privacy concerns, including in particular assurances of confidentiality provided to victims and other witnesses as a precondition of their testimony. Access to truth commission archives may not be denied on grounds of national security or other grounds unless the restriction is in full compliance with international human rights law;

12 Note that maximizing future accessibility has an impact on many operations of a commission throughout its lifetime, including, for example, on the process of taking statements and other contact with victims and witnesses who should be advised that their contributions to the commissions may be accessible in the future under specified conditions;

13 Establish guidelines for access to truth commission records, which shall take into account:

(a) General access rules, such as what was previously public should remain public; victims, families, investigative and prosecutorial authorities, as well as legal defence teams, should have unhindered access to information on their specific case; there should be a presumption of public access to all State information with only limited exceptions; a procedure to make effective the right of access should be established; whatever access rules are determined for various categories of potential users (for example, victims, legal representatives, journalists, academics, and members of the general public) should apply to all members of the given category without discrimination; 
(b) Categorization of records enabling familiar distinctions between types of documents (e.g. reports of own investigations, records of own meetings, victims' testimonies, documents obtained from other institutions, organizations, or private persons etc.) that will allow for a differentiated approach in facilitating access, in accordance with general access rules, to each type of document/collection;

(c) The need for effective mechanisms of reference services, as well as new technological advances in managing archives;

14 Develop, with the support of national and international expertise and assistance, provisions and measures to secure and preserve national archives, including by building effective and sustainable record management and archival systems, which includes, i.e., secure and adequate premises and clear appraisal policies;

15 Elaborate policies concerning relevant records and archives of non-State actors, including private businesses, so as to maximize effective management and access of these records by the truth commission.

II Possible recommendations by truth commissions

16 Regarding their recommendations on archives and the establishment of national archival policies that concern records containing information on gross human rights violations and serious violations of international humanitarian law, truth commissions are encouraged to:

17 Address the issue of reform of national archival legislation and institutions to encourage the establishment of modern, accessible, and reliable archives which are essential for the long-term preservation and use of records containing information on gross human rights violations and serious violations of international humanitarian law. Recommendations should include that reform efforts ought to be conducted with the participation of public institutions, civil society, and archival experts;

18 Make recommendations to preserve and actively use national archives, including archives of security services;

19 Call for independent oversight over the archives, including of archives of formerly repressive regimes;

20 Recommend the creation of archival laws, freedom of information legislation, data protection legislation and transparency requirements within other laws, which take into account the right to information, the right to know the truth, and the specificity of the records dealing with human rights violations and violations of international humanitarian law;

21 Recommend to the responsible authorities that they increase the capacity and where necessary the resources of State and local archival actors;

22 Recommend the provision by the State of information to the public on legal and practical requirements for access to archives;

23 Promote the establishment of comprehensive National Archival systems, including non-governmental records, especially those that are relevant to gross human rights violations and serious violations of international humanitarian law. Improvements in the regulation, disposition, protection and access to non-governmental archives (which does not involve the centralization of all records) will contribute to the establishment of such comprehensive systems, in accordance with international standards;

24 Recommend to the responsible authorities that they facilitate the work of civil society in the area of archives and ensure an enabling environment in this respect, in accordance with international standards; 
25 Reiterate that access to archives, containing records with information on gross human rights violations and serious violations of international humanitarian law, may not be denied to the public on grounds of national security unless the restriction is in full compliance with international human rights law.

21 Report of the Special Rapporteur on the promotion of truth, justice, reparation and guarantees of non-recurrence, para 80.12 October 2017. A/72/523.

22 Report of the Special Rapporteur on the promotion of truth, justice, reparation and guarantees of non-recurrence, para 49.25 July 2018. A/HRC/39/53.

23 "Rule-of-Law Tools for Post-Conflict States: Archives," United Nations High Commissioner for Human Rights series, 2015.

24 Decree 2726/83 of General Reynaldo Bignone. cf. Patricia Funes, Espionner, ficher, réprimer. La direction des services de renseignement de la police de la province de Buenos Aires et ses archives (Spy, record, punish. The Intelligence Services of the Police of the Province of Buenos Aires and their archives), La contemporaine, Matériaux pour l'histoire de notre temps 2006/1, no. 81, p. 105.

25 See the testimony of Red Brody (Human Rights Watch) in the film: Hissène Habré: La Traque d'un Dictateur (Canal+ France, 2009), And also in the Pierre Hazan's film: Chasseur de dictateurs. Article z, Arte, France, 2001.

26 The following institutions are part of the network:

1 Committee on Disclosure of Documents and Announcing Affiliation of Bulgarian Citizens to the State Security and the Intelligence Services of the Bulgarian National Army (Bulgaria).

2 Institute for the Study of Totalitarian Regimes and Security Services Archive (Czech Republic).

3 Federal Commissioner for the Records of the State Security Service of the former German Democratic Republic (Germany).

4 Historical Archive of the Hungarian State Security (Hungary).

5 Institute of National Remembrance Commission for the Prosecution of Crimes against the Polish Nation (Poland).

6 National Council for the Study of the Securitate Archives (Romania).

7 Nation's Memory Institute (Slovakia).

27 In Decree 5584 of 2005 , provision is made for the National Archives to collect the documents produced and received by the now defunct organizations that came under the authority of the Brazilian Intelligence Agency (Agência Brasileira de Inteligência): National Security Council (Conselho de Seguridade Nacional), General Investigations Commission (Comissão Geral de Investigações) and National Information Service (Serviço Nacional de Informações).

28 Kirsten Weld's essay Paper Cadavers (2014) is probably the best of its kind on the way these documents were recovered and used in Guatemala in the interests of human rights.

29 International Convention for the Protection of All Persons from Enforced Disappearances, Article 5: The widespread or systematic practice of enforced disappearance constitutes a crime against humanity as defined in applicable international law and shall attract the consequences provided for under such applicable international law.

30 Arns, P.E., dir. 1985, Um relato para a historia. Brasil: Nunca Mais. Sao Paulo: Arquidiocese de Sao Paulo, translated into English under the title, Torture in Brazil: A Shocking Report on the Pervasive Use of Torture by Brazilian Military Governments, 1964-1979. Austin: University of Texas Press, 1998. 
31 According to the online version of Encyclopaedia Britannica, the figure is "more than 35". Available at www.britannica.com/topic/truth-commission.

32 Law 21/2005 of 17 November on restitution to the Government of Catalonia (Generalitat de Catalunya) of documents seized during the Civil War kept at the General Archive of the Spanish Civil War (Archivo General de la Guerra Civil Española) and on creation of the Historical Memory Documentation Centre (Centro Documental de la Memoria Histórica).

33 In the original Spanish transcription, Barbie's alias was misspelled, the name under which he was known being Klaus Altmann Hansen and not Hausen.

34 Only in compensations to Holocaust survivors, Germany paid near 100 billion DM: "In September 1952 Adenauer reached agreement with Israeli Prime Minister Moshe Sharett to pay to Jewish survivors what would amount, through the years, to over DM100 billion" (Judt, 2005).

35 Principle 15. Housing, land and property records and documentation deserve a special mention:

15.1 States should establish or re-establish national multipurpose cadastral or other appropriate systems for the registration of housing, land and property rights as an integral component of any restitution Programme, respecting the rights of refugees and displaced persons when doing so.

15.2 States should ensure that any judicial, quasi-judicial, administrative or customary pronouncement regarding the rightful ownership of, or rights to, housing, land and/or property is accompanied by measures to ensure registration or demarcation of that housing, land and/or property as is necessary to ensure legal security of tenure. These determinations shall comply with international human rights, refugee and humanitarian law and related standards, including the right to be protected from discrimination.

15.3 States should ensure, where appropriate, that registration systems record and/or recognise the rights of possession of traditional and indigenous communities to collective lands.

15.4 States and other responsible authorities or institutions should ensure that existing registration systems are not destroyed in times of conflict or postconflict. Measures to prevent the destruction of housing, land and property records could include protection in situ or, if necessary, short-term removal to a safe location or custody. If removed, the records should be returned as soon as possible after the end of hostilities. States and other responsible authorities may also consider establishing procedures for copying records (including in digital format), transferring them securely and recognising the authenticity of said copies.

15.5 States and other responsible authorities or institutions should provide, at the request of a claimant or his or her proxy, copies of any documentary evidence in their possession required to make andlor support a restitution claim. Such documentary evidence should be provided free of charge, or for a minimal fee.

15.6 States and other responsible authorities or institutions conducting the registration of refugees or displaced persons should endeavour to collect information relevant to facilitating the restitution process, for example by including in the registration form questions regarding the location and status of the individual refugee's or displaced person's former home, land, property or place of habitual residence. Such information should be sought whenever information is gathered from refugees and displaced persons, including at the time of flight. 
15.7 States may, in situations of mass displacement where little documentary evidence exists as to ownership or rights of possession, adopt the conclusive presumption that persons fleeing their homes during a given period marked by violence or disaster have done so for reasons related to violence or disaster and are therefore entitled to housing, land and property restitution. In such cases, administrative and judicial authorities may independently establish the facts related to undocumented restitution claims. 15.8 States shall not recognise as valid any housing, land and/or property transaction, including any transfer that was made under duress, or which was otherwise coerced or forced, either directly or indirectly, or which was carried out contrary to international human rights standards.

36 The 187/1999 Lustration law would be declared unconstitutional by the Romanian Constitutional Court a few years later (Faraldo, 2018).

37 From 1954, CITRA organized gatherings in the interval between international Congresses for the Directors of National Archives and the presidents of national archival associations belonging to ICA. In 2013, it was replaced by a system of annual conferences open to all archiving professionals.

38 As a former Director of the National Commission on Computer Technology and Freedom (Commission nationale Informatique et Libertés - CNIL), Louis Joinet was no stranger to the world of archives.

39 Available at www.unesco.org/ulis/cgi-bin/ulis.pl?catno=140074\&set=005A58F0 8B_1_48\&gp=1\&mode=e\&lin=1\&ll=f.

40 Since 2009 , this newsletter has been produced by Trudy Huskamp Peterson, who chaired the group from 2009 to 2016.

41 Available at www.ica.org/en/hrwg-newsletters.

42 This practical guide consisting of 60 questions and compiled by Armelle Le Goff, in conjunction with the ICA's Section of International Organizations and prefaced by the UNESCO Director General, is intended for NGO managers and volunteers and its 30 odd pages offer basic advice on how to handle their records. It is available in eight languages on the ICA website. Available at www.ica.org/en/ records-ngos-memory-be-shared.

43 This is compliant with ICA standards (ISAD $(\mathrm{G})$, ISDF, ISDIAH, ISAAR (CPF) and designed specifically for the web. For further information, visit www.access tomemory.org/en/.

44 Available at www.arxivers.org/.

45 Available at http://archivesproject.swisspeace.ch/.

46 Available at http://archivesproject.swisspeace.ch/fileadmin/user_upload/archives project/Publications/DwP_Conceptual_Framework_October2012.pdf.

47 Basic Principles on the Role of Archivists and Records Managers in Support of Human Rights. Available at www.ica.org/sites/default/files/ICA\%20 HRWG\%20Basic\%20Principles_endorsed\%20by\%20PCOM_2016_Sept_ English.pdf.

48 Principle 15 of the Updated Set of Principles to Combat Impunity also states that "Access to archives should be facilitated, as necessary, for persons implicated who request such access for their defence."

49 Contribution of the UN system as a whole to the advancement of the business and human rights agenda and the dissemination and implementation of the Guiding Principles on Business and Human Rights. Report of the Secretary General, para 69 and 70.2, July 2012. A/HRC/21/21.

50 Internet Rights and Principles Coalition. The Charter of Human Rights and Principles for Internet. Internet Rights and Principles Dynamic Coalition (UN Internet Governance Forum), 2015. See also the resolution of the Council of Human Rights presented to the General Assembly of the United Nations: The promotion, 
protection and enjoyment of human rights on the Internet. United Nations document A/HRC/32/L.20, 2015.

51 The objective was to present the results of this survey at the 2nd Memory of the World (MoW) Global Policy Forum on Disaster Risk Reduction and Management for Sustainable Preservation of Documentary Heritage of UNESCO, which was scheduled to meet in Paris in October 2020 but was postponed until further notice due to the COVID-19 pandemic.

52 Available at www.ica.org/en/guiding-principles-for-safe-havens-for-archives-at-risk.

53 Designing the Archive. ICA Annual Conference Adelaide, South Australia, from 21 to 25 October 2019.

\section{Bibliography}

Alberch i Fugueras, Ramón. 2008, Archivos y derechos humanos. Gijón: Trea.

Arendt, Hannah. 1963, Eichmann in Jerusalem: A Report on the Banality of Evil. New York: Viking Press.

Banisar, David. 2006, Freedom of Information Around the World 2006: A Global Survey of Access to Government Information Laws. London: Privacy International.

Barahona, de Brito Alexandra, González, Enríquez Carmen, and Aguilar, Paloma, reds. 2001, The Politics of Memory: Transitional Justice in Democratizing Societies. Oxford: Oxford University Press.

Barrera, Giulia. 2011, "De cóndores y jueces: Reflexiones archivísticas sobre una investigación judicial,” Tabula, vol. 14.

Barrientos, Lizbeth, Bazaco, Blanca, González Quintana, Antonio, and Vega, Fernanda. 2018, "Los archivos en los Principios Ruggie y otros instrumentos internacionales contra las violaciones de derechos humanos en el mundo de los negocios," Informatio, vol. 23, no. 1, pp. 34-80.

Bassiouni, Cherif. 1999, Crimes Against Humanity in International Criminal Law. The Hague, Kluwer Law International.

— 2000, The Right to Restitution, Compensation and Rehabilitation for Victims of Gross Violations of Human Rights and Fundamental Freedoms. Final Report of the Special Rapporteur, Mr. Cherif Bassiouni, Submitted in Accordance with Commission Resolution 1999/33. Geneva: United Nations, Economic and Social Council, 18 January, E/CN.4/2000/62.

Baumgartner, Elizabeth, and Trudy, Peterson. 2017, Mapping Archives for Dealing with the Past Processes. Swisspeace. Available at http://archivesproject.swis speace.ch/resources/resource-collection/.

Bertrand, Jean-Wilfrid. 1988, "Les Archives nationales d'Haïti: près de deux siècles d'histoire, un nouveau depart," La Gazette des Archives, vol. 142-143, pp. 25-35.

Blazek, Peter. 2006, "Transitions to Democracy and the Lustration Screening Process," in: Transformation: The Czech Experience. Prague: People in Need with the Support of the Ministry of Foreign Affairs of the Czech Republic, pp. 173-180.

Borggräfe, Henning, Höschler, Christian, and Panek, Isabel. 2019, A Paper Monument: The History of the Arolsen Archive. Bad Arolsen: Arolsen Archives.

Brothman, Brien. 1993, "The Limits of Limits: Derridean Deconstruction and the Archival Institution," Archivaria, vol. 36, Autumn.

- 2001, "The Past That Archives Keep: Memory, History, and the Preservation of Archival Records," Archivaria, vol. 51. 
Cadelo, Valentina, and Peterson, Trudy H. 2018, "Principle 14: Measures for the Conservation of Archives"; "Principle 15: Measures for Facilitating Access to Archives"; "Principle 17: Specific Measures Relating to Archives Containing Names," in: Haldemann, Frank, and Unger, Thomas (eds.), The United Nations Principles to Combat Impunity: A Commentary. Oxford: Oxford University Press, pp. 163-180, 188-197.

Canavaggio, Perrine. 2014, Vers un droit d'accès à l'information publique: Les avancées récentes des normes et des pratiques. Paris: UNESCO.

Caso. 1998, El caso de España contra las dictaduras chilena y argentina: Los documentos del juez Garzón y la Audiencia Nacional. Barcelona: Planeta.

CIDH. 2015, Informe sobre la situación de los derechos humanos en la República Dominicana. Aprobado por la Comisión Interamericana de Derechos Humanos el 31 de diciembre de 2015. Comisión Interamericana de Derechos Humanos (CIDH). OEA/Ser.L/V/II. Doc.45/15. Available at http://www.oas.org/es/cidh/ informes/pdfs/republicadominicana-2015.pdf.

Cook, Terry. 1997, "What Is Past Is Prologue: A History of Archival Ideas Since 1898, and the Future Paradigm Shift," Archivaria, vol. 43, Spring.

Craig, Barbara L. 2002, "Selected Themes in the Literature on Memory and Their Pertinence to Archives," American Archivist, vol. 65.

Cruz, Luis M. 2010, "El derecho de reparación a las víctimas en el Derecho Internacional, Un estudio comparativo entre el Derecho Internacional de responsabilidad estatal y los Principios básicos de reparación de víctimas de derechos humanos," in: Revista de Derecho Político. $N^{\circ} 77$. Madrid: UNED, enero-abril.

Cunningham, Adrian. 2005, "Archival Institutions," in: Archives: Recordkeeping in Society. Cambridge: Chandos Publishing, pp. 21-50.

David, Roman. 2011, Lustration and Transitional Justice: Personnel Systems in the Czech Republic, Hungary, and Poland. Philadelphia: University of Pennsylvania Press, pp. 183, 209.

de Greiff, Pablo. 2013, Report of the Special Rapporteur on the Promotion of Truth, Justice, Reparation and Guarantees of Non-Recurrence. Pablo de Greiff: United Nations, 28 August, A/HRC/24/42.

- 2014, Report of the Special Rapporteur on the Promotion of Truth, Justice, Reparation and Guarantees of Non-Recurrence. Mission to Spain and Pablo de Greiff: United Nations, 22 July. A/HRC/27/56/Add.1.

- , 2015, Report of the Special Rapporteur on the Promotion of Truth, Justice, Reparation and Guarantees of Non-Recurrence. Pablo de Greiff, United Nations, 7 September, A/HRC/30/42.

- 2017, Report of the Special Rapporteur on the Promotion of Truth, Justice, Reparation and Guarantees of Non-Recurrence. Pablo de Greiff: United Nations, 12 October, A/72/523.

Doyle, Kate. 1999, "Death Squad Diary: Looking into the Secret Archives of Guatemala's Bureaucracy of Murder," Harper's Magazine, June.

Duchein, Michel. 1983, Obstacles to the Access, Use and Transfer of Information from Archives. RAMP Study, PGI-83/WS/20. Paris: UNESCO.

European. 2014, The "European Network of Official Authorities in Charge of the Secret Police Files" a Reader on the Legal Foundations, Structures and Activities. Berlin: BStU.

Faucheux, Michel. 2018, Olympe de Gouges. Paris: Gallimard. 
Foote, Kenneth E. 1990, “To Remember and Forget: Archives, Memory and Culture," The American Archivist, vol. 53.

González Quintana, Antonio. 1997, Archives of the Security Services of the Former Repressive Regime. Paris: UNESCO. Too in French in: Janus, 2. Paris: ICA, 1998.

—_ 2007, "La política archivística del Gobierno español y la ausencia de gestión del pasado desde el comienzo de la transición," Hispania nova, Revista de Historia Contemporánea, vol. 7. Generaciones y memoria de la represión franquista: un balance de los movimientos por la memoria 2007.

_ 2009, Políticas archivísticas para la defensa de los derechos humanos. Paris: ICA.

— 2011, "Documentos sin fronteras para una justicia universal," Justicia, terrorismo y archivos. Tabula, $N^{\circ} 14$. Salamanca: ACAL.

- 2019a, "La experiencia del Archivo Histórico de la Policía Nacional de Guatemala (AHPN) como referente del uso de los archivos en defensa de los derechos humanos," Historia, trabajo y sociedad, vol. 10.

— 2019 b, "El Archivo Histórico de la Policía Nacional de Guatemala, en la encrucijada," Archivamos: Boletín ACAL, vol. 113, p. 28, Septiembre.

Harris, Verne. 1997, "Claiming Less, Delivering More: A Critique of Positivist Formulations of Archives in South Africa," Archivaria, vol. 44, Fall.

$\longrightarrow$, 2007, Archives and Justice. A South African Perspective. Chicago. Society of American Archivists.

Hayner, Priscilla B. 2001, Unspeakable Truths Transitional Justice and the Challenge of Truth Commissions. London: Routledge.

Heald, Carolyn. 1996, Is There Room for Archives in the Postmodern World? Available at https://www.jstor.org/stable/40293954.

Hobsbawm, Eric. 1995, The Age of Extremes: A History of the World, 1914-1991. London: Abacus.

Huntington, Samuel. 1993, The Third Wave: Democratization in the Late Twentieth Century. Norman: University of Oklahoma Press.

ICA. 2004, Proceedings of the XXXVIIth International Conference of the Round Table on Archives (CITRA). Cape Town, South Africa: ICA, 21-25 October; Comma 2004.

IGA. 2016, Records Management Code of Practice for Health and Social Care. London: Information Governance Alliance (IGA).

Joinet, Louis. 1997, Question of the Impunity of Perpetrators of Human Rights Violations (Civil and Political). Revised Final Report Prepared by Mr. Joinet Pursuant to Sub-Commission Decision 1996/119. United Nations, E/CN.4/ Sub.2/1997/20/Rev.1, 2 October. Available at http://www.derechos.org/nizkor/ impu/joinet2.html.

— 2002, Lutter contre l'impunité: Dix questions pour comprendre et agir, dir. Louis Joinet. Paris: La Découverte.

Judt, Tony. 2005, Postwar: A History of Europe Since 1945. New York: Penguin Press.

Kaye, David. 2014, Archiving Justice: Conceptualizing the Archives of the United Nations International Criminal Tribunal for the Former Yugoslavia. Irvine: School of Law University of California, Legal Studies Research Paper Series No. 2014-34; Too in: Archival Science, vol. 14, pp. 3-4, October. 
Kecskeméti, Charles, and Székely, Iván. 2005, Access to Archives: A Handbook of Guidelines for Implementation of Recommendation R (2000) 13 on a European Policy on Access to Archives. Council of Europe. Available at https://book.coe. int/en/cultural-policies/3277-access-to-archives-a-handbook-of-guidelines-forimplementation-of-recommendation-no-r200013-on-a-european-policy-onaccess-to-archives.html.

Ketelaar, Eric. 1992, “Archives of the People, by the People, for the People," South African Archives Journal, vol. 34.

- 2002, "Tacit Narratives: The Meanings of Archives," Archival Science, vol. 1, no. 2, pp. 131-141.

Kitson, Simon. 2000, “Arresting Nazi Agents in Vichy France, 1940-1942,” In: Intelligence and National Security, p. 80, Spring.

Leitenberg, Milton. 2006, Deaths in Wars and Conflicts in the 20th Century. Ithaca: Cornell University Peace Studies Program.

Massaloux, Jean-Paul. 1989, La Régie de l'enregistrement et des domaines aux XVIIIe et XIXe siècles: Etude historique. Genève: Droz.

McNeil, Laurie. 2003, "Teaching an Old Genre New Tricks: The Diary on the Internet," Biography, vol. 26, pp. 24-47, Winter.

Mateva, Milena. 2006, Légitimité et Légalité. Considérations (sur la Loi et la Justice) à l'image de deux grands procès politiques [Procès Barbie - Procès Honecker]. Thèse présentée à la Faculté des sciences économiques et sociales de l'Université de Neuchâtel.

Millar, Laura. 2006, "Touchstones: Considering the Relationship Between Memory and Archives," Archivaria: The Journal of The Association of Canadian Archivists/Production, vol. 61, pp. 105-126, Spring, University of Toronto Press.

Noiriel, Gérard. 1993, "L'identification des citoyens. Naissance de l'état civil républicain,” Genèses, vol. 13, pp. 3-2.

Ollé Sesé, Manuel. 2009, “The Advance of Universal Justice,” FIDH, Spain Universal Jurisdiction, 27 May. Available at https:/www.fidh.org/en/region/europe-centralasia/spain/The-advance-of-universal-justice.

Olson, Laura. 2002, "Mechanisms Complementing Prosecution," IRRC, vol. 84, no. 845 , March.

Orentlicher, Diane. 2005, Promotion and Protection of Human Rights. Report of the Independent Expert to Update the Set of Principles to Combat Impunity, Diane Orentlicher, UN Doc. E/CN.4/2005/102, 18 February and Updated Set of Principles for the Protection and Promotion of Human Rights Through Action to Combat Impunity, UN Doc, 8 February. E/CN.4/2005/102/Add.1. Available at https://ap.ohchr.org/documents/alldocs.aspx?doc_id=10800.

Pérotin-Dumon, Anne. 2007, "Les archives de la défense des droits humains en Amérique latine: Chili, Argentine, Pérou," La Gazette des archives, vol. 206, pp. 45-94.

Peterson, Trudy H. 2005, Final Acts: A Guide to Preserving Records of Truth Commissions, Baltimore, MD: Johns Hopkins University Press.

- 2006, Temporary Courts, Permanent Records: Special Report. Washington, DC: United States Institute of Peace.

. 2011, "El valor probatorio del documento de archivo en los procesos judiciales," Tabula, vol. 14, Salamanca.

- 2014, The Probative Value of Archival Documents. Bern: Swisspeace. 
2018a, "Proof," Informatio, Revista del Instituto de Información y Comunicación, vol. 23, no. 1. Archivos y Derechos Humanos, Montevideo.

- 2018b, The Universal Declaration of Human Rights: An Archival Commentary. Paris: International Council on Archives - Human Rights Working Group.

Pinheiro, Sergio. 2005, Economic, Social and Cultural Rights: Housing and Property Restitution in the Context of the Return of Refugees and Internally Displaced Persons Final Report of the Special Rapporteur, Paulo Sérgio Pinheiro Principles on Housing and Property Restitution for Refugees and Displaced Persons. Geneva: United Nations, Economic and Social Council. E/CN.4/ Sub.2/2005/17.

Primera, Mayte. 2013, Medio millón de apátridas por una sentencia del Supremo dominicano; Los dominicanos hijos de haitianos, en el limbo entre dos sentencias: La sentencia que niega la nacionalidad a los descendientes de 'sin papeles' obvia un fallo de 2005 de la Corte Interamericana. Madrid: El País, 20, 22 de octubre de.

Ridener, John. 2009, From Polders to Postmodernism: A Concise History of Archival Theory. Sacramento: Litwin Books.

Rodríguez, Jorge. 2017, Derecho a la verdad y derecho internacional en relación con graves violaciones de los derechos humanos Madrid: Fundación Instituto Berg, año.

Ruggie, John. 2011, Guiding Principles on Business and Human Rights: Implementing the United Nations "Protect, Respect and Remedy" Framework. Geneva: United Nations, A/HRC/17/31, 21 March.

Salinas, Alejandro. 2005, Basic Principles and Guidelines on the Right to a Remedy and Reparation for Victims of Gross Violations of International Human Rights Law and Serious Violations of International Humanitarian Law Human Rights Resolution 2005/35. Geneva: Office of the High Commissioner for Human Rights.

Salvioli, Fabián. 2018, Report of the Special Rapporteur on the Promotion of Truth, Justice, Reparation and Guarantees of Non-Recurrence. Geneva: United Nations, 25 July, A/HRC/39/53.

- 2020, Memorialization Processes in the Context of Serious Violations of Human Rights and International Humanitarian Law: The Fifth Pillar of Transitional Justice. Report of the Special Rapporteur on the Promotion of Truth, Justice, Reparation and Guarantees of Non-recurrence. United Nations, A/ HRC/45/45, 9 July.

Sanford, George. 2005, Katyn and the Soviet Massacre of 1940: Truth, Justice and Memory. London and New York: Routledge.

Schiller-Dickhut, Reiner, and Rosenthal, Bert. 2014, 'European Network of Official Authorities in Charge of the Secret Police Files': A Reader on the Legal Foundations, Structures and Activities. Berlin: BstU.

Schrimm, Kurt, and Riedel, Joachim. 2008, "50 Jahre Zentrale Stelle in Ludwigsburg: Ein Erfahrungsbericht über die letzten zweieinhalb Jahrzehnte $=50$ Years Central Office in Ludwigsburg: An Empirical Account of the Last Two-and-a-Half Decades," Vierteljahrshefte für Zeitgeschichte, vol. 56, no. 4.

Schwartz, Herman. 1995, "Lustration in Eastern Europe," in: Transitional Justice: How Emerging Democracies Reckon with Former Regimes, vol. 1. Washington, DC: United States Institute of Peace Press. 
Schwartz, Joan M., and Cook, Terry. 2002, “Archives, Records, and Power: The Making of Modern Memory," Archival Science, vol. 2, pp. 1-19.

Svärz, Proscovia. 2009, "Archiving Challenges in Africa: The Case of PostConflict Liberia," IASA Journal: International Association of Sound and Audiovisual Archives, vol. 32.

Trial. 1947, Trial of the Major War Criminals Before the International Military Tribunal: Nuremberg, 14 November 1945.1 October 1946; Documents and Other Material Evidences (vols. XXV ....). Nuremberg. Available at https://www. loc.gov/rr/frd/Military_Law/pdf/NT_Vol-I.pdf.

Turrión, María José. 2013, "Políticas públicas de reparación en España: La ley 52/2007 sobre memoria histórica en relación a la identificación y localización de las víctimas desaparecidas durante la Guerra Civil y la dictadura," Alcores: revista de historia contemporánea, vol. 15, pp. 207-226.

UN-HCHR. 2006, Rule-of-Law Tools for Post-Conflict States: Prosecution Initiatives. HR/PUB/06/04. Geneva: United Nations High Commissioner for Human Rights.

. 2015, Rule-of-Law Tools for Post-Conflict States: Archives. HR/PUB/06/04. Geneva: United Nations High Commissioner for Human Rights.

United Nations, General Assembly. 2006, Basic Principles and Guidelines on the Right to a Remedy and Reparation for Victims of Gross Violations of International Human Rights Law and Serious Violations of International Humanitarian Law: Resolution Adopted by the General Assembly on 16 December 2005, 21 March. A /RES/60/147. Geneva: United Nations.

United Nations, Security Council. 2004, The Rule of Law and Transitional Justice in Conflict and Post-Conflict Societies. Report of the Secretary-General, 23 August. S/2004/616.

Van Boven, Theo. 1993, United Nations Commission on Human Rights: Study Concerning the Right to Restitution, Compensation and Rehabilitation for Victims of Gross Violations of Human Rights and Fundamental Freedoms: Final Report. Theo van Boven, Special Rapporteur, UN Doc. E/CN.4/Sub.2/1993, 8 July. Geneva: United Nations.

Waldman, Gilda. 2006, "La cultura de la memoria: problemas y reflexiones," Política y cultura, vol. 26, Otoño.

Weld, Kirsten. 2014, Paper Cadavers: The Archives of Dictatorship in Guatemala. Durham, NC: Duke University Press. 


\section{Part 2}

Case studies 
$\because$ Taylor \& Francis Taylor \& Francis Group http://taylorandfrancis.com 


\title{
1 Proof
}

\author{
Trudy Huskamp Peterson
}

"[U]nspeakable crimes have been committed in the name of the German people, calling for moral and material indemnity. . . . The Federal Government are prepared, jointly with representatives of Jewry and the State of Israel . . to bring about a solution of the material indemnity problem, thus easing the way to the spiritual settlement of infinite suffering."

Konrad Adenauer, speech to the Bundestag, 27 September $1951^{1}$

Property taken from Colombia's FARC guerrillas is to be used to pay reparations to FARC victims. ${ }^{2}$ More than 5,000 Kenyans who were tortured and abused during the Mau Mau uprising in the 1950s under British colonial rule received settlement payments. ${ }^{3}$ The residents of Guam want compensation for the damages suffered during World War II. ${ }^{4}$ Caribbean countries want reparations from their former European colonial masters. ${ }^{5}$ The calls to pay for past harms are heard on every continent. And even after the argument over whether to pay is settled, large questions remain: What are the criteria for payment? Who is within the group that will receive compensation? How will someone prove that he or she is within that circle? If the person who was within the circle is dead, will heirs be compensated? If so, how will they prove heirship? To answer all these questions and more, compensation decision bodies and claimants alike rely on records.

Money cannot replace love, friendship, dignity, and self-respect. Money cannot replace cemeteries obliterated, lands vaporized in a nuclear blast, or family photographs turned to ashes. But in the wake of great and terrible events, money can do some things: it can provide funds for living, buy prostheses, pay medical bills, support schooling, and rebuild housing. Perhaps most of all, money paid to persons who suffered acknowledges that harm was done. It moves personal knowledge of what happened into public acknowledgment of the damage.

* This essay was first published in the form of an article in the Informatio magazine (vol. 23, no. 1 of 2018) of the Faculty of Information and Communication of the University of the Republic of Uruguay. 
Compensation is one of the central elements of transitional justice systems. Some compensation is communal: building schools, constructing clinics, repairing or installing water systems. Some of it is commemorative: erecting monuments, holding ceremonies, adopting national or local holidays. And some is individual: regaining houses, getting support payments.

In his study of reparations, Roy L. Brooks identified five factors as prerequisites for a "meritorious redress claim":

(1) a human injustice must have been committed; (2) it must be welldocumented; (3) the victims must be identifiable as a distinct group; (4) the current members of the group must continue to suffer harm; and

(5) such harm must be causally connected to a past injustice. ${ }^{6}$

The second of these factors is an archival issue.

This chapter will look briefly at the historical background of compensation payments, and then consider the impact of World War II, the intellectual criteria for compensation developed by international bodies during the second half of the 20th century, and state-level compensation after 1975 to individuals who were harmed by state actions. Finally, it will consider the documents that serve as proof for the harm that gives rise to the right to compensation. It will not consider forms of individual compensation other than monetary, of which there are many: restoration of citizenship and civil rights, return of property (real or personal) or payment for property, and social services. Each of these is an important element of a comprehensive program to compensate for harm done, but they have different evidentiary needs than those for monetary compensation paid for harm to the person.

\section{Background}

Historically, two lines of compensation cases developed. In one line, states paid compensation for war damage as a state-to-state transfer of resources. Reparations were part of the world's protocols for postwar settlements; defeated powers made compensation in cash or kind. The 1907 Hague Convention Respecting the Laws and Customs of War on Land said, in Article 3, "A belligerent party which violates the provisions of the said Regulations shall, if the case demands, be liable to pay compensation. It shall be responsible for all acts committed by persons forming part of its armed forces." 7

How the receiving state went about using that compensation was entirely a matter of state decision. If the state had demanded compensation for damages done to private property, the state receiving compensation might, for example, pay the farmer whose land and crops were ravaged during a battle - but it was no sure thing. Some states undertook to indemnify their citizens themselves, as the United States did after the Civil War for Southern citizens who were Union loyalists and whose property was damaged during the Civil War. Such state compensation was for damage that could 
be assessed in monetary terms: buildings, land, sometimes for quantities of goods such as a merchant's stock. It was not for human pain and suffering.

A landmark case setting out the legal philosophy for compensation was decided after World War I by the Permanent Court of International Justice. The case involved a nitrate factory formerly in Germany that was now within the new boundaries of Poland and had been taken over by the Polish government. Germany sued for compensation and won. The court ruled that:

The essential principle contained in the actual notion of an illegal act a principle which seems to be established by international practice and in particular by the decisions of arbitral tribunals - is that reparation must, as far as possible, wipe-out all the consequences of the illegal act and re-establish the situation which would, in all probability, have existed if that act had not been committed. Restitution in kind, or, if this is not possible, payment of a sum corresponding to the value which a restitution in kind would bear; the award, if need be, of damages for loss sustained which would not be covered by restitution in kind or payment in place of it - such are the principles which should serve to determine the amount of compensation due for an act contrary to international law. ${ }^{8}$

The "essential principle" defined by the Court has been used ever since in international compensation cases. The decision, however, limited compensation to the commission of an act contrary to international law, not domestic.

The second line of compensation cases comes from individual litigation, not state-to-state settlements. For millennia people had turned to courts to recover, say, a missing sheep and, if it could not be returned, to be paid the value of it. Over time, courts also began to award compensation to people who were disabled by the action (or lack of it) of others. This often became a mathematical question, with compensation based on the length of time the person was injured and the loss of income that resulted. Wrongful death lawsuits also arose, as survivors sought to recover the monies that the deceased would have earned had he lived. Compensation for "pain and suffering" also developed, first as a component of disability claims and later with claims for the harm caused to a person by the death of a loved one. Finally, primarily in countries with a legal system based on English common law, after World War II courts began imposing punitive damages for harm, awarding large monetary settlements when the court found that the defendant's conduct was egregious and a heavy fine would help deter the offender from committing similar offenses in the future.

These cases for disability or wrongful death or pain and suffering involved private parties, either an individual suing another person or an individual suing a corporate entity, usually a business or manufacturer. The idea of that an individual could recover monetary damages from the government 
was not part of most lawyer's mental fabric before World War II. This stems, at least in part, from the doctrine of sovereign immunity, dating from the Middle Ages in Europe, which almost universally protected governments and their officials from being sued without their consent. A sovereign could, of course, magnanimously decide to award a form of compensation to one of his or her subjects and courts occasionally would entertain a limited suit against an official. But a right to sue to obtain recompense for harm caused by a government's policy or practice or by the act of a government official did not exist.

\section{The impact of World War II}

At the end of the war in Europe, the leaders of the USSR, the United States, and the United Kingdom conferred at Potsdam, outside Berlin. They issued a protocol on August 1, 1945, that formed the basis for the peace agreements with the European powers defeated in the war. Reparations issues were a contentious part of the discussions, and the three conferees finally agreed that the USSR would take reparations from the German zone it occupied, while the United States, the United Kingdom, and "other countries entitled to reparations" would take reparations from the Western zone, and all parties would take reparations from further unspecified "appropriate German external assets."

These were purely state-to-state reparations. The decisive break with the intertwined traditions of state-to-state repayment and sovereign immunity from private suits for damages by governments came with the post-World War II West German reparations to Jews. As Ariel Colonomos and Andrea Armstrong explained:

[T] he West German reparations program contained several new innovations: First, the reparations addressed both the Holocaust . . . beginning with the rise of Nazism in the 1930s, and the war against other countries; all preceding reparations had addressed the damages caused by war, exclusively. Second, they were negotiated by representatives of two countries, West Germany and Israel, which did not exist at the time the atrocities or the war took place. Third, these reparations compensated two categories of people: individual victims of the Holocaust, including citizens of the State paying reparations; and citizens of a new country, Israel. Fourth, also unprecedented, the negotiations included both representatives of states and nongovernmental organizations, such as international Jewish associations. Last, in contrast to the reparations following World War I, West Germany established this policy because Adenauer was convinced of its political necessity and of its just and moral character, and not necessarily because the FRG [Federal Republic of Germany] was held legally responsible. ${ }^{10}$ 
The first West German agreement on a Jewish reparations program was signed in 1952, but it had been preceded by a number of important steps. In 1947, the Allies required Germany to return goods that had been "aryanized," but they did not require compensation for the taking. Laws of compensation were promulgated in the British, French, and U.S. Zones of Occupation in 1949, which then became part of the Allied/German treaty ending the Western occupation in 1952. At that time, the Western Allies requested the German government to enact a law on reparations, which included two points important to the future mechanism of reparations: the law was to have "a procedural and evidentiary arrangement for restitution that takes account of the difficulties of proof resulting from persecution loss of documents, disappearance of witnesses" and "appropriation of funds to satisfy restitution claims." 11

On September 10, 1952, West Germany signed a compensation agreement with the new Government of Israel and the new Conference on Jewish Material Claims against Germany, a group created by 23 major Jewish national and international organizations to represent Jewish survivors outside Israel. Known as the Luxembourg Agreement, it stipulated that West Germany would pay 3 billion Deutsche Marks to the new state of Israel (Protocol I) and 450 million to the Claims Conference (Protocol II). Officially the money was all provided to Israel, which in turn paid the specified amount to the Claims Conference. The Claims Conference was to distribute the funds to individuals "according to the urgency of their needs." 12

Next the Federal Supplementary Law of 1953 established a basis for individual claims against the state if claimants could prove they had been targeted by "officially approved measures." ${ }^{13}$ Additional laws followed, including the key Federal Restitution Law of 1965 that established eight "fact situations indicating harm" that would make the person harmed eligible for compensation: (1) harm to life, (2) harm to body and health, (3) harm to freedom, (4) harm to possessions, (5) harm to property, (6) harm through payment of special taxes, fines, and costs, (7) harm to career advancement, and (8) harm to "economic advancement." 14 A sample of the application form used to establish a claim of "harm to body or health" is (in English translation) eight pages long, with such detailed questions as "Persecutee's average total income (not turnover!) from agriculture and forestry, small business, self-employed and non-self-employed work in the last three years prior to the beginning of the persecution that led to health damage" (underscore and exclamation mark in the original). No wonder the medical director of the Berlin, Germany, Center for the Treatment of Torture Victims said the details of the regulations were "impossible for laypeople to untangle and even something of a hieroglyphic for lawyers." ${ }^{15}$ But the sequence of laws was, quite simply, a legal revolution on the right to individual compensation by a state for actions of a state. 


\section{The international setting}

In December 1948, the United Nations adopted the Universal Declaration of Human Rights. The drafters, all scarred by the experience of the World War II, wanted to protect individuals and their rights, particularly those rights that were abused repeatedly during the war. The Declaration included, as Article 8 , "Everyone has the right to an effective remedy by the competent national tribunals for acts violating the fundamental rights granted to him by the constitution or by law," and as Article 17 (2), "No one shall be arbitrarily deprived of his property." ${ }^{16}$ Although referring exclusively to decisions by courts, a generous interpretation of Article 8 supported the right of compensation for the abysmal violations of human rights by the Nazi regime, whether or not specifically adjudicated. Article 8 also seemed to open the possibility of reparation for violations that did not relate to property, but it provided only remedies as provided by the government of the country in which the person was living. There was no apparent international recourse for harm that had not (a) occurred during a war, whether international or internal, regular or irregular, and was not (b) related to property whose financial cost could be assessed. ${ }^{17}$

Next, UN delegates began debating the elements to be included in the covenants that would provide a legal framework for the Declaration. Some delegates proposed including a procedure for individuals to submit petitions to any agency that might be created under the Covenant, but opposition quickly arose, including from delegates representing the three nations that met at Potsdam. No right to petition was included. ${ }^{18}$ This eliminated the possibility that an individual harmed by a state could look to UN bodies for help. The final language in Article 2 of the International Covenant on Civil and Political Rights said merely that each State Party must "ensure that any person whose rights or freedoms as herein recognized are violated shall have an effective remedy, notwithstanding that the violation has been committed by persons acting in an official capacity." ${ }^{19}$ This cracked the wall of sovereign immunity, but for all practical purposes, the impact of this language on international law was weak. Besides, the Covenant, although opened for ratification by states in December 1966, did not gain enough signatories to go into force until March 1976, showing the tepid support for its contents.

Starting in 1955 and every five years thereafter the United Nations held a "Crime Congress," an international assembly looking at standards for crime prevention and criminal justice. ${ }^{20}$ In 1985 , the Congress and the UN General Assembly adopted a Declaration of Basic Principles of Justice for Victims of Crime and Abuse of Power. It spoke to victims of crime and abuses of state power; importantly, it included "abuse of economic and political power." It obliged states to provide remedies for criminal violations by their employees and officials; it said that if a government is no longer in existence, the successor state must provide restitution and compensation. And in the case of "substantial harm to the environment," it required 
the offender (identity unspecified in the document) to "as far as possible" restore the environment, reconstruct the infrastructure destroyed, replace community facilities, and reimburse "the expenses of relocation, whenever such harm results in the dislocation of a community." The preamble called upon states to "promote disclosure of relevant information to expose official and corporate conduct to public scrutiny," an early signal of the problem of access to information that would bedevil courts of the 21 st century. The language of the Declaration was directed solely at Member States and, as usual with UN documents, included no enforcement mechanism. Still, it is another landmark in the movement toward individual compensation. ${ }^{21}$

But it wasn't enough. In 1989, as great political changes in Latin American and Eastern Europe were climaxing, the UN Commission on Human Rights, Sub-Commission on Prevention of Discrimination and Protection of Minorities, asked Dutch jurist Theo van Boven to undertake a study "concerning the right to restitution, compensation and rehabilitation for victims of gross violations of human rights and fundamental freedoms." 22 Van Boven filed a preliminary report in 1990 and a final report in 1993. Action on the report was slow. Van Boven and M. Cherif Bassiouni, a jurist who was a key proponent of an international criminal court, together revised van Boven's draft, and the Basic Principles and Guidelines on the Right to a Remedy and Reparations for Victims of Gross Violations of International Human Rights Law and Serious Violations of International Humanitarian Law finally was adopted by the UN General Assembly in December 2005, 16 years after van Boven began his work. ${ }^{23}$

The Right to Remedy principles provide a broad categorization of reparations measures: restitution, compensation, rehabilitation, satisfaction, and guarantees of non-repetition. It says compensation "should be provided for any economically assessable damage, as appropriate and proportional to the gravity of the violation and the circumstances of each case, resulting from gross violations of international human rights law and serious violations of international humanitarian law," such as lost opportunities, loss of earnings, and "moral damage." ${ }^{24}$ Including "moral" as well as monetary damage greatly widened the scope for compensation. States are responsible for providing reparation, which "should be proportional to the gravity of the violations and the harm suffered." However, in "cases where a person, a legal person, or other entity is found liable for reparation to a victim, such party should provide reparation to the victim or compensate the State if the State has already provided reparation to the victim." ${ }^{25}$ Echoing the provisions of the Set of Principles for the protection and the promotion of human rights through action to combat impunity that the Human Rights Council accepted in $1997,{ }^{26}$ the Right to Remedy principles state that

victims and their representatives should be entitled to seek and obtain information on the causes leading to their victimization and on the causes and conditions pertaining to the gross violations of international 
human rights law and serious violations of international humanitarian law and to learn the truth in regard to these violations. ${ }^{27}$

This appears to oblige non-state actors, including commercial entities, to provide reparation for harm, but whether they are also obliged to provide information is not clear from the text. And although the document once again links compensation only to violations of international law, by this time international law had taken on a new strength.

Between the time van Boven began drafting and the 2005 adoption of the Right to Remedy principles, several important advances had been made. The International Criminal Tribunals for the former Yugoslavia (1993) and for Rwanda (1994) and the International Criminal Court (ICC) had been established, ${ }^{28}$ and the statute of the ICC required the Court to develop "principles relating to reparations to, or in respect of, victims, including restitution, compensation and rehabilitation." Further, in 2004, the United Nations Human Rights Committee adopted a "General Comment" on The Nature of the General Legal Obligation Imposed on States Parties to the International Covenant on Civil and Political Rights. It focused on Article 2 of the Covenant, restating obligations and cautioning states to ensure that

individuals are protected by the State, not just against violations of Covenant rights by its agents, but also against acts committed by private persons or entities that would impair the enjoyment of Covenant rights in so far as they are amenable to application between private persons or entities..$^{29}$

With the intellectual framework for reparations to individuals fully developed and the international court system in pace, the rationale and a means for compensation for human injustice were in place.

In addition to these UN initiatives, regional bodies also began developing guidance and case law on the right to reparations during the second half of the 20th century. ${ }^{30}$ The Inter-American system was particularly active.

The American Declaration of the Rights and Duties of Man was adopted by an International Conference of American States in Bogota in 1948. Then in 1959, the Organization of American States (OAS), as the international group now was named, established the Inter-American Commission on Human Rights "to promote the observance and protection of human rights." The Commission was strengthened in 1969 when the OAS adopted the American Convention on Human Rights, which in Article 44 said, "Any person or group of persons, or any nongovernmental entity legally recognized in one or more member states of the Organization, may lodge petitions with the Commission containing denunciations or complaints of violation of this Convention by a State Party." ${ }^{31}$ This opened the door to 
individual complaints. Through the Commission, then, aggrieved individuals had a route to international adjudication of complaints against the state, although no complaints against non-state entities unless they could be linked to the state.

The same 1969 Convention established the Inter-American Court of Human Rights, which finally came into being on July 18, 1978, when the 11th OAS member State ratified the document. ${ }^{32}$ Both state parties and the Commission may refer cases to the Court, but the Court can only decide a case if it involves one of the 20 states that has accepted the Court's jurisdiction..$^{33}$ This provides individuals with a two-step path to adjudication: first a complaint to the Commission and then, if the Commission finds cause, from the Commission to the Court.

In an important case in 1989, the Inter-American Court ruled on compensation for the forced disappearance in Honduras of Angel Manfredo Velasquez Rodriguez. At the initial stage of the case before the Commission, the commissioners decided that the family deserved compensation from Honduras, including paying monetary compensation for income lost and making "an exhaustive investigation of the circumstances of the disappearance of Manfredo Velasquez and [bringing] charges against anyone responsible for the disappearance." The family appealed to the Court for moral compensation as well as monetary damages. The Court agreed and added compensation for moral damages to the amount calculated as the loss of earnings that Manfredo Velasquez would have provided to his family had he lived. The Court ruled, "[T] he obligation to indemnify is not derived from internal law, but from violation of the American Convention. It is the result of an international obligation." ${ }^{34}$

\section{National efforts}

While these significant international advances were being made in thinking about rights and compensation for wrongs, nations in the last quarter of the 20th century were grappling with the aftermath of mass violations of human rights and attempting to find means of redress. The national investigations were spurred in Latin America by the end of military dictatorships, in Eastern Europe by the demise of the communist governments, and in North America by social movements demanding acknowledgment that historic wrongs had been committed. These governments set about establishing the parameters for persons to be compensated and what proof the persons had to offer. The German example at the end of World War II was important to them, but often viewed as sui generis. Instead, national governments passed laws on compensation that were tailored to their national situations. The following are examples of the laws and regulations on compensation that were established by states, three each from Latin America, Eastern Europe, and North America. 


\section{Trudy Huskamp Peterson}

\section{Latin America: Argentina}

Argentina had a particularly long and complex program of compensation. ${ }^{35}$ After the restoration of democratic government, Argentina in 1986 passed Law 23.466 providing pensions for relatives of disappeared persons. It covered spouses and persons "living in consensual union for at least five (5) years immediately preceding the disappearance," disabled parents and siblings, and minor children of the disappeared. The disappearance must have taken place before December 10, 1983, and the claimant had to show that he or she had filed a complaint about the disappearance "with a judicial authority with jurisdiction, the former National Commission on the Disappearance of Persons, or the Office of the Undersecretary for Human Rights of the Ministry of the Interior." The payments were based on "the minimum amount awarded by the pension system for ordinary retirement to workers in the employ of another," but a separate amount was to be provided to disabled persons. Applications were filed with the Ministry of Health and Social Action.

The next year National Decree 1.228/87 was issued, regulating the application of Law 23.466 for pensions for minors whose parents had been disappeared. Its Article 1 specified that claimants had to submit an application form and the complaint that had been filed about the disappearance, and the "family relationships" of minors to the disappeared "shall be shown exclusively by the pertinent certificates or by judicial declaration" which were also to be submitted. If the facts of the original complaint were unclear, the applicant could submit the testimony of "two or more persons," and if the original complaint "cannot be provided by the applicant, the Secretariat of Human Development and Family shall collect it at its own initiative from the agencies mentioned." 36 The proof that the parents had lived in "consensual union" could be demonstrated "by any clear and convincing evidence showing that the persons in question were living together at the same address." 37

Next came Argentine Indemnification Law 24.043 of $1991,{ }^{38}$ titled "Benefits granted to persons placed under the control of the National Executive Branch during the State of Siege," covering persons who had been "placed at the disposition of the National Executive Authority prior to December 19, 1983" (Article 1) and civilians "having been deprived of liberty by acts of military tribunals, regardless of whether a guilty verdict was reached in the military jurisdiction" (Article 2). Applications were to be filed with the Ministry of the Interior to "verify compliance with the formal requirements" and confirm the duration of the prison term (Article 3). ${ }^{39}$

In 1994, Argentina returned once more to compensation for forced disappearances, passing Law 24.321 in May 1994 and Law 24.411 in December 1994. The implementing regulations in 1995 (National Decree 403/95) included a long list of requirements to prove a forced disappearance, the death of a person, and the existence of "consensual unions." 40 
All this became too much for the claimants (and, perhaps, also the government) to handle. Consequently, in 1997, the government issued Decree 205/97 "making the evidence required for receiving benefits more flexible." Now the evidence that would be accepted was as follows:

a Copy of the filing of the writ of habeas corpus or of the court's judgment on said writ

b Reports or certifications issued by a competent authority

c Documents in judicial and administrative files

d Documents at the Inter-American Commission on Human Rights of the Organization of American States and the Inter-American Court of Human Rights

In addition, the Ministry of Interior, which had authority to make the payments, would consider documents from "national and international human rights organizations, press articles and consistent bibliographic material." When the payment was for "grievous injuries," the applicant had to provide "at least one" of the following:

a Clinical records of the place of detention

b Copy of the judicial judgment that considered the detentions shown

c Medical or clinical records with the date corresponding to the period covered by the benefit, issued by an official health institution

d If necessary, a medical consultation

In all cases "the documents should be submitted with certification by the issuing authority."

Finally, in 2004, the government passed a law of compensation for "persons who were born during the deprivation of liberty of their mother or who, being minors, were detained under any circumstance in relation to either parent" who was detained or disappeared. To apply, a person had to present a birth certificate "and show, by any type of evidence" that the mother was "detained and/or disappeared for political reasons" and if born outside "prisons and/or captivity," the person had to provide "any type of evidence that they stayed in these places" and the detention and/or disappearance of the parent. The application was to be filed with the Ministry of Justice, "which shall in very summary form verify compliance with the requirements." The compensation was a one-time lump sum payment plus a monthly remuneration. If the person was one of the children whose "identity was changed," additional payments were authorized. ${ }^{41}$

By legislating repeatedly on the disappeared, Argentina's compensation program became exceedingly complex. It placed an onerous burden of proof on the claimants. The volume of records produced during its extended claims period must be enormous. 


\section{Trudy Huskamp Peterson}

\section{Latin America: Brazil}

In 1995, Brazil passed Law 9,140 recognizing “as deceased those persons who have disappeared because of participation, or accusation of participation, in political activities in the period from September 2, 1961, to August 15, 1979." 42 Appendix I of the law listed the people recognized as deceased "for legal purposes":

The spouse, male or female companion, descendant, ancestor, or relative to the fourth degree of the persons named on the list . . . who have proven this relationship, may petition the official of the civil registry ... to obtain a death certificate; this petition must be presented

when making a claim (Article 3). A Special Commission on the disappeared was created; one of its duties was to "issue opinions on the petitions regarding compensation by the spouse, the companion," descendants, ancestors, and "relatives to the fourth degree removed," all of whom could petition the Special Commission for validation. Article 7 says merely that such a petition "shall be accompanied with the information and documents that verify the assertion," and the Commission was empowered to request "documents from any public agency" as well as to ask the Ministry of Foreign Relations "to obtain information from foreign governments and organizations" (Article 9). The compensation was a single payment based on the life expectancy of the person who disappeared, to a maximum of 100,000 reais (Article 11). ${ }^{43}$

In 2002, Law 10,559 established a Commission on Amnesty to provide compensation for acts of "exclusively political persecution." ${ }^{44}$ It changed the final date for acts committed against the person to October 5, 1988, the date the new constitution was adopted, and two types of compensation were provided: one the lump sum payment and another a monthly compensation. Article 6(1) said the compensation to be paid would be "established according to the evidence provided by the applicant, information from official bodies, as well as from foundations, public or private companies, or joint enterprises under state control, orders, trade unions or professional councils." In a set of "frequently asked questions" posted on the website of the Ministry of Justice, the Commission, which still exists, said to apply for compensation a person must submit an "initial petition narrating the facts in detail, emphasizing the situations of political persecution and the damages caused by this situation" and also:
“a) Identity Card (RG);
b) C.P.F;
c) Marriage Certificate, if married;
d) Birth certificate of the child (ren); 
e) Proof of Residence;

f) Certificate of Reservation, if he is or has been military;

g) Proof of Bank Account;

h) Power of Attorney, if the application is filed by Attorney;

i) Electoral Title;

j) In case of death of the Amnesty, present the Certificate of Death;

k) Medical Report, if you are a carrier of any chronic disease;

1) Work Portfolio and/or Proof of Employment Bond, if applicable;

m) School History, if applicable;

n) Proof of Exile, if applicable; and

o) Other document (s) if necessary. Ex.: National Archives Certificate, State Public Archives Certificate, Employee Company Certificate (s), Witness Statement, Newspaper and Magazine Articles."

If the person who was subjected to persecution is deceased, the "dependents/successors" should submit a single joint petition for compensation. ${ }^{45}$

\section{Latin America: Chile}

Chile established a National Corporation for Reparation and Reconciliation in 1992, with a specific duty "to promote the reparation of moral damages" (Article 2). It was able to shortcut the decision on who would receive reparations by referring to Article 17 of Chile's first truth commission, the National Commission for Truth and Reconciliation (the "Rettig Commission"), which reported in 1991: "a monthly pension is hereby established for the benefit of relatives of the victims of human rights violations or political violence, who are named in the Second Volume" of the truth commission report. The monthly pension was to be a flat fee (Article 19); the beneficiaries were to be

the surviving spouse, the mother of the principal or his father if she has predeceased; the mother of the natural children of the principal or their father when the principal is their mother, and children under the age of 25 , or disabled children regardless of age.

The Health Service was to determine the child's disability (Article 20). Although this law neatly solved the "who is a victim" question, it left open the problem of proving who were relatives of the victim as well as the proof of medical condition. ${ }^{46}$

A second official truth commission in 2004-2005, called the "Valech Commission" after its chair, Bishop Sergio Valech, developed a greatly expanded list of persons who had survived torture or politically motivated detention by state agents during 1973-1990. Once again, persons who were on the Commission list as victims were given reparations. ${ }^{47}$ 


\section{Europe: Albania}

Albania in 1993 passed a Law on Former Victims of Persecution. Persons in five categories were eligible for compensation:

a Persons who have lost their lives or are mentally ill because of persecution

b Persons sentenced to imprisonment or who survived as outlaws within the country because of persecution

c Persons sentenced to internment or deportation because of persecution; Albanians with foreign citizenship, now Albanian citizens, who have lived in concentration camps especially built for them

d Persons who have lost civil rights, village kulaks, declassed persons, and those who have suffered privations of various kinds because of persecution

e Persons who, although fulfilling the conditions for inclusion in one of the preceding categories, do not gain the right to this status

For each of these five, the law then specified the "documents recognized for the right of this status" (Article 16). For example, for category (a), the claimant had to submit a "certificate from the Commission of the Ministry of Public Order and the Justice Ministry in cases in which a person had been killed or has died as a result of persecution" and a

legal and medical report from the time when the persecuted person lost the power of judgement because of persecution and a current legal and medical report showing that this situation is still true today or continued until the date of death, if the persecuted person is no longer alive. The degree of incapacity at which a person acquires rights under Paragraph (a) will be determined by a commission specially created for this purpose by the Ministry of Health.

The claim documents were to be

collected by the presidiums of the associations of former political prisoners and victims of persecution and the associations of former victims of political and economic persecution in neighborhoods, villages, and towns in cooperation with State inspectors for victims of political persecution in the districts, who will send them to the Committee for Former Victims of Political Persecution. This committee will collate them and submit them

to the state commission that would decide on eligibility for compensation (Article 17). The law warned that persons acquiring the status of victim "with documents legally proved to have been falsified, besides returning the sum they have unjustly obtained, will also be subject to criminal 
prosecution" (Article 19). With these strict criteria, one wonders how many people actually received compensation. ${ }^{48}$

\section{Europe: Bulgaria}

Bulgaria in 1991 passed the Law on Political and Civil Rehabilitation of Oppressed Persons. It established eight categories of persons eligible for "property and non-property damages" that occurred between September 12, 1944, and November 10, 1989 (Article 1). The successful claimants were to receive a lump sum payment, with "the amount and procedures of payment of compensation ... determined by the Council of Ministers.” "Appropriate written evidence" of unlawful oppression was to be submitted to the Council, and "if said written evidence is missing as a result of circumstances under previous regulations, its establishment shall be carried out by central and regional commission under procedures and in a composition determined by the Council of Ministers" (Article 4). The length of time persons were in forced "labor service" or were "interned, deported or resettled" was to be calculated, but without specifying what documents would be used in the calculation (Article 7). Heirs "of persons who died, committed suicide or disappeared in connection with forced changes of name shall receive a survivor's pension until such time as there is lawful basis for its termination" (Article 8). This was followed by a set of extensive regulations on amnesty for crimes and for restoration of confiscated property. ${ }^{49}$

\section{Europe: Russia}

A Russian law of 1991, amended in 1992, aimed "to rehabilitate all victims of political repressions on the territory of the RSFSR since 25 October 1917." Article 15 said that individuals "subjected to repressive measures in the form of deprivation of freedom and rehabilitated" will be "paid, on the basis of a certificate of rehabilitation, a monetary compensation of 180 rubles for each month of their incarceration, but no more than R25,000 out of funds from the republic budget." The compensation was to be paid within three years, and "no compensation is paid to heirs except in cases when the compensation was assigned but the rehabilitated individual did not receive it." Persons "who were repressed outside the borders of the Russian Federation but who permanently reside in its territory" can be compensated "on the basis of documentation concerning rehabilitation and time spent in prison which was issued in the States/former USSR Union republics or by State organs of the former USSR." Article 6 specified that applications could be submitted by "repression victims" or "by any other individuals or public organizations"; the applications were to be "submitted at the location of the organ or official who adopted the decision to apply the repression," which was either the "internal affairs organs" or the "procuracy organs." Article 7 required the internal affairs organs, after receiving an application, 
to "establish the facts" and issue a "certificate of rehabilitation." Further, "in the absence of documentary evidence of the fact of the application of repressive measures can be established judicially on the basis of testimony." Refusal by "internal affairs organs" to issue a certificate could be appealed to the courts. ${ }^{50}$ Submitting claims at the office of the repressor surely must have deterred some claimants.

\section{North America: Canada}

Compensation for the abuse endured by generations of First Nations children in Canadian residential schools took years and major litigation to resolve. In the 1870 s, Canada began to establish boarding schools to which aboriginal children were forcibly removed, with the goal of assimilating the children into European-Canadian life. Over 130 residential schools were established across Canada, and they endured until the last decade of the 20th century. Most of the schools were operated on the government's behalf by churches until 1969 when the government took over full control from the churches. The Indian Residential Schools Settlement Agreement of 2007 was a comprehensive resolution between former students, the churches, the Assembly of First Nations and other Aboriginal organizations, and the Government of Canada for the acknowledged harms.

The Settlement Agreement included five different elements to address the legacy of the Indian Residential Schools. One was a lump sum Common Experience Payment to each former student who had resided at a recognized Indian Residential School(s) and was alive on May 30, 2005..$^{51}$ The parties worked together to establish the roster of persons who were compensated; the government and the churches both researched records and provided evidence for the claims, supplemented by documentation provided by former students and First Nations organizations.

\section{North America: The United States}

In February 1942, two months after the December 1941 Japanese military attack on Pearl Harbor, Hawaii, U.S. President Franklin Roosevelt issued Executive Order 9066 directing the relocation of about 117,000 persons of Japanese ancestry, both citizens and non-citizen residents, from parts of California, Oregon, Washington, Arizona, Alaska, and Hawaii that were designated as military areas. The persons removed were housed in ten internment camps, the last of which closed in 1946. In 1988, after years of lobbying work by Japanese-Americans and the report of a Congressional commission on the wartime relocation, the government agreed to pay reparations to the relocated persons.

The Federal attorney general was directed to "identify and locate, without requiring any application for payment and using records already in the 
possession of the United States Government, each eligible individual.” An eligible individual was anyone

of Japanese ancestry who is living on the date of the enactment of this Act and who, during the evacuation, relocation, and interment period (A) was a United States citizen or a permanent resident alien; and (B)

(i) was confined, held in custody, relocated, or otherwise deprived of liberty or property

as a result of the wartime Executive orders and proclamations or who was recorded by the government as "being in a prohibited military zone" between December 7, 1941, and June 30, 1946. In addition, anyone could "notify the Attorney General that such individual is an eligible individual." Each eligible person was paid $\$ 20,000 . .^{52}$

Using records of the wartime camps held by the U.S. National Archives and a university as well as records compiled by Japanese-American organizations, the Justice Department contacted persons identified as eligible, asked them to verify their identity with a document showing a date of birth and, if the person had changed his or her name (such as a woman changing to a married surname), documentation of the name change. For persons who were "statutory heirs" of a person who was eligible but died between the enactment of the law and the date of payment, documentation was required of the deceased individual's identity, death, and a document showing evidence of relationship (marriage certificate for a deceased spouse, documentation of birth if a child, or evidence of guardianship) to each "eligible individual." ${ }^{53}$

\section{North America: The United States and the Republic of the Marshall Islands}

In the 1980s, the United States relinquished its Trust Territory of the Pacific Islands. Part of the territory became the Republic of the Marshall Islands (RMI): the location where the United States between 1946 and 1958 exploded 67 test atomic bombs. As part of the separation, the United States agreed to pay $\$ 150$ million to the new nation to be used "for the just and adequate settlement of all such claims which have arisen in regard to the Marshall Islands and its citizens and which have not yet been compensated in or which in the future may arise" resulting from the damage caused by the tests. ${ }^{54}$ The RMI government decided that any person who was living (including in utero) in the Marshall Islands at any time after June 30, 1946, or who was the biological child of a mother who was physically present (including in utero) in the Marshall Islands could claim, on the assumption that everyone had some degree of exposure.

The Tribunal established a list of medical conditions that - if the person had the condition - could be presumed to be caused by the nuclear testing 
and no further proof was needed. The claimant had to prove that he or she had the medical condition, however. If the person suffered from a condition that was not on the "presumed" list, the person had to show both that he or she suffered from the condition and that the condition was a result of the testing program. A Nuclear Claims Tribunal was established, which developed a claims form and sent staff members to many of the islands to help claimants prepare the claims. A 1989 statement of the rules of practice and procedure said, "[T]he Tribunal shall not be bound by the legal rules of evidence. . . . [T] he Tribunal will receive any evidence that is of a type commonly relied upon by reasonably prudent people in the conduct of their affairs" (Section 1000). It allowed people to submit copies of documents or "excerpts," saying that the "unavailability of an original shall not, in and of itself, make a copy inadmissible." The Tribunal also wanted a "certificate that it is a true and correct copy of the original," but noted that that requirement would be observed "whenever possible" (Section 1002)..$^{55}$

\section{Role of records}

Looking at the variety of compensation schemes already briefly described, it is evident that a successful claim always requires at least two types of proof: identity and harm. And for those proofs, records are needed.

\section{Establishing identity}

The claimant needs to show that he or she falls within the parameters of the group of victims to be indemnified. This begins with establishing identity. This may be the identity of the person who was the victim; it may be the spouse, the child, the parent; it may be a person acting on behalf of one of these persons. The proof needed is different in each case. It is easier for the state to assume the initial responsibility for identifying the persons within the group than to require documentation from the claimants. Some states, like Chile, have done this through a truth commission or, like Canada and the United States, through the government's own research. However, other states have placed the burden on the individuals, sometimes to a degree that makes it difficult for a victim to submit a successful claim.

Identity: Victim - States hold birth records and death records, records of identification cards issued which likely include a photograph, voter rolls, and records of tax payments. Some national governments have records of driver's license issuance, which may contain birth date and a photograph; social security or other identifications for pension benefits also may contain basic data on the individual. Police files on the person may have information on birth date and residence, photograph and fingerprints, perhaps results of a DNA test, and, if the person used an alias, may provide the link of alias to birth identity. If the person ever had a passport or visa, these would include birth date and a photograph, and even documents for temporary official 
exit from and entry to the country may include birth date and address and perhaps a photograph. Court records may show that the court determined the identity of victims, as the International Criminal Court's Trust Fund for victims did in the case of 297 victims of crimes committed by former Congolese militia leader German Katanga. ${ }^{56}$

Beyond government records, employers have personnel records that likely contain information on birth date, residence and length of employment, and may have a photograph (of course, if the person was ever employed by the government, the government would have these records also). Banks and credit institutions may have identification of account holders, as will insurance companies for policy holders; labor unions, membership rolls; faith-based institutions, records of affiliation. Media sources may have photographs or identification information, particularly if the person was prominent or notorious. Schools, especially primary schools, may have records showing birth date of the child, names of parents, and residence. If the compensation is in the wake of the work of a truth commission, a list of names may have been part of the records created by the commission.

DNA is increasingly important for determining identity. Governments have banks of DNA records taken from the population, either as a comprehensive program or as part of police or emergency or hospital cases. DNA may also help an illiterate person prove he is indeed who he says he is. Courts have generally held DNA identification as conclusive.

Private correspondence, social media postings, cell phone records, and personal photos all may be used to accumulate a picture of the person that would buttress claims of identity, if not be dispositive alone.

Some persons never had a birth certificate or similar document; ${ }^{57}$ others had these items but they were lost in flight or destroyed when a village was burned. Stateless persons and refugees may have only documents issued by an international organization, if they have any at all. In the absence of any evidence, as when the Kosovar refugees fled into Macedonia in 1999 and were stripped of all their documents by Serbian border control and with no access to the records in the Serbian government, the UN High Commissioner for Refugees resorted to having two persons testify that this is who the person is and then issuing a refugee identification card. This situation would be true as well for persons who lived in communities whose existence was not recognized and the persons were not given national identity cards, such as the Rohingya people within Myanmar.

Identity: Spouse - Showing kinship is a multistep process: first the person harmed needs to be identified (as mentioned previously) and then the identity of the claimant and the relationship to the person harmed must be verified. For a spouse, the state may have a marriage record or the faith institution that performed the marriage may have documentation. Again, pension records with an employer may show the spouse of the employee, as may insurance records or hospital records indicating next of kin or names on a joint bank account. Titles to property, such as a house, or a rental 


\section{2}

agreement or a mortgage or an insurance policy may have the name of both spouses. And if one spouse had a will, it might be held by a notary or by the lawyer who drew it up, listing the names of the heirs, including the spouse. If the couple had a child, a birth record or a hospital record may exist, but it may not include the names of both parents (in Afghanistan, for instance, the mother's name is not listed) or one name might be an alias. ${ }^{58}$

If the marriage is a common law arrangement, as accepted for compensation by Chile's "living in consensual union for at least five (5) years immediately preceding the disappearance," it might be proved by police records if one of the couple was under surveillance, or if the couple was formally renting housing, by the lease. However, if the couple was living in a squat or similar informal residence, there is unlikely to be a record of residence.

Changes of name are also an issue with spousal identity. When a woman changes her last name to include that of her husband, a government may record the transaction as, perhaps, may the faith-based organization that conducted the marriage. Two other name changes create more difficulty. First, if after the birth of a child a woman is known simply as " $\mathrm{X}$, mother of Y," a formula used in a number of cultures, that will not narrow the name to a single person without other information. Second, people in clandestine groups may take an alias, either a consistent nom de guerre or one that changes depending on the circumstance. In these cases, police records or military intelligence records may track the identity through the name changes and perhaps link the spouses.

Identity: Child or parent - If a claim by a child or parent is allowed under the law, many of the same records used for the spouse can be used here. Children can be identified from birth records, hospital and clinic records, school records, faith-based documents such as baptism records, perhaps insurance records, perhaps a will, perhaps refugee records where the birth indicated another ration of supplies. Personal documents can be useful, from videos and photographs of the family to email and social media chats.

When eligibility is extended beyond the immediate family, as it is in Brazil's "to the fourth degree removed" discussed previously, it becomes essential to understand the number of persons who might claim eligibility. If the compensation is to be extended to, for example, spouse and minor children of a deceased man who had four wives and each wife had four children, 20 claimants would need identity verification.

The DNA records that exist in government or medical databanks, in banks of DNA extracted from recovered remains and held by forensic archaeologists, or in commercial and genealogical DNA repositories can be matched with the DNA of a living person claiming to be a child or parent. It can also be used if the immediate relatives are deceased. Chile gave the DNA samples from persons whose family lost a member to a forced disappearance to the archives of the International Committee of the Red Cross, in the hope one day of being able to identify remains. Lebanon is undertaking a similar program. ${ }^{59}$ DNA may also be the only option to identify children who were 
found orphaned during a conflict and who were too young or too traumatized to remember the names of their parents or children forcibly removed from birth parents and adopted by others.

Identity: Representative - To prevent fraud, it is essential to prove that a person is authorized to act for another who is entitled to claim. The same is true if a social organization is claiming on behalf of an individual.

The identity of the representative is linked to questions of authority. After proving the identity of the person harmed, the guardian will need to demonstrate that he or she is authorized to act on behalf of the person. In the decree regulating pensions in Argentina for minors whose parents have disappeared, Article 1 said, "For the specific case of minors and other situations in which this benefit is to be collected through a representative, the nature of this representation must be shown by clear and convincing evidence." ${ }^{60}$ If the individual is illiterate or disabled, the guardian should have another person witness the document that authorizes the guardian to act on his or her behalf. That could be a notary or, in a refugee situation, an official of the organization managing the refugee facility, either of whom may keep a record of the transaction.

\section{Establishing harm}

Dead, disabled in any way, persecuted, imprisoned or exiled: all these are harms that some political systems have compensated. Each requires a different kind of proof.

Harm: Dead - As several of the national examples quoted previously show, death certificates normally must be obtained from the state. And while agreeing to record a missing person as dead is controversial in some situations, such as when families are reluctant to give up hope that the person did not perish, it is often a rigid requirement for compensation.

If a death certificate is not available, the records of hospitals, including police and military hospitals, and records of morgues and cemeteries can help verify the dead. In cases of death in police or military custody, unit records may contain evidence; in the infamous cases of persons pushed to their death from airplanes, military flight records may provide supporting evidence. Death in the custody of paramilitary groups may have little official documentation (unless, of course, the death was video recorded and posted on social media for propaganda purposes). In those cases, the testimony of witnesses will be the only available evidence.

Harm: Medical condition - Documenting the harm that resulted in a compensable medical condition may be difficult or at least complicated to prove. For example, part of the form to be completed by persons making claims under the German Restitution Law of 1965 for harm to body or health asks:

What ailments do you ascribe to persecution measures? (Exact information on appearance of bodily harm and disruptions it caused to working ability.) 
In your view, what special measures of persecution or what persecutioninduced circumstances caused the harm? (Provide the time period and precise description of events, indicating evidence.)

When did the ailments ... first appear? Ailment, time period.

How did the bodily harm become evident?

Are you under a doctor's treatment because of the bodily harm, or were you treated in a hospital (including infirmary or prison hospital)? From-, treated by whom or where (address), ailment, type of treatment.

What insurance carrier were you a member of? Prior to persecution, in; during persecution, in. What insurance carrier are you currently a member of, in?

Have you been evaluated or cared for by a health office, another official office, or at the behest of a social insurance carrier? In what time period? Where? For what reason?

When, where and because of what illness did you undergo medical treatment or therapy at the expense of health insurance carriers, insurance carriers, agencies, or at your own expense?

What illnesses do you suffer from, or what bodily injuries or health damage exists that you do not attribute to persecution? Description of illness, bodily injury or health damage, Starting when, Address of doctor or hospital where treated, Address of insurance carrier.

These questions, many of them nearly impossible for a person not traumatized to answer, were followed by questions on the personal and economic situation of the persecute, the spouse and the parents, including the requirement to "attach evidence (proof of income, tax return, etc.)." 61

Proof of harm resulting in a debilitating medical condition normally resides in medical records. In the best cases, claimants can obtain copies from the medical facility itself, often with a certificate of authenticity attached. But obtaining patient records is not easy. In war zones, hospitals, ostensibly protected under the provisions of The Hague conventions on the law of war now are often subjected to bombing, fire, and destruction, taking records blazing with them, whether stored in paper, on $\mathrm{X}$-ray film, or in computers. In the case of the Marshall Islands claimants, many of them were treated in hospitals in other countries: in Hawaii, in Manilla, in medical centers in the continental United States. Others were treated in Majuro, the capital, but the old hospital was razed and records were destroyed. And some people were treated in U.S. military or other secure government facilities who controlled the treatment records as sensitive if not classified; after much back and forth between the Tribunal and the government facilities, the Tribunal doctors were allowed to obtain crucial documents.

Also, there are locations where no medical facility existed and people were treated informally, if at all. Sometimes refugee and humanitarian 
organizations were able to reach these people and to some degree document their suffering; those records would be available if kept by the organizations.

Medical records are also complicated as proof because medical practice, terms, and diagnostic criteria have changed over the years. A diagnosis of a prisoner by a medical officer employed by a military hospital 40 years ago would not only need to be evaluated for bias (the patient was a prisoner) but also for the changes in categorization of, especially, mental conditions.

A further complication is that non-medical persons who sit on bodies making the compensation decisions find medical records difficult to interpret. The Nuclear Claims Tribunal had a medical officer review the records and make a report to the commissioners, rather than try to understand the medical terms, abbreviations, and conclusions in the records.

Harm: Prison, disappearance, and exile - The records of prison, disappearance, and exile are, as with death, largely in the archives of the government. Arrest records are with the police; abduction records sit in archives of military and police units, even if the information is said to have come from paramilitaries in league with the government. The duration of imprisonment may be documented through lists of persons held each day at a facility and records of feeding. Records of prison hospitals also provide dates when the individual was known to have been in custody.

Non-state actors may keep no records of persons captured and held, but it is also possible that there are internal records of prisoners. For example, ISIS sold women and children as slaves, and the records of those transactions have been found in their computers and in postings to electronic services. ${ }^{62}$

Records of trials, however hasty, and the resulting sentences are found in archives of civil and military courts. Some non-state bodies like ISIS also have used a form of trials, some of which are documented.

If the state is unable or unwilling to provide evidence of its actions, civil society groups and independent media may have documented disappearances and may have copies of judicial proceedings that were given to them by family members. In some cases, too, such as the Honduras case discussed previously, an international judicial body may have records that provide evidence. And, of course, families of the imprisoned and missing will often have personal items showing their concern, such as emails among family and friends asking anxiously if they know where the person is.

A particularly cruel provision in some state laws is to require the claimant in a case of disappearance to provide a copy of the filing of the writ of habeas corpus. Families of the disappeared in some countries, such as Chile, did indeed file petitions with courts seeking the release of the missing person. But once again this shifts the burden of proof to the family of the person and creates guilt if no petition was made and thus no documentation exists. 
Exile is documented by both the state expelling the person through a judicial proceeding and the state providing refuge. Court, border control, and transportation records could be useful; diplomatic records might have the arrangement with the country to which the person was deported. Families also are likely to have documents, including social media, showing the existence of the person in exile.

$* * * * *$

As demonstrated previously, many sources exist to establish an identity and prove harm and thereby support the demand for compensation. The state awarding the compensation, whether by a law or decree or through action of the courts, often possesses the information that can verify the claim. Adjudication of the documents before a claims body must have procedural fairness and should also be sensitive both to traditional forms of adjudication and to the emerging international legal consensus on appropriate methods to validate the links between the victim, the violation of the law, the harm that resulted, and the nature of the compensation (direct monetary loss and moral damage) that can be claimed.

Often the critical documentation problem is the unwillingness of the state to open the relevant records. Classification of records as secret and the exemption of military and police forces from government records laws (including freedom of information acts) severely hamper the fact-finding required in compensation cases. In the face of intransigent officials denying that records exist, and unless courts are willing to force the police and military to completely divulge their records, claimants will go through the excruciating process of assembling documents from other sources, including by taking sworn testimonies, in order to obtain compensation.

As a claims commission begins its work, the body needs to be sensitive to the requirements that proof places on archivists. For example, here is what the Government of Canada did to verify that former students resided at a recognized Indian Residential School:

1 A computer search is an automatic search of over two million documents which produces clear answers in about 40 per cent of cases.

2 If the computer search does not give a clear answer, a researcher must manually search through documents for each school named in the application in order to confirm eligibility.

3 If a manual search does not produce a clear result, the [authorities] will try to contact the applicant to find out more about their residential school experience. If the applicant can provide information, their answers will be compared with what is known about the school and life there to support the application. ${ }^{63}$

While the government did this search, other archivists researched the records of the churches who ran the schools. Claude Roberto, an archivist 
in Alberta, Canada, described the research done by church archivists for the truth commission that was part of the settlement package:

The Canadian government and religious organizations involved ... signed an agreement to support the activities of the [truth] Commission and make their records available to it. This agreement put archivists in an unprecedented and stressful situation requiring them to identify and make records available to the Commission. The agreement was written by lawyers of the commission, without consultation with archivists. Consequently the extent of the records to be reviewed and the amount of work to be done by archivists were largely underestimated.

Religious archivists photocopied records to protect their integrity and to prevent theft and tampering. They made information available and remained impartial in a climate of hostility and conflicting interests as well as cuts in institutional funding. Transparency was essential in institutions serving donors, including clergy members, and users such as the Commission. However archivists face ethical issues when requirements from Canon law conflicted with transparency. Archival standards and practices suddenly changed: the need to provide access became by far more important than other archival responsibilities and protection of privacy and intellectual property rights. ${ }^{64}$

\section{Conclusion}

The second half of the 20th century saw governments compensating other governments for the specific purpose of indemnifying their citizens: Germany began the practice, and it has continued into the 21 st century. In 2014, for example, France transferred $\$ 60$ million on the United States to compensate persons now living in the United States who were transported to World War II concentration camps on French trains. ${ }^{65}$

Sovereign immunity has eroded, with individuals suing governments for harm. Governments, in response, have agreed to settlements that acknowledge harm and provide monetary and sometimes moral indemnity. And some governments, particularly after a change in regime, have voluntarily developed compensation plans for categories of people harmed, such as families of the disappeared or persons unjustly incarcerated.

Governments are also being sued by individuals from another state who have been harmed by the actions of that state. For example, the Mothers of Srebrenica sued the government of the Netherlands for lack of protection by the Dutch peacekeepers in Srebrenica of their husbands and sons who were killed. ${ }^{66}$

Individuals are bringing abuse claims against governments to regional human rights commissions, especially the Inter-American and the European commissions, and through them to the respective Courts of Human Rights. Individuals can petition the UN High Commissioner for Human Rights to 
launch an investigation into an abuse, and the Commission can recommend that the International Criminal Court bring charges.

Today international corporations are often sued for human rights damages - to health, to environment, to community. Obtaining the documents for proof in these cases is difficult, whether the corporation is stateowned or private. Claimants find themselves facing corporations with closed corporate archives. In extractive industries or industries that manufacture products that harm health (and know the products are harmful), compensation cases arise from litigation brought by private individuals against the firm in national courts. While in some instances the persons harmed have, for example, personal medical records that document harm to health, the records of the firm are usually obtained through a laborious, expensive process of legal discovery. In a few instances, leaks from within the corporation or accidental document disclosures have played roles in the compensation cases. But until there is a more regulated means of obtaining relevant corporate documents in cases of violations of international humanitarian law or international human rights law, these claimants will not have a regular, assured document disclosure path to follow, nor will they have a clear path to adjudication in an international tribunal.

Be it in governments or non-governmental bodies or corporations, considerable effort is required to locate and make available the records that document harm. It is a burden that the institutions of state and private sector should shoulder. The preamble to the Basic Principles on the Roles of Archivists and Records Managers in Support of Human Rights, a 2016 official working paper of the International Council on Archives, says that "adequate protection of the human rights and fundamental freedoms to which all persons are entitled, be they economic, social and cultural, or civil and political, requires that all persons have effective access to archival services provided by independent archival professionals." Material and moral indemnity for grievous harm is essential. Only when that is paid can victims and victimizers, in Konrad Adenauer's words, begin "easing the way to the spiritual settlement of infinite suffering."

\section{Notes}

1 "History," The Conference on Jewish Material Claims against Germany. Available at www.claimscon.org/about/history/.

2 "Lista de bienes de las Farc va a Fiscalía, JEP y fondo para víctimas," El Tiempo, 17 August 2017. Available at www.eltiempo.com/politica/proceso-de-paz/a-quienesbeneficia-entrega-de-bienes-de-las-farc-120680.

3 The United Kingdom agreed to pay damages to 5,228 Kenyans for torture and abuse during the Mau Mau uprisings in the 1950s. "UK to Compensate Kenya's Mau Mau Torture Victims," The Guardian, 6 June 2013. Available at www. guardian.co.uk/world/2013/jun/06/uk-compensate-kenya-mau-mau-torture

4 "Guam World War II War Claims: A Legislative History.” Available at www. guampedia.com/guam-world-war-ii-war-claims-legislative-history/. 
5 Castle, Stephen. 2013, "Caribbean Nations to Seek Reparations, Putting Price on Damage of Slavery," New York Times, 20 October. Available at www.nytimes. com/2013/10/21/world/americas/caribbean-nations-to-seek-reparations-putting-price-on-damage-of-slavery.html.

6 Brooks, Roy L. 1999, “Introduction,” in: Brooks, Roy L. (ed.), When Sorry Isn't Enough: The Controversy over Apologies and Reparations for Human Injustice. New York: New York University Press, p. 7.

7 Convention Respecting the Laws and Customs of War on Land (Hague IV 1907). Available at www.lawofwar.org/hague_iv.htm.

8 Permanent Court of International Justice, Factory at Chorzów (Merits), Judgment of 13 September 1928, p. 47. Available at www.icj-cij.org/pcij/series-a. php?p1 = 9\&p2 = 1 .

9 Article 3, Protocol of the Proceedings of the Berlin Conference, 1 August 1945. Available at https:/history.state.gov/historicaldocuments/frus1945Berlinv02/ d1383. Only Article 13 mentioned documents needed to support compensation, oddly on oil equipment in Rumania: the parties "agreed to set up two bilateral commissions of experts, one to be composed of United Kingdom and Soviet Members and one to be composed of United States and Soviet Members, to investigate the facts and examine the documents, as a basis for the settlement of questions arising from the removal of oil equipment in Rumania."

10 Ariel Colonomos and Andrea Armstrong. 2006, "German Reparations to the Jews After World War II: A Turning Point in the History of Reparations," in: de Greiff, Pablo (ed.), The Handbook of Reparations. Oxford: Oxford University Press, p. 391.

11 Pross, Christian. 1998, Paying for the Past. Baltimore, MD: The Johns Hopkins University Press, p. 21.

12 Timm, Angelika. 1997, Jewish Claims against East Germany: Moral Obligations and Pragmatic Policy. Budapest, Hungary: Central European University Press, pp. 85-87.

13 Pross, op. cit., p. 39.

14 Pross, op. cit., p. 50.

15 Pross, op. cit., p. 51; claim forms pages 197-207.

16 United Nations. 1948, Universal Declaration of Human Rights, 10 December. Available at www.un.org/en/universal-declaration-human-rights/index.html.

17 The day after the Declaration was adopted, the General Assembly passed a resolution on Palestine, which in paragraph 11 said "that compensation should be paid for the property of those [refugees] choosing not to return and for loss of or damage to property which, under principles of international law or in equity, should be made good by the Governments or authorities responsible." A/ RES/194 (III), 11 December 1948. Available at https:/unispal.un.org/DPA/DPR/ unispal.nsf/0/C758572B78D1CD0085256BCF0077E51A.

18 Glendon, Mary Ann. 2001, The World Made New: Eleanor Roosevelt and the Universal Declaration of Human Rights. New York: Random House, p. 195.

19 United Nations. 1966, International Covenant on Civil and Political Rights. Available at www.ohchr.org/EN/ProfessionalInterest/Pages/CCPR.aspx.

20 United Nations. 2015, United Nations Congresses on Crime Prevention and Criminal Justice 1955-2015: 60 Years of Achievement. Available at www. un.org/en/events/crimecongress2015/pdf/60_years_booklet_EN.pdf.

21 Declaration of Basic Principles of Justice for Victims of Crime and Abuse of Power, United Nations General Assembly, A/RES/40/34, 29 November 1985.

22 UN Doc. E/CN.4/Sub.2/1990/10 (26 July 1990).

23 United Nations General Assembly resolution 60/147. 2005, Basic Principles and Guidelines on the Right to a Remedy and Reparation for Victims of Gross 
Violations of International Human Rights Law and Serious Violations of International Humanitarian Law, 16 December. Available at http://legal.un.org/avl/ pdf/ha/ga_60-147/ga_60-147_ph_e.pdf.

24 Ibid., para 20.

25 Ibid., para 15.

26 In an influential 1997 report to the UN Commission on Human Rights on the question of impunity of perpetrators of human rights violations, the distinguished legal scholar Louis Joinet proposed five principles on the "preservation of and access to archives bearing witness to violations." Professor Diane Orentlicher updated the principles in 2005. The Administration of Justice and the Human Rights of Detainees: Question of the impunity of perpetrators of human rights violations (civil and political). Revised final report prepared by Mr. Joinet pursuant to Sub-Commission decision 1996/119, United Nations Commission on Human Rights, Sub-Commission on Prevention of Discrimination and Protection of Minorities, E/CN.4/Sub.2/1997/20/Rev.1, 1997-10-02; rev. by Diane Orentlicher, E/CN.4/2005/102 and E/CN.4/2005/102/Add.1, 8 February 2005. Available at https://documents-dds-ny.un.org/doc/UNDOC/GEN/G05/109/00/ PDF/G0510900.pdf? OpenElement.

27 Ibid., para. 24.

28 The International Criminal Court began operating in 2002, following the ratification of the Rome Statue of 1998 by 60 state parties.

29 UN Human Rights Committee (HRC). 2004, General Comment No. 31 [80], the Nature of the General Legal Obligation Imposed on States Parties to the Covenant, 26 May, CCPR/C/21/Rev.1/Add.13, para. 8. Available at www.refworld.org/docid/478b26ae2.html.

30 The European Court of Human Rights was established in 1953 and reformed in 1998, having been relatively quiet during the Cold War when Europe was divided. A state, group, or individual (who need not be a citizen of one of the state parties) can submit a complaint; however, the jurisdiction was limited to claims that a state violated the European Convention on Human Rights, excluding the possibility of claiming against a non-state actor. The African Court of Human Rights came into force in 2004; Asia does not yet have a similar court.

31 However, Article 10 specified, rather confusingly, "Every person has the right to be compensated in accordance with the law in the event he has been sentenced by a final judgment through a miscarriage of justice." This appeared to limit the scope of compensation to those improperly convicted. American Convention on Human Rights, 22 November 1969. Available at www.cidh.oas.org/Basicos/ English/Basic3.American\%20Convention.htm.

32 Inter-American Court of Human Rights, "Court History." Available at www. corteidh.or.cr/index.php/en/about-us/historia-de-la-corteidh.

33 The 20 states are Argentina, Barbados, Bolivia, Brazil, Chile, Colombia, Costa Rica, Dominican Republic, Ecuador, El Salvador, Guatemala, Haiti, Honduras, Mexico, Nicaragua, Panama, Paraguay, Peru, Suriname, and Uruguay. Previously, Trinidad and Tobago and Venezuela had both accepted the Court's jurisdiction, but withdrew from that jurisdiction when they denounced the American Convention, in 1998 and 2012, respectively. Ibid.

34 Velasquez Rodriquez, Inter-American Court of Human Rights, Judgment on Compensatory Damages, Judgment of July 21, 1989, Series C, No. 7, in Neil J. Kritz, ed. 1995, Transitional Justice: How Emerging Democracies Reckon with Former Regimes, Volume III Laws, Rulings, and Reports. Washington, DC: United States Institute of Peace, pp. 739-747. All citations from Kritz use the English translations therein provided.

35 De Greiff, op. cit. Argentina, pp. 702-731. All citations from de Greiff use the English translations therein provided.

36 Ibid. 
37 Ibid.

38 Argentina had issued National Decree 70/91 on the topic in January 1991, which was then codified by the November 1991 Law 24.043.

39 De Greiff, op. cit. Argentina, pp. 702-731.

40 Ibid.

41 Ibid.

42 De Greiff, op. cit., Brazil, pp. 760-763.

43 The Commission did not receive full cooperation from the military to provide access to their archives, leaving the burden of proof with the relatives of deceased victims. Further, where official archives that were available told one story, later proven to be false, "cases in which no documents supported the alternative version received no compensation." Ignacio Cano and Patricia Galvao Ferreira, "Reparations Program in Brazil," in: De Greiff, op. cit., Brazil, p. 119.

44 Lei No. 10.559/2002, de 22 de Novembro de 2002. Available at www.justica. gov.br/seus-direitos/anistia/.

45 The Commission received 75,000 petitions. Thanks to Vitor Fonseca for the references.

46 Kritz, op. cit., Chile, pp. 685-695.

47 As Cath Collins points out, "The pensions accruing to one and to the other situation were and are widely different, consisting of approximately US\$666 per month for Rettig [first commission] families and US\$217 for individuals named by Valech." Collins, Cath. 2016, "Truth-Justice-Reparations Interaction Effects in Transitional Justice Practice: The Case of the 'Valech Commission' in Chile," Journal of Latin American Studies, August, pp. 1-28, quotation fn. 65.

48 Kritz, op. cit, Albania, pp. 661-666.

49 Krtiz, op. cit., Bulgaria, pp. 672-684.

50 Kritz, op. cit., Russia, pp. 797-807.

51 The five elements were a Common Experience Payment (CEP) for all eligible former students of Indian Residential Schools; an Independent Assessment Process (IAP) for claims of sexual or serious physical abuse; measures to support healing such as the Indian Residential Schools Resolution Health Support Program and an endowment to the Aboriginal Healing Foundation; commemorative activities; and the establishment of a Truth and Reconciliation Commission. The IAP was also an individual claims process that used an evidentiary procedure separate from the CEP.

52 Public Law 100-383, 102 Stat. 903, “An act to implement recommendations of the Commission on Wartime Relocation and Internment of Civilians," 10 August 1988. Available at www.gpo.gov/fdsys/pkg/STATUTE-102/pdf/STATUTE-102-Pg903.pdf. The Act also made restitution to Aleut residents of the Pribilof Islands and the Aleutian Islands that were destroyed during World War II. In addition, to settle a civil lawsuit brought by four Japanese Latin Americans, the government also paid \$5,000 to 145 Japanese Latin Americans who were deported from their homes in Latin America during World War II and held in internment camps in the United States.

53 "Declarations of Eligibility by Persons Identified by the Office of Redress Administration and Requests for Documentation," 28 Code of Federal Regulations, Chapter 1, Part 74, Subpart E, Appendix A. Available at www.gpo.gov/fdsys/ pkg/CFR-2011-title28-vol2/xml/CFR-2011-title28-vol2-part74-appA.xml.

54 Compact of Free Association between the Government of the United States and the Government of the Republic of the Marshall Islands, Section 177 (b), 25 June 1983.

55 Nuclear Claims Tribunal. ca. 1989, "Regulations Governing Practice and Procedure," n.d. Copy in author's possession.

56 International Justice Monitor. 2017, "The Trial of German Katanga \& Mathier Ngudjolo Chui: Trust Fund Unveils Reparations Plan for Katanga Victims," 


\section{Trudy Huskamp Peterson}

5 September. Availableatwww.ijmonitor.org/2017/09/trust-fund-unveils-reparationsplan-for-katanga-victims/.

57 Writing in 2014, the World Bank and the World Health Organization said, "In the past 10 years, there has been an overall increase in global birth registration rates of children under five from 58 percent to 65 percent. However, more than 100 developing countries still do not have functioning systems that can support efficient registration of births and other life events like marriages and death." In 2015 they began a "Global Civil Registration and Vital Statistics Scaling Up Investment Plan," with a goal of having "universal civil registration of births, deaths, marriages, and other vital events, including reporting cause of death, and access to legal proof of registration for all individuals by 2030." Available at www.worldbank.org/en/topic/health/publication/ global-civil-registration-vital-statistics-scaling-up-investment.

58 Joya, Bahaar. 2017, "Where Is My Name? Afghan Women Fight for Their Own Identity," Thomson Reuters Foundation, 27 July. Available at http://news.trust. org/item/20170727230424-vl88t/.

59 International Committee of the Red Cross. 2015, "Chile: ICRC Stores DNA in Search for Missing Persons," 21 January. Available at www.icrc.org/en/document/chile-icrc-stores-dna-search-missing-persons; "ICRC Collects DNA to Identify Lebanon's Civil War Dead,” AFP, July 2016. Available at www.yahoo. com/news/icrc-collects-dna-identify-lebanons-civil-war-dead-173910965.html.

60 De Greiff, op. cit., Argentina National Decree 1.228/87, Article 1(b).

61 Pross, op. cit., pp. 197-207.

62 The New York Times published a long report on the enslavement and systematic rape of captive Yazidi women and girls by Islamic State fighters. The Islamic State "has developed a detailed bureaucracy of sex slavery, including sales contracts notarized by the ISIS-run Islamic courts." Women who managed to escape said that "their status as a slave [was] registered in a contract. When their owner would sell them to another buyer, a new contract would be drafted, like transferring a property deed." At least one woman was set free and given a "Certificate of Emancipation" signed by an Islamic State judge. Some of the captive Yazidi women "were bought by wholesalers, who photographed and gave them numbers to advertise them to potential buyers." Callimachi, Rukmini, "ISIS Enshrines a Theology of Rape," New York Times, 13 August. Available at www.nytimes.com/2015/08/14/world/middleeast/isis-enshrines-a-theology-ofrape.html?mkt_tok=3RkMMJWWfF9wsRonv6vKdO\%2FhmjTEU5z17u0kUK Cg38431UFwdcjKPmjr1YIHRMFqI\%2BSLDwEYGJlv6SgFSLHMMa12z7gL $\mathrm{XxI} \% 3 \mathrm{D} \&$ \& $=0$.

63 Indigenous and Northern Affairs Canada, Indian Residential Schools, Common Experience Payments. Available at www.aadnc-aandc.gc.ca/eng/110010001559 4/1100100015595.

64 Roberto, Claude. Indian Residential Schools Truth and Reconciliation Commission of Canada: Accountability, Transparency and Access to Information. Available at www.ica.org/en/claude-roberto.

65 Agreement between the United States of America and France, Claims and Dispute Resolution, Treaties and Other International Acts Series 15-1101, 8 December 2014. Available at www.state.gov/documents/organization/251005.pdf.

66 "Netherlands Found Partially Liable for Srebrenica Deaths," BIRN, 27 June 2017. Available at www.balkaninsight.com/en/article/srebrenica-netherlands-peacekeepers-verdict-06-27-2017?utm_source=Balkan+Transitional+Justice+Daily+News letter+-+NEW\&utm_campaign=186f3c69a3-RSS_EMAIL_CAMPAIGN\&utm_ medium=email\&utm_term=0_a1d9e93e97-186f3c69a3-319755321. 
Africa 
$\because$ Taylor \& Francis Taylor \& Francis Group http://taylorandfrancis.com 


\section{A long walk to justice \\ Archives and the truth and reconciliation process in South Africa}

\section{Graham Dominy}

"Without memory, there is no healing. Without forgiveness, there is no future."

(Archbishop Desmond Tutu; Chair of the Truth and Reconciliation Commission)

\section{Introduction}

It has been more than 20 years since Archbishop Desmond Tutu handed President Nelson Mandela the main report of the South African Truth and Reconciliation Commission (TRC). The TRC had been appointed in 1995 to investigate human rights abuses during the apartheid era and it exposed the horrors of systemic torture, political oppression and economic deprivation. According to Justice Minister Dullah Omar, the TRC was a necessary exercise to enable South Africans to come to terms with their past on a morally accepted basis and to advance the cause of reconciliation.

The TRC will act as the prism through which to examine the struggle for human rights in South Africa at the dawn of democracy and its dual role of record-seeking and recordkeeping played in the process will be discussed. The National Archives of South Africa and its predecessor, the State Archives Service, had two fundamental roles in the process: to assist with the TRC's search for documentation and to archive the records of the TRC, once it had completed its deliberations. The TRC process rested on both the willingness of ordinary people to testify to their experiences and the availability of records. In addition, there is the complex question of access to the TRC records that also requires attention.

\section{Background}

To properly understand the context of the TRC, it is necessary to sketch the history of the deprivation of human rights in South Africa. The system of enforced segregation known as apartheid grew out of centuries of colonialism. Economic development was characterised by the exploitation of the African population as labourers on white-owned farms, in mines and 


\section{Graham Dominy}

in industry. It was also characterised by the loss of land by black South Africans to white settlement and the curtailment of civil liberties. By the 1970 s, $13 \%$ of the population controlled $87 \%$ of the land. Apartheid can be described as a vast social engineering experiment aimed at the complete separation of the races, inspired by the so-called Architect of Apartheid, Prime Minister Hendrik Verwoerd (Prime Minister 1958-1966).

In the 19th century, two British colonies controlled the South African coastline and two Boer republics controlled the interior. Traditional African societies were conquered, or otherwise absorbed into the colonial system. After a savage war between 1899 and 1902, the two former Boer republics and the two British colonies united as the Union of South Africa in 1910. This new British dominion reserved the franchise almost exclusively for whites, with the Coloureds (mixed race community) in the Cape Province retaining their colonial era voting rights. The African National Congress (ANC) was formed in 1912 to protest this situation. When the Afrikaner National Party took power in 1948, it set about rigidly imposing social and political segregation through legislation, the system described as apartheid. The first target was the voting rights of Coloureds and, after a prolonged constitutional struggle, they were deprived of their franchise in 1956.

The struggle against apartheid was long and multifaceted: military, political, economic, educational and religious. The record of human rights violations is equally varied. The first major campaign was against the carrying of identity documents, the so-called dompas (English translation: stupid pass). This prompted the adoption of the Freedom Charter in June 1955, which articulated a list of demands setting out a vision of a new, democratic South Africa, a vision that took until 1994 to realise.

On 21 March 1960, the Sharpeville Massacre took place when 69 unarmed protesters were killed by the police during an anti-pass law march. A State of Emergency was declared, and the era of peaceful protest ended abruptly. The ANC launched its campaign of armed resistance the following year and its leadership established a clandestine headquarters at Liliesleaf Farm in Rivonia, north of Johannesburg. Its location was betrayed to the police and a raid caught the main ANC leaders unawares, except for Nelson Mandela, who was already in jail for minor offences, but documents found during the raid implicated him in more serious activities.

The resulting court case, known as the Rivonia Trial, received international publicity and the apartheid government was widely condemned. The publicity may have influenced the judge in his sentencing, because he imposed life sentences rather than the death penalty. Then began the long years on Robben Island for Mandela and his comrades. By 1964, the apartheid regime had crushed all overt resistance and remained virtually all powerful until the youths of Soweto rose in anger in 1976. From 1976 until the release of Nelson Mandela in 1990, South Africa writhed in increasing turmoil. 
During the leadership of PW Botha (Prime Minister 1978-1984; President 1984-1989), security regulations were tightened further and Botha declared that South Africa was under a "total onslaught" from liberation forces supported not only by communist regimes and liberated African states but also by the majority of members of the United Nations. The response of Botha and his colleagues was to devise a "total strategy". This was given effect by the construction of a parallel state structure responsible to the State Security Council, rather than to the civilian Cabinet or parliament. The system was administered by the Security Secretariat, comprising the top brass in the military, the police and the intelligence services, who were collectively known as the "securocrats".

Internal and external pressure had rendered apartheid unsustainable by the late 1980s, and in 1990 Botha's successor, F.W. de Klerk (State President 19891994), released Mandela, unbanned the ANC and other liberation movements and opened negotiations with them. Apartheid was in its death throes.

The governmental system, from colonial to apartheid times, with its increasing obsession with racist and separatist ideologies and their regulation, generated records reflecting government control from the management of black labour, to the classification of people by race, to the operations of the security forces in oppressing the general populace. The obsession with racial separation at all levels meant that all government organs, from the headquarters in the Union Buildings to local town halls and police stations, generated vast quantities of records reflecting the complex and confusing hierarchies of government. This was exacerbated by the addition of the layer of securocratic bureaucracy imposed by the Botha Government as it struggled against apartheid's increasing isolation.

\section{Destroying the evidence}

In July 1993, as the country edged painfully, but inexorably towards democracy, all government departments were instructed by the Security Secretariat to destroy all classified records received by them from other sources (with the exception of unaudited financial records). Anecdotal evidence exists that truckloads of records were dumped in the furnaces of the state-owned Iscor steel works. However, only the State Archives was empowered to authorise the disposal of records by destruction or other means, so the instruction could be and was legally challenged.

The State Archives was alerted to the existence of some surviving security records by a regional government office that had not received the circular and contacted the National Archives to request guidance. An alert archivist ordered the immediate transfer of the records to safety in the archives and these later provided crucial evidence for the TRC.

After the first non-racial democratic elections, the Government of National Unity took office with Mandela as president and F.W. de Klerk as one of the two deputy presidents. Addressing the legacy of past oppression was one of 


\section{Graham Dominy}

the new government's urgent priorities. The functionaries and politicians of the apartheid regime wanted the past forgotten and for a blanket amnesty to be promulgated. On the other hand, many radicals preferred a Nuremberg Trials scenario - show trials of former oppressors that would satisfy their desires for vengeance. ${ }^{1}$

The TRC, therefore, was inevitably the result of political compromises. It chose to focus on the surviving records of the security system, despite the systematic destruction of a huge body of state records and documentation as part of an attempt to remove incriminating evidence and thereby sanitise the history of oppressive rule. The reason for this was the TRC's very tight legislated time frame and its limited resources, given the enormity of the competing demands on a denuded fiscus. The departing apartheid regime had completely stripped the National Treasury of its funds and assets.

According to Marius Oosthuizen, "Simply put, understanding apartheid requires understanding how it worked." ${ }^{2} \mathrm{He}$ uses the example of how state direction of the vast Sasol synthetic oil-from-coal plant and the extensive Iscor steel works in the Vaal Triangle buffered the apartheid regime from many of the effects of international sanctions. He contrasts the access of white workers to cheap company housing, free education and other privileges with the black work force of migrant labourers living in single sex hostels, without their families, with minimal leisure activities and few educational opportunities. This played its part in "creating a generational and systemic tragedy, 100 years in the making." It is no surprise that the townships around the Vaal Triangle, such as Sharpville, were at the epicentre of the anti-apartheid uprisings.

A more focused example is that of the National Prosecuting Authority's Missing Persons Task Team. Established in 2005, the Task Team's purpose was to locate the remains of missing persons identified at the TRC hearings, by 2015 it had located 98 bodies. $^{3}$ The team was heavily dependent on records and interviews for its clues; they combed through TRC records, court transcripts, police dockets, mortuary books and cemetery records.

These two examples, one economic and one harrowing, illustrate the imprint of state oppression on the South African archival record: it is not only the records of the organs and actors of government but also those of the state-owned enterprises, private enterprise and the mundane series of local records which need to be interrogated in order to understand the impact of apartheid on human rights: court records, police records, local records (births, death and marriages), diplomatic, political, military and para-military records.

\section{The TRC, the National Archives and sensitive records}

The example of South Africa's TRC and the role of the National Archives of South Africa (successor, in 1996, to the apartheid "State Archives") will be used to illustrate some of the dangers that human rights-related 
records are subjected to during times of major political transition. It was well understood by archivists and historians that a careful analysis of the archival record would lay bare the chief features of the apartheid system and contextualise the uneven development, social contradictions and anomalies in South Africa's first decade of democracy. In 1994, this was more than just an intellectual need, it was a political imperative, born of the processes of conflict and negotiation that led to the establishment of the democratic order. Those who had been oppressed, who had lost loved ones and whose lives and livelihoods had been destroyed, thirsted to know the reasons why.

The establishment of a mechanism to address the needs of the oppressed, without provoking the former oppressors into revolt and racial civil war, was essential. Therefore, the establishment of the TRC was one of the most important actions that the newly elected democratic parliament took in its first year in office. The newly created body was tasked with investigating the atrocities of the past; exposing the evils committed in apartheid's name and in the name of those struggling to overthrow the system; giving amnesty to perpetrators who fully disclosed their misdeeds (if such deeds had a political purpose) and building a database of those victims who required compensation or restitution in some way or another. The aim of the TRC was summed up in its name: to discover the truth and to seek to achieve reconciliation.

There were three aspects to the archival work of the TRC that are of relevance:

In order to fulfil its mandate to discover the truth about the apartheid past, the TRC searched for, and sometimes seized, many of the records of those involved in the apartheid security apparatus. This required the intervention of archivists in support of other investigators.

The TRC generated a vast amount of documentation during its lifespan in all modern media: paper-based; audio; visual; audiovisual and electronic, all requiring archiving.

The TRC made a number of archives-related recommendations that required a response from the National Archives of South Africa and other agencies. These are discussed in the Archival Platform report, State of the Archives, by Jo-Anne Duggan. ${ }^{4}$

\section{The TRC's hunt for the archives of oppression}

The TRC was hampered in its efforts to obtain documentation about apartheid atrocities by a lack of resources, staff, time and, more importantly, obstructionism from within the former security apparatus and other sections in the apartheid bureaucracy. Above all, it was severely hampered in its efforts by the previously mentioned massive illegal destruction of records ordered in the months leading up to the first democratic elections on 27 April 1994. 
A former TRC official made the observation to this writer that perhaps the only offence that could conclusively be pinned on former State President F.W. de Klerk was ordering the destruction of State documents without following the requirements of the old State Archives Act (which provided for a modest fine for the illegal destruction of official records). A further observation is that the "whistleblower" on the destruction of security records was a member of the staff of the National Archives who went on to work with the TRC in its search for records.

The five-volume report of the TRC describes at some length the steps taken to search for records documenting the atrocities of apartheid: in situ inspections, correspondence with various agencies and, ultimately, the use of legal warrants to seize documents. The documentation that was located included:

Surviving copies of records of the State Security Council and the parallel government of "securocrats" that swung the resources of the State behind the so-called total strategy

Files on individuals from the Department of Justice (DOJ) section which authorised detention without trial and intrusive observation and eavesdropping

Security Police files

Military documentation

Secret intelligence files from the apartheid era National Intelligence Service and its Orwellian-named predecessor, the Bureau of State Security (BOSS)

The National Archives seconded officials, including Verne Harris, to assist with this process. ${ }^{5}$ Harris subsequently exercised a considerable influence on the archives-related recommendations of the TRC. International experts, such as Trudy Huskamp Peterson, also advised the TRC on archival matters. Harris left the National Archives in 2001 to head the South African History Archive (SAHA), a non-governmental organization based at the University of the Witwatersrand (modelled on the National Security Archive in Washington, DC), which has been running a Freedom of Information project, centering on the TRC files and other documentation from the apartheid era. Various writers and political activists have subsequently claimed that much evidence was hidden from the TRC and only came to light later as a result of Promotion of Access to Information Act access applications submitted to the military, among others. The National Archives also managed to secure the transfer of files relating to political prisoners that were not part of the TRC archives, but were prison administrative records.

\section{Archiving TRC records}

The TRC closed its offices in Cape Town in 2001 and its records were transferred by overnight train to Pretoria, an exercise undertaken by the 
police and military. The National Archives made special storage and security arrangements for the TRC records. The TRC's legislation had been amended to specify that the DOJ became its successor-in-title and this department assumed responsibility for its assets and liabilities, including its "intellectual property." Intellectual property was taken to include the TRC's records, although the TRC had itself recommended that these be taken to the National Archives. Nevertheless, on the recommendation of the security and intelligence services, the TRC records were placed in the National Archives. Access was a different matter given the role of the DOJ. Public access was therefore managed under difficult circumstances of dual control, inadequate and conflicting legislation, complicated bureaucratic requirements and very public acrimonious criticism by NGOs and academics. ${ }^{6}$ Notwithstanding these difficulties, the National Archives was required to play its integral and important part in the exercise of peoples' human rights.

The march of events, and the continuing processes of democratising South Africa, has overtaken some of the TRC's archival recommendations. One of the most important events was the passing into law of the constitutionally mandated Promotion of Access to Information Act (PAIA) in the year 2000. This must be seen as a giant leap forward, because it was competing with the more pressing human needs of access to housing, health, education, water and power.

In 2001, the TRC finalised its official work as its legal, time-bound, mandate had elapsed, and differences of emphasis appeared between the various agencies with roles to play in the follow-up work.

It is perhaps appropriate to list the other steps that have been taken by the National Archives to archive the TRC records and manage the accessibility to the records of human rights researchers and victims' families:

A special section was established at the National Archives to manage the TRC records and the other security-related and sensitive records that were transferred to the National Archives in terms of the TRC's recommendations.

Two former TRC officials were appointed as archivists to assist the National Archives with the processing and management of the records and to manage work with PAIA requests.

Two strong rooms were equipped with additional security measures for storage of TRC and other sensitive records.

A project was established to archive the electronic records of the TRC but languishes due to lack of funding.

All TRC Commissioners were informed of their obligations to transfer official records to the National Archives, but there was little response.

A joint committee was set up with the DOJ and with the National Intelligence Agency (NIA) to implement access requests to the TRC records in terms of PAIA. 


\section{Graham Dominy}

More resources and trained personnel are required to complete the task. The budget for the National Archives does not match its legally mandated responsibilities, let alone allow it to fully carry out the idealistic recommendations of the TRC.

\section{Accessing sensitive records}

The South African National Archives Act of 1996 is in serious need of a complete overhaul to be fully compatible with the Constitution and laws on access to information, protection of privacy and personal data that flow from the constitution. One area that needs legal clarification is aligning the clear instruction of the archives law that records are open after 20 years, with the conflicting requirements of the other legislation.

The National Archives broadly applies PAIA as its primary guideline. The constitutionally mandated PAIA gives expression to a fundamental human right and, therefore, would supercede the National Archives Act should a legal, or interpretative, conflict arise. Arranging access to TRC records can be a problem because of the previously mentioned system of dual control with the Department of Justice. However, in order to reduce delays, the National Archives allows open access to all TRC records that relate to public hearings and non-confidential discussions.

Effectively, this means that only a minority of TRC access requests have to go through the dual committee system. Access to other sensitive records is dealt with in terms of PAIA principles. For example, a person may have access to their own records as a political prisoner, but access would not be granted to a third party unless the ex-prisoner gave his or her permission. Generally, co-operation between the National Archives, the military and the police on access to sensitive records is courteous, professional and helpful. This is essential in sustaining the role of the archives as an institution trusted by both the public and the organs of state.

One issue that is often not considered by politicians debating secrecy or privacy legislation is how long should the protections last? PAIA implies that restrictions are lifted after 20 years, which accords with the National Archives Act, but, as yet there has been no test case.

The "Right to Know" is one of the most broad and fundamental of human rights. In many ways it frames the relationship between the citizen and the State. In the South African Constitution, this is encapsulated in the Bill of Rights as the right to "Freedom of Expression," which includes:

a Freedom of the press and other media

b Freedom to receive or impart information or ideas

c Freedom of artistic creativity

d Academic freedom and freedom of scientific research 
The Constitution also provides a right of “Access to Information," which stipulates that "Everyone" has the right of access to:

a Any information held by the State

b Any information that is held by another person that is required for the exercise or protection of any rights

These rights are implemented through legislation, but they are not absolute in all respects. Consequently, administering and interpreting them in the archival context requires a delicate balancing act. The ICA's "Principles of Access to Archives" give professional operational guidelines which have been of great value to the South African National Archives. The United Nations Principles to Combat Impunity, drafted by Louis Joinet in 1997 and updated by Diane Orentlicher in 2005, emphasises that the Right to Know includes the duty of States to preserve memory. ${ }^{7}$ The transitional justice imperative of "memorialisation" (flowing from the four pillars of the Joinet Principles) compared with the pure archival imperative to collect, appraise, preserve and make accessible provides a useful illustration of the tensions between the recommendations of the TRC regarding the management of the TRC Archive and the legal requirements of the Archives Act and PAIA when dealing with requests for access. Without supporting the critical services that are provided by the National Archives, governments cannot support their citizens' "Right to Remember."

Duggan is, in her aforementioned report, highly critical of both the DOJ and the National Archives for their handling of the TRC records and applications for access to the records. The report also alleges that both entities used PAIA to block access to the TRC records. However, because civil society organizations repeatedly made their requests for access to records of confidential TRC hearings (the so-called Section 29 hearings), in terms of PAIA, this obligated the DOJ and the National Archives to consider the access requests strictly in terms of the requirements and the exemptions set out in PAIA.

As the "mere" custodian of the TRC records, the National Archives could not do much more than make suggestions regarding the implementation of access to the records. When PAIA requests for access to confidential TRC and other security records were received, the National Archivist was obliged to consult with the office of origin and give serious consideration to their views, regardless of personal and professional opinions. However, in 2010, the sensitive records section at the National Archives was instructed to give unfettered access to all TRC records, other than the originally confidential Section 29 hearings (which would still have to be accessed via the DOJ). This was to avoid following the cumbersome PAIA procedures. 


\section{Graham Dominy}

\section{Conclusion}

The long walk to justice in relation to the archiving and access to the TRC records is not complete, but a great distance has been covered. The National Archives has secured the records of the TRC, although it has not secured the funding to fulfil all the optimistic wishes outlined in the TRC report. A stable access regime has been developed and as 20 years have now passed since the final report was submitted, the National Archives has, in terms of its own legislation, a strong legal case to become the sole authority responsible for the access regime.

This development has come at an opportune time politically as the government of President Cyril Ramaphosa is committed to restoring the rule of law, so the inertia and impediments of the past nine years are disappearing. The new spirit of energy abroad in South Africa should be harnessed to resolve the outstanding issues relating to the TRC records. Let us hope that this will mean that future generations will study the TRC records for inspiration rather than out of necessity for searching for clues as to the fate of missing loved ones.

\section{Notes}

1 Report of the Truth and Reconciliation Commission of South Africa, vol. 1, p. 5, para 20-21. Available at www.sahistory.org.za/sites/default/files/volume_1_1.pdf.

2 Oosthuizen, M. 2019, "How South Africa Can Do Better at Reversing Apartheid's Legacies," The Conversation, 16 May. Available at https://theconversation.com/ how-south-africa-can-do-better-at-reversing-apartheids-legacies-116600?.

3 Van Der Leun, J. 2015, "The Odd Couple: Why an Apartheid Activist Joined Forces with a Murderer," The Guardian, 6 June. Available at www.theguardian. com/global/2015/jun/06/odd-couple-apartheid-activist-madeleine-fullard-convicted-policeman-eugene-de-kock.

4 Duggan, J., comp. 2015, State of the Archives: An Analysis of South Africa's National Archival System, 2014. The Archival Platform, Cape Town. Available at http://pmg-assets.s3-website-eu-west-1.amazonaws.com/150901archives.pdf.

5 Verne Harris: Archivist; Director of Archive \& Dialogue - Nelson Mandela Foundation; Hon. Research fellow UCT: seconded to the TRC; worked for South African History Archives; Deputy Director National Archives South Africa; widely published writer on archival matters with several awards to his credit.

6 This is reflected in the paragraphs of the TRC report quoted in note 1.

7 Available at https://documents-dds-ny.un.org/doc/UNDOC/GEN/G05/109/00/ PDF/G0510900.pdf?OpenElement.

\section{Bibliography}

Allan, K., ed. 2009, Paper Wars: Access to Information in South Africa. Johannesburg: Wits University Press.

Chipkin, I., and Meny-Gibert, S. 2012, "Why the Past Matters: Studying Public Administration in South Africa," Journal of Public Administration, vol. 47, no. 1, pp. 102-112. 
Constitution of the Republic of South Africa. 1996, Act No. 108 of 1996. Pretoria: Government Printer.

Dominy, G. 2005, "We Must Remember Our Past so That We Do Not Repeat It: Archiving and Accessing the Records of South Africa's Truth and Reconciliation Commission," Comma, International Journal on Archives, vol. 1, pp. 1-7.

_ 2013, "Overcoming the Apartheid Legacy: The Special Case of the Freedom Charter," Archival Science: International Journal on Recorded Information, vol. 13, pp. 195-205.

Duggan, J., comp. 2015, State of the Archives: An Analysis of South Africa's National Archival System, 2014. Cape Town: The Archival Platform.

Greenberg, M. C., Barton, J. H., and McGuiness, M. E., eds. 2000, Words Over War: Mediation and Arbitration to Prevent Deadly Conflict. New York: Carnegie Corporation, Rowman \& Littlefield Publishers.

Harris, V. 2007, Archives and Justice: A South African Perspective. Chicago: Society of American Archivists.

Lemieux, V. L., and Trapnell, S. E. 2016, Public Access to Information for Development: A Guide to the Effective Implementation of Right to Information Laws. Directions in Development Series. Washington, DC: World Bank. Doi:10.1596/978-1-4648-0879-1; license: Creative Commons Attribution CC BY 3.0IG0), accessed 7 January 2017.

Oosthuizen, M. 2019, "How South Africa Can Do Better at Reversing Apartheid's Legacies," The Conversation, 16 May. Available at https://theconversation.com/ how-south-africa-can-do-better-at-reversing-apartheids-legacies-116600?.

Rousseau, N., and Fullard, M. 2009, "Accounting and Reconciling in the Balance Sheet of the South African Truth and Reconciliation Commission," Journal of Multicultural Discourses, vol. 4, pp. 123-135.

SAHRC: South African Human Rights Commission. 2012, PAIA Annual Report 2011/12. Johannesburg: SAHRC.

Thomas, Kylie. 2019, “Ahmed Timol: The Quest for Justice for People Murdered in Apartheid's Jails," The Conservation, 14 May. Available at https://theconversation. com/ahmed-timol-the-quest-for-justice-for-people-murdered-in-apartheids-jails.

- 1998-2002, Truth and Reconciliation Commission Report, vols. 1-7, distribution. Cape Town: Juta \& Co Ltd.

Tutu, Desmond, and Allen, John, ed. 1994, The Rainbow People of God: The Making of a Peaceful Revolution. New York: Doubleday.

- Tutu and His Role in the Truth \& Reconciliation Commission, South African History Online: Towards a People's History. Available at www.sahistory.org. za/article/tutu-and-his-role-truth-reconciliation-commission.

Van der Leun, J. 2015, “The Odd Couple: Why an Apartheid Activist Joined Forces with a Murderer," The Guardian, 6 June. Available at www.theguardian.com/ global/2015/jun/06/odd-couple-apartheid-activist-madeleine-fullard-convictedpoliceman-eugene-de-kock. 


\title{
3 Tunisia's Truth and Dignity Commission
}

\author{
Archives in the pursuit of truth
}

Adel Maïzi

On 14 January 2011, after weeks of civil unrest, Tunisian President Zine El-Abidine Ben Ali ${ }^{1}$ bowed to protester pressure and fled the country. His departure marked the end of a dictatorial regime known for its control of the judicial system and the media, and its widespread abuse of public and individual freedoms.

Since the 2011 revolution, generally labelled non-violent, Tunisia has embarked on a process of democratisation and of coming to terms with its past. Transition processes gradually took shape between March and October 2011, spearheaded by the Higher Authority for Realisation of the Objectives of the Revolution, Political Reform and Democratic Transition. The National Constituent Assembly was elected in October 2011. This, in turn, elected Moncef Marzouki as the new President of the Republic.

Two years later, on 24 December 2013, the Assembly voted an organic law instituting transitional justice. In this law, provision is made for a series of judicial and non-judicial measures for discovering the truth about the human rights violations perpetrated in the country in the past, prosecuting the alleged perpetrators, compensating and rehabilitating the victims, while taking steps to "preserve and document collective memory" and ward against repetition of such events. The ultimate goals of all these arrangements is that of national reconciliation. ${ }^{2}$

The law also makes provision for the creation of an independent authority, the Truth and Dignity Commission, to be responsible for establishing the truth about the human rights violations that occurred under Ben Ali and his predecessor, Habib Bourguiba, in other words, since Tunisia first became independent. ${ }^{3}$

Four and a half years later, on 26 March 2019, the IVD published its final report. ${ }^{4}$ Archives were fundamental to the Commission and a major focus was at all stages of its work.

\section{Truth and Dignity Commission's roles and powers}

Articles $16-70$ of the law on transitional justice relate specifically to the IVD. The law tasked the IVD with ascertaining the truth about the 
violations perpetrated between 1 July $1955^{5}$ and 31 December 2013, when the law came into force. It was also required to set up a victim rehabilitation fund. Its mandate was to last four years, renewable for one further year.

The IVD had no legal empowerment. Its role was to record claims, register victims, conduct investigations and prepare the ground for legal proceedings. It was required to hand over its files on the most serious cases to the justice system: torture, rape, enforced disappearance, arbitrary execution, financial crime and embezzlement. The law made it clear that accountability lay with the judicial authorities, which were responsible for prosecuting the alleged offenders. Article 8 provided for the creation of special chambers within a number of Tunisian courts.

The legislator took account of experience in other countries which had lived through periods of repression and highlighted the importance of the documentary evidence of the violations. Article 1 of the law lays out one of its objectives as "preserving and archiving collective memory" and Article 5 states that

The preservation of national memory shall be a right guaranteed to all successive generations of ... Tunisians, and an obligation on the state and all the institutions answerable or accountable to it, so that lessons may be learned and victims commemorated.

Article 39 describes the IVD's role as being to "collect data, identify, list, classify, confirm and record violations with the aim of building a database and creating a single register of victims of violations."

Article 40 gave the IVD considerable powers to enable it to fulfil its role:

- Access to public and private records, regardless of any existing legislation to the contrary.

- The freedom to oblige the administrative and judicial authorities, public bodies and all individuals or legal entities to communicate documents and information in their possession.

- The right to go on fact-finding missions in public or private locations, conduct official searches and seize documents etc. in relation to violations under investigation. The Commission therefore had the same rights and powers as the police.

- Access to cases pending before the courts and to verdicts pronounced and rulings issued.

- The power to request information from official bodies in other countries and foreign non-governmental organizations, and to collect all requisite information from victims, witnesses, government officials and other parties, in other countries

- The ability to make use of any measures or methods likely to be of assistance in uncovering the truth. 


\section{Adel Maïzi}

Article 55 gave the president of the IVD the authority

when s/he discovers documents which s/he fears may be destroyed or in the presence of serious evidence of committed violations falling within the Commission's remit, allow necessary precautionary measures to preserve these documents and evidence and to prevent the perpetrators of these violations from replacing, disposing of, transferring or destroying the funds and properties subject of the crime.

Consequently, the IVD had unlimited powers to access all types of public and private records, archives, information and data, both inside and outside the country.

\section{Collection policy for records relevant to IVD's work}

Collecting records relating to human rights violations in Tunisia was of course one of the IVD's key responsibilities. Rather than physically collecting the records, the Commission obtained copies of documents from public and private archives that could be used as proof of these violations.

There were a large number of public archives with the potential to be of interest to the IVD. They were mainly located within government agencies (the President's office, Ministries and the Parliament), local authorities and similar organizations. Records kept in private organizations were also of potential interest to the Commission. Examples include the archives of the Democratic Constitutional Rally (RCD), the ruling party disbanded after the fall of Ben Ali, the Tunisian General Labour Union (UGTT), opposition political parties from the pre-revolutionary era, civil society organizations such as associations, and private individuals, families, political figures, the press, etc. The IVD also looked at archives and information to be found in foreign public institutions and non-governmental organizations where these were directly connected with the history of the violations in Tunisia.

As the Commission obviously could not collect and analyse all the archives belonging to these organizations, it developed a specific procedure for identifying and locating those of relevance for its work, namely that of mapping.

The IVD used the very wide interpretation of the term "archives" established by the Tunisian law of 2 August 1988, which defines them as "all documents, regardless of date, format and medium (physical or virtual), produced or received by any individuals or entities, and by any public or private departments or organisations in the course of their business." ${ }^{6}$ The IVD took an interest in archives wherever they were located, in the country and elsewhere, using the authority granted to it by the law on transitional justice.

Tunisia has a long-standing archiving tradition together with the corresponding comprehensive legislation requiring administrations to manage documents from their creation until such time as they can be eliminated in 
accordance with preset disposal schedules. ${ }^{7}$ The word "archives" is commonly used in its more limited sense to mean documents that have been archived and no longer have any current value. But in the case of transitional justice, all archives can still be used to legal, financial and jurisdictional effect. They can therefore be considered to have current value, even when previously classed as historical archives.

The Commission began by taking stock of and mapping existing archives, to locate those likely to contain details of violations, police archives in particular, because pre-revolutionary Tunisia was essentially a police state. It visited a number of ministries such as those of the Interior, Justice, Health and Finance to consult their archives, as well as the Directorate General for Archives, to obtain copies of records that had already been transferred to the Tunisian National Archives.

These procedures were required for two reasons. Firstly, because documents relating to an institution's activities can contain evidence of major human rights abuses perpetrated by agencies of the State, or by groups or individuals acting on behalf of the State or under its protection, even if they were neither entitled nor empowered to this effect. Secondly, because it is vital to keep a trace of violations.

It was therefore necessary to conserve not only the historical archives but also more recent records that might otherwise have been destroyed under the disposal schedules of the authorities concerned. This was even more vital in that, after the revolution, the National Archives had taken no special measures to protect records of potential use for transitional justice purposes. As no moratorium had been imposed on disposals, the authorities continued to destroy archives according to the pre-established schedules.

For the mapping process, the archivists recruited by the IVD were primed about the specificities of archives in transition situations, questionnaires and templates were developed and tested with two international non-governmental organizations and a detailed programme of visits was finalised. The IVD drew up an inventory of the archives of various public and private sector institutions across Tunisia. The archives of 213 public and private sector institutions were identified, in particular those of the Ministry of Defence, the Ministry of the Interior, the police, prisons, NGOs, trade unions, state television and the Tunisian Red Crescent. The institutions most relevant to the Commission's work were given priority status. In addition to archives in Tunisia, those held by international organizations and archives in France of potential interest to the IVD were also mapped.

The team tasked with mapping undertook numerous assignments all over Tunisia. After a trial period, it began the process of data input, while the collection of information was still in progress. Consequently, information was fed in stages into the research interface with the archives department making this interface available to the other IVD agencies. The IVD's various research teams were able to use the documents flagged up during mapping for their investigations. These covered a vast area and were of great 
assistance to the IVD. They will also be useful for future transitional justice operations in Tunisia. It was important to ensure that the results of this work were made available to IVD Board members for use in the various committees and to avoid all risk of duplication.

The Commission had to deal with documents of all sorts and sizes that needed to be processed before they could be used to identify the perpetrators of violations and their victims: hard and soft copy archives, data, audiovisual archives, public and private records, objects and DNA tests. The IVD organised its work to guarantee the authenticity and reliability of the records and ensure data security. Venues were selected for receiving those who wanted to lodge claims, and a very elaborate system of online and paper registrations was created. More than 62,000 complaints were filed through this system. These were immediately sealed and sent for digitisation. They were then entered into a database, so that the IVD commissioners and analysts could work exclusively from digital files. The hard copies were transferred to a state-of-the-art archiving facility designed to industry security standards. The IVD provided suitable organisational arrangements, by creating a document and archive management department, and recruiting more than 40 record, archive and information managers who worked closely with the IT department.

Besides digitising all the documents produced and received by the Commission, the electronic archiving system also had to manage born-digital documents. Thought was given to how these documents would be archived long term, to ensure they would remain intelligible, as well as to guarantee their authenticity, integrity and accessibility. A specific application, ArchIVD, was developed, in compliance to international standards, to facilitate any future migration of these documents and their long-term conservation. These technical issues were addressed during the IVD's mandate, which ended on 31 May 2019. Solutions will now have to be found by the institution inheriting responsibility for this material.

\section{Difficulties encountered}

IVD investigators had to overcome a number of difficulties which complicated their work. The hearings they organised opened a Pandora's box of accounts of cruelty, torture, rape and violence of all kinds. These hearings were followed by a third of the Tunisian population and gave rise to heated debate, making a mockery of the long-accepted official versions of the facts and exposing major violations. The IVD President, a long-standing human rights activist, was personally lambasted and became the target of controversy. The Commission's wide-ranging powers were condemned. It was criticised by politicians and media commentators, who tried to sabotage its work, accusing it of being biased and having its own political agenda. It was reproached for focusing solely on the RCD, the party that had been in power since 1956, and ignoring Ennahda, the Islamist party victorious in 
the 2011 elections. Some critics held that it had failed to search out those responsible for the terrorist attacks during the early post-uprising years. Others even went as far as to suggest that it might be preferable to drop the investigations and opt instead for closure.

The Commission accused some public sector agencies of hindering it in its work by failing to cooperate or even being obstructive. For example, it was unable to obtain access to the archives of the President's Office and the Ministry of the Interior, and its many requests for information about the identity of police officers involved in torture were stonewalled. The military courts also refused to provide the Commission with the legal documents about current cases. In addition, the President of the Republic had Parliament pass an "administrative reconciliation law" granting amnesty to civil servants involved in corruption cases. ${ }^{8}$ The IVD nevertheless succeeded in exposing a system of corruption and misappropriation of public funds involving civil servants from the Ben Ali era, courtesy of evidence from corrupt officials wishing to take advantage of the arbitration and reconciliation system provided for in the organic law on transitional justice. ${ }^{9}$ It was this lack of cooperation that prompted the Commission in February 2018 to ask for a year's extension on its mandate, as provided for in the law, but the Parliament refused its request. The Commission nonetheless continued its work, with the government's backing, but under challenging conditions.

\section{Results of IVD's work}

Despite these obstacles, the Commission was able to lay bare the extent of the crimes and human rights abuses committed in Tunisia and name those responsible. It published its final report on 26 March 2019, a seven-volume work of 2,344 pages. The report offers a detailed and well-documented analysis of the scale of the abuses perpetrated, in particular under Ben Ali, against Youssefists, ${ }^{10}$ the Beylical family, ${ }^{11}$ left-wing movements, Arab nationalists, Islamists, trade unionists and student movements. It also addresses the issue of corruption and misappropriation of public goods in sectors such as property, banking, public procurement, finance, the environment and natural resources and names executives involved in shady dealings and security excesses. The report is based on the large body of information amassed by the IVD: records identified during the mapping process, the Commission's investigations, testimonies given behind closed doors by 49,654 victims (totalling over 60,000 hours of recorded evidence), etc.

Of the report's 2,344 pages, 783 deal with the workings of the repressive system. Bourguiba and Ben Ali's regimes leveraged their repressive powers via two channels, both of which supported them unquestioningly: the judiciary and the prison system. The report provides a detailed description of the control exerted by politicians over the legal system: under Bourguiba there was a parallel justice system, with four special courts responsible for controlling civil liberties and severely sanctioning political opponents. 


\section{Adel Maïzi}

The police and secret services were answerable to Ben Ali and the regime made systematic use of arbitrary detention, torture and other inhumane forms of treatment. Demonstrations were violently repressed, and protestors arrested and jailed. Although the state security service was swiftly disbanded on 7 March 2011, less than two months after the fall of Ben Ali, the Ministry of the Interior refused to release its archives to the Commission. The Commission nevertheless managed to piece together the organization's structures, which had been a state secret to avoid accountability. It discovered the existence of a parallel police force, which delivered extrajudicial punishments with impunity. Intelligence agents had a slush fund to pay for their operations and enjoyed numerous privileges. While the Ministry of the Interior employed 45,000 civil servants, it had more than 120,000 informers.

During research to find those responsible for the assassination of Salah Ben Youssef ${ }^{12}$ in Frankfurt in 1961, the Commission cross-referenced several types of document: audio files, such as recordings of speeches by former President Bourguiba, where he talked about the national liberation movement, which it compared with printed materials, press articles and official documents. These confirmed its assumptions and enabled it to name those involved and prove the role played by state agencies in this assassination, classified by the IVD as a "state crime." In December 2018, the matter was referred to the criminal chamber specialising in transitional justice at the Tunis court of first instance. It resulted in the first transitional justice trial, 58 years after the elimination of Bourguiba's main opponent.

The Commission also pointed a finger at the systematic violations of prisoners' rights reported by 29,137 of the victims in their testimonies. Political prisoners were held in overcrowded prisons and at times had to share cells with the perpetrators of some of the most heinous crimes. During its on-site investigations across Tunisia, the team visited 20 of the 28 prisons selected during the mapping process. Unfortunately, all too frequently the prison buildings were run down and the prison records in dire condition. Most of the records that would have been relevant for the IVD's work had been burned or destroyed at the time of the revolution. In their search for key documents, the team also made carefully calculated visits to various courts and public authorities.

From the time Tunisia became independent in 1956, it was a one-party state. The Socialist Destourian Party (PSD), and the Democratic Constitutional Rally (RCD) that succeeded it in 1988 enjoyed unlimited powers. The many forms of collusion between the party and state institutions was one of the most important factors brought to light by the IVD's investigators and evidenced in a large number of documents. Party members were involved to differing degrees in human rights violations, in particular under Ben Ali.

One of the most significant discoveries unearthed during the mapping process was that of the archives of the departments in charge of monitoring the political activities of opponents to the regime and the movements 
of activists in the governates, ${ }^{13}$ and of prosecuting them when applicable. These departments produced reports for the Ministry of the Interior, which were many in number, although their size varied from one governate to another. The team did not expect to come across such collections of documents in the governates, but victims and political activists had managed to save them from being destroyed by the police during the general chaos of the revolution. These documents contained information of vital importance for the IVD, such as police reports and data on the treatment reserved for political opponents. Among other things, they showed how the surveillance system worked and made it possible to establish responsibilities.

\section{Recommendations}

In its final report, the IVD made hundreds of recommendations extending over all areas of its work. They spanned everything from the general (institutional reform, development model reform and governance of natural resources) to the specific (how history was to be taught, commemorative monuments, memorial sites, etc.), including the mechanisms underlying the administrative, legal, financial, institutional and educational systems, etc. The IVD recalled the fundamental principles that should govern the reforms, namely unqualified respect for human rights in the internationally recognised, comprehensive, complementary and interdependent acceptance of the term: real equality between men and women, respect for the constitution and international conventions, respect for the principles of governance and of decentralisation and local government.

It published 29,949 individual and collective decisions with regard to reparations for the victims of violations. ${ }^{14}$ Following nationwide consultations, it drew up plans for reparations, including financial compensation, psychological and physical rehabilitation, assistance in finding employment, etc. The 625 pages of Volume 6 of the report dealt exclusively with compensation and reparation: individual, collective (women, children, the disabled, minorities, etc.) or geographical.

Under the law on transitional justice, a fund was to be created for the Dignity and Rehabilitation of Dictatorship Victims. This is to compensate the victims of violations in several different ways. As yet, the fund remains an empty shell and doubts have been expressed with regard to the government's intentions over implementing the programme laid down by the law to enforce these recommendations, which may well meet with substantial political resistance. In the part of its report dealing with guaranteeing nonrepetition, the IVD urged the need to reform the laws and regulations that made malpractice and corruption possible. Its recommendations relate to institutional reform, the history curriculum, memory and the importance of conserving archives, including its own.

The report has yet to be uploaded to the Commission's website, even though under the terms of Article 67 of the law on transitional justice, it had 


\section{Adel Maïzi}

to be published in the Official Gazette. Article 70 of the law also required the Assembly to create a special parliamentary committee to implement the recommendations and proposals, but at the time of writing, no such committee had been set up (December 2019).

\section{Future of the archives and their use as part of a policy of remembrance}

At the end of its mandate, the IVD was in possession of an extensive and varied set of archives, including hard copy documents, databases, IT applications, software, websites, web pages, email addresses, books, thousands of photos, thousands of press kits, objects, audio and video recordings of the testimonies of 50,000 victims with a combined volume in excess of 80 terabytes. Given the personal nature of the data, this unique collection needs to be kept secure and physically intact, while also remaining accessible to researchers. It could form the basis for a centre for preserving national memory of human rights violations.

The law requires that, at the end of its work, the Commission should transfer all this material to the Tunisian National Archives or to a specific institution that may later be created to preserve national memory (Article 68). An institution of this type would have the advantage of keeping the memory of the abuses perpetrated alive. There are those who doubt the ability of the National Archives to accommodate all this material, on the grounds that they have neither the resources nor the skills required to manage audiovisual archives. In addition, all these archives and records must remain available to the magistrates presiding over the special criminal chambers replacing the IVD at the end of its mandate and tasked with handling investigations and prosecutions. The law on transitional justice may at times be in contradiction with the laws governing archives with regard to access to records containing so much sensitive personal data. Others also question whether the National Archives are sufficiently independent to manage these records, given their earlier unwillingness to cooperate with the IVD, taking the view that the National Archives need to be legally and administratively reformed and submitted to vetting processes. ${ }^{15}$

Public remembrance policies contribute to the recognition of all the victims and to stamping out the abuses of the past (exclusion, racism, corruption, impunity and violence) in order to create the conditions for a culture of democracy, justice and peace. When the IVD completed its work, its Committee for the Preservation of National Memory proposed a set of measures to ensure that the past should not be forgotten, cast off the shackles of dictatorship and protect future generations from any repetition of such violations. These included creating memorials, museums and memory tours in various parts of the country.

One proposal concerns the erection of a memorial to the 9 April Prison in Tunis. All the families of the opponents of the regime were held in this 
prison, which was completely demolished under Ben Ali in 2009. The site today is used as a car park, and there is nothing there to recall all the violence, torture, rape and hardship that went on there in the past. The Commission also considered the creation of a memorial site at the top of Mount Egri, near Tataouine in the south of the country, where IVD teams found human bones lying on the surface of the mountain slopes. ${ }^{16}$

All these archives could also be used by schools to teach children about their country's history. The Ministry of Education is legally empowered to include the subject of human rights and human rights violations in the curriculum. Creation of a memorial site could also be added to the agenda of the Ministry of Culture, for example via its department for promoting sources of memory and national identity. Numerous entities are answerable to this Ministry, such as the Agency for the Development of National Heritage and Cultural Promotion, the National Cultural Committee and the regional culture delegations in the 24 governates. For some, an institution responsible for memory could be grafted on to one of these existing bodies, while others favour the creation of a national centre for the preservation of memory drawing on experience gained when setting up these earlier bodies. Combining existing institutions with IVD archives would offer real added value to efforts to preserve this heritage and make it available to the public.

\section{Conclusion}

From work on centralising and digitising the documents collected and the links established between the database and the recorded archives (public and private hearings), it has been possible to produce records containing comprehensive evidence in support of the victims of violations and to identify the perpetrators. As one of the many techniques to bring the truth to light, archives played an innovative role, and were instrumental in changing government attitudes that were initially hostile to transitional justice.

Given its short-lived mandate, the large number of documents submitted for its attention and the complexity of its tasks, the IVD was only able to examine part of the archives collected and the presidential archives. This did not prevent it from uncovering the truth about numerous instances of violation, and its work will be pursued by other agencies. It has referred 200 cases to the special criminal chambers, which will now have to judge more than 1,700 alleged perpetrators of human rights violations committed between July 1955 and December 2013. Criminal proceedings have, in fact, begun in more than 100 cases.

The public and private archives collected by the IVD, the database and the single register of victims of violations are part of Tunisia's heritage. They will be invaluable to magistrates, historians, journalists and researchers. And work on memory of the repression is only just beginning. The process must not end with the demise of the Commission. It is the Tunisian people's right to know their own history that is at stake. 


\section{Notes}

1 Zine El-Abidine Ben Ali (1936-2019) was President of the Republic of Tunisia from 1987 to 2011.

2 Article 1 of Organic Law 53-2013 establishing and organising transitional justice.

3 Habib Bourguiba (1903-2000) was Tunisia's first President after independence, holding office from 1957 until 1987.

4 The report is available in Arabic on the IVD website at ivd.tn/rapport final.

5 Tunisia's internal autonomy was recognised by the Franco-Tunisian Conventions of 3 June 1955, which came into force on 31 August of the same year. On 1 July 1955, conflict began between supporters of Bourguiba, who were in favour of the agreements on internal autonomy, and supporters of Salah Ben Youssef, the Neo Destour Party's Secretary General, who were hostile to the agreements, seeing them as a retrograde step.

6 Law No. 88-95 of 2 August 1988 on archives.

7 Law No. 88-95, Articles 7 and 8. The authorities shall set the rules determining the life cycle for each type of document or record, from creation through to final destination. Their schedules set the retention periods for types of documents for current usage, for documents treated as intermediate archives when they are no longer required for current use but for legal reasons cannot yet be disposed of, and for their ultimate fate: disposal or long-term conservation as historical archives.

8 Organic Law 2017-62 of 24 October 2017 on administrative reconciliation.

9 To view the public hearing of 17 May 2017 on corruption. Available at www. ivd.tn/timeline/.

10 Supporters of the nationalist leader Salah Ben Youssef, a former associate of Habib Bourguiba who later became his main opponent. See note 5.

11 In 1957, the Beylical regime was abolished and the Republic created.

12 See notes 5 and 10. He was assassinated in Germany in 1961, a crime the IVD successfully proved to have been committed by agencies of the state.

13 A governate or wilaya is a local authority in Tunisia, equivalent to a French département. Tunisia is divided into 24 governates.

14 Statistics from the single register of victims of human rights violations published in Arabic on the IVD website.

15 Editor's note: In January 2020, despite all its reservations, the Commission was forced to transfer its records to the Tunisian National Archives, with the exception of the audiovisual archives which were deemed too sensitive and therefore consigned to the President's Office. For more information about the disagreement between the National Archives and the IVD regarding the conservation of its archives, see Nessim Znaien's article, "Les historiens tunisiens face à la justice transitionnelle: autopsie d'un conflit" [Historians versus transitional justice: autopsy of a conflict], L'Année du Maghreb, 5 December 2019. Available at http://journals.openedition.org/anneemaghreb/6078; doi:10.4000/ anneemaghreb.6078, accessed 29 January 2020.

16 The Battle of Djebel Egri-Chenini took place shortly before Tunisia gained independence. It was between Sahal Ben Youssef's supporters and the French forces, with the complicity of Habib Bourguiba's supporters, who inflicted heavy losses on the insurgents entrenched at Djebel Egri.

\section{Bibliography}

Allal, Amin, and Geisser, Vincent. 2018, Tunisie: Une démocratisation au-dessus de tout soupçon? CNRS Editions. Available at https://www.cnrseditions.fr/catalogue/ sciences-politiques-et-sociologie/tunisie/. 
Andrieu, Kora. 2014, La justice transitionnelle: de l'Afrique du Sud au Rwanda, Folio essais, Gallimard.

Basto, Maria-Benedita, and Marcilhacy, David, dir. 2017, L'archive sensible: mémoire, intimité et domination. Paris: Editions Hispaniques.

Bedoui, Abdelmajid. 2014, Grandeurs et misère de la révolution tunisienne. L'Harmattan. Available at https://www.editions-harmattan.fr/index.asp?navig=ca talogue\&obj=livre\&no=44401\&razSqlClone $=1$.

Extracts from the report are discussed on the Justice Info website in English. Available at www.justiceinfo.net/en/truth-commissions/41290-tunisia-truthcommission-report-part1-dissected-oppression.html and www.justiceinfo.net/ en/truth-commissions/41314-tunisia-truth-commission-report-part-2-justiceand-prisons-tools-of-oppression.html.

Ferchichi, Wahid, and Hached, Farah. 2014, Les archives de la dictature entre la justice transitionnelle et les questions de la sécurité (in Arabic). Dar Mohamed Ali, Tunis. Available at https://www.kawakibi.org/wp-content/uploads/2020/02/ La-recherche-scientifique-et-la-justice-transitionnelle-en-Tunisie.pdf.

The IVD's Final Report is available in Arabic on its website at www. ivd.tn/ rapportfinal.

Lefranc, Sandrine. 2018, Politiques du pardon. Paris: Presses Universitaires de France.

Nanteuil de, Matthieu, and Munera Ruiz, Leopoldo. 2013, La vulnérabilité $d u$ monde: démocraties et violences à l'heure de la globalisation. Louvain: UCL, Presses Universitaires. 


\title{
4 The exploitation of the archives of Hissène Habré's political police by the Extraordinary African Chambers
}

\author{
Henri Thulliez
}

Between 1982 and 1990, Chad was controlled with an iron fist by Hissène Habré, a man who had gained power by force, and who was subsequently driven out in the same way by Idriss Déby Itno, his former Chief of Staff and the current President of Chad. His regime was responsible for a large number of political murders, the systematic use of torture, thousands of arbitrary arrests and the persecution of particular ethnic groups. Shortly after his downfall, the survivors, the widows and the orphans began to group together in associations seeking justice. In 1998, these victims were joined in their quest by NGOs from Chad and Senegal and from international NGOs, including Human Rights Watch (HRW) which had played a particularly important role in the Pinochet case. ${ }^{1}$ Habré himself, taking with him a large amount of public money, went into exile in Senegal, where he was able to construct a particularly effective protective network. To allow the Chadian victims to make their grievances heard from the other side of the African continent, their campaign had to be made both international and professional.

From 2000, when their first complaint was made, to 2016, when the former dictator was sentenced to life imprisonment, the victims were subject to what Desmond Tutu had called an "interminable political and legal soap opera." 2 Brought before the courts of Senegal, Chad and Belgium, submitted to the chanceries of the United States, Africa, Europe and the United Nations, backed by parliaments from the United States, from the European Union or from Senegal, considered by the Court of Justice of the Economic Community of West African States and the International Court of Justice, the case of the former dictator - "the hot potato" as Senegalese journalists liked to call him - was finally heard before the Extraordinary African Chambers (EAC), an ad hoc international tribunal established by Senegal in collaboration with the African Union.

During the 16 years of this fierce struggle for justice, the victims, their legal teams and their supporters were able to write the history of those bloody years, building up an exceptionally strong criminal case which was primarily responsible for the conviction of Habré for crimes against humanity, war crimes and torture. In addition to the hundreds of witness 
testimonies and the evidence of former regime officials, the main players in the campaign for justice were able, in particular, to draw on what was a veritable mine of information proving the personal criminal responsibility of the dictator Habré: the records of the DDS, the Documentation and Security Directorate.

\section{The Documentation and Security Directorate (DDS), Habrés political police}

The DDS was created by decree of Habré on 26 January 1983. "Under the direct control" of the president, it was responsible for carrying out the repression of anyone "suspected of activities contrary or merely harmful to the national interest." ${ }^{3}$ Effectively an intelligence service responsible for Chad's internal and external security, the DDS swiftly established itself, as the EAC judges later noted, "as a machine of terror and repression" ": in practice, the remit of the DDS enabled its operatives to take action in the case of any individual suspected simply of opposing the existing regime. Simple acts, even the most innocent ones, could be construed as activities contrary or damaging to the national interest. One undated DDS document which relates to counter-intelligence defines the repression as, inter alia, a measure to end "definitively, hostile activity through physical elimination, prison, arrest, conviction or any other form of repression." 5

In order to eliminate the opposition, the DDS was structured in a way that allowed it to carry out its enquiries anywhere within Chad. In a memorandum of 26 August 1987 cited by the EAC judges, the Director of DDS acknowledged that "the DDS, thanks to its spider's web spun over the whole of the national territory, ensures the security of the state." ${ }^{\prime}$ The DDS also controlled a prison system which maintained the prison population in a number of different detention centres in N'Djamena and elsewhere in the country. Responsible for arrest, interrogation (and thus for torture), imprisonment (and thus for its inhumane conditions) and "disappearances," it was the regime's principal criminal organ and the president's sword arm. Again, in citing the same memorandum, the judges noted the hold of Habré on the DDS:

[The DDS] constituting the sinews of the state, is the responsibility of the head of state and both depends on, and is accountable to him for its activities.... As the eyes and ears of the President of the Republic, the Documentation and Security Directorate must be informed about the effective functioning of state-owned, parastatal and private services as well as the management of public funds. ${ }^{7}$

The EAC judged that Habré had exercised the power to appoint and dismiss DDS officials, that he had the power to issue orders to those officials and 
that he was involved in the day-to-day operations of the DDS and of its prison archipelago and thus ensured his control over the organization.

Given the control which Hissène Habré exercised over the DDS, the Court is in no doubt that it was Hissène Habré himself who was responsible for defining [insuffler] its overarching aims and that he played a decisive role in DDS's involvement in the repression of the Chad's civilian population. ${ }^{8}$

It was because of his control over the DDS that the judges concluded that he was responsible for crimes against humanity, on the grounds of joint criminal enterprise stemming from his role within the DDS, and, under command responsibility, of war crimes.

Proving that the DDS had committed international crimes was therefore tantamount to showing that Habre had perpetrated these crimes. The most convincing way to achieve this was through the archives of the DDS.

\section{The Commission of Enquiry and the DDS archives}

After the fall of Habré, President Idriss Déby set up, by decree of 29 December 1990, the Commission of Enquiry into the Crimes and Misappropriations committed by the ex-president, his co-perpetrators and/or accomplices. Its main objective was to shed light on the criminal activity and misdemeanours of the former regime. In his book Chronique d'une enquête criminelle nationale [Chronicle of a National Criminal Enquiry] in which he details the investigations undertaken by the Enquiry, the President of the Commission, Mahamat Hassan Abakar, explains the reasons that justified the creation of such a body in the days following the fall of Habré:

People were searching through all the political detention centres, and even the ordinary criminal ones, to find their loved ones. But there was nothing. There was no longer anyone there. The grim jails were practically empty. Only some few dozen skeletal survivors remained, starving, misshapen, scarcely recognisable and unable to walk. They were quickly rescued, either by their friends or by first aid workers from outside the detention centres. . . . It was in this context, and given these circumstances that the new masters in N'djamena decided to set up the Commission of Enquiry. It is my opinion that President Déby had at that point, no other option because thousands of members of his own clan and of his allies who had brought him to power, not to mention the other anonymous Chadians, had lost their lives in Habrés jails or had been summarily executed.

(Abakar, 2006, p. 22). 
After 17 months' work, the Commission made its report public; it detailed the Habré government's repressive methods, estimating the number of its victims at some 40,000 (Chad Ministère de la Justice, 1993, p. 97). Without its own premises, the Commission had to hold its interviews in the DDS offices themselves. It was then no doubt that the organization's notorious archives were identified. Though not giving a great amount of detail, the report is based, in part, on those documents:

The methods followed in these investigations are those used in legal processes, and specifically in criminal proceedings. . . . In short, the Commission will hear from anyone who can provide evidence to it. It will, as well, bring together written or material evidence such as lists of individuals executed or who died in detention, photographs of torture, the location of mass graves, etc.

(Chad Ministère de la Justice, p. 11)

The Commission published some 30 documents in its report, including the decree establishing the DDS, authorisations for the nominations of its members signed by Habré, lists of those arrested, imprisoned or freed, death certificates of those in custody, etc. At the end of their work, the Commission left in the former DDS building the records relating to its own work, arranged and well catalogued (Abakar, 2006, p. 123). It further recommended that the building should be turned into a museum, where the archives might be opened up to the public (Chad Ministère de la Justice, pp. 98-99). Yet some years later, when two researchers from Human Rights Watch found the records, they were in a state of incredible disorder, with some even on the floor. It was never explained why the system used by the Commission had not been retained, especially as the building and its annexes were in a secure location, in fact in the current presidential premises (Abakar, 2006, p. 124).

\section{An Eldorado: Human Rights Watch's discovery of the DDS Archives}

In 2001, while making a documentary about Habré case and following the work in Chad of HRW researchers Reed Brody and Olivier Bercault, the journalist Pierre Hazan asked the authorities for access to the Piscine (the Swimming Pool). The Piscine was the symbolic prison of the Habré regime: a former swimming pool built during the French colonial period, it was covered over with concrete slab under Habré to create an underground prison with especially inhumane conditions. It was located only a few metres from the former DDS headquarters in N'Djamena. "To my surprise" wrote Hazan some years later, "I received permission to gain access."

Accompanying the journalist and his camera, Brody and Bercault were also invited by the Chadian authorities to enter the DDS headquarters 


\section{Henri Thulliez}

which were by now practically derelict. There they discovered thousands of documents which Hazan recalls as lying on the ground and covered with a thick layer of dust:

It was a shock. We found ourselves confronted by indescribable chaos. There were thousands of papers scattered around in all of the rooms. We had to walk over them to get anywhere. They were coming practically up to our calves.... [W] had just got our hands on the archives of horror. ${ }^{10}$

Stunned by the discovery, and sweating in the 40-degree heat even in the shade, Reed Brody, standing on the filthy archives, described the scene to camera:

This is a veritable gold mine of documents relating to the regime of Hissène Habré! There are documents from his secret police, to do with the imprisonment of detainees, orders, searchers, investigations. There's real treasure here, a real treasure trove for us! It's exactly what we've been looking for two years. This is a great moment especially if we can get permission to study this material. That would be highly significant. ${ }^{11}$

In the following months, the victims' association was authorised to visit the building on a regular basis to clean, reassemble and arrange the documents. Copies were sent to HRW which started to classify them; this was, in particular, done by Patrick Ball and his team at Benetech. ${ }^{12}$ After several months, a database had been constructed to enable aid research. As Brody had predicted, the documents were going "to allow the victims to evidence the relentless system of repression set up by Habré in minute detail" (Dioh, 2003). Over and above the fact that they established the individual criminal responsibility of Habré, the DDS archives constituted a formidable tool for increasing awareness of and providing information for the victims' campaign for justice. Between 1998 and 2012, pressure on the Senegalese and international authorities was maintained to ensure that Habré's trial would finally take place. In addition to establishing the individual criminal responsibility of Habré, the DDS archives were a powerful awareness-raising and communication tool for the victims' campaign for justice. Between 1998 and 2012, pressure had to be maintained on the Senegalese and international authorities to ensure that Habrés trial could one day take place.

In 2010, Patrick Ball and Benetech published their report on human rights violations by the Chadian state under the Habré regime. Based heavily on the DDS archives to which they had been given full access, the report concludes, inter alia, that

A total of 12,321 individual victims were mentioned in the recovered and coded documents, including documentation of 1,208 deaths in 
detention. From these documents, we verified that President Habre received 1,265 direct communications about 898 DDS prison detainees. This is direct evidence that Habré's subordinates within the DDS communicated detailed information about the ongoing practices and events within the DDS prisons.

(Silva, Klingner, and Weikart, 2010)

The documents contributed significantly to the credibility of the prosecution's case, but they also made available detailed facts and figures relating to those painful years, thus raising public awareness of the importance of holding the trial. So, for example, Human Rights Watch discovered within the documents proof of the arrest and detention in the regime's jails of two Senegalese nationals. They were arrested on 25 March 1987 at N'Djamena airport. Both merchants, they had arrived in Chad from the Central African Republic on a French military aircraft with a large amount of gold ordered by French officers in Chad. An information report complied for the Director of the DDS, dated 26 March 1987, refers to the arrival of the two men on a special French army flight from Bangui. The Two Senegalese were "intercepted by the commander of SP [Presidential Security] when airport police formalities were being carried out We thought that presidential security had intelligence about them. . . . From our side there are no issues that compromise them." Demba Gaye and Abdourahmane Gueye were separated, and never saw each other again. Through the archives, it was possible to discover what happened to them in detention. According to a note dated 16 November 1987 sent to the Director of the DDS by the head of the prison service, Demba Gaye had unfortunately died in one of the regime's prisons:

I have the honour to report that on $15 / 11 / 87$ at 18.30 a prisoner named N'gaye Demba arrested by officers of the airport police on 25/3/87 Senegalese on arriving from the R.C.A. by French vam [sic], [regarded as] suspect by the national police and transferred to the D.D.S., died as a result of illness.

The person concerned is crossed off the list of our prisoners, The death certificate is attached.

The certificate, which was also recovered, contains no cause of death. However, one of his co-detainees, Clément Abaifouta, made responsible by the DDS for the burial of individuals dying in prison, testified before the EAC:

Ah, the Senegalese guy Demba Gueye, he came up to us at the Camp des Martyrs [prison], he was fit and healthy, bigger than me even but after three months he went down with dysentery, severe dysentery, and he died of it and it was me who buried him. ${ }^{13}$ 
A note from the head of the DDS prison service to the Director of the DDS, dated 3 February 1988, informed him of the release of the second Senegalese detainee Abdourahmane Gueye:

I have the honour to report that on 2/2/1988 the detainee Gaye Abdraman [sic], a Senegalese national arrested on 25 March 1987 for being in prohibited military zones was freed on order of the Director. The individual concerned was handed over to his ambassador Pape Louis Fall in the presence of the Minister of the Interior Brahim Itno. ${ }^{14}$

Although Abdourahmane Gueye was known to have survived, he was not traced until 2005 when HRW and its partner organization RADDHO ${ }^{15}$ organised a press conference in Dakar during which they encouraged anyone with information relating to the Senegalese prisoners to contact them. Shortly afterwards, Gueye himself turned up. A merchant who had travelled extensively in Africa and Europe, he recalled in minute detail the ordeal he had endured in Chad. Within the space of a few months, this retired trader and survivor of horror was a human rights activist. For the Senegalese public, he became the embodiment of the scars left by Habrés prisons and he convinced them of the necessity for Habré to be put on trial.

On 23 November 2015, supported by dozens of relatives who were there to see him testify in the court room of the Palais de Justice in Dakar, and in the presence of Demba Gaye's sister who had also been found several years earlier, Gueye related, before the former president, the horrors he had lived through in a foreign country, in the hell of an overcrowded prison. His testimony made an impression because of its precision and its emotional impact, and because his freedom had been made possible through the engagement of Senegalese diplomacy. ${ }^{16}$ Before the Court he declared:

Since that time, I've been fighting for justice, to make Senegalese people understand, because the Senegalese didn't believe it, and some individuals were protecting Habré. We needed to make the Senegalese people believe that there had been real victims, we had to tell them what we'd lived through.

In the same way, the story of Rose Lokissim allows a face to be given to one of the many who disappeared within the regime's jails. An investigation report written by the DDS gives the account of the interrogation of this exceptional woman. A number of those who survived Habré's prisons had spoken about this brave woman who never complained about detention conditions, but rather helped other prisoners to bear their ordeal. At considerable risk to herself, she recorded the names of prisoners, the dead and the missing, on scraps of cardboard she managed to get hold of with the aim of getting the information to their families in the outside world. 
Unfortunately, she was denounced, and DDS agents seized her, searched her cell and found her notes. In their report, the DDS agents wrote: "Given that she is totally unrepentant and continues to pose a threat to the security of the state, even whilst in prison, it is desirable that she should be severely punished." 17

Rose Lokissim was executed on the same day. She gave her executioners an invitation to be part of history, one which they did not fail to document: "She stated that, even if she has to die in a dungeon she does not regret it because Chad will thank her and history will tell her story." 18 Nearly 30 years after her death, her prophecy was realised: her name was frequently mentioned by her former co-detainees during the trial hearings, a documentary was made about her ${ }^{19}$ and UNESCO lists her as one of its "Women in African History." 20

\section{The use of archives by the judiciary}

Shortly after the first complaint was filed in January 2000 in Senegal, other victims, including three Belgian nationals of Chadian origin, filed a complaint against Habré in Belgium. At that point, Belgium had particularly liberal universal jurisdiction provisions and it was possible to prosecute individuals for acts of torture even if those had not been carried out on Belgian territory. Applying to the Belgian courts allowed the pressure on the Senegalese authorities to be maintained: if Senegal refused, or was incapable of carrying out a prosecution, then a European country would do so.

The Senegalese proceedings stagnated. Although less than a month after the 2000 complaint was brought, a Senegalese judge had indicted Habré for torture, crimes against humanity and acts of barbarism, the appeal court, following the interference of the Senegalese government of Abdoulaye Wade, quashed the proceedings, arguing that Senegalese courts lacked the jurisdiction to try crimes committed abroad. In Belgium, on the other hand, the authorities considered themselves to have that jurisdiction. In 2002, the Belgian investigating judge Daniel Fransen and his team went to Chad through international letters rogatory. They interviewed both victims, and former associates of Habré, visited a number of detention centres and took copies of DDS records.

It was on the basis of those documents in particular that, in 2005, Habré was found guilty in Belgium of crimes against humanity, war crimes and torture. Belgium requested his extradition, but a Senegalese tribunal declared that this decision lay outside its jurisdiction. Despite several repeated demands for extradition, Senegal continued its refusal. The dispute between Senegal and Belgium ended up at the International Court of Justice (ICJ) as the court responsible for settling disputes between nation states. 
On 20 July 2012, in a judgement which was fundamental to the interpretation of the Convention against Torture, the ICJ ruled Senegal was in breach of its obligations by failing to conduct an immediate investigation and by not submitting the case to its competent authorities in order to bring criminal charges against Habré. ${ }^{21}$ The judges were unanimous in stating that "Senegal must therefore take without further delay the necessary measures to submit the case to its competent authorities for the purpose of prosecution, if it does not extradite Mr. Habré."22 This landmark judgment was decisive: the Senegalese government could no longer justify on any legal grounds the failure to prosecute Habré.

An important change some months earlier had already suggested a reversal on the part of Senegalese authorities: in March 2012, the opposition candidate Macky Sall, who had promised to organise Habrés trial if elected, won the presidential election against Abdoulaye Wade. Within the space of a few months, the African Union and Senegal EAC had been established to organise the trial of the former Chadian dictator. The Prosecutor General, Mr. Mbacké Fall swiftly made a first visit to Chad to meet with the victims. On 30 June 2013, Habré was taken into custody. On 2 July, he was indicted by the EAC Investigating Commission for crimes against humanity, acts of torture and war crimes and placed in pre-trial detention. The investigating judges in charge led an efficient and particularly well-documented instruction. They despatched four international letters rogatory to Chad. Between August and September 2013, they visited the Piscine and the former DDS headquarters. There they retrieved the archives, packed into boxes as the victims' association and the Belgian federal investigators had left them 11 years earlier. These archives were then transferred to the N'Djaména judicial centre, a building not far from the Chadian Ministry of Justice. For several months, librarians from the Chad National Museum classified the thousands of documents.

The author remembers going into this building and being taken aback by a huge pile of records covered by a tarpaulin in the courtyard. These were the documents that had been set aside either by the judges or the librarians as being considered not relevant. One of these latter expressed his surprise to the author, mixed with a touch of sadness and satisfaction, when he saw his father's name appear on the lists of prisoners. He had never known what had happened to him after his arrest and at least he had recovered written proof that his father had been a victim of the regime. The documents were arranged chronologically and placed in boxes. The great majority of them were then scanned and given to the Senegalese examining magistrates who passed them to the lawyers for the civil parties involved and to the defence. This was undoubtedly the largest proportion of DDS archives to have been copied. The originals of the DDS archives are still (in January 2020) to be found in the premises of the N'Djaména judicial centre. The Commission's recommendation that they should be openly accessible to Chadians remains an aspiration. 


\section{The archives and the trial of Hissène Habré}

Throughout the trial hearings (July-December 2015), numerous documents were presented, particularly to corroborate information given by victims or witnesses. A number of them were to be the object of two forensic investigations. The first of these was aimed at establishing if what appeared to be the main smoking gun in the case was indeed one. In a memo dated 29 October 1984, the Chadian Minister for National Defence informed President Habre that the International Committee of the Red Cross was requesting the hospitalisation of 19 prisoners of war whose health care situation was precarious. A list of those prisoners was attached. A handwritten annotation in ballpoint pen gave the Minister a response:

Monitor the state of these prisoners of war in the hospital. From now on, no prisoner of war should leave the detention centre unless they are dead: the ICRC has allowed the escape of many prisoners of war. ${ }^{23}$

Tobyn Tanka, the handwriting expert appointed by the investigating judges, confirmed - following his analysis of a number of notes recovered during the investigation in a search of Habrés home in Dakar - that the writing was that of the former President. It was this handwritten note, among others, which helped to show that he himself was giving orders as to the conditions in which prisoners were held in detention, and that he sought to either weaken or eliminate them. ${ }^{24}$

The second expert investigation was carried out by Patrick Ball of the Human Rights Data Analysis Group (HRDAG), a North American NGO. Appointed by the EAC investigating judges to determine the mortality rate within the regime's prisons, he visited Chad in June 2014, during a visit through rogatory letters which allowed him to gather together hundreds of the daily status reports from DDS prisons. His analysis of 518 complete reports covering the days from 31 May 1985 to 31 May 1988 allowed him to calculate that there were regularly between 77 and 571 prisoners. This "statistician of human rights" was able to conclude, thanks to these documents, that "Mortality in DDS prisons, and in particular during the peak period 1 September 1983 to 31 January 1987, was hundreds of times higher than the normal mortality rate for adult men in Chad at the same period."

During the hearing, when he came to give his report, Ball concluded that mortality in the DDS prisons was substantially higher than that of the worst prisoner of war contexts in the 20th century.

Cited hundreds of times in the 681-page Decision of the EAC judges, the archives contributed significantly to the former president's life sentence for crimes against humanity, war crimes and acts of torture. In their decision, the judges, when referring to a specific fact, always referred first to 
the archives, second to the statements of witnesses and then to those of the victims. This pyramid of evidence shows the importance that the judges attached to the records.

Throughout his trial, Habré remained silent, boycotting the EAC which he considered both illegal and politically motivated. Although his lawyers had been present at some of the hearings organised by the investigating judges, their client had instructed them not to participate. On the first day of the trial, the Burkina Faso judge Gberdao Gustave Kam, EAC chairman, appointed court-nominated lawyers to defend him "in the interests of justice." These latter did not contest the evidential value of the archives. The silence maintained by Habré meant that certain lines of inquiry could not be followed, in particular those which touched on links between France and the United States and the repression. However, the DDS archives were able to provide some initial evidence of these relationships.

\section{Archives compromising France and the United States}

Throughout his presidency, Habré had the support of the United States and of France. ${ }^{25}$ At the same time as it was investigating the regime's crimes, HRW was also seeing to shed light on the aid provided by these two great Western powers. In two reports published a few days after the verdict, HRW outlined how France, and more particularly the United States, provided crucial assistance to Habré when he came to power, even though his use of brutal methods was already evident. Both countries saw Habré as a bulwark against the expansionist aspirations of Libya's Muammar Gaddafi. HRW explained in detail how the two powers continued to give him vital support even while he committed massive and systematic human rights violations.

Although the United States agreed to declassify a number of files relating to Chad, the French authorities, on the other hand, continued to refuse to do so, stating that to allow access to them would "unduly prejudice the legally-protected interests of France's foreign and defence policy." ${ }^{26}$ However, documents from the DDS archive helped lift the veil on relationships between the (French Direction générale de la Sécurité extérieure ["Directorate General of External Security" - DGSE]), the U.S. Central Intelligence Agency (CIA) and the DDS. So, for example, a telex sent from the DGSE to the director of the DDS, which was passed to President on 25 July 1988, showed that France was placing military aircraft at the disposal of the regime: "Notify the Director of the DDS that a [Transall] C-160 can be put in place for around twelve days in the second half of September for a mission of the same type as the one in June." 27

In October 1988, an officer of the Chad Air Force was arrested. On Habrés orders he was deported, with two of his colleagues, to the Tibesti 
desert, in northern Chad, on board a French Army Transall C-160. He told HRW:

It was a French army Transall which took me to Tibesti. The crew knew very well that we were prisoners. They know me because I had sometimes worked with them. The crew was made up of four Frenchmen including a pilot, a captain and a navigator. ${ }^{28}$

Other information confirmed the use of these French aircraft on Chadian soil. According to a DDS investigation report of 11 March 1986, Aleina Daouda, a Conseil démocratique révolutionnaire (CDR) fighter, "was taken prisoner of war at Oum-Chalouba" on 5 March 1986 "and transferred to N'Djamena on Saturday 8 March 1986 on board a French Army Transall." Daouda died on 2 May 1986 in a DDS prison. ${ }^{29}$

\section{Conclusion}

Passing through the hands of several national and international investigations, protected for a time by victims' associations, studied and processed by NGOs in Europe and the United States, used by Belgian and then by Senegalese court systems, the DDS archives established the accountability of Habré and allowed his trial to take place. Providing convincing and ultimately irrefutable evidence, they allowed for the deconstruction, in minute details, of the inner workings of an authoritarian system that its leaders considered opaque. Although the Chadian authorities have never actively sought to preserve them, or make them accessible, the victims' perseverance has meant that they have become indispensable. The celebrated observation of Albert Camus, paraphrasing Simone Weil, that "[o]fficial history consists of taking murderers at their word" ${ }^{30}$ can never now be applicable to the history of the Habré era.

\section{Notes}

1 See, in particular, Human Rights Watch. 1999, When Tyrants Tremble: The Pinochet Report, 1 October. Available at www.hrw.org/legacy/reports/1999/ chile/, accessed 17 January 2020.

2 Human Rights Watch. 2013, Senegal: Obama Backs Hissène Habré Court, 27 June. Available at www.hrw.org/news/2013/06/27/senegal-obama-backsHissène-Habré-court, accessed 30 January 2020.

3 President decree, No. 005/PR, 26 May 1983. Also, Jugement de la Chambre Africaine Extraordinaire d'Assises, 30 May 2016, $\mathbb{S} 436$. Available at www. chambresafricaines.org/pdf/Jugement_complet.pdf.

4 Jugement de la Chambre Africaine Extraordinaire d'Assises, 30 May 2016, \$ 437. Available at www.chambresafricaines.org/pdf/Jugement_complet.pdf.

5 Ibid.

6 Ibid. 
7 Ibid.

8 Ibid.

9 Hazan, Pierre. 2015, "Hissène Habré: le jour où nous sommes tombés sur les documents de la terreur," Le Monde, 20 juillet. Available at www.lemonde.fr/ afrique/article/2015/07/20/Hissène-Habré-recit-d-une-traque-de-vingt-cinqans_4690720_3212.html, accessed 17 January 2020.

10 Ibid.

11 Hazan, Pierre. dir. 2001, "Chasseur de dictateurs," Arte France. There is a short clip available at www.dailymotion.com/video/x34ubd.

12 Ball, Patrick. 2019, Human Rights Data Analysis Group. Profile available at https://hrdag.org/people/patrick-ball-phd/, accessed 17 January 2020. For Benetech's human rights work, see https://benetech.org/work-area/humanrights/, accessed 30 January 2020.

13 Clément Dokhot Abaifouta, CAE/09-11-2015/Habré/T36, 9 novembre 2015, p. 44. "Ah, le sénégalais Demba Gueye il était venu nous trouver au Camps des martyrs, il était bien portant il était même mieux gabarit comme moi mais au bout de trois mois, il s'est attrapé une dysenterie, une forte dysenterie et par suite de ça il est décédé et c'est moi qui l'ai enterré".

14 Available at www.hrw.org/blog-feed/trial-Hissène-Habré. "A Senegalese Merchant Testifies," 21 November 2015, which deals with both men's story.

15 The Rencontre africaine pour la défense des droits de l'homme is a pan-African human rights association based in Dakar.

16 Thulliez, Henri. 2015, "A Senegalese Merchant Testifies," Human Rights Watch, blogpost, 23 November. Available at www.hrw.org/blog-feed/trialhissene-habre. Gueye's testimony to the EAC is available at www.youtube.com/ watch? $\mathrm{v}=\mathrm{bAeUwrfhzT0}$ et www.youtube.com/watch?v=EYUoM85B72A.

17 DDS, Report of the interrogation of Rose Lokissim, 15 Mai 1986. ["Etant donné qu'elle est irrécupérable et continue de porter atteinte à la sécurité de l'Etat, même en prison, il serait souhaitable que les autorités la pénalise [sic] sévèrement.]

18 Ibid. ["Elle affirme que, même si elle doit mourir au cachot elle ne regrette pas car le Tchad la remerciera et l'histoire en [sic] parlera d'elle."]

19 "Parler de Rose, prisonnière de Hissène Habré" ['Let's talk about Rose, prisoner of Hissene Habre'], dir. Isabel Coixet, 2015, Miss Wasabi Films. Available at www.youtube.com/watch?v=FQyWXdjY1Ms\&t=748s, accessed 30 January 2020.

20 UNESCO, Women in African History. Available at https://en.unesco.org/ womeninafrica/.

21 International Court of Justice. Questions relating to the obligation to prosecute or extradite (Belgium v. Senegal)/Judgment of 20 July 2012. Available at www. icj-cij.org/en/case/144.

22 International Court of Justice, Reports of judgments, advisory opinions and orders/questions relating to the obligation to prosecute or extradite (Belgium v. Senegal)/Judgment of 20 July 2012, s.121. Available at www.icj-cij.org/files/ case-related/144/144-20120720-JUD-01-00-EN.pdf, accessed 28 January 2020.

23 "Contrôler l'existence de ces prisonniers de guerre à l'hôpital. - Désormais aucun prisonnier de guerre ne doit quitter la Maison d'Arrêt sauf cas de décès. Car, le CICR a fait fuir nombreux prisonniers de guerre."

24 Jugement de la Chambre Africaine Extraordinaire d'Assises, 30 May 2016, $\$ 2243$.

25 "US, France Backed Convicted Chad Dictator/Hissène Habré Received Support Amid Systematic Abuses," press release, Human Rights Watch, 28 June 2016. 
Available at www.hrw.org/news/2016/06/28/us-france-backed-convicted-chaddictator, accessed 29 January 2020.

26 Letter, 17 November 2014, from the Director, Archives de France, to Human Rights Watch. ["porter une atteinte excessive aux intérêts protégés par la loi pour la politique extérieure et de défense de la France.”]

27 Letter from the DDS to the President of the Republic, 25 July 1988. "Prévenez le Directeur de la D.D.S. qu'un C-160 pourra être mis en place au Tchad pour une dizaine de jours lors de la seconde quinzaine de septembre pour une mission de même nature que celle du mois de juin.”

28 Human Rights Watch, Allié de la France, Condamné par l'Afrique. Les relations entre la France et le régime tchadien de Hissène Habré (1982-1990), 2016, p. 53. Available (French only) at www.hrw.org/sites/default/files/report_pdf/ franceHabré0616frweb.pdf. A summary in English "Supported by France, Convicted by Africa France-Chad: relations during the Hissène Habré's Rule (1982-1990)" is available at www.hrw.org/sites/default/files/report_pdf/franceHabré0616en_summaryweb_0.pdf.

29 Founded in 1979, the CDR, made up predominantly of Chadian Arabs, was a political group with close ties to Libya. It formed part of the Transitional Government of National Unity (GUNT) of former Chad president Goukouni Oueddei and was a fierce opponent of the Habré regime. In 1989, the CDR signed a reconciliation agreement with Habré.

30 "L'histoire officielle consiste à croire les meurtriers sur parole," Camus, 1983, p. 391.

\section{Bibliography}

Abakar, Mahamat Hassan. 2006, Chronique d'une enquête criminelle nationale: Le cas du régime de Hissein Habré, 1982-1990. Paris: L'Harmattan.

Camus, Albert. 1983, Euvres complètes, IV. Paris: Club de l'honnête homme.

Chad Ministère de la Justice. 1993, Les Crimes et détournements de l'ex-Président Habré et de ses complices. Rapport de la Commission d'enquête nationale du ministère tchadien de la Justice. Paris: L'Harmattan.

Dioh, Tidiane. 2003, “Tchad: Les archives de l'horreur," Jeune Afrique, vol. 2200, pp. 85-89, 9-15 mars.

Human Rights Watch. 2013, La plaine des morts, Le Tchad de Hissène Habré, 19821990. Available at https://www.hrw.org/fr/report/2013/12/03/la-plaine-des-morts/ le-tchad-de-hissene-habre-1982-1990.

Silva, Romesh, Klingner, Jeff, and Weikart, Scott. 2010, State Coordinated Violence in Chad Under Hissène Habré. A Report by Benetech's Human Rights Data Analysis Group to Human Rights Watch and the Chadian Association of Victims of Political Repression and Crimes, 3 February. Available at www.hrdag.org/about/ chad.html, accessed 30 January 2020. 


\title{
5 The Gacaca archive \\ Preserving the memory of post-genocide justice and reconciliation in Rwanda
}

\author{
Peter Horsman
}

\section{Introduction}

The Gacaca Archive Project envisages the preservation, digitization and usability of one of the world's largest archives on transitional justice. The numbers are impressive: the approximately 60 million, mostly handwritten documents (in Kirwanda, the national language) contained in some 19,000 boxes, and over 8,000 audiovisual files created by the courts dealing with the perpetrators of one of the largest massacres in the second half of the 20th century, the genocide in Rwanda.

The Archive is maintained by the National Commission for Fight against Genocide (CNLG). It is also the formal client for the project which is managed by Aegis Trust. This British NGO, with a Rwandan branch, has a very good track record as it established and manages the Kigali Genocide Memorial, which is receiving tens of thousands of visitors each year. The real client, represented by CNLG, is the Rwandan people: survivors, children of victims, perpetrators, educators, lawyers, researchers; the latter two categories eventually including international stakeholders.

Together with Aegis Trust, an international consortium was formed to carry out the project, including Kings College London (Department of Digital Humanities), University of Southern California Shoah Foundation Center for Advanced Genocide Research (only for the first stage of the project), and NIOD, Institute for War, Holocaust and Genocide Studies in Amsterdam.

\section{The genocide and the introduction of Gacaca}

Rwanda is situated in Central Africa, close to the Equator. It is a small country, about the size of the Italian island of Sicily, with about 12 million citizens today - more than double the population of Sicily. Located in the Great Lakes Region, Rwanda is a lush, hilly, quite fertile country, with an agreeable tropical climate. In this beautiful country, however, a genocide took place in 1994. Over the course of around 100 days, more than 800,000 Tutsis and moderate Hutus were killed by government forces and militia.

This mass violence was part of a planned campaign. Hardliners within the ruling party and military took over power in the political vacuum that was 
created with the assassination of the country's (Hutu) president, Juvénal Habyarimana on 6 April 1994. First to be targeted were political rivals and elites and even UN peacekeepers. Simultaneously, extremist Hutus declared war against the entire Tutsi populace, which was associated with the Tutsidominated guerrilla forces of the Rwanda Patriotic Front (RPF). Through effective state bureaucracy - based on the previous colonial administration compulsion and selective incentives, Hutu authorities overcame internal antagonism to the violence, mobilized local officials and civilians and set in motion a vast extermination operation across the country. Armed with machetes, farming tools and handmade weapons, mobs of Hutu men roamed their neighbourhoods, singling out, abusing and murdering. Because of lack of mandate and sufficient military resources, the UN peacekeeping forces were not able to intervene and were even partially withdrawn. After 100 days, the RPF succeeded in taking over control over the country and ending the slaughter. These events had a devastating impact on the country; in effect, Rwanda was totally destroyed in 1994.

After the genocide, more than 100,000 Hutus were imprisoned by the new government on suspicion of having participated in the massacres. But bringing them to justice through ordinary courts appeared to be a huge challenge on account of the total destruction of the legal system. Between 1994 and 1999 , only 400 people were tried.

To speed up the process of justice, which would likely have taken decades, after long national and international debate and hesitation, a traditional court system was reintroduced, called Gacaca. This system, dating back to the 15th century, included the capability to involve the entire community in the process of justice and reconciliation. It is this particular quality that makes Gacaca unique in the world as compared to other transitional justice institutions. ${ }^{1}$

The announcement of recourse to Gacaca caused great controversy, with powerful arguments in favour and against. The supporters of applying traditional Gacaca emphasized the role of the population in settling genocide cases. They also stressed the necessity to reconstruct the social fabric. Furthermore, it was felt necessary to set up a system of justice in which the population would take part and reveal all the truth about the tragic events as well as punishing the criminals.

Generally, the population was in favour of a renovated Gacaca that would work independently from the Executive powers.

A process of sensitization was carried out in various prisons of the country in order to explain the new approach for faster and more efficient settling of genocide cases. In Rilima prison of Kigali Ngali, where the campaign was started, a committee of prisoners known as "Urumuri" was created on 12 May 1998 by the prisoners that had pleaded guilty for the crimes they committed.

This approach succeeded and many more prisoners confessed, and their experience was shared with other prisoners. The results were surprising. In 


\section{Peter Horsman}

this way, in Kigali Central Prison, testimonies were gathered with tables and descriptions for two Communes of Kigali City. They provided lists of names of the individuals originating from the two Communes who had killed, wounded and raped and the list of the property that had been looted or damaged.

\section{The Gacaca organization}

\section{Structure and competence of the courts}

From 2002 until 2012, more than 12,000 Gacaca courts were operative in local communities throughout the entire country and concluded almost 2,000,000 cases.

The main goals set for the Gacaca courts were as follows:

- To reveal the truth about the genocide

- To speed up the cases relating to the genocide and other crimes against humanity

- To eradicate the culture of impunity

- To strengthen unity and reconciliation among Rwandans

- To prove the Rwandans' capacity to solve their own problems

The organization of the Gacaca courts was based on the concept of a cell and a sector. A Gacaca court was created in each cell and in each sector. A cell is a small community (between 1,000 and 1,500 people); a sector is a small group of cells making up a village. The total number of cell courts was 9,013, at the sector level, there were 1,545 sector-level courts and 1,545 appeal courts. Districts and provinces are higher administrative levels. Initially, courts were established at higher administrative levels, districts and provinces, but abolished after the pilot phase.

In order to support, supervise and coordinate the activities of Gacaca courts, the National Service of Gacaca Courts (NSGC) was established. Over the years, the functioning and organization of Gacaca courts underwent various changes based on lessons learnt from a pilot phase.

\section{Organization of the courts}

Each Gacaca court was comprised of a General Assembly, a Bench and a Coordination Committee.

The General Assembly of each Gacaca court held an ordinary public meeting once a month and an extraordinary session wherever it was required for the good functioning of the court. This monthly meeting is aimed at evaluating the activities of the Bench and the coordinating committee.

Each bench of the Gacaca court was composed of nine individuals of recognized integrity. The members of the bench, commonly known as 
Inyangamugayo Judges, were elected by the General Assembly of the cell in which they reside. The elections of "Inyangamugayo" judges and other functionaries took place in October 2001. Initially, there was extensive citizen participation, particularly by women. Gradually the participation in the work of the courts decreased.

Because the judges were not professionals, and not even civil servants, an intensive training program was set up to prepare them for their not easy task.

\section{Jurisdiction}

\section{Categorization of crimes}

The offences constituting the crime of genocide were initially classified into four categories, modified after the pilot phase into three categories:

Category 1: the planners, organizers, instigators, supervisors and ringleaders of the genocide or crimes against humanity.

Category 2 (former categories 2 and 3): perpetrators, co-perpetrators and accomplices of murder or acts of serious violence against others, causing death; individuals who injured or committed other acts of serious violence with the intention to kill, but who did not attain his or her objective, together with his or her accomplices; those who committed, or participated in, other offences against individuals, without the intention of killing them, together with his or her accomplices.

Category 3: those who caused damage to property.

For each category, the law defined the possible sentences, depending on whether the accused pleaded guilty or not guilty. The confession of those who pleaded guilty, however, had to be approved and accepted by the court. Witnesses played a crucial role in this part of the process.

\section{Court of the cell}

The Cell Gacaca Court exercised the following main duties:

- To make up a list of individuals:

Who resided in the cell before and after the genocide Suspected of having participated in the genocide Victims and their damaged properties

- To bring together the files forwarded by the Public Prosecution

- To try cases related to properties

- To receive confessions from individuals who participated in the genocide

- To forward the files which are not in their jurisdiction of the competent courts 


\section{Peter Horsman}

Court of the sector

The court had, among others, the following duties:

- Making investigations, if necessary, on the basis of testimonies given

- To receive confessions from individuals who participated in the genocide

- To try cases falling under its jurisdiction (categories 1 and 2), after making sure that suspects forwarded to it had been categorized in conformity with the alleged offences

- Examining appeals against judgements passed by lower Gacaca courts within its jurisdiction

- Examining reports of activities from the lower Gacaca courts of its jurisdiction

\section{Procedure}

Apart from a few exceptions, all Gacaca court hearings were public; the deliberations of the judges were secret. The Bench held a hearing at least once per week. At every hearing, the President requested all people present to observe one minute's silence in memory of the victims of genocide, meditating on the effects of genocide and everyone's role to address them. People could participate actively in the hearings, as witness or to comment on witnesses, guilty pleas or the defence of the accused.

\section{Information gathering}

Starting between 2005 and 2006, information was taken from those who were accused from all Gacaca cells. The approximate number of those who were accused was 850,000 .

The information related to genocide was collected by the cell during the six general meetings. A seventh meeting was dedicated to making individual files for suspects, categorization and transfer of files to the competent court.

During the first General Assembly, judges laid emphasis on mobilizing the population on the importance of Gacaca courts and their objectives. The second meeting registered all the individuals that were residing in the cell before 6 April 1994. Next, the Court of the Cell drew up the list of individuals killed within the cell and those killed outside it. The families of the victims had thus the opportunity to know about hidden facts or additional detail where they only had fragmented information.

During the fifth meeting, an inventory of the families and their looted or damaged property was made. All the members of the same family were registered on the same form. The properties in question were publicly registered and the participants had the right to comment on the truth of declarations made.

Each participant in the sixth meeting was invited to give information on what he or she saw or heard during the genocide. The meeting was supposed 
to end with the establishment of a list of suspects. This step faced more challenges because some participants were silent or refrained from participating in the meeting because they were personally involved.

During the last meeting, the Bench ended the exercise by filling the individual files of suspects and went on to categorize and transfer files to competent courts.

\section{Validation of information}

The aim of this operation was to exhaustively present to the cell-level Gacaca General Assembly all information collected so far on the preparation and implementation of Genocide in the Cell so as to adopt them by consensus. The validation was followed by the transcription of all acquired information in registers to serve as a database for the Gacaca Court of the Cell.

The major challenge faced during the validation phase was the tendency to prematurely introduce debates which belonged in the hearings themselves, despite the clear distinction made by the NSGC between the pretrial phase of collecting information and the hearings which would follow.

\section{Drafting the list of suspects}

Drafting the list of individuals accused of having participated in genocide commonly known as the "list of suspects" was done by the Gacaca Court of the Cell based on the information validated by the General Assembly of the Cell and consequent allegations against each person. Nationwide, the total number of individuals put on the list of suspects by the end of the data collection phase, on 30 June 2006, was 818,564 suspects.

\section{Trials}

The rules and principles governing the conduct of trials have been compiled in a booklet known as "Trial procedure in Gacaca courts."

Whoever was summoned to appear before Court, whether accused, witness, victim or any other person, had to be informed in a period of at least seven days before the trial. The copy of the summons could only be displayed in public places intended for that purpose. A summoned person who refused to appear was brought in by force.

Before testifying, the witness had to swear to tell the truth. The public was reminded that refusing to testify, making slanderous denunciations as well as threatening members of the Bench or witnesses is punishable by the law.

The President then reminded the accused of the advantages of the procedure of confession and pleading guilty.

A judgement was rendered in public on the day fixed by the Court Bench. Judgements must be justified and explained. They were signed or 
fingerprinted by all members of the Court who seated in the proceedings and participated in deliberation.

\section{Appeal}

Means of appeal were the following: objection, appeal and review of judgement.

Objection could be made against all judgements passed in absentia by Gacaca Courts. The objection is brought before the Court that passed the judgement. The objection was only admissible if the absent party pleaded a serious and legitimate reason which impeded him or her from appearing in the trial concerned.

Except for judgements relating to damage to property passed by the Gacaca Court of the Cell, all cases were subject to appeal. The Gacaca Court of the Sector dealt with appeals against judgements rendered by the Gacaca Courts of the Cell of its jurisdiction. Judgements passed by the Gacaca Court of the Sector in the first instance were appealed against before the Gacaca Court of appeal of the same jurisdiction.

In specific cases, the judgement could be subject to review. The Gacaca Court of Appeal was the only competent Court to review judgements passed under such conditions.

\section{The Gacaca archive}

\section{Records creating}

The records were created within a process and a community that both were basically oral. Neither the people who created and primarily used the records were professional administrators, nor has the current archives staff any archival qualifications.

In order to support the process of information gathering and hearings, equipment comprising a large amount of booklets, and samples of forms to be filled in, note books, registers, pens and foot rulers were distributed. Instructions were given as to what records should be created, and what kind of information they should contain. Therefore, the case files have a structured character, and with sufficient knowledge of the juridical and administrative procedure, can be checked for completeness. The data registered during the information gathering phase at the cell level have been collected, validated, and copied into registers at the sector level.

\section{Archiving}

Each court created and maintained its own archive. When the Gacaca courts were closed down in 2012, the records had to be sent to Kigali, where they were stored in the compound of the national police, and court 
by court boxed separately. This means that the Gacaca archive in total contains over 12,000 fonds, varying from 1 box for the small cell courts to 15 boxes for the biggest sector courts and courts of appeal. Not all court secretaries were skilled in recordkeeping and transportation of the archives had often caused damages. As a result, the arrangement of the fonds is poor, at best the case files are kept together, but often the documents are dispersed, because of the fact that the folders didn't have binding mechanisms.

\section{Impartiality of staff}

As the records have been created by people who were emotionally involved in the process of justice and reconciliation, that is true for the archives staff as well. They all still carry their own and family histories with them - that is, as victims. The archive tells their history as well, if not personally, then at least as member of a group. Nevertheless, the priorities of their daily work is mostly retrieving files on behalf of perpetrators, leaving unprocessed records that document victims. This dilemma illustrates that seeing the role of the archivist as impartial, as sir Hilary Jenkinson famously did, is an illusion. The archivists may feel in conflict with their jobs, when they have to retrieve documents that may serve to support lawyers in defending perpetrators. They may even feel tempted to hide or destroy certain documents.

\section{Contents of the archive}

This is a dream that becomes reality. ... We need to tell the world what happened.

(Representative of the Office of the President at the project presentation on 11 December 2014) ${ }^{3}$

What history, then, does the Archive tell? It is not the story of the genocide, but stories told by the people during the hearings of the Gacaca courts. Despite the good intentions of community participation, these stories don't tell all of what happened. Participation decreased over time; witnesses and judges were threatened, intimidated and sometimes even killed; guilty pleas tended to hide rather than to reveal the truth. Equipment used for data collection (filing cabinets, books, forms, etc.) were often damaged or destroyed. Moreover, the Archive is about judging of what happened to the Tutsis, not about what happened after the Tutsis took over.

The Archive is primarily the product of the juridical procedure, the one already described. It is the bureaucratic and predesigned artefact of a series of highly oral activities. The documents are in the first place formal recordings, bearing legal value. The thousands of audiovisual recordings tell much 
better what happened during the sessions of the courts, and show emotions that the paper records never can reveal.

The Archive gives a name to victims, documents in many cases what happened to relatives and neighbours of the survivors. It gives a name to the perpetrators, as well as to witnesses. Therefore, the archive is far from an impartial source for research. Government policy is clear: these names should not be forgotten.

\section{Project}

The main task of the Gacaca Archive Project was to develop practical strategies for preservation and making the archive accessible, first of all for the staff that yearly has to respond to 4.000 requests for files - mostly from prisoners, or their lawyers but also from courts of justice dealing with appeals or requests for revision, and from immigration offices of foreign countries dealing with requests for residence permits by Rwandan citizens.

The project aimed at two strategies: stabilizing the (physical) archive and digitization, in order to achieve improved accessibility for those who have the rights to consult the records. Stabilizing the archive means at least conservation, including improving the storage. The latter is completed, thanks also to the Netherlands National Archive that provided the Archive with shelving. A program for repacking and re-boxing is interrupted in order to save costs, because chemical tests carried out by the city archive of Rotterdam proved that the current wrappers and boxes are acid-free, even if not ideal. The Archives staff has been trained in the principles of arrangement and description, based on the concept of train-the-trainer. As regards archival principles and methodologies, the training focused primarily on the most urgent needs for access: quickly finding case files relating to perpetrators, supported by improved storage and logistic procedures.

\section{Progress}

The most urgent objective is to find as quickly as possible the records, that is the case files. As previously mentioned, the staff is dealing with over 4,000 requests yearly. And responding to a request meant opening all boxes of the court involved, and gathering all dispersed documents about the case.

\section{Traditional methodology}

To obtain the main goals, short-term access for rapid retrieval of case files, and long-term opening the archive different strategies are needed. The traditional one in Archives is to bring dispersed documents to the proper file and describe them as briefly as possible: a unique number and the name of the perpetrator and its parents (for identification) was considered for the Gacaca Archive to be sufficient. Leaving out of consideration the mandatory 
descriptive elements, that is compliant with $\operatorname{ISAD}(G),{ }^{4}$ does not hinder future expansion. The short-term priorities on case files leave other parts of the archive more or less abandoned. This was the approach in which the Archives staff had been trained.

But after the training course, it became apparent that even with a minimalist approach, it might take decades before the whole archive would be arranged and described. Therefore, an alternative approach was considered based on immediate digitization, document-type recognition and identification of the perpetrators by use of the existing perpetrators databases in Excel spreadsheets. A test that should make clear which approach would be best could not yet be undertaken because of logistical problems.

\section{An alternative methodology}

The need for an alternative strategy became urgent, when, after the first stage of the project, the Rwandan government, through CNLG, decided not to wait for the physical arrangement of the Archive, but to give priority to immediate digitization. From the perspective of preservation, this decision made sense, given the far from optimal storage conditions of the Archive. From a perspective of state-of-the-art experience and improving access, the decision was at least controversial, even more because CNLG wanted to have the work done within one year, a challenge that even in countries with a long experience in archival digitization would have been almost a mission impossible. The three remaining partners of the consortium decided to accept the challenge. With support of an English digitization expert, procedures and clear instruction were written, equipment was procured and a small German firm developed the workflow software. CNLG hired temporary staff, who in shifts worked 7 days a week and 24 hours a day. The procedure was based on four main activities: document preparation, document preparation control, scanning and quality control. The staff was trained, a pilot carried out, the procedure reviewed and then the real work started. One year was too short a time, but scanning the 6 linear kilometres of documents and registers within 14 months has been an impressive operation!

\section{Metadata}

The digitized Archive is difficult to access because the scanning reflects the same disorder as that of the originals. An alternative methodology for adding essential metadata was sought, making use of the fact that almost all documents are preprinted forms, according to well-established and defined document types and that the names of the accused persons were already available, organized by court. The few metadata that during scanning were automatically captured included, apart from a meaningless document id, the information about the court that produced the document, and the bundle and box in which the originals were stored. 


\section{Peter Horsman}

The methodology, for assigning metadata essential for access, as a plug-in added to the workflow software is based on recognizing the document type, adding the document type to the metadata, highlighting the name of the accused person, so that the operator can search for the name in the database of accused persons, and linking the document to that name. This implies that the case files became virtual files, meaning those documents, such as the charge sheets, that may contain more than one name, can be related to more than one case file, something that in the paper world only could be achieved by copying the documents. The methodology now also provides an improved possibility to include the names of the victims in the descriptions. The original paper documents remain in the existing (dis)order. In case they are needed, they can be retrieved through the logistic metadata.

\section{Access}

Digitization, description and conservation now form the basis for a longterm strategy: opening the archive for Rwandans, scholars, and the international community, preserving the records as a memory of post-genocide justice.

To arrive at the second project goal, making the archive accessible for third parties, different strategies may be required, focusing first on explaining the Gacaca process and the meaning of the records. The staff who now work in the archive have knowledge about that, by personal experience, by hearsay, or by studying the legislation. But that will not be the case for future researchers, or for those who will access the archive at geographical distance. How then to explain the procedure and overall the dynamics of the archive, and to what extent are traditional archival theories, practice and standards useful?

Archival methodologies and standards are designed to describe static archives, not the dynamics of the processes that created them. The overall structure of the current ICA guidelines for archival description, identifying agents, records, functions, may serve as an overall model, but the method of representations might be different from the elements that these guidelines suggest. The thousands of videos may tell the story of how the trials worked in reality much better than a formalized description according to ISDF $^{5}$ could ever do.

A Research guide, explaining its contents and structure for generations to come will be the primary user interface, to provide long-term physical and intellectual access to the Archive. This interactive Guide is based on a highlevel system design and implementation that could not be easily provided by off-the-shelf software. The challenge was not only to develop such a tool, but also to work in close cooperation with and maximum involvement of the archives staff. The Metadata Object Description Schema (MODS) is chosen as the basic metadata standard, but additionally an inventory of the Archive will be developed by using EAD. ${ }^{6}$ 
The digitized documents are stored in a Repository (Fedora-based Islandora). ${ }^{7}$ The Guide takes the form of a website, with both static pages with the contextual information and dynamic links for retrieval of the documents from the repository.

\section{Access restrictions}

Different communities may have different, and often conflicting interests, including gaining access to all records, protecting privacy or even hiding facts. In any case, given the sensitivity of the contents of the Archive, direct access to the content will be restricted. For educational purposes, anonymized copies of documents, showing both the judicial procedure and the kind of information that the Archive maintains, will be made available. The expectation is that the Guide and the Archive will become more than legal sources providing judicial information, but, as the minister of sports and culture, Joseph Habineza, expressed during the project presentation in December 2014:

We cannot leave our history as it is now. . . [I]t should be useful for everybody. ${ }^{8}$

\section{Notes}

1 Clark, Phil. 2010. The Gacaca Courts and Post-Genocide Justice and Reconciliation in Rwanda: Justice Without Lawyers. Cambridge: Cambridge University Press, p. 3.

2 The author recalls having seen this booklet in the archive of the National Service of Gacaca courts.

3 The quote is based on the author's personal notes from the project presentation on 11 December 2014.

4 General InternationalStandard ArchivalDescription. Availableat www.ica.org/sites/ default/files/CBPS_2000_Guidelines_ISAD\%28G\%29_Second-edition_EN.pdf.

5 International Standard for Describing Functions. Available at www.ica.org/en/ isdf-international-standard-describing-functions.

6 Encoded Archival Description.

7 Islandora is a free and open-source software digital repository system based on Fedora Commons, Drupal, and a host of additional applications.

8 The quote is based on the author's personal notes from the project presentation on 11 December 2014. 
$\because$ Taylor \& Francis Taylor \& Francis Group http://taylorandfrancis.com 
Asia 
$\because$ Taylor \& Francis Taylor \& Francis Group http://taylorandfrancis.com 


\title{
6 Memory politics and archives in Sino-Japanese relations
}

\author{
Karl Gustafsson
}

\section{Introduction}

The legacy of Japanese imperialism and aggression, often referred to as the 'history problem' (see, for example, Saito, 2016; Koyama, 2018), has long been a source of tension between Japan and its East Asian neighbours. In particular, Sino-Japanese relations have been negatively affected by issues related to how the Japanese invasion of China in the 1930s and 1940s is remembered in China and Japan (Gustafsson, 2014b; Dian, 2017). For example, the Chinese government has repeatedly complained about portrayals of the war in Japanese history textbooks (Shin and Sneider, 2011) and condemned Japanese prime ministerial visits to the controversial Yasukuni Shrine, which enshrines 14 convicted Class A war criminals along with almost 2.5 million Japanese war dead (Takenaka, 2015; Cheung, 2018). At the same time, Japanese government representatives have criticized Chinese history education and war museums for being 'anti-Japanese' (Gustafsson, 2015a). In addition, during the last few years, the history issue has increasingly come to be linked with the territorial dispute over the Diaoyu/Senkaku Islands. In this context, both the Chinese and the Japanese side have made appeals for support from the international community or particular states to a much greater extent than was previously the case (Gustafsson, 2014a; Hagström, 2015; Yennie Lindgren and Lindgren, 2017). At the same time, attempts at reconciliation have at times been made (Rose, 2005; Szczepanska, 2017), and Japanese prime ministers have made numerous statements of remorse and apology (Yamazaki, 2006). Such statements, however, have often been followed by loud claims that Japan did nothing particularly heinous in the past, or at least that Japan's transgressions were no worse than those committed by other states (Lind, 2008). In China, Japanese apologies have often been seen as inadequate, while Japanese have increasingly come to believe that Japan has already apologized sufficiently or that no amount of apologies ever will suffice (Fukuoka, 2018; Gustafsson, 2019).

Archives have played a key role in reconciliation and truth commissions and in the promotion of human rights in post-conflict settings (González Quintana, 2009; Jones et al., 2013). What role have archives played in 
Sino-Japanese relations? This chapter addresses this question through an analysis of what is arguably the most notable case in which archives have affected Sino-Japanese relations: the inscription of archival documents related to the 1937 Nanjing massacre in the United Nations Educational, Scientific and Cultural Organization's (UNESCO) Memory of the World (MoW) Register. In 2014, seven Chinese archives jointly submitted a nomination for the inscription of the documents, and in 2015, the application was accepted. This chapter discusses the inscription in the context of SinoJapanese memory politics.

The next section briefly introduces the archives with which this chapter is concerned. The section that follows, which forms the main part of the chapter, discusses in some detail the uses of the archives and the role that they have played in Sino-Japanese memory politics. Finally, the concluding section discusses the Sino-Japanese case within the broader context of the potential for archives to contribute to the promotion of reconciliation and human rights. It is suggested that the case demonstrates the limitations of archives as instruments for reconciliation and human rights promotion in international settings.

\section{The archives}

In 2014, seven Chinese archives, the Central Archives of China, the Second Historical Archives of China, Liaoning Provincial Archives, Jilin Provincial Archives, Shanghai Municipal Archives, Nanjing Municipal Archives and the Memorial Hall of the Victims in Nanjing Massacre by Japanese Invaders, submitted a nomination to UNESCO for the inscription of documents related to the 1937 Nanjing massacre in the MoW Register. The nominating archives are all in possession of documents related to the Nanjing massacre.

The Nanjing massacre is a hotly debated episode in Sino-Japanese memory politics. As such, it stimulates emotional discussion at both the government and popular levels (Callahan, 2010; Schneider, 2018). While most serious historians agree that after the Japanese army captured Nanjing in December 1937 it massacred at least tens of thousands of civilians and soldiers who had surrendered, various estimates exist concerning the scale of the massacre, most notably the exact number of victims (Fogel, 2000; Yoshida, 2006). The nomination form submitted by the Chinese archives to UNESCO states:

The Japanese army carried out the massacre in Nanjing for six weeks, which inflicted an unprecedented impact on the Chinese people, especially Nanjing citizens, and brought about a traumatic memory till today. The International Military Tribunal for the Far East confirmed in its judgment that over 200,000 Chinese were killed, and over 20,000 women were raped or gang raped by Japanese army. 'These figures do 
not take into account those persons whose bodies were destroyed by burning, or by throwing them into the Yangtze River, or otherwise disposed of by Japanese'. The Nanjing War Criminals Tribunal concluded that 'at least 300,000 Chinese were killed'.

(Central Archives of China et al., 2014, p. 9)

The nomination form further states that 'the documents nominated by these institutions form a complete chain of evidence' (Central Archives of China et al., 2014, p. 10).

The nomination included three different types of material: (1) various documents produced while the massacre was taking place, including photos taken by a Japanese officer, entries in a diary written by a Chinese resident of Nanjing and film footage shot by an American missionary, (2) documents resulting from the investigations that formed the basis of the International Military Tribunal for the Far East (also known as the Tokyo Trial) and the Chinese Nationalist Government's Military Tribunal (which took place during 1945-1947) and (3) documents compiled by the People's Republic of China's (PRC) judiciary authorities between 1952 and 1956 consisting of the testimony of two Japanese war criminals (Central Archives of China et al., 2014).

Under the heading of 'Social/spiritual/community significance', the nomination form states:

These archives mean so much emotionally to the descendants of the victims of the massacre, to the citizens of the victimized city of Nanjing, and to the people of the once injured country. Today, tens of millions of Chinese and foreign people, including Japanese people, pay their visit to the Memorial Hall of the Victims in Nanjing Massacre by Japanese Invaders annually. On December 13th each year, people hold memorial services for the victims. As from 2014, the Chinese government makes December 13th a national memorial day for the whole nation to hold mourning events and convey condolences to those killed during the Nanjing Massacre.

(Central Archives of China et al., 2014, p. 10)

The Memorial Hall of the Victims in Nanjing Massacre by Japanese Invaders is one of the nominating institutions. While the memorial hall has an archival function as it houses a large collection of documents related to the massacre, it is better known as a museum which in its comprehensive exhibition focuses on the Nanjing massacre (Zhu and Zhang, 2009; Gustafsson, 2011). The memorial hall is one of the most visited museums in the world. According to an article in the China Daily, in 2014 it received eight million visitors making it the world's second most visited museum after the Chinese Palace Museum in Beijing (China Daily, 2015). 


\section{The uses of the archives and their role in Sino-Japanese memory politics}

This section explores the uses of the archives and the role they have played in Sino-Japanese memory politics. The section departs from the notion that states do not only seek security in the sense of physical survival, but also seek to secure collective memory, or the narratives that they construct about their past. They view perceived denials of these narratives as threatening and therefore seek to secure collective memory through various means, for example through the use of education and by constructing museums and monuments. They also seek to have their collective memory narratives recognized by other states and authoritative international organizations (Gustafsson, 2014a, 2014b). Against this background, the section discusses the Japanese and Chinese reactions to the inscription into the MoW Register.

Already in June 2014, after the Chinese application had been submitted, Japanese Chief Cabinet Secretary Suga Yoshihide commented that it was 'extremely regrettable' that China was 'using UNESCO for a political purpose' and that Japan had therefore protested and asked China to withdraw its application. Suga also explicated the Japanese government's official position that during the Nanjing Massacre, 'the killing of a large number of noncombatants, looting and other acts occurred', but added that 'there are numerous theories as to the actual number of victims, and the Government of Japan believes it is difficult to say with any certainty' (Suga, 2014).

In October 2015, following the inscription of the archival materials into the MoW, Japanese government representatives made several statements. Foreign Press Secretary Kawamura Yasuhisa, for example, commented:

[T] he submitted documents were based on the People's Republic of China's unilateral assertions, and the Government of Japan believes that there are obvious problems with the documents' integrity and authenticity. It is extremely regrettable that documents such as these have been inscribed on the Memory of the World Register despite continuous protests that were progressively lodged by the Government of Japan regarding its fundamental position, and such decisions pose a problem for UNESCO, as an international organization, which should be neutral and impartial.

Kawamura went on to say that Japan intended to request that the system for inscription into the MoW be reformed to prevent it from being used 'for overtly political purposes' (Kawamura, 2015). A few days later, Chief Cabinet Secretary Suga repeated the points made by Kawamura and added that 'experts have not verified whether the documents are authentic'. In addition, he mentioned that the Japanese government would look into 'possible revisions' to Japan's financial contributions to UNESCO, 'including the suspension of their payments' (Suga, 2015a). In October 2016, Suga mentioned 
that the payment had yet to be implemented and commented: 'last year various matters were decided within UNESCO without the Government's knowledge and therefore the Government would like to see that the situation is normalized before making a decision about how to respond' (Suga, 2016b). Eventually, Japan's payments for the fiscal year of 2016 were made in December 2016. At the time, Deputy Chief Cabinet Secretary Nogami Kotaro commented concerning Japan's payments for 2017 that 'the Government will make a decision taking various perspectives into comprehensive consideration' (Nogami, 2017). In other words, the Japanese government sought through financial means to pressure UNESCO to adopt the reforms it had suggested.

In November 2015, Japanese Minister of Education, Culture, Sports, Science and Technology Hase Hiroshi delivered a speech at the UNESCO headquarters in Paris, referring to UNESCO's motto that 'it is in the minds of men that the defences of peace must be constructed' and that protecting and transmitting world heritage is key to building such defences. He stressed that 'such activities in the field of culture must unite, not divide nations', 'and must be also intended for mutual understanding and solidarity among the Member States'. He called for reforms to the MoW Programme 'in order to improve governance and transparency' (Hase, 2015). Hase repeated these views in a meeting with UNESCO Director General Irina Bokova (Suga, 2015b).

Following the inscription, the issue was also discussed in the Japanese Diet. In November 2015, Inada Tomomi of the ruling Liberal Democratic Party (LDP) made a comparison between the Chinese nomination and the Japanese application for the inscription of documents related to the Siberian internment of Japanese soldiers following the end of World War II. Inada stated that unlike the Chinese nomination, the Japanese application had been made with Russian understanding and cooperation, suggesting that applications for inscription ought to be conducted in such a way. In the same session, Minister of Education, Culture, Sports, Science and Technology Hase stressed the importance of making the member states understand that UNESCO's original purpose was to deepen mutual understanding, not to cause confrontation among member states. Therefore, he argued, it was necessary to make the process of inscription more transparent and allow for states affected by or somehow related to a particular inscription to be able to access nominated materials (The 189th Diet, House of Representatives, Budget committee meeting no. 22, 10 November 2015). ${ }^{1}$ Similar statements about the importance of making the MoW Programme conform to UNESCO's original purpose were made repeatedly by Japanese government representatives at press conferences (Suga, 2016a, 2016b).

In several Diet sessions in 2016, Foreign Minister Kishida Fumio responded to questions concerning how the Japanese Ministry of Foreign Affairs was responding to the inscription. He mentioned that even though UNESCO's regulations encourage making documents registered in the MoW 


\section{Karl Gustafsson}

Programme widely accessible, it was still unclear exactly which documents had been registered. Japan, Kishida stated, sought to dispatch specialists to carefully examine the contents of the documents. However, even though the Chinese authorities had initially agreed to let the Japanese inspect the documents, they had then refused to provide them with access, citing technical problems as the reason. Kishida stated that without inspecting the documents, it is not possible to decide how to proceed (The 190th Diet, Lower House Foreign Policy Committee meeting no. 15, 18 May 2016; the 192nd Diet, Upper House Committee for diplomacy and defence, meeting no. 2, 20 October 2016).

While Japanese reactions to the inscription were very critical and took it as a reason for promoting reform of the system for inscription in order to prevent similar incidents in the future, Chinese reactions were very positive and interpreted the inscription as recognition of the official Chinese position on the Nanjing massacre. For example, the Chinese state-operated news agency Xinhua reported: 'Researchers and the public cheered as UNESCO listed Nanjing Massacre documents on Friday, saying the inscription marks an "international recognition and consensus" of records that have been distorted by the Japanese right wing' (Xinhua, 2015b). Similarly, Curator Zhu Chengshan of the Memorial Hall of the Victims in Nanjing Massacre by Japanese Invaders, the main archival institution behind the nomination, described the inscription as 'global recognition' and said that henceforth 'any act of denial will be impotent'. He described the inscription as 'a new start for research into Nanjing massacre, one of the greatest crimes ever perpetrated against humanity'. In addition, Xinhua commented: 'Historians rank Nanjing as equal with Auschwitz, which is listed on the world cultural heritage'. Jing Shenghong, a history professor at Nanjing Normal University, remarked that 'the listing has elevated national heritage to a common wealth, as a standing call to end of atrocities' (Xinhua, 2015b).

Furthermore, Chinese reactions were very critical of the Japanese protests against the inscription. For example, the Chinese Ministry of Foreign Affairs spokesperson Hua Chunying called the Nanjing massacre a 'severe crime committed by Japanese militarism' and 'a historical fact recognized by the international community'. She also remarked: 'Facts should not be denied and history not re-written' and 'urged Japan to reflect on its history, and to stop obstructing the work of UNESCO' (Xinhua, 2015a). Hua also commented that Japan had sought to 'obstruct China's application', thereby revealing its 'reluctance to face the history squarely' (Xinhua, 2015b). Similarly, Zhu Chengshan of the Memorial Hall of the Victims in Nanjing Massacre by Japanese Invaders, commented: 'Seven decades have passed since WWII, but the lessons of war have not been learned in some countries, and that is why we applied to list the documents' (Xinhua, 2015b).

These Chinese comments make it clear that the purpose of having the archival material inscribed in the MoW was to gain international recognition 
of the Nanjing massacre as it is understood in China. Elevating the Chinese national memory of the massacre to global memory is thus a way of securing this memory against what is considered denial and therefore a threat to this memory. According to the Chinese nomination form, the nominated documents 'form a complete chain of evidence' (Central Archives of China et al., 2014, p. 10). In other words, the authenticity claims made through the nomination of the archival documents are not just a matter of whether the documents themselves are authentic. Instead, the claim made is that inscription recognizes that the official Chinese account of the events that followed after the Japanese army entered Nanjing in December 1937 is itself indisputable. A detailed version of this account is presented in the museum exhibition at the Memorial Hall of the Victims in Nanjing Massacre by Japanese Invaders, one of the nominating institutions. The memorial hall functions both as an archive and as a museum and designated patriotic education site that houses not only documents and artefacts but also objects that have been created for the sole purpose of being exhibited such as statues and paintings. As a patriotic education site, the memorial hall's museum exhibition interprets the episode in terms of lessons for the present and future meant to make Chinese people support the Chinese Communist Party and its policies and to 'realize the Chinese dream'. It is thus difficult to separate the archive from Chinese collective memory and national identity. Scholars have highlighted that a positive Chinese national identity is often constructed in contradistinction to a negatively depicted Japan and that war memory plays a key role in such narratives (Suzuki, 2007; Gustafsson, 2016).

Meanwhile, in the Japanese Diet, the issue continued to be discussed. In May 2017, Shimokawa Makita of the Japanese Ministry of Foreign Affairs answered questions about how the ministry was dealing with the issue. He confirmed that Japan's request for disclosure of and access to the documents had still not been approved and that it had therefore not yet been revealed exactly what documents had been registered. He then repeated that the ministry was working hard to ensure that the MoW Programme would promote UNESCO's original purpose. He also mentioned that as part of the work to improve the MoW system for registration, UNESCO had appointed a group of specialists. This group had recently presented a progress report that suggested that applications should be posted on UNESCO's website to make it possible to provide comments and objections. In addition, the report also suggested that in the case of items that might provoke opposition, dialogues would be held between the concerned parties (The 193rd Diet, Lower House Foreign Affairs Committee meeting no. 14, 12 May 2017). In late October 2017, Chief Cabinet Secretary Suga stated that the UNESCO Executive Board had adopted a resolution calling 'on all persons at UNESCO to abide by the principles of dialogue, mutual understanding and respect and to avoid further political tensions concerning the MoW Programme', describing the resolution as being of 'tremendous significance' (Suga, 2017). 


\section{Karl Gustafsson}

At the time this chapter is being written, a working group is examining what the most appropriate legal framework for the MoW Programme and its nomination and inscription process might look like. This is done 'with a view to increasing the transparency of the nomination process in general and suggest possible solutions for the handling of contested nominations' (UNESCO, 2019, p. 5). In other words, even though the Japanese government was unsuccessful in reversing the inscription, it seems that it has been quite successful in gaining support within UNESCO for its suggested reforms (see also Nakano, 2018).

\section{Conclusion}

This chapter has discussed the inscription of Chinese documents related to the Nanjing massacre nominated by a group of Chinese archives into UNESCO's MoW Register. The chapter has highlighted Chinese as well as Japanese reactions to the inscription. It has been shown that in China the inscription was understood as recognition of and a way of securing the official Chinese narrative about the massacre. Unable to reverse the inscription, the Japanese government focused on reforming the system for MoW inscription in order to prevent the unilateral inscription of other documents related to wartime Japanese aggression by China or other states.

Through the analysis of this case, the chapter has highlighted some of the difficulties related to archives as instruments for reconciliation in international as opposed to national settings. For example, when an archive is not just an archive but is located in a museum that promotes a particular narrative about an episode, the recognition of archival materials might lend credibility to that narrative. At the same time, the opposite might also be the case: the archive's credibility could be attacked due to its association with a particular narrative. This suggests that archives that only house documents without promoting a controversial narrative and leave the interpretation of the documents to historians are more likely to promote human rights and reconciliation in international settings.

More generally, can archives still facilitate international reconciliation? What is required for them to do so? Global recognition of a particular collective memory narrative, for example through inscription in UNESCO's MoW, might function as a way of shaming or pressuring former perpetrators into adopting a more penitent stance (cf. Gustafsson, 2015b). However, such unilateral approaches may backfire, especially when the targeted state is relatively powerful. In addition, it could also raise questions concerning why some states are targeted and not others.

In order for archives to contribute to international reconciliation, it might be a necessary precondition that initiatives seeking to gain recognition for the archives are advanced bilaterally, rather than unilaterally. Bilateral agreement concerning the status of the archives and the veracity and integrity of documents might be necessary. Any initiatives by UN bodies granting 
international recognition to particular archives probably need to involve an evaluation of the veracity and integrity of documents by professional historians from both countries. Of course, the problem with such a bilateral approach is that former perpetrators might be reluctant to agree to such initiatives. Perhaps these problems can be overcome if archives in several countries agree to nominate documents related to several sensitive historical episodes at the same time. Such an approach might make it possible to avoid a situation where one state is viewed only as a perpetrator and other states are seen only as victims. Instead, it might be possible for states in the present to jointly acknowledge their different roles in and at the same time condemn past aggression and repression.

\section{Note}

1 The full Diet transcripts referred to are available in the Gikai kaigiroku (Diet proceedings) database. Available at http://kokkai.ndl.go.jp. All Diet statements have been translated by the author.

\section{Bibliography}

Callahan, William. 2010, China: The Pessoptimist Nation. Oxford: Oxford University Press.

Central Archives of China, the Second Historical Archives of China, Liaoning Provincial Archives, Jilin Provincial Archives, Shanghai Municipal Archives, Nanjing Municipal Archives and The Memorial Hall of the Victims in Nanjing Massacre by Japanese Invaders. 2014, Nomination Form, International Memory of the World Register: Documents of Nanjing Massacre. Available at www.unesco.org/ new/fileadmin/MULTIMEDIA/HQ/CI/CI/pdf/mow/nomination_forms/china_ nanjing_en.pdf, accessed 28 January 2019.

Cheung, Mong. 2018, Political Survival and Yasukuni in Japan's Relations with China. London: Routledge.

China Daily. 2015, "Nanjing Massacre Memorial Sees Record Visitors on TombSweeping Day," China Daily, 7 April. Available at www.chinadaily.com.cn/ regional/2015-04/07/content_20016034.htm, accessed 23 May 2019.

Dian, Matteo. 2017, Contested Memories in Chinese and Japanese Foreign Policy. Cambridge, MA: Chandos Publishing.

Fogel, Joshua A., ed. 2000, The Nanjing Massacre in History and Historiography. Berkeley, CA: University of California Press.

Fukuoka, Kazuya. 2018, "Japanese History Textbook Controversy at a Crossroads? Joint History Research, Politicization of Textbook Adoption Process, and Apology Fatigue in Japan," Global Change, Peace and Security, vol. 30, no. 3, pp. 313-334.

Global Times. 2015, China to Set Up Database for Nanjing Massacre Files After UNESCO Listing, 11 October. Available at www.globaltimes.cn/content/946462. shtml, accessed 30 January 2019.

González Quintana, Antonio. 2009, Archival Policies in the Protection of Human Rights. Paris: International Council on Archives. 


\section{Karl Gustafsson}

Gustafsson, Karl. 2011, Narratives and Bilateral Relations: Rethinking the 'History Issue' in Sino-Japanese Relations, Doctoral dissertation, Stockholm: Stockholm University, Department of Political Science.

_ 2014a, "Has China's Discursive Power Increased? The 'Power of the Past' in Sino-Japanese Relations," Asian Perspective, vol. 38, no. 3, pp. 411-433.

- 2014b, "Collective Memory and Ontological Security in Sino-Japanese Relations," Asian Studies Review, vol. 38, no. 1, pp. 71-86.

- 2015a, "Identity and Recognition: Remembering and Forgetting the PostWar in Sino-Japanese Relations," The Pacific Review, vol. 28, no. 1, pp. 117-138.

- 2015b, "How to Make Former Aggressors Repent Through Shaming and Praising: The Case of Sino-Japanese Relations," Global Affairs, vol. 1, no. 3, pp. 315-324.

- 2016, "Routinised Recognition and Anxiety: Understanding the Deterioration in Sino-Japanese Relations," Review of International Studies, vol. 42, no. 4, pp. 613-633.

- 2020, "Temporal Othering, De-Securitisation and Apologies: Understanding Japanese Security Policy Change," Journal of International Relations and Development, vol. 23, no. 3, pp. 511-534.

Hagström, Linus. 2015, "The Sino-Japanese Battle for Soft Power: Pitfalls and Promises," Global Affairs, vol. 1, no. 2, pp. 129-137.

Hase, Hiroshi. 2015, 38th Session of the General Conference of UNESCO: Speech by the Head of the Japanese Delegation, 5 November. Available at www.unesco. emb-japan.go.jp/pdf/SpeechHase_Eng38GC2015.pdf, accessed 31 January 2019.

Jones, Briony, Oliveira, Ingrid, and Rubli, Sandra. 2013, Archives for a Peaceful Future. Bern: Swiss Peace Foundation.

Kawamura, Yasuhisa. 2015, New Inscriptions on the UNESCO Memory of the World Register (Statement by Foreign Press Secretary Yasubisa Kawamura), 10 October. Available at: www.mofa.go.jp/press/release/press4e_000887.html, accessed 25 January 2019.

Koyama, Hitomi. 2018, On the Persistence of the Japanese History Problem. London: Routledge.

Lind, Jennifer. 2008, Sorry States: Apologies in International Politics. Ithaca: Cornell University Press.

Nakano, Ryoko. 2018, “A Failure of Global Documentary Heritage? UNESCO's 'Memory of the World' and Heritage Dissonance in East Asia," Contemporary Politics, vol. 24, no. 4, pp. 481-496.

Nogami, Kotaro. 2017, Press Conference by the Deputy Chief Cabinet Secretary (Excerpt), 13 October. Available at https://japan.kantei.go.jp/ tyoukanpress/201710/13_a.html, accessed 25 January 2019.

Rose, Caroline. 2005, Sino-Japanese Relations: Facing the Past, Looking to the Future? London: Routledge.

Saito, Hiro. 2016, The History Problem: The Politics of War Commemoration in East Asia. Honolulu: University of Hawai'i Press.

Schneider, Florian. 2018, "Mediated Massacre: Digital Nationalism and History Discourse on China's Web," Journal of Asian Studies, vol. 77, no. 2, pp. 429-452. Shin, Gi-Wook, and Sneider, Daniel C., eds. 2011, History Textbooks and the Wars in Asia. London: Routledge. 
Suga, Yoshihide. 2014, Press Conference by the Chief Cabinet Secretary (Excerpt), 11 June. Available at https://japan.kantei.go.jp/tyoukanpress/201406/11_a.html, accessed 25 January 2019.

- 2015a, Press Conference by the Chief Cabinet Secretary (Excerpt), 15 October. Available at https://japan.kantei.go.jp/tyoukanpress/201510/13_a.html, accessed 25 January 2019.

- 2015b, Press Conference by the Chief Cabinet Secretary (Excerpt), 9 November. Available at https://japan.kantei.go.jp/tyoukanpress/201511/9_a.html, accessed 25 January 2019.

- 2016a, Press Conference by the Chief Cabinet Secretary (Excerpt), 3 June. Available at https://japan.kantei.go.jp/tyoukanpress/201606/3_p.html, accessed 25 January 2019.

- 2016b, Press Conference by the Chief Cabinet Secretary (Excerpt), 14 October. Available at https://japan.kantei.go.jp/tyoukanpress/201610/14_p.html, accessed 25 January 2019.

- 2017, Press Conference by the Chief Cabinet Secretary (Excerpt), 27 October. Available at https://japan.kantei.go.jp/tyoukanpress/201710/27_a.html, accessed 25 January 2019.

Suzuki, Shogo. 2007, “The Importance of 'Othering' in China's National Identity: Sino-Japanese Relations as a Stage of Identity Conflicts," The Pacific Review, vol. 20, no. 1 , pp. 23-47.

Szczepanska, Kamila. 2017, “Towards a 'Common' View of Difficult Past? The Representation of Atomic Bombings in Trilateral Teaching Materials," Journal of Peace Education, vol. 14, no. 1, pp. 114-129.

Takenaka, Akiko. 2015, Yasukuni Shrine: History, Memory and Japan's Unending Postwar. Honolulu: University of Hawai'i Press.

UNESCO. 2019, Terms of Reference: Open-Ended Working Group (OEWG) on the Examination of the Most Appropriate Legal Framework for the Memory of the World (MoW) Programme. Paris: UNESCO. Available at https://en.unesco.org/ sites/default/files/oewg_terms_of_reference.pdf, accessed 21 February 2019.

Xinhua. 2015a, "China Hails UNESCO Listing of Nanjing Massacre Files," 10 October. Available at www.china.org.cn/world/2015-10/10/content_36785003. htm, accessed 30 January 2019.

- 2015b, "UNESCO Listing of Nanjing Massacre Shows Global Consensus," 10 October. Available at www.china.org.cn/china/2015-10/10/content_36781283. htm, accessed 29 January 2019.

Yamazaki, Jane W. 2006, Japanese Apologies for World War II: A Rhetorical Study. London: Routledge.

Yennie Lindgren, Wrenn, and Lindgren, Petter Y. 2017, "Identity Politics and the East China Sea: China as Japan's 'Other'," Asian Politics and Policy, vol. 9, no. 3, 2017, pp. 378-401.

Yoshida, Takashi. 2006, The Making of the 'Rape of Nanking': History and Memory in Japan, China, and the United States. Oxford: Oxford University Press.

Zhu, Chengshan, and Zhang, Qingbo. 2008, Qinhua rijun Nanjing datusha yunan tongbao jinianguan chenzhan tuji [Collected Images of the Exhibition of the Memorial Hall of the Victims in the Nanjing Massacre by Japanese Invaders]. Beijing: Changcheng chubanshe. 


\title{
7 The use of the archives of the Tuol Sleng Genocide Museum and the Documentation Centre of Cambodia by the Extraordinary Chambers in the Courts of Cambodia
}

\author{
Vincent de Wilde d'Estmael
}

\section{Historical, political, social and cultural contexts}

The Extraordinary Chambers in the Courts of Cambodia ("ECCC") began their work in the summer of 2006 with the conduct of preliminary investigations by the Co-Prosecutors and the holding of discussions between the national and international judges for the adoption of the Internal Rules. ${ }^{1}$ This was the culmination of lengthy negotiations between the Royal Government of Cambodia and the United Nations that were initiated by Cambodia in 1997, one year before the last Khmer Rouge leaders, occupying the border region with Thailand for 20 years, renounced the civil war and left Anlong Veng to surrender to the authorities in Phnom Penh. In the absence of credible trials ${ }^{2}$ and a willingness to try the Khmer Rouge leaders and perpetrators during the two decades following the fall of the Pol Pot and Nuon Chea regime, trials before the ECCC are the only judicial response to the abominable mass crimes (crimes against humanity, genocide and war crimes) committed during the 3 years, 8 months and 20 days that the regime of Democratic Kampuchea ("DK") lasted, between the capture of Phnom Penh on 17 April 1975 and the arrival of Vietnamese forces in the capital on 7 January 1979. Although very late, these trials are no less essential for the Cambodian people, for Asia and for the international community as a whole: they contribute to the fight against impunity against the senior leaders and those most responsible for the crimes committed; they establish the judicial truth, which is so important for the surviving victims and their families, but also for the memory of the 1.7-2.2 million dead; they also enable the active participation in the trials of the victims who were admitted as civil parties and who may benefit from symbolic and collective reparations in the absence of any individual financial compensation; finally, they contribute to the prevention of this type of dictatorial regime and the international crimes associated with it, by educating and raising 
the awareness of the population on the occasion of these trials. The substantive resources at the ECCC's disposal, the simultaneous access to all relevant evidence and the systematic analysis of this evidence also allow it to go beyond the work of the historians, researchers and other writers who have studied this era: judicial truth is more demanding than historical truth, because criminal facts must be established beyond reasonable doubt. The trials also aroused great interest among the Cambodian population, including young people whose parents and grandparents had too rarely talked about the hell they went through during that period, preferring to focus on the future by trying to dissimulate or forget the past and the depth of its traumas.

The discovery of Khmer Rouge archives in Phnom Penh and elsewhere in the country after 6 January 1979 has largely contributed to not burying past history and to establishing the facts. Thus, on 16 November 2018, the Trial Chamber pronounced its most important judgment since the establishment of the ECCC and sentenced the accused Nuon Chea and Khieu Samphan to life imprisonment in Case 002/02. ${ }^{3}$ They had already been sentenced to the same sentence in a first Trial 002/01. This second judgment in Case 002 concerned several security centres (prisons) and associated execution sites as well as work sites where the population was enslaved (work in communist "cooperatives," construction of dams and irrigation systems by hand and construction of a secret military airport). The Trial Chamber convicted the defendants for various crimes against humanity, including extermination, murder, enslavement, imprisonment, torture and persecution, as well as for the other inhumane acts of enforced disappearance, forced marriages and rape in the context of forced marriages, and various war crimes (in the context of the armed conflict with Vietnam). The judgment also recognised the existence of two separate genocides during this period in Cambodia: one perpetrated against the Cham minority and the other against the Vietnamese. This criminal case is probably the largest and most complex in the history of international criminal law since Nuremberg.

The Case 002/02 Judgment as well as the two appeal judgments issued previously (including the Case 001 appeal judgment against Kaing Guek Eav alias Duch, the director of the notorious S-21 security and torture centre) constitutes the culmination of a very long process of preliminary inquiries, investigations and lengthy trials. These proceedings were distinguished both by the volume of information to be processed, by the number of deaths resulting from the crimes committed (estimated at between 1.7 million and 2.2 million people) and the nature, gravity and duration of the international crimes committed. What makes these trials peculiar and even more complex compared to others (ICTR, ICTY, SCSL, etc.) is, among other things, the passage of time. While the ECCC began its activities 31 years after the capture of Phnom Penh by the Khmer Rouge communist revolutionary forces 
on 17 April 1975, the judgment in Case 002/02 was issued almost 40 years after the DK regime was toppled in January 1979.

\section{Usefulness of the Democratic Kampuchea archives versus oral testimony}

One knows how fallible human memory can be, especially after several decades. The older the witnesses, civil parties and accused get, the harder it is for them to reconstruct past events in all their details, and in particular to situate them in time or in chronological order: the description of a significant or traumatic event is often constant, but some witnesses and civil parties may confuse months or years all the more easily because under the Khmer Rouge regime they had neither watches, calendars nor radios and thus no precise time markers. It was therefore essential for prosecutors, investigating judges and their investigators, trial judges and parties to trials to be able to question witnesses, civil parties and experts on the basis of objective facts and precise dates as they appeared in DKera documents. Thus, the co-prosecutors relied heavily on these contemporary documents to lend credibility to the statements of witnesses or civil parties whenever they corroborated objectively proven facts. With the witnesses who were reluctant to cooperate with the judicial system because they themselves, as Khmer Rouge cadres or perpetrators, had taken an active part in the implementation of the Communist Party policies and the crimes that resulted from them, it was equally important to be able to confront them with the DK documents that detailed these policies or crimes committed.

Without the documents of the Khmer Rouge regime, only a small part of which could be found and preserved, the ECCC trials might not have seen the light of day. Without them, it would have been indeed much more difficult to prosecute the Khmer Rouge senior leaders and those most responsible for the crimes committed. These contemporaneous archives have in fact made it possible to clarify the roles and functions of the DK leaders and the various civilian and military institutions at the head of the country (and, therefore, the decision-making and chain of command), whereas there was little direct testimonial evidence on this subject. They also provided an understanding of the internal functioning of the Communist Party of Kampuchea ("CPK"), the major policies and guiding principles formulated and implemented by the country's leaders, as well as the communication between the Phnom Penh-based leaders and other senior officials stationed in the various civilian zones and military divisions of the country. Despite the destruction of most of them, the DK-era archives that were retrieved were so numerous (hundreds of thousands of pages) that when it came to determining which suspects, crime sites and types of crimes to prosecute in their introductory submissions, the analysis of these DK documents was initially given priority over the conduct of investigative missions in the field. 


\section{Nature of the archives of Democratic Kampuchea found and methods of conservation}

Among the archive lots that were not destroyed by the Khmer Rouge cadres before they fled or by simple ignorance by the population after 6 January 1979 are the following: (1) numerous documents from the S-21 security centre that were recovered at the Tuol Sleng school - the prison itself - and in the many surrounding houses that were used as places of interrogation and torture ${ }^{4}$; they are kept in original or copy form at the Tuol Sleng Genocide Museum, along with some documents from Kraing Ta Chan prison that were deposited there; (2) a batch of documents dating from 1975 and 1976 which was found in the early 1980s in a house in Phnom Penh clearly occupied by a member of the Standing Committee of the CPK Central Committee, probably that of Son Sen, the former Minister of Defence; (3) various documents collected in 1979 and in the 1980s which have been kept by the National Archives of Cambodia; (4) audiovisual archives collected and preserved at the Bophana Centre in Phnom Penh. These separate batches of DK archives, as well as other batches discovered or later returned to Cambodia, notably by researchers, journalists or former foreign communist sympathizers, were for the most part collected, categorised, digitised and preserved in their original form by the organisation Documentation Centre of Cambodia ("DC-Cam"), whose mission is to collect documents relating to this period and make them accessible to the public, either on-site or via their website. While some foreign States and individuals have returned or communicated their relevant archives to Cambodia, to DC-Cam and/or directly to the ECCC (France, the United States, Sweden), others, such as China or Vietnam, have remained deaf to the repeated requests from the DC-Cam and the ECCC to access their documentation concerning their relations at the time with the regime of Pol Pot and Nuon Chea.

Without the fruitful collaboration of the Documentation Centre of Cambodia, the Genocide Museum, the Bophana Centre and the National Archives with the ECCC from the beginning of their work, be it with the office of the co-prosecutors first but also with the office of the co-investigating judges, the various defence teams, the civil parties and the Chambers, it would have been difficult to access these numerous archives and collections of documents, then to select and analyse them. Thanks in particular to the work carried out by the DC-Cam to preserve, classify and more recently digitise these archives, it has been possible for the different ECCC actors to easily access and use them as required by the judicial process. This demonstrates the crucial role played by this type of civil society organisation firstly for the collective memory and the establishment of historical facts and, subsequently, for the judicial proceedings, especially during the long period when the priority was not to prosecute and try the main leaders and those responsible for these crimes. It is so crucial for the administration of justice to collect as much evidence as possible at the time of the crimes or just 


\section{Vincent de Wilde d'Estmael}

after they were committed that the Cambodian example has provided some lessons and has inspired, inter alia, the recent establishment by the United Nations of two impartial and independent mechanisms to collect, preserve and analyse evidence of the crimes committed in Syria and Myanmar.

The types of archives from the DK era that were used in the trials at the ECCC are varied. An analysis of the evidence used in Trial 002/02 demonstrates this. Of the 10,500 pieces of documentary evidence admitted by the Trial Chamber during the proceedings, nearly 4,000 pieces originated from the Communist Party itself during the DK regime, not counting other contemporary documents from foreign countries (including press articles, telegrams, reports and minutes of meetings about the situation in Cambodia).

Of these 4,000 documents, more than half $(2,148)$ originated from or concerned the security centres of S-21 in Phnom Penh (2,011 documents, 94\%) and of Kraing Ta Chan in Tram Kak District (137 documents, 6\%). The S-21 documents used in Trial 002/02 miraculously survived instructions from Communist Party leaders to destroy all archives before fleeing from the Vietnamese. It is questionable to this day why Duch, the director of S-21, did not see to the destruction of these highly secret documents in his security centre. Although he has stated that he did not receive direct instructions from Nuon Chea to destroy these documents before he fled, several other factors may help to answer this question: among them are negligence; the scattering of these archives; the lack of time to carry out this systematic destruction at the beginning of January 1979, at a moment when Duch urgently had to execute hundreds of prisoners on Nuon Chea's orders; Duch's conscious or unconscious willingness to leave behind evidence that he had carried out his duties in a professional and zealous manner, or even to document the crimes committed by the regime; or the surprise at the speed with which the Vietnamese arrived to capture Phnom Penh. Duch explained that Nuon Chea later severely criticised him for not destroying the archives. And for good reason: the ECCC legal proceedings were based on those archives, among other things. Moreover, these archives establish that Nuon Chea was Duch's immediate supervisor in relation to S-21 from mid-1977 onwards and the fact that numerous confessions extracted at S-21 were communicated to him.

S-21 records used as documentary evidence in Trial 002/02 include 89 summary biographies of prisoners prepared upon entry into S-21; 1,139 lists and logs of prisoners (including the name, age and former positions of prisoners, as well as their place of arrest and date of entry into S- 21); 154 daily lists of persons interrogated (mentioning the name of the interrogator and the method of interrogation used); 465 confessions extracted from prisoners, which relate to their betrayal of the Party or their status as enemies (these confessions include annotations by Son Sen and/or Nuon Chea in addition to those by Duch, as well as long lists of "accomplices" whom the prisoners were forced to denounce and who could in turn be arrested); 49 lists 
of people who were executed or who died in their cells (some with several hundred names); 118 reports and notebooks prepared by S-21 staff members; as well as dozens of photographs of prisoners (not included in the 2,011 document total), sometimes with their names on the back of the photos. In some cases, it is possible to follow a prisoner's steps in S-21 from the entry to interrogation under torture and execution whenever his/her name appears on various types of documents. The archives found at S-21 were often authenticated during the three trials conducted so far by Duch, interrogators, the registrar, photographers or guards who worked at S-21. The combination of the data contained in these S-21 documents enabled the co-investigating judges' office to determine that at least 15,101 persons had been imprisoned at S-21. Of these, only a handful of prisoners survived. The Office of the Co-Prosecutors continued this analysis by including more execution lists and photographs of named prisoners and concluded later that at least 18,133 persons were imprisoned at S-21.

This work is currently continuing after analysing additional S-21 documents that were not previously considered. However, the Trial Chamber in its Judgment 002/02 retained a very conservative number of at least 11,742 S-21 prisoners executed based only on certain categories of documents from S-21. ${ }^{6}$ Beyond the precise figures, the statistics relating to the entries and executions of prisoners in S-21 show that the years 1977 and 1978 were the most murderous years when purges among Party cadres were in full swing in many areas, regions and military divisions of the country.

Apart from the documents from S-21 and Kranig Ta Chan (two out of approximately 200 security centres in the country), the other contemporaneous archives used during Trial 002/02 have shed important light on the functioning of the regime. They included 71 minutes of meetings of the Standing Committee, the CPK Central Committee, the Military General Staff and the Council of Ministers. The more than 20 minutes of meetings held mainly in 1975 and 1976 between the DK top leaders within the Standing Committee are particularly important. They detail a number of policies, appointments and planned actions. These meetings were held weekly or more frequently in case of emergencies. Khieu Samphan himself acknowledged the authenticity of these minutes and the frequency of these meetings which he attended most often. These archives also included $100 \mathrm{CPK}$ publications, including official magazines and instructions for party members or party youth; 61 government statements, 245 activity reports of local cadres, both civilian and military; 212 telegrams exchanged between the ruling bodies and the zones and military divisions; 172 archives of the Ministry of Commerce; 271 media reports and 354 photographs and propaganda films of the regime. Among these contemporary documents, an important source of information, particularly for determining the activities of the DK leaders Kampuchea, are the transcripts of all radio broadcasts by the Khmer Rouge regime at the time, both by the CIA ("FBIS" reports)" and by the 
BBC ("BBC/SWB" reports). ${ }^{8}$ Speeches by Pol Pot, Nuon Chea, Ieng Sary or Khieu Samphan frequently appear in these transcripts. Some of these same speeches have been found in hard copy in the DK official documents as well, which makes it easy to authenticate them, given the existence of two distinct sources for speeches with identical content.

All these documents emanating from the regime have helped to establish the regime's murderous utopia, particularly through the existence of policies relating to the creation and operation of "cooperatives" (collective production units where any form of individual ownership was prohibited), to the forced movement of populations, the treatment of internal and external enemies, including targeted groups such as Buddhists, Cham, Vietnamese and former soldiers and officials of the previous Khmer Republic regime, and to the common practice of forced marriages.

\section{Reliability and authenticity of the archives of Democratic Kampuchea}

The content and truthfulness of documents issued by the regime itself can hardly be contested once they are authenticated or contain numerous internal or external indicia of reliability (such as general appearance, headings and emblems, language and style used, handwriting, signatures, consistency of content mentioning known events or the names of Khmer Rouge cadres or of proven victims). The contemporaneous documents proposed by the parties were generally found admissible by the Trial Chamber, and the allegations of forgery or lack of relevance and reliability made by the Defence were overwhelmingly rejected. Regarding the collection, preservation, archiving and chain of custody of the contemporaneous documents obtained by the ECCC from DC-Cam, its leaders Youk Chhang and Vanthan Dara were questioned at length by the judges and the parties in court. The Trial Chamber concluded that the methodology used was reliable and that the contemporaneous DK-era documents originating from DC-Cam were presumed to be prima facie relevant and reliable, including with regard to their authenticity, and that there was no reason to fear that the documents originating from this source could have been subject to tampering, distortion or falsification. ${ }^{9}$ The Supreme Court Chamber validated this finding on appeal. ${ }^{10}$ The Trial Chamber also found that all parties to the trials had had equal access to all the archives from DC-Cam. Once the documents were found admissible, the Chamber assessed their probative value on a case-by-case basis. It should be noted that a very large number of DK documents were authenticated during the hearings by former Khmer Rouge cadres, including Duch and other S-21 cadres, but also by senior CPK cadres, as well as by Khieu Samphan during the investigation phase. Finally, it was considered that many facts and names 
mentioned in these DK documents had been corroborated by numerous other independent sources, including other contemporaneous documents collected in other places. Only a few documents proposed by the parties were rejected by the Trial Chamber under the criteria set out in Internal Rule $87(3),{ }^{11}$ generally because they were deemed unreliable or irrelevant to the scope of the trial, or sometimes because they were illegible. ${ }^{12}$

With regard to the documents found at S-21, and in particular the "confessions" forcibly obtained from the prisoners, the Trial Chamber has clarified in its jurisprudence that extremely narrow limits have been imposed on the use of evidence containing information obtained under torture, pursuant to Article 15 of the United Nations Convention against Torture. Thus, it was held that confessions obtained under torture in S-21 could only be used as evidence against the persons accused of torture, and only to establish that the confessions had been made, and not to prove the truthfulness of their contents. However, the Trial Chamber deemed that limited objective information appearing in the documents containing the confessions (such as the identity of the prisoner and the date of his/her arrest or execution) was not part of the statements obtained under torture themselves and could be used. The same applies to the handwritten annotations by Duch, his interrogators, or by Son Sen and Nuon Chea in the margins of the confessions. These annotations indicated, inter alia, to whom the confessions were communicated and what type of torture had been applied in order to obtain the prisoner's full confession. ${ }^{13}$

\section{Conclusion}

The trials of the senior leaders and those most responsible for the crimes committed between April 1975 and January 1979 in Cases 001 and 002 were initiated and completed largely due to the discovery and proper preservation of documents from the Democratic Kampuchea era. These were considered by the Extraordinary Chambers to be among the most important and reliable sources of evidence. The additional insights provided in court by witnesses, civil parties and experts on the content of these documents and their in-depth analysis by the parties and the judges enabled the Chambers to establish the judicial truth about the charges brought against the accused and to offer certain forms of collective reparations. When the judicial proceedings have been completed at the ECCC, all the evidence documents that make up the ECCC's files, whether from the DK-era or after January 1979, will enable researchers, historians and jurists to draw from them the information they need to continue their work and thus further contribute to the preservation of memory. At present, it has not yet been determined which state organ(s) or which independent body(ies) will be the depositories of these archives. What matters is that, like the archives 
of the Tuol Sleng Genocide Museum and those collected and catalogued by the Documentation Centre of Cambodia, the ECCC's records should be kept and preserved by a credible, independent and neutral institution offering free and easy access to the Cambodian population and to foreigners interested in these subjects.

\section{Notes}

1 Adopted on 12 June 2007 and amended several times since then.

2 A symbolic trial in absentia was indeed organised in Phnom Penh by the Vietnamese authorities against the accused Saloth Sar alias Pol Pot and Ieng Sary alias Van (before the People's Revolutionary Court). It lasted only two days and a judgment was pronounced at its end on 19 August 1979. Although a great deal of evidence was presented and witnesses for the prosecution were indeed heard, the absence of the accused and the failure to respect defence rights removed all credibility from this hasty form of justice, devoid of impartiality and independence. There has been no other major attempt to try the perpetrators of the crimes committed under Democratic Kampuchea since then.

3 The two other accused in Case 002, namely Ieng Sary, Deputy Prime Minister and Minister of Foreign Affairs (and member of the Standing Committee of the Communist Party) and his wife Ieng Thirith, Minister of Social Affairs in charge of the entire health sector under the DK regime, could not be tried. Ieng Sary died of illness during the Trial 002/01, on 14 March 2013, while his wife had previously been declared unfit to stand trial due to dementia in November 2011. She subsequently died in August 2015.

4 The recovered documents do not constitute the totality of the documents established in S-21. Many of them were used in the months and years following the Khmer Rouge leaders' flight as wrapping paper for foodstuffs at the nearby Tuol Tumpoung market; others were used as fuel or were thrown away or buried out of ignorance by a population - often uneducated - whose sole concern was to ensure its survival after the fall of the regime.

5 The S-21 Security Centre is a crime site in case files 001, 002 and 003. The latter case concerns accused Meas Muth, commander of the Navy and of Division 164 within the Revolutionary Army of Kampuchea and secretary of the Kampong Som Autonomous Sector.

6 ECCC, E465 Case 002/02 Judgment, 16 November 2018, para. 2542.

7 Foreign Broadcast Information Service.

8 Summary of World Broadcasts (by the BBC).

9 ECCC, Case 002 E185 Decision on Objections to documents proposed to be put before the Chamber on the Co-Prosecutors' Annexes A1-A5 and to documents cited in paragraphs of the Closing Order relevant to the first two trial segments of Case 002/01, 9 April 2012, para. 28. The principles established in this decision were confirmed in Judgments E313 (Case 002/01), 7 August 2014, para. 34 and E465 (Case 002/02), 16 November 2018, para. 46.

10 ECCC F36, Appeal Judgment, Supreme Court Chamber (Case 002/01), 23 November 2016, paras 373-375.

11 ECCC Internal Rule 87 (3) provides that "The Chamber may reject a request for evidence when it finds that it is: (a) irrelevant or repetitious; (b) impossible to obtain within a reasonable time; (c) unsuitable to prove the facts it purports to prove; (d) not allowed under the law; or (e) intended to prolong proceedings or is frivolous." 
12 Thus, in the same Framework Decision on E185 of 9 April 2012 (Case 002/01), the Trial Chamber refused the admissibility of 10 documents (out of more than 1,400 documents) because 9 of them were deemed irrelevant and unreliable and 1 was illegible; ECCC, E185/1 (Case 002/01), 3 December 2012, Decision on objections to documents proposed to be put before the Chamber in Co-Prosecutors' Annexes A6-A11 and A14-A20 and by the other parties [7 documents were found inadmissible for irrelevance out of a total of 3,595 documents, a majority of which originated from Democratic Kampuchea].

13 See, for example, ECCC, E465, Case 002/02 Judgment, 16 November 2018, para 74-77. 
$\because$ Taylor \& Francis Taylor \& Francis Group http://taylorandfrancis.com 
Europe 
$\because$ Taylor \& Francis Taylor \& Francis Group http://taylorandfrancis.com 


\title{
8 Spanish military documentation on the Civil War and the dictatorship as an instrument of legal reparations for the victims of the Franco regime
}

\author{
Henar Alonso Rodríguez
}

\section{The memory condemned}

More than 40 years after the end of the dictatorship in Spain, and more than 80 years after the end of the bloody war that gave rise to it, Spanish society has not yet completed that 'model' transition that has received so much praise in some respects. And it has not done so because it is precisely this transition that has prevented a desirable break with the previous regime in many aspects, one of the most important ones being the use of state-led violence against the so-called enemies of the regime, most of them citizens with political ideas contrary to those imposed by the victors of the Civil War. The political, social, and, above all, legal configuration of Spain's Transition, in a way, condemned this memory of the past to being forgotten, and this is also reflected in the handling of the documentation of Franco's institutions of repression in general, and of the military authorities, in particular. Subsequent attempts to remedy this situation, such as the enactment of the 2007 Historical Memory Law, have not achieved the desired objective of establishing a clear distinction between what the events were, as they occurred (history) and what each person or social group experienced (memory), resulting in

a phenomenon contrary to the memory of history, little and poorly known, but which brings together a large part of Spanish society, not necessarily of a conservative bent. It is not historical revisionism that has permeated society but rather a negative perception of this memory and of those who claim it as a necessity, accused of stirring up the past for obscure reasons; a negative integration, anchored in the development of the Transition up to our times, which has, in the end, forged a reality of conflicting memories, complex and contradictory, which still exhibits the effects of what was the longest dictatorship in Western Europe.

(Gomez Bravo, 2014)

This continuity, without any institutional breakdown of the institutions holding political and social control under the Franco regime, and their 


\section{Henar Alonso Rodríguez}

almost automatic transformation into fully democratic institutions under the Spanish Constitution of 1978, meant that practically all the documentation they produced, including information on state-led repression, remained for a lengthy period of time under the control and in the custody of these inherited institutions, frequently even under the very individuals responsible for the previous regime, without the need for their preservation, organization, description or access to them being adequately guaranteed.

This situation was compounded by the move, detailed in Article 2(e) and (f) of the 1977 Amnesty Act ${ }^{1}$ and still in force today, which extended this measure to 'crimes and offences that may have been committed by the authorities, officials and agents of public order, on the occasion of, and as a result of, the investigation and prosecution of acts included under this Law' and to 'offences committed by public officials and law enforcement officers against the exercise of the rights of persons', which is a de facto imposition of the duty to forget, to not demand responsibility, to not want to know, and to not want anyone to know (González Quintana, 2007, p. 3).

Numerous social organizations have attempted to challenge this situation, using the inapplicability of this Amnesty Act as a justification, because crimes against humanity are never subject to a statute of limitations and because they contravene the general principles of law recognised by the international community, and of those that defend universal jurisdiction, including Amnesty International, Human Rights Watch, the Fibgar Foundation, and others. Again in 2018, the first timid legislative steps were taken towards creating institutions of transitional justice in Spain, as could be deduced from two bills presented during the 12th term of democratic office in the Spanish Parliament. These were aimed at improving the Law on the Historical Memory in this area. ${ }^{2}$ However, due to the political volatility reigning in Spain over the course of 2019, it was not easy to ascertain whether or not these would finally be implemented in practice. The possible implementation of a Commission for Truth in Spain, or the recovery of the full applicability of Universal Jurisdiction in Spain, which was reduced after the reforms of the Judiciary's Organic Law in 2009 and 2014, in any case, implied the urgent need to implement an archival policy which would favour promoting document fonds related to Franco's repression. These could thus be used for reparations to victims, and, if possible, even to demand accountability from guilty parties, to definitively bring to an end this 'transition from amnesia' which has gone on far too long.

\section{The 'archival policies' of military documentation during the Civil War, the dictatorship, and the Spanish Transition: from the destruction of the memory to forgetting}

It is important to analyse how the military documentation produced during the Civil War, the Franco dictatorship, and the Transition was handled historically in order to be able to establish clear conclusions about the selfinterested use of archives, both for the legitimisation and/or delegitimisation 
of political systems - and for the persecution and/or concealment of crimes committed. Based on the premise that throughout the 20th century and even at the beginning of the 21st century, the military archives have been kept practically independent from the remainder of public administration archives (González Quintana, 2006, p. 120), it is also fundamental to review the way in which some of the most important of these archives have been compiled, and the circumstances which characterise them.

During the war, the military documentation amassed by the two armies was also used as a weapon of combat for purely military tasks, such as obtaining information about the enemy, as an object of propaganda, and, above all, as a justification for each side's own actions, as well as evidence of each side's charge against the enemy. Document seizures and requisitions were constant, especially on the part of Franco's rebel Nacionales, while the government of the Republic collected documents more for the purposes of compilation than inquisition.

We owe the first 'War Archive', as such, to an Order of the Republican Ministry of Public Instruction, which, in the Gazette of the Republic of 17 August $1937,{ }^{3}$ ordered that both public and private bodies collaborate in the compilation of printed material produced 'as a result of current events', for that War Archive.

With the background of a provision from the Propaganda and Press Delegation of the Madrid Defence Board (Junta Delegada de Defensa de Madrid), which ordered that one of the three copies of the graphic documentation that was subject to censorship should become 'the archive of the revolution', its purpose was mainly of a propagandistic nature, with little structure, temporary, and limited almost exclusively to printed publications. With more of a cultural and participatory slant, it was aimed at justifying the anti-fascist struggle. With the capture of Barcelona by Franco's troops, the documentation that formed part of that first 'War Archive' was requisitioned and seised, and a small part of it ended up in what is now the Document Centre of the Historical Memory (Centro Documental de la Memoria Histórica), which contained information on its operation and its custodians. The remainder, mainly the collection of publications and printed matter, never left the city and is now housed in the Pavilion of the Republic, in the University of Barcelona Library (Pastor Núñez, 2019).

Nevertheless, without a doubt, the best-known 'archives of the Civil War' are those that emerged from the enormous process of seizing and requisitioning documentation obtained from military units, public bodies and political and social republican organizations, and from private homes and those who were killed or captured by troops of the so-called national side. This documentation was to be continuously and intensively used by the dictatorship with two clear objectives:

- The legitimisation of the coup d'état, the region-by-region occupation of the Civil War as a 'liberating' action, the 'unrest' provoked by the Republic, and the exaltation of the figure of General Franco. 


\section{Henar Alonso Rodríguez}

- The persecution and repression of those defeated in the 'Campaign of the War of Liberation' and of those who opposed the subsequent 'National Movement', based on personal information obtained from that documentation.

To this end, in order to build and impose an 'official memory' and justify the persecution of the adversary, it was necessary to collect, select, organise, and describe in detail all the documentation that could be obtained.

The first orders to gather documentation came precisely from the Generalísimo's headquarters, the nerve centre during the entire length of the war, which handled both the ordinary tasks of assistance and advice to the military command and the extraordinary tasks of public order and social control of the areas occupied by Franco's army.

The Office of Information and Anti-Communist Propaganda (OIPA: Oficina de Información y Propaganda Anticomunista), the National Delegation of Special Services, focused particularly on the collection of documentation from secret and Masonic societies, and the Document Retrieval Service were all created consecutively to preserve the documentation gathered by military units as the fronts developed. Later, in the final stretch of the Civil War, the system of requisitioning and seizure of Republican documentation by Franco's troops was perfected, through the creation of the State Delegation for the Recovery of Documents, then dependent on the recently created Ministry of the Interior, but still directly subordinated to the military authorities through, once again, the Generalísimo's HQ (Espinosa Romero, and Rodríguez López, 2015, p. 133 and the following). In fact, the document fonds compiled by these institutions were sent to - and finally located in - Salamanca, the usual headquarters of the Generalísimo, and are the origin of today's General Archive of the Civil War housed in the Document Centre of the Historical Memory.

It was precisely from those headquarters, shortly after the end of the Civil War, that General Franco ordered the collection of his own military documentation and that of the Republican side, first by means of telegrams sent to the generals in charge of the two armies and then by issuing a general instruction with regulations for classification, arrangement, and forwarding of the documents by the different units to the 'Historical Archive of the Campaign', which was being set up in Madrid under the orders of Colonel of the General Staff, Eduardo Fuentes Cervera, at the headquarters of the then Central Library in Calle Mártires de Alcalá.

The instruction provided for the classification and ordering of documentation for both the Republican and National side, organised by organizations and military units, and arranged according to sections of the General Staff, with six divisions: organization, information, operations, services, cartography and miscellaneous. The instruction was completed with rules for forwarding documentation, both the documentation itself, suitably marked as 'National Documentation', and the documentation requisitioned 
by the units from the defeated People's Republican Army, marked as Red Documentation.

The creation of the Military History Service (SHM: Servicio Histórico Militar) a few months later, ${ }^{4}$ in the custody of the army's Central Staff, gave this newly opened organization a legitimacy and an organic structure that was to remain constant practically throughout the Franco period and which was mainly devoted to the enormous task of classifying and ordering all the documentation sent by the units, in line with the 1939 Instruction. ${ }^{5}$ Between 1939 and 1944, fonds taken from the archives of the State Delegation for the Recovery of Documents were transferred to the now strictly military 'Archive of the War of Liberation' (Espinosa Romero, and Rodríguez López, 2015, p. 141). It was also the Military History Service, adopting the same criteria, which organised and classified part of the collection of the Spanish Volunteer Division (Blue Division: División Azul), which included it within the so-called Archive of the War of Liberation, and also produced several document compilations with the material received entitled, 'Secretarial Work', 'Mine War', and some revealing 'Political Background of the Republic', among others.

Subsequently, during the dictatorship, documents of historical importance continued to be sent to this Military History Service, such as the socalled Ifni-Sahara Campaign and the History Commission for Equatorial Guinea. During the democracy, the 'Archive of the National Militia' was added to these document collections, with documentation from the former regional, provincial, county, and local militia headquarters and those of the Military Information and Police Service (SIPM: Servicio de Información y Policia Militar) which, since its dissolution in 1939, had remained in the Internal Information Section of the General Staff's Information Division. In 1994, all these holdings were transferred, giving a definitive identity to the General Military Archive of Avila (Alonso Rodríguez, 2012, p. 4).

What the two document volumes have in common is that they were compiled, selected, organised, and described in detail for the purpose they were intended for. Those that are currently housed in the Military General Archive of Avila constructed and disseminated the 'official memory', thus legitimising the coup d'état and the subsequent Civil War as a response to the 'excesses' of the Republic. This was achieved through the decontextualisation of the scant 'Red Documentation' which the military officers themselves requisitioned, choosing the version that best justified those excesses, with an exaggerated estimation of the extremely abundant 'National Documentation', which praised the 'liberation' of the military occupation by the national forces, highlighting, moreover, the figure of the dictator by including among that documentation the documents from the Generalisimo's own Headquarters (Rial Quintela, 2017).

The documentation that remained in Salamanca, managed from 1944 by the National Delegation of Document Services under the Government Presidency, was used as a source of information on the military, political, and 
social background required by both ordinary jurisdiction and the military courts or the special courts for Repression of Freemasonry and Communism and that of Political Liability, for the information services of the general staff of the three armies and the Guardia Civil, and also for the General Directorate for Security, in charge of public order and which the much-feared Political-Social Brigade reported to. So, these served as separate elements of conviction to be used against the 'enemies of the regime' in each and every repression and weeding procedure to which they were subjected, whether of a criminal, economic, or administrative nature (Espinosa Romero and Rodríguez López, 2015, p. 147).

It is therefore essential to emphasise the real importance of the selfinterested handling of this documentation, of that 'archival policy' applied during the Franco regime, aimed at 'destroying the memory' of what the Republic was and what it meant, because, even today, both access to the archives and particularly the interpretation of these to a great extent determine their possible usefulness as instruments for legal and moral reparations for the victims of human rights violations during that period.

Another common characteristic of the two archives cited is that access to the documents was very restricted, practically limited to internal users: military historians, almost exclusively in the Military History Service, and legal, military, and administrative personnel in Salamanca. With the arrival of democracy and the suppression of the National Delegation of Document Services, the decision by the first government elected by ballot box was that its collections should be integrated within the National History Archive, at that time termed the 'Civil War Section', even though they remained in Salamanca. Precisely, this decision was what enabled the collection to be opened up to research for historical purposes. Similarly, and now after the promulgation of the 1978 Constitution, whose Article 105(b) established the right to access the archives and public records, the Military History Service also began to receive civilian researchers. However, in neither case was there any question of allowing access to the documentation for the purposes of historical research.

At no time was the possibility of using this access to analyse the potential of this documentation to ascertain the functioning of the state's repressive organizations during the dictatorship, nor the names of those responsible, nor to assert the rights to reparations of the victims of human rights violations (González Quintana, 2006, p. 136). The Civil War and the Dictatorship were already history; a history that, at last, any interested party could investigate and write about, but nothing more than that: a history, moreover, based on document holdings which were subjected to self-interested archive treatment, and which distanced them from an objective and impartial view of real events, and which, moreover, continued to be managed by the same people and the same institutions as in the previous regime, with hardly any changes. This permitted the dissemination of this 'alternative memory', which the Franco regime constructed at the time, to then be 
extended over time, significantly reducing the possibility of making use of this documentation for decades, for the purposes of reparations.

\section{The summary trials of military justice during the Civil War and the Franco regime: possibilities of applying an archival policy for the democratic memory}

The reaffirmation of this reality can be found, precisely, in the 1998 Regulations on Military Archives (RAM ${ }^{6}$ : Reglamento de Archivos Militares), which created the Defence Archive System and regulated the technical procedures and minimum material and personnel requirements needed by the military authorities to take responsibility for its document heritage. This regulation is highly specific in establishing the regulations on citizen access to the use of military documents, given the special sensitivity of the information contained in some of the document collections they hold. These RAM regulations recognise the right of free access with the typical limitations of state security and the right to the protection of the honour and privacy of individuals; however, it establishes the need to make public all the series excluded for those reasons and allows access to be requested. The Military Archives Regulations and this general system of access apply to all the collections managed by Military Archives except, as laid down in its Third Additional Provision, the documentation of the Military Court and Tribunal Archives. ${ }^{7}$ Consequently, all documentation produced by the military jurisdiction is outside the RAM, including one of the main sources for the study of the repression of the Franco regime, the so-called Summary Procedures. This abandonment of Military Justice archives to their fate meant that for decades this documentation was still held in the archives of the organizations that had produced them, although due to their age and disuse, they must have been transferred to general or historical archives, under the responsibility of a limited number of personnel in unsuitable facilities. These circumstances, of course, made it very difficult for researchers or those implicated by them to gain access.

The Historical Memory Law of $2007^{8}$ is a turning point in that it specifically mentioned the illegitimacy of all the courts which had been responsible for the repression during the Dictatorship, specifically including the War Councils, and their sentences and sanctions (Article 2), while at the same time guaranteeing the right of access to all public and private archives which contained documentation on the Civil War and the Dictatorship (Article 22). Under these provisions, two years later, the Regulations on Military Court Archives ${ }^{9}$ were finally enacted, a matter which, as in the case of the RAM, had been left pending in the Royal Decree of $2003^{10}$ on the modernisation of court archives.

An essential tool for accessing these holdings was the Guide to locating Court Proceedings initiated by the Military Justice system after the Civil War and during the Franco regime (Guía para la localización de Procedimientos 


\section{Henar Alonso Rodríguez}

Judiciales incoados por la Justicia Militar a raíz de la Guerra Civil y durante la etapa Franquista), ${ }^{11}$ produced in October 2015 by the technical staff at the Ministry of Defence. It describes both the physical location of each of the archives which contain these cases and the system for access to each of them: free and unrestricted if the holdings have already been transferred to general and historical archives, and upon request for authorisation from the military court authorities responsible for the custody of archives which have not yet been transferred. It also explains the share-out of the cases between the three armies (land, sea and air) and the current military court set-up, also assisting in the regional location of cases by the province where they were held, accompanied by a map of the regional organization of Military Justice, which can be consulted on the Ministry of Defence's Memoria Histórica website. ${ }^{12}$

As the Location Guide itself indicates, access to documentation for consultation purposes requires the prior authorisation of the military court authority responsible for its custody, except in cases where, in practice, it has been opened, on becoming part of the two military history archives that currently houses it: the Air Force History Archive, in Villaviciosa de Odón, and the most recent of the military archives created - the General and Historical Defence Archives - in Madrid. The first contains the court holdings produced by the Spanish Airforce's Central Jurisdiction, and the second, those of the First Regional Military Court. In both cases, there are name indexes and inventories of the court cases and purification dossiers, which enable location of the documentation through the names and surnames of the interested parties. ${ }^{13}$ However, the most important part of the summary trials is still in the possession of the auditors and rapporteurs of the Territorial Military Tribunals (TMT), in some cases deposited in appropriate facilities, and the investigations, searches, and organizational work on this documentation benefit from the support of the archivists of the Defence Archive System (North-west, Pyrenean, and Ceuta Intermediate Military Archives, in the case of the Spanish army; the Naval Archives of San Fernando, the Canary Islands, Cartagena, and Ferrol; and the Central Archive of the Armada Headquarters). In other cases, however, these records either lack adequate archive management and public handling, because they remain in the hands of the corresponding military court authorities, or have no opportunity for use as they are located in other military installations, constituting mere document stores that could hardly be considered archives as such.

The summary procedures are of vital importance for the implementation of legal reparations for the victims of repression under the Franco regime. And this is due to the fact that the validity of the military jurisdiction typical of wartime was extended beyond the armed conflict itself, even reaching the commencement of the Transition. This was also the case because this evidence is a faithful reflection of the generalised repression used as a system of social purging, together with maximum speed of processing and 
scarcely any procedural guarantees. Defence was almost testimonial, when not directly distorted, provoking extremely harsh sentences of an exemplary nature, which were usually applied to both ideological behaviour - qualified as crimes of treason, sedition, and aiding rebellion - and those acts which were described as common crimes: robbery, kidnapping, theft, banditry, sabotage, etc. (Rial Quintela, 2017). Therefore, the summary proceedings, due to their special characteristics, make up a document type that may contain data as relevant to processes of legal redress as the actual names of each and every person involved in the case, both the defendants themselves and the public officials and witnesses who intervened in each phase of the proceedings. Furthermore, from their reading, it is also possible to extract relevant information about the political and social circumstances that gave rise to the crimes being tried, above all based on witness testimonies, and the literal nature of arrest and search reports, cross-examinations, etc.

A clear example of the potential of summary proceedings as instruments of legal reparation for the victims of the Franco regime can be found in the decision taken by the Catalonian Regional Government (Generalitat de Catalunya), through its 2017 Legal Reparations Act ${ }^{14}$ for the Victims of the Franco regime. Its sole article declares the courts of the War Audit of the Army of Occupation as illegal. This was subsequently the War Audit of the IV Military Region, which acted in Catalonia from April 1938 to December 1978, 'declaring null and void all the sentences and resolutions of the cases instructed by war councils dictated by political causes' in the territories of the four Catalonian provinces. The real effectiveness of this regulation is completed with the authorisation to the National Archive of Catalonia to draw up and make public 'a list of proceedings conducted and sentences adopted' during this period 'in which the case number, the natural or legal person charged, and the sentence imposed are recorded' (First Final Provision). This 'list' is the final result of a complete archive management process, undertaken following a collaboration agreement between the Catalonian regional government, the Generalitat de Catalunya, and the Ministry of Defence, in which several archivists participated over a period of almost ten years. This process is described in detail and explained in the specific section of the project on the website of the Arxiu Nacional de Catalunya. ${ }^{15}$

The law which ordered the publication of what, in principle, is an instrument of description implied that this inventory was given legal validity in order to achieve the aim pursued, which was none other than to issue individualised certificates declaring, on the part of the Catalonian regional government's Department of Justice, the nullity of the sentences and resolutions of the repressive bodies of the Franco dictatorship. It amounted to nothing more than this but also nothing less than legally restoring the dignity that the victims had never lost - but which up till that point no administration had given them recognition for.

It is therefore possible to reuse the documentation produced by the institutions responsible for political and social repression during the Franco 
regime, for the purposes of reparations. But to do so, it is also necessary to recognise and break with the 'archival privileges' which the dictatorship applied to this documentation, especially that of courts, and which affect its identification, description, and long-term management. The example of the summary procedures is clear in this regard (Rial Quintela, 2018):

- During the war and the dictatorship, this denomination of 'summary trials' replaced the traditional 'Cases Section' (Sección de Causas) which encompassed the documentation produced by the military jurisdiction until then, in archival terms. This reflects its extension as a means of repression of the population, both military and civilian.

- From 1936 onwards, none of the documentation produced by military jurisdiction was transferred to the history archives. This remained intentionally in the custody of the military governments and the captain's general offices, exclusively at the disposal of the courts in order to monitor court cases beyond the sentence stage.

- The description tools needed to manage the enormous volume of documentation produced by the extensive structure of military justice were generally reduced to files ordered alphabetically by the names of the accused, with the topographical reference to the docket or file on the corresponding case, undoubtedly facilitating the routine management of a court, but limiting the possibilities of subsequent more in-depth historical research.

We must, then, move towards reparations as regards all these circumstances, and evaluate the possibility of giving new meaning to the part of the military justice holdings which corresponds to the period of the Civil War and the dictatorship as court holdings of the repression of the Franco regime, differentiating them from the rest of the military court holdings. It would also be necessary to ensure that the Single Transitional Provision (Disposición Transitoria Única) of the TMTs were complied with and that the custody of these court files from the period of the repression under Franco were transferred from the TMT to the general and historical archives, where they could be freely accessed without the need for authorisation from military auditors. Finally, with regard to the description, this should be extended, in those archives and by appropriate archive staff, and include all the data which could be extracted from the complete content of the documents, because this would enable a form of reparation based on the recovery of all the information on what actually occurred at that time. This goes beyond what the regime at the time wished to conceal or highlight. Thus, truth, justice, and reparations could be achieved through the application of an archive policy aimed at this objective.

The possibility that measures of this type could be applied to the rest of the military court procedures throughout the national territory would require, in addition to an indispensable political will, the extension of 
archive policies on the democratic memory, following the approach set out by the 'Basic Principles on the Role of Archivists and Records Managers in the Defence of Human Rights', a document produced by the International Council on Archives Working Group on Human Rights, ${ }^{16}$ aimed at preserving the collective memory and avoiding the emergence of revisionist and denialist theses on past historical episodes in which human rights violations were committed. However, this necessarily implies a commitment to maintain over time the human and material resources required to achieve this objective, thus reversing the permanent lack of resources, both in Spain's Defence Archives, as a whole, and in the rest of the archives of Spain's General Administration and those of other public or private bodies, because many of these may contain document collections related to human rights violations, thus guaranteeing the 'duty to preserve the memory'. This is set out in the third point of the UN High Commission for Human Rights: Updated Set of principles for the protection and promotion of human rights through action to combat impunity. ${ }^{17}$

\section{Notes}

1 Act 46/1977 of 15 October, on Amnesty (BOE-A-1977-24937).

2 Bill 22/000157 for the reform of Act 52/2007, of 26 December, by which rights are recognised and extended and measures are established in favour of those who suffered persecution or violence during the Civil War and the dictatorship, in the Boletin Oficial de las Cortes Generales (official government gazette), 190-1 of 22/12/2017, and Bill 122/000278 of Integrated Law on the Democratic Memory, and recognition of and reparations for the victims of the Franco regime and the Transition in the Boletin Oficial de las Cortes Generales, 317-1 of $15 / 10 / 2018$.

3 Order of the Ministry of Public Instruction and Health, giving instructions for the State, Provincial, and Municipal bodies, as well as those of a private nature, to provide documentary information and a bibliography of the transformation that has taken place in Spanish society as a result of current events, in accordance with the instructions inserted (BOE-B-1937-23951).

4 Order of the Ministry for the Armed Forces of 8 November 1939, creating the Military History Service (BOE-A-1939-12814).

5 A copy of this can be found in the General Military Archives of Avila: AGMAV, C. 1386,39 .

6 Royal Decree 2598/1998 of 4 December 1998, approving the Regulations on Military Archives (BOE-A-19989-29347).

7 Third Additional Provision of the RAM: 'These Regulations shall not apply to the Archives of the Military Courts and Tribunals, without prejudice to the study being undertaken to adapt the principles of these Regulations to those archives'.

8 Act 57/2007 of 26th December 2007, which recognises and extends rights and establishes measures in favour of those who suffered persecution or violence during the Civil War and the Dictatorship (BOE-A-2007-22296).

9 Royal Decree 1816/2009, of 27 November, approving the Regulations of the Military Justice Archives (BOE-A-2010-593).

10 Royal Decree 937/2003, of 18 July 2003, on the modernisation of the archives (BOE-A-2003-15237). 


\section{Henar Alonso Rodríguez}

11 Guide to Locating Legal Proceedings Initiated by Military Justice after the Civil War and during the Franco regime [Online] (Guía para la localización de Procedimientos Judiciales incoados por la Justicia Militar a raíz de la Guerra Civil y durante la etapa Franquista). Available at https://patrimoniocultural.defensa.gob. es/sites/default/files/2017-02/Gu \% C3\%ADa \%20Localisaci\% C3\%B3n \% 20 Fondos\%20Judiciales_OCT_2015.pdf, accessed 20 February 2019.

12 This interactive map is available at: https://www.defensa.gob.es/memoriahistorica/ a_militares_guia.html

13 The Historical Archive of the Spanish Air Force has two inventories on cases of Military Justice against military personnel who fought in the Republican Aviation Force during the Civil War (1936-1945), one containing court cases and the other consisting of files on purges of civilian personnel. The General and History Archives of Defence contain the list of holders of the TMT 1 files. The NorthWest Military Intermediate Archive has also published the list of holders of the cases initiated by TMT 4 in the provinces of León, Burgos, Soria, Salamanca, Zamora, Valladolid, and Álava. The inventories can be consulted in the sections corresponding to each of the archives through the web page patrimoniocultural. defensa.gob.es.

14 Autonomous Community of Catalonia Act 11/2017 of 4th July on legal reparations for the victims of Francoism (BOE-A-2017-8526).

15 Available at http://anc.gencat.cat/es/coneix/Projectes/procediments-judicials-militars/, accessed 21 February 2019.

16 Basic Principles on the Role of Archivists and Records Managers in the Defence of Human Rights, 2016, Principios básicos sobre el papel de archiveros $y$ gestores de documentos en la defensa de los derechos humanos, 2016 (online), International Council on Archives Working Group on Human Rights, Seoul, 20 February 2019.

17 Updated Set of Principles for the Protection and Promotion of Human Rights through Action to Combat Impunity, 2005 (online), Human Rights Commission (Conjunto de principios actualisado para la protección y promoción de los derechos humanos mediante la luch a contra la impunidad, 2005), E/CN.4/2005/102/ Add.1, 20 February 2019.

\section{Bibliography}

Alonso Rodríguez, Henar. 2012, "Organización de los fondos del Archivo General Militar de Ávila,” Boletín del Sistema Archivístico de la Defensa, vol. 22, pp. 3-12. Gómez Bravo, Gutmaro. 2014, Puig Antich. La transición inacabada. Madrid: Taurus.

González Quintana, Antonio. 2006, “Avatares de los fondos documentales militares y político-sociales españoles en el siglo XX," in: Los archivos españoles en el siglo XX: politicas archivísticas y producción bibliográfica. Madrid: ANABAD, pp. 118-149.

— 2007, "La política archivística del Gobierno español y la ausencia de gestión del pasado desde el comienzo de la transición," Hispania Nova: Revista de Historia Contemporánea, vol. 7, pp. 1-26 [online], accessed 10 February 2019.

Espinosa Romero, Jesús, and Rodríguez López, Sofía. 2015, “El Archivo de la Guerra Civil en Salamanca. De la Campaña a la Transición,” in: Paseo documental por el Madrid de antaño. Madrid: Universidad Complutense.

Pastor Núñez, Guillermo. 2019, "Un archivo vivo de la Guerra Civil Española," Kamchatka: Revista de análisis cultural, vol. 14, pp. 93-110, December. 
Rial Quintela, María del Carmen. 2018, "Desorientado los sumarísimos contra la mujer en la guerrilla antifranquista: aproximación a los archivos de la represión como cinta de Moebius," in: actas del II Seminario Mujeres investigadoras e investigación sobre mujeres en las Universidades Ibéricas. Salamanca, 2020 (not yet published).

- 2019, "Los fondos documentales del franquismo en los Archivos Militares," in: La alargada sombra del Franquismo. Naturaleza, mecanismos de pervivencia y huellas de la dictadura. Granada: Comares Historia, pp. 397-418. 


\title{
9 The "Centres of Remembrance" in post-communist Europe
}

\author{
José M. Faraldo
}

\section{Introduction}

For more than 40 years, the communist dictatorships of Central and Eastern Europe left a bitter memory of pain and violence. Much of this was caused by the political police agencies that made up an integral part of the system from its inception to its last days. In this chapter, we shall examine the institutions - the "Centres of Remembrance" - that have taken charge of their legacy, focusing on the countries of Central and Eastern Europe, excluding the former Soviet Union and its successor states. We shall then analyse some of the debates that have emerged in the aftermath of the fall of communism, placing these in the broader context of an assessment of the communist dictatorships of the past. Although we will mention some other cases, we shall focus specifically on three institutions that represent many other examples of national debate: the German BStU (Bundesbeauftragten für die Unterlagen des Staatssicherheitsdienstes der ehemaligen Deutschen Demokratischen Republik, Federal Commissioner for Records of the State Security Service of the former German Democratic Republic); the Polish IPN (Instytut Pamięci Narodowy, Institute for National Remembrance); and the Rumanian CNSAS (Consiliul Național Pentru Studierea Arhivelor Securității, National Council for the Study of the Archives of the Securitate).

\section{Structure and functions of the communist secret police}

The emergence of these police forces can be dated back to the very commencement of the communist regimes. ${ }^{1}$ The latter half of 1944 , for example, saw the infiltration of communists into the political police forces of the hitherto right-wing dictatorships in Bulgaria and Rumania. Although, in principle, the successor regimes were democracies and the communists were in coalition with other parties, they quickly took control of the police force - both uniformed and secret. The first months of 1945 saw the creation of the Polish secret police, in the image of the Soviet organization, as well as the emergence of a security department in the newly resuscitated Czechoslovakia, which relied on the existing organization but doubled it in 
number and would eventually supplant it. At the beginning of 1945 , even before the Soviet occupation of the country, the first communist secret services were also formed in Hungary and were later to be unified and formalised around 1950. The East German secret police, on the other hand, was only to emerge from 1950 onwards, when both German communists and the then USSR opted for the two-state solution.

The various different police forces were also to undergo various reorganizations, sometimes forming an integral part of the corresponding Ministry of the Interior (as was the norm in the Stalinist years, due to their centralising tendencies) or as independent agencies under the authority of the Ministry for the Presidency. In any case, actual control during the whole period was to belong to the central committee or politburo of each communist party. The typical duality of every true socialist state was also reflected in its secret police: on the one hand, there was the entire structure of the state which was built with an apparently democratic structure, with elections and parliaments, and on the other hand, there was the ultimate - real - power which was that of the communist party, which held the reins of power directly. One of the basic resources of this power were the secret police forces. The level of control of the Party upon these bodies increased from 1953, because the Stalinist purges of the 1930s had left the communist elites traumatised and had severely punished the party itself.

The control of police forces was generally entrusted to highly reliable party officials, with many years of militancy behind them and who were often members of the politburo, and thus part of the core of political power. Relations between the party and its respective police forces were hierarchical, with the party ensuring that the police did not accumulate too much power. These forces were subject to party orders and sometimes lacked power over their members.

The different secret police forces generally possessed a complicated, multidepartmental structure, and dealt with a number of tasks that were often far removed from each other. For example, in 1989, the East German Stasi had a department VI within its structure, whose function was to control and issue passports - similar to that of other police agencies, and which now comprises the bulk of the archival material that has been preserved. There was also a secretariat that took care of the Dynamo football club - each political police officer in the Eastern Bloc had his football team. In addition to these departments, there were other more authentically secret police departments, such as department XI (encryption), III (listening and radio counterespionage) and the " $\mathrm{M}$ " secretariat (correspondence surveillance).

The numbers of members of the secret police varied greatly over time and are not easy to define: Were the informants and moles members or not? Can a person who was registered but did not provide information be considered an informant? Many of these problems of definition have marked subsequent disputes about how to prosecute informants. In any case, by 1989 
the Securitate had about 15,000 official members and between 400,000 and 700,000 informants (for a total population of 23 million); the Stasi had 90,000 members and about 174,000 informants (population 17 million); and the Polish SB had 24,000 members and about 98,000 informants (population 37 million). ${ }^{2}$

With the fall of the regimes of state socialism in 1989, the political police were disbanded in most countries. In some cases, radically so - as in the former GDR, Czechoslovakia or the Baltic states - and in others more slowly - as in the case of Poland. In Rumania and Bulgaria, the respective police forces were to retain an enormous amount of power and would, to some extent, influence the move towards parliamentary democracy. The differences in the dissolution of the police forces would also largely determine their Aufarbeitung, i.e. the historical and political assessment of their actions and crimes. This evaluation was to be possible, thanks to the legacy that the secret police left in the form of large quantities of archive material.

\section{The archives of the secret police: the "Centres of Remembrance"}

By "Centres of Remembrance," we refer to official institutions whose mission is to preserve the archives of the police or political police under the communist dictatorships, while offering a service to those affected (the victims) and to researchers. Apart from this basic function, these "centres" are able to carry out very different tasks, depending on the legislation of each country, such as legal work (prosecution of crimes by special prosecutors) and education (propaganda and civic education on the dictatorships). ${ }^{3}$

Their special relevance and the impact of their work and holdings on the societies in question have given rise to considerable controversy and fired tough debates, influencing the consideration of history as a discipline in the countries affected by such phenomena. A fact that has had great social relevance is that all these countries possessed a wide network of informants and collaborators of the political police, who, sometimes out of conviction, sometimes for money and other times through blackmail or pressure, agreed to inform on their own relatives. ${ }^{4}$ The importance of these institutions, which are devoted to the preservation of historical sources and their scientific evaluation, among other things, is so enormous that detailed analysis may shed a great deal of light on the evaluation of the dictatorships of the past; the public use of history; the processes of transition from dictatorship to democracy; and archival organization and the social and political limits of opening up archives. In analysing the scandals as a result of the revelations of these materials, we encounter phenomena which range from the abuse of certain political powers aimed at harming opponents to the consequences which the actions of former political police and communist repression have on the societies which have emerged from dictatorships.

After the fall of the Berlin Wall, few countries allowed themselves the luxury of actively and effectively purging the former rulers. The situation was still too unstable: Soviet armies were still based in many of these countries, 
the position of the former communists was still too strong and their control of many political and economic resources was still too great. In time, however, specialised institutions would emerge which, while being custodians of the archives of the political police, undertook the job of building a general awareness of the harm done by the communist dictatorships and especially their organs of repression.

The first such centre of remembrance was the Federal Commissioner for the Records of the State Security Service of the former German Democratic Republic (BStU). The founding legend of this centre was based upon events at the demise of the dictatorship, when members of the civic movement raided various Stasi buildings to prevent the archives from being destroyed. ${ }^{5}$ This civic movement culminated in the storming and occupation of the Stasi headquarters in Berlin on 15 January 1990. This was the first - and last - freely elected parliament in the GDR that passed the law dissolving the Stasi and opening up its archives. Shortly afterwards, the GDR itself disappeared and the federal parliament of the reunified Germany passed the so-called Stasi Archives Act (StasiUnterlagen-Gesetz) on 29 December 1991, which was to lay the foundations for the development of the BStU. The situation was thus very different from that of other post-communist countries: the assessment of the dictatorship was to some extent "from outside". The fact that the new Germany had a precedent for assessing the past of the National Socialist dictatorship was not unrelated to the relatively rapid action of the state, which led to the Vergangenheitsbewältigung, the overcoming of the past, taking on a new meaning.

From the outset, the BStU consists of a central office and several regional offices. Currently, it has a budget of EUR 90.3 million and employs some 1,750 people, of whom only 12 are engaged strictly in research. The materials held by the institution stretch to some 111 kilometres, including the Stasi's own archives and the materials that had not been archived at the time of the organization's dissolution. Although there have been slight changes in legislation, the tasks entrusted to the BStU from the beginning have continued and have not changed over the years: to give every citizen access to the results of the surveillance he or she suffered from the Stasi and to allow him or her to prevent this data from being used to their detriment; to ensure the right of citizens to ascertain the extent to which the Stasi influenced and acted in public life; to ensure the use of the archives for the rehabilitation of victims and possible reparation of damages, for the prosecution of the guilty and for scientific research. The first objective mentioned - the possibility of evaluating the materials on oneself - is the one that prevails in the work of the BStU and to which all others are subordinated. It is also the objective which justifies the fact that a separate body was created and continues to be maintained, instead of handing over all these materials to the Federal Historical Archive. The BStU does not have judicial or police powers, although the publication of materials and their availability to the public may trigger the opening of proceedings or investigations by the relevant public prosecutor's offices. The commissioner's educational work is part of the powerful and well-equipped civic education machinery (Bildungspolitische Arbeit) 
typical of the Federal Republic of Germany. In this way, it is offering an invaluable service to historians and, together with the Polish IPN, is the archive most available to the public. However, especially since some court decisions at the beginning of the third millennium, its liberalisation has been interrupted and there is some difficulty in obtaining materials which have not been depersonalised (i.e. with proper names and places deleted).

Since 2018, there has been an intense debate in the press and institutions, promoted by the Commissioner himself, about the future of the BStU. Finally, the German Parliament decided in favour of absorbing the archive into the Federal Archive (Bundesarchiv), where general state documents of the GDR and its parties are held. There are dissenting voices, however, such as those of many former dissidents, who believe that this will serve to dilute investigations and hamper accessibility of the documents.

The other institute that eventually became a model in Central Europe is the Polish Institute of National Remembrance. And this is curious because Poland was one of the countries where the assessment of the past was slower at the official level, although it finally accelerated the process. As is usually the case in Poland, civil society had taken the lead, with very active associations that honoured the victims and investigated the past. Polish historiography, too, helped by a generous policy of access to party and state archives, soon achieved international status in the study of the communist dictatorship.

However, the state security archives remained closed until a much later date. A 1998 law creating the "Institute for the National Remembrance" was vetoed by the then president, the post-communist Aleksander Kwaśniewski, on legalistic grounds. This institute was to house the archives of the political police and be responsible for issuing certificates of noncooperation with the repressive forces as an agent or informant (the socalled lustration process). Of course, this would have meant the end of the political career of many ex-communists. The debate was fairly heated, and it was not until 2000 that the Institute was able to begin its work. The social relevance of the IPN came with the change of government in 2006, when Jarosław Kaczyński and his Law and Justice party came to power. The IPN then became an armed wing of the attempt at rapid de-communisation promoted by this party. The files of alleged collaborators with the political police in communist times came to light at the most profitable time for the new power and were used as a way of fighting its political opponents through a smear campaign. The opening up of the archives to unscrupulous journalists and the "leaks" to like-minded press made the institute the centre of a violent and bitter debate for two years, which divided Polish society and only abated when, in the early elections of 2008, Kaczyński lost power. In part, however, because of the politics of placing trusted people in key positions in the IPN - including the director himself - the institute remained highly politicised, becoming a bastion of national-conservative opposition to the ruling National Liberals. 
This situation took a turn for the worse when, in 2015, the Law and Justice party won the elections again. In a period of just over two years, the Institute lost many of its most progressive researchers and dozens of nationalists were hired. The statutes were also changed, as was the way the president of the Institute was elected, to make it more easily controllable.

The importance of the lustration process and the construction of a new policy on the country's history explains the surprising size and multiplicity of the institute's tasks. The IPN's budget in 2009 was around 50 million euros but by 2018 it had reached 85 million (with a certain drop from the previous year). A total of 2,145 people worked at the institute in $2009,13 \%$ of whom were researchers, and the number increased over the years. This has made it the best-funded historiographic research centre in the country. The historians of this institute have done an incredible amount of research in recent years. Several hundred books have been published, dozens of conferences have been organised and many exhibitions have been run. There is no institution in Eastern Europe that has played a more active role in promoting contemporary history than the IPN, although, as we have seen, its political manipulation has been very clear from the outset.

The IPN preserves over 86 kilometres of archives, 35\% of which are located at its headquarters in Warsaw. There is also a network of 11 regional offices with an educational, scientific and legal role. The institute - unlike the BStU - is also home to a special prosecutor's office, which in 2008 had 139 prosecutors devoted to prosecuting crimes "against the Polish nation" since 1939. As, unlike the BStU, the IPN is not only responsible for prosecuting the crimes of the communist era, it also investigates the era of the German and Soviet occupations between 1939 and 1945. One of its first challenges, right at the outset, was to carry out an in-depth investigation of the pogrom against the Jewish population in the town of Jedwabne, carried out by its Polish neighbours in 1941. This investigation was considered necessary following the scandal raised by the book Neighbours by the Polish historian of Jewish origin, and nationalised American, Jan Tomasz Gross (Machcewicz and Persak 2002). We thus see how occupations and dictatorial regimes that followed one another left traces that, in the end, became linked to the problems of the dictatorships that followed them.

In Rumania, it was not until 1999 that a law made it possible for victims of the regime to view their files. The fact that the political police of the Ceausescu regime have continued to this day has, however, prevented any real discussion over the past. The debates have been very intense, due also, let us not forget, to the fact that Rumania was the only country to emerge from communism through a violent revolution in which at least 1,104 people died and thousands were injured.

Act 187/1999, which regulated the "lustration" or monitoring of public employees, also set up the CNSAS, the National Council for the Study of the Securitate Archives. However, the following year the post-communists won the elections and until 2005 the CNSAS was nothing more than an archive devoid of material (November 2005, 9,142 files). With the change 
of government in 2004, when the conservatives came to power and the populist, Traian Basescu, was elected president, the situation changed radically: in December 2005, there was a massive transfer of archives from the Rumanian secret service to the CNSAS (1,555,905 files, comprising 1,894,076 case files). A decision by the constitutional court, however, led to Law $187 / 199$ being declared unconstitutional and a paralysis in the progress of the institute that was not remedied until 2008, when a new and much more expansive ordinance made possible a sort of overhaul of the CNSAS.

As of 2010, with the new director, Dragoş Petrescu, archives began to be opened up and the institute has been brought into line with the now customary standards of other institutes. The CNSAS archive, in comparison with the others, is the one that has most probably lost more records, due to the intentional destruction by former members of the secret police. Thanks to the organizational continuity of the secret police, this organization has had more than 15 years to destroy these records. The archive contains some two million files, although almost half of them are also on microfilm. The budget of the CNSAS has been increasing since 2004, and in recent years it has been estimated at three to four million euros. A comparison with the other two institutes presented here illustrates the practical difficulties faced by the CNSAS.

Czechoslovakia carried out a very rapid purge of former communists, which initially proved to be a model for the region. As early as 1989, the Minister of the Interior prohibited members of the political police from taking any action and eventually disbanded the force. An October 1991 law forced a large number of officials and those working for the state to obtain a certification that they had not been informants for the secret police. A special agency was created for this purpose, under the Ministry of the Interior: the Department for the Documentation and Prosecution of communist Crimes. The action of this department was basically official, and it did not allow access to the archives, although, in theory, these were also mostly open from the 26 April 1996 Act onwards. Compared to the GDR or Poland, Czech historians appear to be in less of a hurry to review the communist dictatorship. With the exception of some areas, research has been rather slow. An exception to this is the work of the Institute of Contemporary History at the University of Prague, where a sizeable group of young historians is doing excellent work.

It is precisely this lack of a significant echo from the first purge, together with the example of the neighbouring countries, that led the Czech parliament to create the "Institute for the study of Totalitarian Regimes" (Ustaz pro studium totalitnich režimü) and the State Security Archive, in May 2007. As we can see, the Czech case is somewhat different: the punitive function has been kept completely separate, as has the archive itself. The Ustav is above all a research institute, which seeks to clarify recent history - including the period of Nazi occupation from 1938 - and which also has a teaching role and one of civic education. 
We have mentioned Czechoslovakia, however we should qualify this. The 1991 law was also valid in Slovakia, but post-communist Slovak politicians did not apply it. When, in 1994, the Czechoslovak state was divided into two independent states, the law ceased to be binding (in 1996, to be precise). It was not until 1998, when Vladimir Meciar's authoritarian government fell, that the real clean-up process began. In 2002, a law was passed which gave access to the archives of the political police and an "Institute for the Memory of the People" (Ústav Pamäti Národa) was created, as in the Czech Republic, to investigate not only the crimes of communism but also those carried out between 1939 and 1945 in the fascist Slovak state. However, unlike in the Czech Republic, the law did not remove from their posts those who collaborated with state security, although a certain social pressure has been felt in cases which became known, forcing some of the accused to resign. The Institute for the Memory of the People has also made use of efficient means such as publishing the lists of those figuring in secret police records as collaborators, on the Internet. This gave rise to major controversy, because these lists did not differentiate between volunteer col laborators and citizens who had been used to obtain information, unbeknown to them.

In Hungary, there was an early attempt at a purge; however, the victory of the post-communists did not allow archives to be opened up until 1994 and even then, very slowly. It was only after 2003 when, following a scandal caused by the discovery that the Prime Minister had been an informant, the "Historical Archive of the Hungarian Secret Services" (Állambiztonsági Szolgálatok Történeti Levéltára, ÁBTL) was created, which is similar to the centres of remembrance analysed here.

In Bulgaria, there were several attempts to open up police files, but it was not until 1997 that the relevant law was passed, also opening the way for testing among civil servants to ascertain whether or not they had been informants for the secret services. However, in 2002, with the law on state secrets, the archives were closed again. Simeon of Bulgaria and his "national movement" were in favour of keeping the archives closed; however, a change in the balance of power led to the adoption of a new law in 2006 and the creation of the "Committee for the opening of documents and the membership of Bulgarian citizens in state security and the intelligence services of the Bulgarian People's Army". Despite its extremely bureaucratic name, this committee is, in essence, a replica - adapted to the idiosyncrasies of Bulgarian society - of the Central European centres of remembrance.

Little by little, through joint committees, publications and a large number of international seminars and conferences - in which the Polish IPN has been a pioneer - the centres of remembrance have created a working style and a structure of international collaboration which already makes it possible to speak of an established model to assess the past and historical research on the material held by the political police. 


\section{José M. Faraldo}

\section{Use and abuse of the secret police archives}

In July 2010, the Czech historian Jiři Suk said in an interview that the "agentmania" - as he called it - and the hunt for informants led by the media after the fall of communism had been a mistake. In his opinion, the politicised use of public exposure of those who had collaborated with the secret police had done more harm than good to post-communist society. It is true that from the very moment state socialist systems began to fall, the secret police were in the line of fire. Very soon the fear spread that those who had repressed and exercised their power against citizens might continue to do so, from the privileged positions they had access to, thanks to their position in the fallen regime. That explains why, in many of these societies, there was a constant clamour for a lustration of public life.

When, in 1990, West Germany absorbed the German Democratic Republic, the latter was quickly and expeditiously purged of its communist officials. It is true that this move, which occurred at all levels and in circles such as the university, caused most of the teaching staff to lose their posts, leading to protests from East German society itself (Schultz, 2000, pp. 303-324). Former GDR citizens complained that this was nothing more than the desire to "place" unemployed Western academics and officials, which, empirically, appears to be quite true. This led to the reviled ex-communist party taking strong root and surviving the debacle to become one of the main political organizations in the East (Martín de la Guardia, 2005, pp. 285-308). The case of the GDR is also the most extreme as regards opening up archives: the $\mathrm{BStU}$ contains all the documents kept by the Stasi and these are available to any researcher, as well as to any person concerned. Those affected have also received certain financial reparations, based on the model of compensation for the victims of Nazism. However, like the latter case, compensation has tended to be small and difficult to obtain. In reunified Germany, the most intense debates have also taken place around the so-called Ostalgie, that is, the nostalgic and sometimes benevolent reminiscence of the times lived under the communist dictatorship.

The BStU archives have been the subject of harsh criticism from the outset, and although the debate over their closure and the transfer of their materials to the federal archives flares up from time to time, the continuity of the institute seems assured. From the beginning, the great controversies that have arisen from the archives have been caused by various types of discoveries of sources. On the one hand, the fact that East German politicians, such as Gregor Gysi or Manfred Stolpe, may have been collaborators of the Stasi is repeated in almost every election campaign. This has sometimes led to resignations, but in general, society in the "new Länder" (the former GDR) does not seem to have been very affected by these revelations.

On the other hand, and here the scandals have been greater, more and more information has been revealed about the way in which the Stasi infiltrated the Federal Republic of Germany (Amos, 1999). ${ }^{6}$ Let us not forget 
that as early as 1974, Chancellor Willy Brandt had been forced to resign when it became known that one of his closest collaborators was a Stasi agent. With access to the archives, the accusations - and proven data - have multiplied. Magazines such as Konkret, political parties and associations (both left and right) were financed by East Germany; politicians, police officers and businessmen from all over West Germany had been Stasi informants. In May 2009, a scandal arose at the discovery that Karl-Heinz Kurras, the policeman who murdered the protester Benno Ohnesorg in 1967, had been a Stasi agent. With Ohnesorg's murder began the radicalisation of the German student movement, and the participation of the Stasi in this through Kurras - was certainly frightening (Kellerhoff, 2010). The thesis of the "Infiltrated Republic" stands at the centre of a bitter debate that has been going on for two decades.

Nor has the debate over the Polish IPN been any less heated, mainly because of its political exploitation. Part of the task entrusted to the institute has been a broad campaign to recover positive aspects of recent Polish history, such as remembering the many Poles who helped Jews during World War II or building a memory of Polish dissidents from the communist period. Much of the IPN's action has been directed at recovering the memory of the anti-communist partisans of the immediate post-war period and promoting the heroes of the resistance. This has sometimes involved conflict, as some of those who resisted were, at the same time, rampant anti-Semites or xenophobes. One example is Józef Kuraś Ogień, an anticommunist partisan, leader of a guerrilla group, who has been accused of anti-Semitic and anti-minority crimes. Thus, while the Polish institute published a hagiographic work on him and paid tribute to him, its Slovak equivalent, the UPN, opened an investigation into Kuraśs crimes against the Slovak minority. ${ }^{7}$

Another interesting case of the use of the institute's power to defend Poland's image is the publication of a book by a Polish American researcher, Marek Jan Chodakiewicz, on the Polish-Jewish conflicts. In his book, Chodakiewicz, who takes an extreme right-wing position, presents a defence of Poland, attempting to free the country from accusations of anti-Semitism by the method of defining the "guilt" of the Jews themselves in the pogroms carried out in the country after the Holocaust. To do this, he uses the techniques of the now classic right-wing revisionism. Interestingly, this book was hastily published by the IPN, just a few weeks before the translation of the book by the American historian of Jewish-Polish origin, Jan Tomasz Gross, appeared in Poland. His book, Fear, an intense but somewhat exaggerated analysis of Polish anti-Semitism, had already caused a certain stir in its English version. With the publication of Chodakiewicz's book, the IPN leaders obviously intended to neutralise the consequences of Gross's work (who, as we have seen, had already created controversy with "Neighbours" earlier). 


\section{José M. Faraldo}

Apart from rebuilding a positive image of Poland, the other pillar of the institute's strategy has been a fierce attack on communism and an attempt to symbolically delegitimise the regime. One of its actions, accepted by the Polish parliament, was the proposal to withdraw special war pensions from the Poles in the international brigades that fought in the Spanish civil war. This led to brief diplomatic tension between Spain and Poland. The Spanish Senate unanimously voted for a petition to Prime Minister Zapatero to act to prevent this. ${ }^{8}$

Slovakia is another good example of the political use of archival policies; accusations against political enemies based on files obtained by obscure means; and of accusations of alleged collaboration with Soviet or local secret services. A good example is the famous press conference held by Vladimir Meciar - the then head of the Slovak government - accusing an opponent of being an informer on the basis of the information contained in the file held by the political police. When asked by journalists where he had got the file, Meciar replied that "he had found it that morning on his desk", a phrase that in Slovakia has come to mean something that has been achieved by illegal means (Bukalska and Tekieli, 2005, p. 12).

One of the main problems with the existence of these files is the ease with which personal data has been leaked to the media. This has sometimes led to what has been called "wild lustration", i.e. problems of all kinds and accusations against people whose names have come to light. In 1992, a former Czech dissident, Petr Cibulka, published a list of 220,000 names of people he accused of collaborating as informants with the communist police. Over the years, an official commission recognised only a proportion of these as informants, because the "Cibulka List" (as it was called) also included many who were cited in police documents as "possible targets" but against whom there was no evidence. In the same year, a list of a few dozen names drawn up by the far-right Polish Minister of the Interior, Antoni Macierewicz, caused a scandal that brought down the entire government. The minister, in all probability, used his prerogative to denounce political opponents, including the President himself of the time, Lech Wałęsa, the veteran opponent and Nobel Peace Prize winner. Ten years later, in late 2004, a right-wing Polish journalist and former dissident, Bronisław Wildstein, stole a copy of the list of state security files from the IPN and publicised it over the Internet. It was not possible to know from this who, in the list, were the informants, who were the agents or the victims, so the damage caused to the reputation of many innocent people was quite serious.

Another example is the case of Milan Kundera. The famous Czech anti-communist writer and dissident who in 2008 was accused of having denounced a person during his youth who consequently received a harsh sentence and spent 14 years in prison. A historian at the Institute for the Study of Totalitarian Regimes discovered the document. The document was published in the journal Respekt and caused a serious scandal, while suddenly placing a Centre of Remembrance that had been operating for only a 
short time in the limelight. This story also shows us how the desire of young historians to create a public profile for themselves, and of the research institutes themselves to attract attention, may have led to the search for documents and exposure of famous people, in an attitude that has little to do with purely scientific aspects (Blaive, 2009, pp. 203-225).

In general, in all these countries, the rise to power of populist parties or personalities at different times over the last 20 years has created an atmosphere in which everyone was guilty until proven otherwise, and sometimes even then. Indeed, many former politicians, dissenters or intellectuals are still under suspicion because, it is claimed, even where there are no documents to identify the collaboration of these persons with the police, this is due to the disappearance of these documents from the archives, for obscure reasons and at the hands of unidentified agents.

\section{Conclusions}

The importance that the former communist secret services continue to possess in the lives of post-dictatorial Central European societies is not reduced to the very persistence of their staff and their structures, which have generally been greatly exaggerated. The legacy of the secret police covers a wide area that ranges from the symbolic to the political, and which makes it very difficult to overcome the bitterness and resentments produced by the repressive action of the organs of these dictatorships. The supporters of opening up the archives were in the habit of pointing out that the exposure of agents and clarity over the political police would bring much-desired national concord, in a kind of catharsis produced by the truth. This has not been the case, however. In all countries, including Federal Germany, state security files have given rise to controversy and, indeed, continue to stoke the fire of paranoia, ignited, above all, by the mass media.

The scale of these problems largely depends on the degree of politicisation and manipulation that surrounds the archives and centres of remembrance. Politics has found a way to return to historiography, very differently from the communist era, but no less effective. The concept of "historical memory" has been used - and abused - to try to build monopolies of meaning no less than those of the communism of yesteryear, now, to a large extent, projected against it and its memory.

On the other hand, it is true that free access to the archives and a scientific investigation that will necessarily be forced to gradually renounce the vengeful urgency of affected generations will in the long run clarify the role of the police in the repression, debunking some myths and reaching some degree of consensus. As witnesses of the time emerge from the public scene, historians should be able to make use of archive material without so much pressure, thus taking advantage of incredibly rich sources to reconstruct a past that is not only that of moral defeats, hidden betrayals and the miseries imposed by an oppressive state. 


\section{Notes}

1 On these police forces, a general comparative summary: José M. Faraldo, Las redes del terror. Las policías secretas comunistas y su legado, Barcelona: Galaxia Gutenberg 2018. A re-edited and revised manual: Persak, Krzysztof, and Kamiński, Łukasz. 2005, A Handbook of the Communist Security Apparatus in East Central Europe, 1944-1989. Warsaw: IPN; Persak, Krzysztof, Kamiński, Łukasz, and Gieseke, Jens, eds. 2009, Handbuch der kommunistischen Geheimdienste in Osteuropa 1944-1991. Gotinga: V\&R; Persak, Krzysztof, and Kamiński, Łukasz, eds. 2010, Czekiści. Organy bezpieczeństwa w europejskich krajach bloku sowieckiego 1944-1989. Warsaw: IPN; National Summaries: Gieseke, Jens. 2001, Mielke-Konzern: Die Geschichte der Stasi 1945-1990. Stuttgart and Munich: Deutsche Verlagsanstalt (there is a second revised edition); for Poland: Terlecki, Ryszard, Miecz i tarcza komunizmu: historia aparatu bezpieczeństwa $w$ Polsce 1944-1990. Kraków: Wydawnictwo Literackie; for Rumania: Deletant, Dennis. 1995, Ceausescu and the Securitate: Coercion and Dissent in Romania, 1965-89. London: Hurst \& Co. and New York: M.E. Sharpe; Oprea, Marius. 2008, Bastionul cruzimii: o istorie a Securității (19481964). Bucharest: Polirom. A comparative analysis: van de Grift, Liesbeth. 2012, Securing the Communist State: The Reconstruction of Coercive Institutions in the Soviet Zone of Germany and Romania, 1944-1948. Lanham, MD: Lexington Books.

2 Figures in: Persak, Czekiści; Stan, Prezentul.

3 See the foundational charter of the "European Network of Institutions entrusted with the Archives of the Secret Police" 2010 in: Das "Europäische Netzwerk der für die Geheimpolizeiakten zuständigen Behörden” Ein Reader über die gesetzlichen Grundlagen, Strukturen und Aufgaben europäischer Aufarbeitungsbehörde. Berlin: BStU, p. 84.

4 On police informants: Albu, Mihai. 2008, Informatorul: Studiu asupra colaborarii cu Securitatea. Bucharest: Polirom; On the actual dossiers and reports: Krone, Tina, Kukurtz, Irena, and Leide, Henry. 1992, Wenn wir unsere Akten lesen - Handbuch zum Umgang mit den Stasi - akten, Berlin: BasisDruck; Graczyk, Ryszard.2007, Tropem SB:Jak czytaćteczki. Kraków: IPN; Chivu-Duta, Carmen and Albu, Mihai. 2007, Dosarele Securitatii: Studii de caz, Bucharest. Available at https://www.worldcat.org/title/dosarele-securitatii-studii-de-caz/ oclc/895533761.

5 Even though it is possible that a proportion of these protesters were "unofficial informants" of the Stasi who wanted to erase the traces of their collaboration with the regime. This fact, of course, does not imply that it changes the general view of what occurred as a citizen reaction.

6 With a sensationalist and vindictive tone, but good data: Knabe, Hubertus. 1999. Die unterwanderte Republik: Stasi im Westen. Berlin: Propyläen Verlag.

7 “Słowacki IPN 'prześwietli' polskiego partyzanta," Gazeta Wyborcza, 20 December 2008.

8 "El Senado defiende a los brigadistas comunistas polacos repudiados en su país," El País, 23 March 2007. For the debate, see: Faraldo, Jose M. 2007, "Rozmówki hiszpańsko-polskie," Polityka, 23 June, pp. 52-55.

\section{Bibliography}

Albu, Mihai. 2008, Informatorul: Studiu asupra colaborarii cu Securitatea. Bucharest: Polirom. 
Amos, Heike. 1999, Die Westpolitik der SED 1948/49-1961: "Arbeit nach Westdeutschland" durch die Nationale Front, das Ministerium für Auswärtige Angelegenheiten und das Ministerium für Staatssicherheit. Berlin: Akademie Verlag.

Blaive, Muriel. 2009, "L'ouverture des archives d'une police politique communiste: le cas tchèque, de Zdena Salivarová à Milan Kundera,” in: Combe, Sonia (ed.), Archives et histoire dans le sociétés post-communistes. Paris: Éditions La Découverte.

Bukalska, P., and Tekieli, S., eds. 2005, Problem lustracji $w$ Europie Środkowej $i$ krajach battyckich. Warsaw: Ośrodka Studiów Wschodnich.

Deletant, Dennis. 1995, Ceausescu and the Securitate: Coercion and Dissent in Romania, 1965-89. Londres: Hurst \& Co. and New York: M. E. Sharpe.

Faraldo, Jose M. 2007, “Rozmówki hiszpańsko-polskie,” Polityka, 23 June.

- 2018, Las redes del terror: Las policías secretas comunistas y su legado. Barcelona: Galaxia Gutenberg.

Gieseke, Jens. 2001, Mielke-Konzern: Die Geschichte der Stasi 1945-1990. Stuttgart and Munich: Deutsche Verlagsanstalt.

Kellerhoff, Sven Felix. 2010, Die Stasi und der Westen: Der Fall Kurras. Hamburg: Hoffmann und Campe.

Knabe, Hubertus. 1999, Die unterwanderte Republik: Stasi im Westen. Berlin: Propyläen Verlag.

Krone, Tina, Kukurtz, Irena, and Leide, Henry. 1992, Wenn wir unsere Akten lesen - Handbuch zum Umgang mit den Stasi-akten. Berlín: BasisDruck.

Machcewicz, Paweł, and Krzysztof, Persak. 2002, Wokół Jedwabnego, 2 vols. Warsaw: IPN.

Martín de la Guardia, Ricardo. 2005, "Los orígenes del Partido del Socialismo Democrático (1989-1993): el Ave Fénix roja en Alemania," Ayer, vol. 60, ISSN:1134-2277.

Niezabitowska, Małgorzata. 2007, Prawdy jak chleba. Warsaw: Prószyński.

Oprea, Marius M. 2008, Bastionul cruzimii: o istorie a Securității (1948-1964). Bucharest: Polirom.

Persak, Krzysztof, and Łukasz, Kamiński. 2005, A Handbook of the Communist Security Apparatus in East Central Europe: 1944-1989. Warsaw: IPN.

Salivarová-Škvorecká, Zdena, ed. 2000, Osočení. Pravdivé př́běhy lidíz 'Cibulkova seznamu'. Brno: Host.

Schultz, Helga. 2000, "La nación tras el diluvio: una perspectiva germanooriental," Cuadernos de historia contemporánea, vol. 22.

Stan, Lavinia, coord. 2010, Prezentul trecului recent: Lustratie si decomunizare in postcomunism. Bucharest: Editura Curtea Veche.

Terlecki, Ryszard. 2009, Miecz i tarcza komunizmu: historia aparatu bezpieczeństwa $w$ Polsce 1944-1990. Cracovia: Wydawnictwo Literackie.

van de Grift, Liesbeth. 2012, Securing the Communist State: The Reconstruction of Coercive Institutions in the Soviet Zone of Germany and Romania, 1944-1948. Lanham, MD: Lexington Books. 


\title{
10 A legacy of the DDR

\author{
The Stasi Records Archive
}

\author{
Dagmar Hovestädt
}

\section{Introduction}

"The open records are a gift of the revolution". ${ }^{1}$ This headline is a fitting shorthand for what is at the core of the Stasi Records Archive's power. It describes its historic origin as well as the responsibility deriving from it while identifying the yet untested idea at the core: never before had the opening of all records of a state intelligence body in order to address the wrongs of the past been attempted. It took the people of East Germany and their uprising against one-party rule in 1989 to make this possible. As a result, the united Germany for 30 years has used these records in numerous ways to address issues of transitional justice, history, remembrance, and also contemporary conflicts, rendering the records an established part of the memory of the nation.

In this case study, the archive's story will be told through the three historic phases that determined its course. First, the records will be put in the context of their origin in order to understand the specific nature of the information they contain and their potential. Second, the circumstances will be described which transferred control over these records to the people and what they hoped to achieve in a process that ended with the institution of a Commissioner as custodian on the day of German unification. And third, this chapter will address the way access to the Stasi records was organized and what effect it had in addressing the injustices committed under the SED dictatorship. It will end with a perspective on the future of the records.

\section{A people under suspicion: records of repression}

In order to better understand the content of the archive and its potential, it is helpful to briefly retrace the history that led to its creation. As Eastern Europe after World War II quickly became a consolidated bloc of communist states under Soviet control, the prospect of democracy and universal access to human rights, a then nascent idea, disappeared from the political agenda. One-party rule was established throughout Eastern Europe, leaving no room for civic society and fulfillment of rights. The historian Anne 
Applebaum analyses in her three-country study "Iron Curtain" in great detail how quickly the Soviet Union was able to turn the post-war societies of Central Europe into one-party-ruled communist states within its sphere of influence. "The speed with which this transformation took place was, in retrospect, nothing short of astonishing. In the Soviet Union itself the erection of a totalitarian state had taken two decades, and it had proceeded in fits and starts". ${ }^{2}$

East Germany was founded as a state on October 7, 1949. By then the Soviet-backed Socialist Unity Party (SED) of East Germany was already in control of power by manipulating the election process in East Germany. To consolidate its reign, the SED sought to establish control over all sectors of society and continuously protect it. ${ }^{3}$ One of the central tools of the communist party's maintenance of power was the use of secret police organizations. In East Germany, the Ministry for State Security (MfS) was founded in February 1950, under strict supervision by thousands of Soviet operatives on the ground. ${ }^{4}$ From its inception, it considered itself the "shield and sword" of the communist party. The mindset of the officers of the MfS was steeped in the ideology of service to the SED and the protection of the "communist revolution" from all "enemies" under all circumstances. This mentality determines the logic of the work of the MfS, and the records reflect this logic and psychology.

For 40 years, the Ministry for State Security, widely known by its German acronym Stasi, set out to protect the party's hold on power by treating its own people as the central most dangerous source of instability. As long as people were adhering to the demands of the communist party and fulfilled their socialist duties as laid out from kindergarten to workplace, no trouble followed. But expressions of dissent - from adhering to a religious faith to refusing military education at school, from listening to Western music to reading books critical of the regime - would almost always land you in the sights of the Stasi.

The Stasi's core mission was to gather information as precautionary strategy. Once "political-ideological diversion" ${ }^{5}$ was detected, the Stasi became active against those citizens in order to prevent any activity from growing into a problem for the party's hold on power. When in June 1953 an uprising against the party mobilized over one million people all over East Germany, an existential crisis of the young SED state had come about. Worse, it had caught the emerging Ministry for State Security off-guard. Only with the help of Soviet tanks was the SED able to squash the "Volksaufstand", the people's uprising. The SED saw the uprising as a failure of control and blamed the Stasi. ${ }^{6}$ The secret police was from then on under pressure to prove that it was able to foresee any such movement - an enormous task. Forms of dissent could be manifold throughout society and untold numbers of people could be defined as "enemies" of the party. It became the Stasi's prime objective to have eyes and ears everywhere in society or at least to maintain the aura of such omnipotence. One of its central tools in 
this endeavor was the use of regular citizens as informants. In 1989, about 180,000 of these "unofficial collaborators", as they were called in the Stasi bureaucracy, were registered in the files as active. The ministry itself had 91,000 official employees. In relation to the East German population of 16 million inhabitants, the Stasi was the largest secret police apparatus in Eastern Europe during the Cold War.

\section{A people's uprising: the records and the revolution}

In East Germany, after the fall of the Berlin Wall on November 9, 1989, the citizens soon found an urgent call to action. The Stasi had begun to destroy documents which prompted East Germans, beginning on December 4, 1989, to occupy the buildings of the Stasi all over the East in order to stop the destruction of the files. ${ }^{7}$ Those activists saw these documents as evidence of human rights violations, needed for future discourse over this period. When on January 15, 1990, citizens also invaded the premises of the Stasi headquarters in Berlin, the power of the dreaded secret police had finally been broken. ${ }^{8}$ Their records however were preserved and in the hands of the people. They now had to decide what to do with a body of documentation that had been under the administration for 40 years of one ministry which had carefully preserved the whole archive.

Citizens' committees formed to determine how to handle the records. "To each their own file" had been an often-heard demand during the demonstrations. After 40 years of being spied upon and living under the rule of the party, people wanted access to the files. As the first Commissioner for the Stasi Records Joachim Gauck observed, they demanded to regain control over the information to "free themselves". ${ }^{9}$ Despite an intense debate about the pros and cons of opening these records in the crumbling East Germany, the demand by the people who had just toppled a regime in a peaceful revolution - to open the Stasi records - became impossible to deny in the ensuing process of German unification. Even additional skeptical voices from the West could not stop the momentum. ${ }^{10}$ The saved records were made accessible for the people and the archive opened on the day of German unification.

The process that led to the idea of opening the archive was a natural outcome of the developments in the Peaceful Revolution and a logical consequence of the engagement of the newly empowered citizenry. The tables had turned, the power over the information now belonged to the people, and they wanted access, a demand they carried over into the unification process. ${ }^{11}$ They had not necessarily conceived of access to the Stasi records as an essential part of the transition, as unification had not been foremost on their minds. But as the vast majority of transitional justice processes rely on archives, ${ }^{12}$ the "open records" also became a central ingredient of the German transition process. 
There were two additional uniquely German factors that contributed to the decision-making process to open the archive immediately after the regime change. First, the previous reckoning with another dictatorship, the Nazi regime, was a decisive factor, especially on the West German side which held more political power over the unification process. Coming to terms with the holocaust and the war crimes of World War II as the perpetrator nation had been a slowly evolving process that over time developed into a sustained and concrete effort. ${ }^{13}$

National Socialist crimes and their victims are an integral part of collective memory and Germany's political identity. That German society was able to shift from suppression and silence to an active engagement with crimes and guilt is often considered a central factor in its democratization. ${ }^{14}$

It was exactly this decades-long struggle with the murderous and monstrous past that set the stage for addressing the "other" German dictatorship of the 20th century right away. Addressing the Nazi past had strengthened democracy, but it had taken a long time. As a consequence, in 1990 the Germans in the process of unification were willing to embrace instant measures of actively addressing the communist repressive regime. Coupled with the ideas and standing of the East German dissidents and citizens who actively had freed themselves from that regime, opening the records right away became an accepted idea.

A second historic factor unique to the German case made the decision of an instant opening much easier to implement. The political elites who had benefited from the Stasi, no longer had any access to power. The disappearance of the state responsible for the injustices into a united Germany was also a central factor enabling the opening of the archive soon after the repressive regime ended. With the former East German state nonexistent, the need to use the documentation of the Stasi for an intelligence body in a new era was also eliminated, in fact it was as good as forbidden. ${ }^{15}$ The archive was opened on Day One of the reunited Germany on October 3, 1990, while other Eastern European countries started this process as much as 15 years later. ${ }^{16}$

\section{A people coming to terms: the records and the reappraisal of the past}

It took the united parliament, the "Deutsche Bundestag" just over a year to formulate the Stasi Records Act (StUG). With its enactment on December 29, 1991, the "Federal Commissioner for the Records of the State Security Service of the former German Democratic Republic", in short Federal Commissioner for the Stasi Records or BStU, began its work. The Commissioner was voted into office directly by the Bundestag for a term of five years that could be extended for another five years. ${ }^{17}$ This particular arrangement - a 


\section{Dagmar Hovestädt}

person chosen by the Bundestag to head the archive on the basis of their biography and critical distance from the East German dictatorship - felt necessary at the time. It was meant to ensure an impartial, trustworthy, and rule-based access to the records, whose usability for political purposes had been proven in the last months of East Germany..$^{18}$ Giving the job to a highly trustworthy individual mandated with a direct vote of confidence by parliament was meant to remedy any potential for abuse. The commissioner is independent in his exercise of office and bound by the rules set forth in the Stasi Records Act. ${ }^{19}$

The StUG has at its core the difficult task of balancing two opposing legal concepts. It requires transparency of government action while maintaining the privacy of those subjected to this action. The Act intends to "facilitate individual access to personal data pertaining to oneself which the State Security Service has stored so that the individual can clarify what influence the State Security Service has had on his personal destiny". ${ }^{20}$ While it enables access for individuals to their own data, the BStU is tasked to protect this data from public access. In a partial reversal of the data protection idea and to support transparency, the StUG makes records available for researchers and journalists for the purpose of enriching the public's understanding of the power mechanisms of the SED dictatorship. Government action (by both the Stasi and the Communist Party) is meant to be rendered transparent and thus deprived of its secrecy. The StUG permits the leaving open of names of those working officially or unofficially for the Stasi when the documents are given to researchers or journalists, who in turn through their publications make those names widely known. This transparency is intended to foster public debate about the reappraisal of the past and the mechanisms of repression. In files given to researchers and journalists, information relating to subjects of Stasi activity ${ }^{21}$ is redacted, unless the persons concerned have given permission. Access to the names of those acting on behalf of the state is believed essential for a concrete discussion of injustices and for a chance to come to terms with each concrete action within the dictatorial system of East Germany.22

Access to the records is, furthermore - defined as a third purpose in the Stasi Records Act - also allowed for both public and non-public institutions. In this process, names will be made known in a semi-public sphere. Agencies asking for information will be directly provided with information by the $\mathrm{BStU}$ on persons who are documented in the Stasi files. Publication of that information is in the hands of the asking party. Here the StUG allows for several sub-purposes. One is the vetting of people in public office or public administration to expose past activity as "unofficial collaborators". Many public agencies request access also to further rehabilitation or reparations proceedings for victims of the Stasi, to clarify retirement issues or to support criminal investigations of SED and Stasi crimes. ${ }^{23}$

Lastly, the agency of the Federal Commissioner for the Stasi Records itself is tasked with contributing to the reappraisal of the SED dictatorship. Its job 
is the "analysis of the activity of the State Security Service through instruction of the public on structure, methods and mode of operation of the State Security Service". ${ }^{24}$ For this purpose, the Federal Commissioner established a research and education department in 1992. Numerous scientific and general audience publications, exhibitions, school materials, and increasingly, digital and online activities have been produced to bring the archive to life and to further discussions about the effects of the Stasi.

By the beginning of 2020, the agency has counted a total of 7.3 million requests for access, among them over 3 million requests by individuals, about 1 million of them as repeated requests for more information. With about 111 kilometers of documents, over 2 million uncontextualized photographs and manifold photos within the files, 30,000 audio files, films, and videos, and around 100 data projects, the Stasi Records Archive ${ }^{25}$ is one of the largest archives in Germany. The BStU has a central location in Berlin and 12 outlying archives in Eastern cities where the Stasi used to have district administration offices.

The perception of the large set of measures that were implemented to address the injustices of the communist past was skewed through a complicated East-West lens. The narrative of how to deal with the East German past was partly overshadowed by the West German way of dealing with the Nazi past, while at the same time Western Germans also relished ideas of having been victorious over the Soviet empire:

No other state so directly addressed Cold War narratives of victory while simultaneously working through a totalitarian past. Following unification, the workings of the GDR regime were interrogated through legal trials of leaders and border police, and federal investigative commissions, a process based in part on Germany's experience dealing with the National Socialist past (Deutscher Bundestag, 1994). ${ }^{26}$

In this complicated landscape of two consecutive but very different German dictatorships and the disappearance of one German state through unification lies the unique character of the German case. As many historians have noticed about the ongoing process of unification, "narratives of the Cold War also continue to differ between Western triumphalism and Eastern defensiveness". ${ }^{27}$ The Stasi records permeated the many transitional justice processes as they were an ample, alluring, and - by the nature of the all-encompassing information they contained indispensable resource. As a consequence, the Stasi in the 1990s dominated the dialogue of reappraisal of the East German dictatorship, with unintended consequences.

In the same measure as the reappraisal of the past in the united Germany seemed to be condensed to "Stasi" and "rule of injustice", the objections of former East Germans to these terms rose. Their life in East 
Germany appeared to have been kidnapped by a memory discourse dominated by "Stasi" and "Stasi state". ${ }^{28}$

The analysis of these issues is a rich field of future study which only now, as the events become historicized, is being examined more closely while the dialogue about the past continues. ${ }^{29}$

\section{The future of the Stasi Records Archive}

The 30th anniversary of the fall of the Berlin Wall and German unification in 2019 demonstrated the continued interest in using the Stasi records. ${ }^{30}$ They have become a fixture within the national discourse over the German past. At the outset, the concept of having a stand-alone archival institution headed by a commissioner was not following a long-term plan but was driven by historical circumstances. ${ }^{31}$ The overwhelming need to deliver on the promise of access to the Stasi records on a lawful basis had to be addressed in the 1990s. The assumption was that within a decade, people's need for access would diminish, and integrating the archive into the national archival structure would easily be accomplished. But the demand for access to the records proved to be a longer-lasting need strongly continuing throughout the 2000s, both strengthening the status of the $\mathrm{BStU}$ as an institution and rendering its institutional change a more delicate policy choice.

In 2008, the Bundestag decided to begin the process of integrating the Stasi Records Archive into the Federal Archives (Bundesarchiv). ${ }^{32}$ The timetable however was left open as there was little desire to appear willing to diminish the process of dealing with the past by rushing this institutional change. ${ }^{33}$ A decade later, in the spring of 2019, the BStU and the Bundesarchiv handed a paper on the future of the Stasi records ${ }^{34}$ to the Bundestag, who had in 2016 mandated that both institutions should jointly prepare a plan for the transfer of the Stasi Records into the Federal Archives to secure their permanent preservation. ${ }^{35}$ In this concept paper, they propose that the "Stasi Records Archive" will be a new separate division within the Bundesarchiv with a special leadership. This "Stasi Records Archive" will continue the core of the BStU's work with special provisions to maintain its special character and symbolic significance to the nation's memory, to the victims as well as to the international community. Most importantly, the legal foundation for access to the records, the Stasi Records Act, will remain largely unchanged. ${ }^{36}$ In November 2020, the Bundestag approved the plan ${ }^{37}$ and legally finalized the integration of the Stasi Records Archive into the Bundesarchiv at the end of the term of the Federal Commissioner mid-2021.

After almost three decades in existence, the Stasi Records Archive has established its own place in German public discourse about the East German past. It has exhibited the "power of archives" in its own unique way. ${ }^{38}$ It was instrumental in providing documentation to millions of individuals to clarify their fate in the dictatorship. It supported transitional justice 
mechanisms from trials and vetting to rehabilitation to memorialization. As the prosecution of Stasi and SED members was not immensely successful, ${ }^{39}$ as the basis for reparations was slow in coming and tedious in pay-out, ${ }^{40}$ and as the majority's desire to reckon with the past or even discuss the past subsided in the harder realities of the unification process, the agency of the $\mathrm{BStU}$ was a continuing voice reminding society of this past. In this sense, the Stasi Records Archive through its unique history began to fulfill the kind of "symbolic reparation" 41 that monuments usually can provide. Furthermore, many victims see an advocate on the national stage in the person of the Federal Commissioner. It is because of this reality that the Bundestag has also incorporated with its November 2020 decision the legal basis for a new commissioner for the victims of the SED dictatorship beginning his or her tenure when the records are transferred to the Bundesarchiv. ${ }^{42}$

The current Federal Commissioner Roland Jahn often describes the archive and the records as a monument in and of itself, a "monument of surveillance". He renamed the former Ministry headquarters which are the home of the archive in Berlin, "Stasi Headquarters. Campus for Democracy". ${ }^{43}$ This is part of a mission to turn the records and the archive at the historic site into an active arena for current discussions about the dangers of repressing human rights and the values of democracy. In this sense, the Stasi Records Archive already plays an active role in the conceptual view that "archivists must continue to be builders of the memory infrastructure". ${ }^{44}$ With its 30 -year interactive societal dialogue about the communist past, the archive has become a tool for the long-term work of "social reconstruction" and the "guarantee of non-repetition" 45 - a legacy from its unique historical origin as an archive from a revolution, which people fought for access to address the injustices of the past. It also provides what all archives do, a long-term resource for every new generation to ask their questions about the past, contributing to the development of public memory, seen as "an activity or process rather than an object or outcome". ${ }^{46}$ The Stasi Records Archive is uniquely fitted to provide a model as an archival institution that uses the records of a repressive past to promote a continuous and active dialogue about human rights.

\section{Notes}

1 See: Jahn (2016).

2 See: Applebaum (2012), XXII.

3 Compare Maier (1997), Ch. 1, Losing Faith.

4 See: Gieseke (2014) and Münkel (2016).

5 A Stasi term for critical expression of thought, see: Engelmann et al. (2012).

6 See: Engelmann, Roger and Kowalczuk, Ilko-Sascha, hrsg. (2005).

7 See: Veen and Wurschi (2014).

8 See: Süß (1999).

9 See: Gauck (1991, p. 99).

10 See: Booß (2017).

11 Ibid.

12 As an example, see: United Nations (2015, p. 1). 
13 I am describing only the development in West Germany as the communist East had its own but different way of addressing the Nazi past. See Henry Leide's "Nazi-Criminals and State Security: East Germany's Secret Policy of the Past" (Leide, 2005) or Annette Weinke's overview (Weinke, 2018).

14 See: Romeike (2016, p. 41).

15 The citizens' committees were adamant about denying or at minimum severely restricting access to the Stasi's information by Western intelligence services, which is reflected in the respective articles in the Stasi Records Act.

16 The European Network of Official Authorities in Charge of the Secret Police Files is the umbrella organization of these archives. Available at www.bstu.de/ en/international/european-network/, accessed 15 March 2019.

17 Stasi Records Act (StUG). Article 35. Federal Commissioner for the Records of the State Security Service of the Former German Democratic Republic. Available at www.gesetze-im-internet.de/stug/, accessed 3 March 2019.

18 See: Booß (2017), Kobylinski (2015), and Lahmann (1992).

19 Pietrkiewicz/Burth, in: Geiger, Klinghardt, and Burth (2006), $\mathbb{S} 35$, Rn. 13; all three commissioners were voted into office with a large majority. Available at www.bstu.de/en/the-agency/tasks-of-the-bstu/, accessed 3 March 2019.

20 Stasi Records Act (StUG). Article 1. Purpose and Scope. Available at www.bstu. de/en/the-agency/legal-basis/, accessed 3 March 2019.

21 The Stasi Records Act purposefully avoids the terms "victims" and "perpetrators" ' and speaks of "persons concerned" and "employees" of the Stasi.

22 The outing of informants became a widespread practice, not quite fulfilling the hopes of instigating the dialogue about concrete responsibility. This is a topic deserving of a broader discussion. See: Espindola (2015), Gieseke (2009a), and Hovestädt (2018).

23 The criminal prosecution of SED and Stasi crimes were largely an issue of the 1990 s and statutes of limitations have passed for almost all crimes. See: Marxen, Werle, and Schäfter (2007) or Schißau (2006).

24 Stasi Records Act (StUG). Article 37. Duties and Authority of the Federal Commissioner. Available at www.bstu.de/en/the-agency/legal-basis/, accessed 3 March 2019.

25 Website BStU. Available at www.bstu.de/ueber-uns/bstu-in-zahlen/, accessed 3 March 2019.

26 See: Forest, Johnson, and Till (2004, p. 363); “Deutscher Bundestag” refers here to the report of the first committee established by the German parliament on the "Reappraisal of the history and consequences of the SED-Dictatorship in Germany" (translation by author), an additional TJ measure short of a truth commission. Available at http://dipbt.bundestag.de/doc/btd/12/078/1207820. pdf, accessed 7 March 2019.

27 See: Jarausch, Ostermann, and Etges (2017, p. 2).

28 See: Kittel (2017, p. 100; translation by author).

29 See, for example: Großbölting and Lorke (2017), Jarausch (2014), and Stan and Nedelsky (2015).

30 Bundestag resolution June 9, 2016, "Unwaveringly continuing reappraisal of the SED dictatorship" (Print Material 18/8705). The resolution affirmed the political commitment to permanently preserve the entirety of all Stasi records and maintain the visibility of the Stasi Records Archive as an international model for addressing injustices of the past as well as a symbol of the Peaceful Revolution of 1989.

31 See: Strothmann (1995), Huskamp Peterson (2005, p. 32), and Booß (2017). Also, the idea of treating the records as a "regular" national archival collection and integrating them right away into the national archives, was untenable in 1990. The fear that they would be subjected to the usual archival rules including a 30 year "cooling-off" period was seen as subverting the revolutionizers idea of access. Some distrust can still be felt 30 years later in public discussions around the integration into the Bundesarchiv in 2021. 
32 Gedenkstättenkonzept des Bundes von 2008, 6. Available at www.bstu.de/assets/ bstu/de/Downloads/bstu-in-zukunft_bundestag_fortschreibung-gedenkstaettenkonzept-bund.pdf, accessed 8 March 2019.

33 Throughout that period, there were many discussions on all sides of the political spectrum, with proponents of a quicker end to the special institution status as well as proponents of no end to the specialty status at all. With a backdrop of a risk of appearing too eager to end the reappraisal of this past, it is obvious why the process became so lengthy. These debates deserve an exploration of their own; for some pointers, see: Beleites (2004), Engelmann, Die herbeigeschriebene "Legitimationskrise" Anatomie einer Kampagne gegen die Stasi-UnterlagenBehörde (2007).

34 Concept paper. Available at www.bstu.de/assets/bstu/en/Downloads/Agency_ Future-of-the-Stasi-records_en.pdf, accessed 6 April 2019.

35 The concept paper makes ample note of the need for preservation and digitization of the records and the need to construct professional archival buildings. Under the auspices of the Bundesarchiv, those necessary investments are meant to be secured for the long-term future.

36 While this case study focuses on the future of the records, it is worth noting that the continuation of the position of a Federal Commissioner as an ombudsperson for the victims situated at the Bundestag was an important feature for the acceptance of the transition of the records into the federal archives. See the reaction of the largest victims' organization: https://www.uokg.de/2020/11/stasi-unterlagengesetz-sed-opferbeauftragter-grosse-erwartungen-in-die-arbeit-der-oder-desopferbeauftragten/ accessed 19 December 2020.

37 Parliamentary protocol of the session of Deutscher Bundestag on November 19., 2020 and enactment documents on the transfer of the Stasi Records Archive into the Bundesarchiv: https://www.bundestag.de/dokumente/textarchiv/2020/kw47de-bundesarchivgesetz-stasi-unterlagen-804234, accessed 19 December 2020.

38 See: Hovestädt (2018), Gieseke (2009), and McAdams (2001); the "Power of Archives" is meant as an allusion to Randall Jimerson's work of the same name (Jimerson, 2009).

39 See: Marxen, Werle, and Schäfter (2007).

40 See: Vollnhals (2016).

41 See: Barsalou and Baxter (2007, p. 2).

42 See note 36.

43 Available at www.bstu.de/ueber-uns/stasi-zentrale-campus-fuer-demokratie/, accessed 15 March 2019.

44 See: Stinnett (2009, p. 17).

45 See: Barsalou and Baxter (2007, p. 10).

46 See: Forest, Johnson, and Till (2004, p. 358).

\section{Bibliography}

Applebaum, A. 2012, Iron Curtain: The Crushing of Eastern Europe 1944-1956. New York: Doubleday.

Barsalou, J., and Baxter, V. 2007, The Urge to Remember: The Role of Memorials in Social Reconstruction and Transitional Justice. Washington, DC: U.S. Institute for Peace. Available at www.usip.org/sites/default/files/srs5.pdf, accessed 8 March 2019.

Beleites, J. 2004, "Brauchen wir noch ein Sonderrecht für Stasi-Unterlagen? Zum aktuellen Diskussionsstand um das Stasi-Unterlagen-Gesetz (StUG), in: Bensussan, A., Dakowska, D., and Beaupre, N. (hrsg.), Die Überlieferung der Diktaturen: Beiträge zum Umgang mit Archiven der Geheimpolizei in Polen und Deutschland nach 1989. Essen: Klartext Verlag, pp. 81-100. 


\section{Dagmar Hovestädt}

Booß, C. 2017, Die Akteneinsicht: Von der revolutionären Aktion zum Gesetz, 24 April. Deutschland Archiv. Available at www.bpb.de/geschichte/zeitgeschichte/ deutschlandarchiv/246990/die-akteneinsicht-von-der-revolutionaeren-aktionzum-gesetz, accessed 15 February 2019.

Engelmann, R. 2007, “Die herbeigeschriebene 'Legitimationskrise' Anatomie einer Kampagne gegen die Stasi-Unterlagen-Behörde," Deutschland Archiv, vol. 40, no. 6, pp. 1071-1078.

Engelmann, R., Florath, B., Heidemeyer, H., Münkel, D., Polzin, A., and Süß, W., eds. 2012, Das MfS-Lexikon: Begriffe, Personen und Strukturen der Staatssicherheit der DDR, 2 ed. Berlin: Ch. Links Verlag.

Engelmann, R., and Kowalczuk, Ilko-Sascha, hrsg. 2005, Volkserhebung gegen den SED-Staat. Eine Bestandsaufnahme zum 17. Juni 1953. Göttingen: Vandenhoeck \& Ruprecht.

Espindola, J. 2015, Transitional Justice After German Reunification: Exposing Unofficial Collaborators. New York: Cambridge University Press.

Forest, B., Johnson, J., and Till, K. 2004, "Post-Totalitarian National Identity: Public Memory in Germany and Russia," Social \& Cultural Geography, vol. 5, no. 3, pp. 356-380. Available at https://journalofburmesescholarship.org/pprs/ForestJohnsonTill-PostTotal.pdf, accessed 8 March 2019.

Gauck, J. 1991, Die Stasi Akten. Reinbek: Rowohl TB.

Geiger, H., Klinghardt, H., and Burth, J., hrsg. 2006, Stasi-Unterlagen-Gesetz: Kommentar, bd. 2. Stuttgart: Verlag Kohlhammer.

Gieseke, J. 2009a, 20 Jabre Stasi-Aufarbeitung: Vorbild oder Auslaufmodell? Abgerufen am 20. February 2019 von Bundeszentrale für politische Bildung, 29 June. Available at http://m.bpb.de/geschichte/deutsche-einheit/deutsche-teilungdeutsche-einheit/43839/stasi-aufarbeitung.

—. 2009b, "Die Stasi und ihr IM," in: Sabrow, M. (hrsg.), Erinnerungsorte der DDR. München: Beck, pp. 98-108.

- 2014, The History of the Stasi: East Germany's Secret Police, 1945-1990. New York: Berghahn Books.

Großbölting, T., and Lorke, C. 2017, Deutschland seit 1990: Wege in die Vereinigungsgesellschaft, T. Großbölting and C. Lorke (hrsg.). Stuttgart: Franz Steiner Verlag.

Hovestädt, D. 2018, Beyond the Obvious: The Stasi Records Archive as Transitional Justice Tool in an International Context, 20 August. ECPR-European Consortium of Political Research. Available at https://ecpr.eu/Filestore/PaperProposal/83b2acab34e1-4870-8665-3f2019a4e258.pdf, accessed 5 March 2019.

Huskamp Peterson, T. 2005, Final Acts. A Guide to Preserving the Records of Truth Commissions. Baltimore, MD: John Hopkins University Press. Available at www. wilsoncenter.org/sites/default/files/Petersonfinpdf.pdf, 3 March 2019.

Jahn, R. 2016, "Die offenen Akten sind ein Geschenk der Revolution," Horch und Guck, vol. 25, no. 82-83, pp. 48-52.

Jarausch, K. H. 2014, "Between Myth and Reality: The Stasi Legacy in German History,” GHI Bulletin Supplement, vol. 9, pp. 73-83.

Jarausch, K. H., Ostermann, C. F., and Etges, A. 2017, "Rethinking, Representing, and Remembering the Cold War: Some Cultural Perspectives," in: Jarausch, K. H., Ostermann, C. F., and Etges, A. (eds.), The Cold War: Historiography, Memory, Representation. Berlin and Boston: Walter de Gruyter, pp. 1-18.

Jimerson, R. C. 2009. Archives Power: Memory, Accountability, and Social Justice. Washington, DC: Society of American Archivists. 
Kittel, S. 2017, “Gedächtnis und 'Post-Gedächtnis' 'Stasi'-Erzählungen zwischen Vergessen, Verschleiern und Erinnern,” in: Großbölting, T., and Lorke, C. (hrsg.), Deutschland seit 1989: Wege in die Vereinigungsgesellschaft. Stuttgart: Franz Steiner Verlag, pp. 97-116.

Kobylinski, A. 2015, Der verratene Verräter: Wolfgang Schnur: Bürgerrechtsanwalt und Spitzenspitzel. Halle: Mitteldeutscher Verlag.

Lahmann, B. 1992. Genosse Judas: Die zwei Leben des Ibrahim Böhme. Berlin: Rowohlt Verlag.

Leide, H. 2005. NS-Verbrecher und Staatssicherheit: Die geheime Vergangenheitspolitik der DDR. Göttingen: Vandenhoeck \& Ruprecht.

Maier, C. S. 1997. Dissolution: The Crisis of Communism and the End of East Germany. Princeton, NJ: Princeton University Press.

Marxen, K., Werle, G., and Schäfter, P. 2007. Die Strafverfolgung von DDR-Unrecht: Fakten und Zablen. Berlin: Stiftung Aufarbeitung.

McAdams, A. J. 2001. Judging the Past in Unified Germany. New York: Cambridge University Press.

Münkel, D. (ed.). (2016). State Security: A Reader. Berlin: BStU.

Romeike, S. 2016, Transitional Justice in Germany After 1945 and After 1990. Nuremberg: International Nuremberg Principles Academy.

Schißau, R. 2006, Strafverfahren wegen MfS-Unrecht: Die Strafprozesse bundesdeutscher Gerichte gegen ehemalige Mitarbeiter des Ministeriums für Staatssicherheit der DDR. Berlin: Berliner Wissenschafts-Verlag.

Stan, L., and Nedelsky, N. (eds.). (2015). Post-Communist Transitional Justice: Lessons from Twenty-Five Years of Experience. New York: Cambridge University Press.

Stinnett, G. 2009, “Archival Landscape: Archives and Human Rights,” Progressive Librarian: A Journal for Critical Studies \& Progressive Politics in Librarianship, vol. 32, pp. 10-20, Winter-Spring. Available at www.progressivelibrariansguild. org/PL/PL32/010.pdf, accessed 27 January 2019.

Strothmann, M. 1995, "Die Last der Vergangenheit: Zum Umgang mit den Stasi-Akten im wiedervereinigten Deutschland," Deutschland Archiv, vol. 28, pp. 806-822.

Süß, W. 1999, Staatssicherheit am Ende: Warum es den Mächtigen nicht gelang, 1989 eine Revolution zu verhindern. Berlin: Ch. Links Verlag.

United Nations. 2015, Rule-of-Law Tools for Post-Conflict States - Archives, 48. New York and Geneva: United Nations. Available at www.ohchr.org/Documents/ Publications/HR_PUB_14_4_Archives_en.pdf, accessed 23 January 2019.

Veen, H. J., and Wurschi, P. hrsg. 2014, "Es lag was in der Luft . . .”: Die Besetzung der Bezirksverwaltungen des MfS/AfNS in Erfurt, Subl und Gera. Weimar: Stiftung Ettersberg.

Vollnhals, C. 2016, "Rehabilitierung und Entschädigung der Opfer der SEDDiktatur," in: Heydemann, G., and Vollnhals, C. (hrsg.), Nach den Diktaturen: Der Umgang mit den Opfern in Europa. Göttingen: Vandenhoeck \& Ruprecht, pp. 127-155.

Weinke, A. 2018, "Die Bundesrepublik Deutschland - ein Fall von Transitional Justice avant la lettre," in: Mihr, A., Pickel, G., and Pickel, S. (eds.), Handbuch Transitional Justice: Aufarbeitung von Unrecht - hin zur Rechtsstaatlichkeit und Demokratie. Wiesbaden: Springer Fachmedien, pp. 249-274. 


\title{
11 France and the archives of the Algerian War
}

\author{
Gilles Manceron and Gilles Morin
}

In France, the National Archives were founded in September 1790, following adoption of the Declaration of the Rights of Man in 1789. The principle of freedom of access to archives for all citizens was also confirmed. ${ }^{2}$ It was officially declared that the archives of all state agencies and public authorities belonged to the nation and not to the organizations or authorities that produced them, that all citizens were entitled to consult these records and that the role of archives was not to act as custodians of state secrets but to enable citizens to consult documents retracing their history without impediment.

But it was not long before this fine principle was flouted. In 1800, responsibility for archives was transferred to the Ministry of the Interior and, when the First French Empire (1804-1815) was established under Napoleon Bonaparte, they became the "imperial archives" and, on 6 May 1812, an official order was issued banning access to archival catalogues. Under the monarchies that followed (1815-1848), the "archives of the kingdom" remained the property of the rulers and their administrations. A statutory period of 50 years was set during which documents would not be available for consultation. It was not until 1846 that readers were entitled to have access to original documents, and until 1850, under the Second Republic, that the first reading room was opened. During the Second Empire (1852-1870), the "imperial archives” remained under the Emperor's authority.

\section{Archives under state control}

With the advent of the Third Republic in the 1870s, the National Archives stayed under state control via the Ministry of Public Instruction, which used them to compile the "History of France", an account to be related in classrooms to foster national solidarity. The ministerial order of 16 May 1887 also set a minimum statutory closure period of 50 years, a principle that still applies today, ${ }^{3}$ although the length of this period was later modulated under different laws and in relation to different categories of archive.

Some ministries and authorities, such as the Ministry of Foreign Affairs, the Ministry of War, the Ministry of the Colonies, the Council of State and the 
Seine département police headquarters (which later became the Paris police headquarters), refused to comply with the legal requirement to transfer their records to the National Archives and continued to keep their own records. Following an unsuccessful attempt to drive through a law on archives, the government of the Popular Front bowed to circumstances in a decree dated 21 July 1936, Article 3 of which authorised authorities not having met the legal transfer requirement to maintain their own archives, provided they did so "within the framework of the law". This begs the question of why and for how long these authorities should continue to enjoy exemption from the transfer requirement in this way. For example, what real justification is there for letting the army manage its own historical archives - those that have existed for more than 50 years - when these are not "current archives"? Because these records are managed separately, how is it possible to be certain that they are being kept within "the framework of the law"? Even when government employees from France's National Archives are appointed to the Defence Historical Service (SHD - Service Historique de la Défense), the army continues to be ultimately responsible for the records held by the SHD. The French armed forces form a sort of "memory enclave" within the Republic. To make matters worse, in 2011 towards the end of Nicolas Sarkozy's presidency, not only was a general interministerial instruction (Instruction générale interministerielle [IGI] 1300) issued but, in addition, in late 2019, the armed forces were empowered to halt access to documents produced under their authority, irrespective of when they were issued or where they were stored (at the SHD, National Archives or elsewhere). They continue, after a fashion, to enjoy the "right to manage their own history", even though this is an integral part of French history and their archives (with the exception of recent documents containing current information of a sensitive nature relating to national security) should be accessible to the population as a whole.

\section{“Giscard” Law of 3 January 1979}

In 1959, under the Fifth Republic, responsibility for the National Archives was transferred from the Ministry of Primary and Secondary Education to the Ministry of Cultural Affairs. The law on archives of 3 January 1979 was adopted during Valéry Giscard d'Estaing's term as President (1974-1981). Article 33 refers officially to the abrogation of three laws dating from the French revolution. ${ }^{4}$ Yet it would be an exaggeration to say that this made archives and records even less accessible. Shortly before, the law of 17 July 1978 on "freedom of access to official documents" placed limits on the degree of secrecy that the authorities could exercise over documents concerning their citizens. Until then, the principle of secrecy had always applied in contradiction to the revolutionary laws. This new law set a standard statutory closure period of 30 years for archives, but made provision for numerous exceptions: 120 years for medical records and personnel files; 100 years 


\section{2}

for legal proceedings, notary deeds, registry office records and documents containing personal data; and 60 years for documents "potentially compromising privacy" or relating to "state security and national defence".

It was then that the concept of "privacy" began to be recognised as an issue. According to the Senator tasked with defending the proposed legislation, the aim was "mainly to avoid premature disclosure of documents which, while not necessarily about individual private lives, may concern controversial issues or troubled times (French Occupation and Liberation) and documents that had related to national security". Since then, the notion of "protecting individual privacy" has been used as an excuse to prevent disclosure of information about crimes committed under the Occupation or during the colonial wars. To protect the "privacy" of the perpetrators of these crimes or, where relevant, their descendants, documents that "reveal behaviour under conditions which, if known, could be damaging to those responsible for such behaviour" must not be made public. According to this rationale, the records showing that senior civil servant (and later government minister) Maurice Papon was guilty of complicity in crimes against humanity in Bordeaux in 1942 should have remained secret to "protect the privacy" of Papon and his family. The case brought against Papon that culminated in his conviction in 1998 was only possible because of an archivist who was prepared to flout the law and deliver documents to the son of a deportee who perished in a Nazi concentration camp (Slitinski, 1983; Conan, 1998). Other than the provisions in the laws on amnesty, there are absolutely no grounds for covering up unspeakable deeds on the pretext of "protecting the privacy" of the perpetrators and certainly not their descendants, who are in no way responsible for these acts. "Protecting privacy" cannot be used as justification for attempts by government to plaster over chapters of French history, be they acts perpetrated under the Occupation, cases of torture or assassinations carried out by members of the French armed forces during the Algerian War or terrorist crimes committed by members of the OAS. ${ }^{5}$

In 1995, the then French Prime Minister Edouard Balladur tasked Guy Braibant, an honorary member of the Council of State, with reviewing this law and formulating proposals. In the report that he submitted on 28 May 1996, he recommended a number of measures, which represented a real move towards more open archives. The bill of 15 July 2008, adopted under Nicolas Sarkozy, also seemed to be a step in the same direction but in fact merely created further barriers to archival access.

\section{“Sarkozy” Law of 15 July 2008}

This law professed to make immediate access to public archives the norm, a principle that echoed the law of Messidor Year II, but that was almost straightaway given the lie, because provision was made for number of statutory closure periods and for the notion of "permanent withholding" for 
"weapons of mass destruction" - including the poison gases used a century earlier in World War I! ${ }^{6}$ Most of the existing closure periods were curtailed, with those for registry office records and notary deeds, for example, reduced from 100 years to 75 , and those for records "relating to national defence, state security and public order" cut from 60 to 50 years. But this was not systematically the case because, in particular, some judicial police archives now have the same status as legal archives and thereby closure periods of 75 rather than 60 years. The law also upholds the rather vague notion of documents "transmission of which would infringe privacy" or that "contain an appraisal or value judgement on an individual that could cast him or her in a poor light". The result is that records are not released, and the crimes committed by individuals are not brought to light and exposed. And most importantly, further non-legislative impediments were established shortly afterwards, which we shall be examining at a later stage.

As with earlier legislation, individual waivers may be granted to the statutory closure periods. The process is long and complicated, with the result that different researchers may receive different responses. No justifications are provided, unless an appeal is lodged with the Committee for Access to Official Documents (CADA - Commission d'Accès aux Documents Administratifs). ${ }^{7}$ Individual waivers seem either designed to open potential avenues of research or as privileges granted on an individual basis, in contradiction with one of the founding principles of the French Republic by which all citizens should have equal public service access rights.

The 2008 law, which is still in force, represented modest progress but contained its own contradictions. Three years later, its application was further complicated by the general interministerial instruction, a non-legislative text issued on 30 November 2011 towards the end of Nicolas Sarkozy's regime, which ran counter to the law by enabling authorities issuing documents marked "secret" to prevent their circulation by refusing to declassify them. When documents are stamped "secret" or "top secret", regardless of the date or subject concerned, archivists are obliged to request the issuing authority to declassify them, a process that has to be carried out for individual documents one by one (Veyssiere, 2019). In the meantime, archivists are required to put the documents in a sealed envelope bearing details of the disciplinary and professional sanctions or court sentences imposable on those found guilty of "compromising national military secrecy", researchers and archivists also running the risk of being barred from their professions. ${ }^{8}$ Attaching lasting importance to the "secret" stamp whenever it appears on a document - even though during the colonial wars it was sometimes added by superior officers to cover up the use of torture by their subordinates gives the French armed forces an excuse for not making documents available. In practice, it deprives victims' families and researchers of the chance to garner information on blatant abuses of human rights perpetrated during the colonial wars, particularly as a decree dated 2 December 2019 requires even stricter application of this 2011 interministerial instruction. ${ }^{9}$ 
In February 2020, in reaction to the "new impediment to research" (Vaïsse, 2019) represented by the general interministerial instruction of 30 November 2011, further aggravated by the decree of 2 December 2019 making its application even more stringent, the Association of French Archivists (AAF - Association des Archivistes Français) spoke up against the obligation incumbent on archivists to list "classified" documents and not pass them on to readers as they stand unless they have been declassified. ${ }^{10}$ The situation also sparked protests from numerous French and foreign researchers, with several thousand people signing a petition in this connection. ${ }^{11}$

\section{Archives of the colonial wars, including the Algerian War}

The archives of World War II, during which the Vichy Government and French institutions collaborated with the occupying Nazis, entered the public domain in their entirety on 8 May 2015, 70 years after the end of the war in Europe, following a class action from historians. A decree granting general exemption and enabling access to these archives was published on 24 December 2015 and implemented progressively in the corresponding archival institutions. However, many archives concerning the colonial wars during which human rights were violated by French law enforcement agencies had never been transferred or catalogued and consequently remained unavailable for consultation, even though their statutory closure periods had elapsed.

This led to strong demand for a general exemption to be decreed to provide open access to the archives of the Algerian War, along similar lines to the decree published in December 2015 for those of World War II. On 13 September 2018, during a visit to Josette Audin, the widow of Maurice Audin (a young mathematician and member of the Algerian communist party fighting for Algerian independence alongside the FLN) ${ }^{12}$, French President Emmanuel Macron published a statement acknowledging that her husband had been killed in Algiers in June 1957 by the troops who had taken him prisoner and that his death had been made possible by a system empowering the army to arrest all potential suspects. ${ }^{13}$ Yet thousands of other people lost their lives as a result of this system. The authorities also turned a blind eye to the torture inflicted by the army when interrogating and terrorising its prisoners. As Josette Audin wrote to Pierre Vidal-Naquet in September 1957, just a few weeks after her husband's disappearance and as he mentioned in his Mémoires, ${ }^{14}$ the vast majority of those abducted leaving their families without news were indigenous Algerians.

At this juncture, a few background details would perhaps not go amiss. During the first half of the 20th century, Algeria was considered an integral part of France and divided into départements. The Algerian War of Independence began on 1 November 1954 with a series of attacks organised by the FLN, which immediately set up groups of National Liberation Army (ALN - Armée de Libération Nationale) guerrillas throughout the country. 
A state of emergency was officially declared by law on 3 April 1955, conferring two powers on the French army which remained in place throughout the war: firstly, the right to arrest and detain suspects arbitrarily and, secondly, the right to try them in the military courts. In spring 1956, the French parliament voted to grant the "special powers" requested by Guy Mollet's Government, whereupon, in January 1957, the army was empowered to police the Algiers region. It arrested, interrogated and held people as it saw fit as part of a violent crackdown targeting not only the FLN-ALN fighters who were forming guerrilla groups and organising attacks, but also the members and supporters of the Algerian pro-independence parties, such as Messali Hadj's ${ }^{15}$ MNA,${ }^{16}$ or those joining it, the UDMA, ${ }^{17}$ the Ulamas ${ }^{18}$ and the PCA,${ }^{19}$ and any of their suspected supporters. Also targeted were all those belonging to networks involved in fundraising, promoting or providing logistics support for the guerrillas, plus anyone suspected of having sheltered or assisted militant nationalists. The first half of 1957 saw the "Battle of Algiers", which marked the climax of the "wholesale crackdown" operated by the security forces, intelligence services and French police, which targeted far more than just members of the organizations involved in the war, the maquis fighters and the perpetrators of attacks. It was during this dissuasive terror campaign, designed not only to stamp out enemy organizations but also to cut its fighters off from all sources of support, that Maurice Audin disappeared in June 1957. Torture followed by widespread enforced disappearances, not to mention other crimes such as rape, were commonplace under what was effectively a reign of terror.

In the absence of individual files on persons "reported missing" or archive collections providing full details of disappearances, and with records being, at best, scattered over different locations and, at worst, containing forgeries such as the documents fabricated to substantiate the fiction of Maurice Audin's escape ${ }^{20}$ researchers, beginning with Pierre Vidal-Naquet (1972), opted to focus on analysing the military rationale and workings of the system of repression (Thénault, 2004; Branche, 2005, pp. 213-217). Their account of the rationale applied during the Algerian War documented the so-called arrest and detention system (Thénault, 2013) roundly criticised by Emmanuel Macron in his presidential declaration of September 2018. ${ }^{21}$

But this declaration begs the further question of whether France can admit that Maurice Audin was held, tortured and assassinated by members of the French armed forces, while continuing to remain silent about the thousands of others who suffered the same fate. It has a responsibility to give the families of all these missing people access to any documents in the public archives that could shed light on their disappearances. This responsibility is even greater when the disappearances were caused by military or civilian personnel acting under the authority of the state. A seminar was organised on 20 September 2019, under the auspices of the National Consultative Committee on Human Rights (CNCDH - Commission Nationale Consultative des Droits de l'Homme) and supported by the major French 
human rights and anti-torture organizations, ${ }^{22}$ during which emphasis was placed on the enormous progress made in recent decades in international law with regard to enforced disappearances. All victims of such disappearances, wherever they are in the world, should now benefit from the "Joinet principles" officially recognised by the United Nations, and which consist of truth, justice and reparation. But for this, access to archives is vital.

In the wake of Emmanuel Macron's declaration, and with the support of various associations, Malika Rahal and Fabrice Riceputi and a number of other historians ${ }^{23}$ set up a website called 1000autres.org, in order to put names and faces of the many people who went missing during the Battle of Algiers, Algerians whose identities were until then, for the most part, unknown. As Fabrice Riceputi (2020) explained during the seminar, although army archives may offer little written information about this "arrest and detention" system, indirect evidence is obtainable from civilian archives. The website was in fact created after Riceputi had consulted a record at the French National Overseas Archives (ANOM - Archives Nationales d'Outre-mer) in January 2018 originating in the Algiers Prefecture and documenting the cases of some 850 Algerians arrested by the armed forces in Algiers in 1957. ${ }^{24}$ This record provides the full names and addresses of the individuals concerned, their professions and the precise circumstances of their arrest. It also indicates that, when questioned by Prefecture officials at the request of their families regarding the fate of these detainees, the 10th Parachute Division of the French army had, in the vast majority of cases, been unable or was unprepared to provide answers. In 1958, the Secretary General of the Prefecture, Paul Teitgen, had informed Pierre Vidal-Naquet that the Algiers Prefecture was compiling a file of this type. In addition, in May 1957, also acting on information from Paul Teitgen, Maurice Garçon, a lawyer and the Secretary General of the Commission for the Protection of Human Rights and Fundamental Freedoms (Commission de sauvegarde des droits et libertés individuels) requested access to this material, only to be brushed off with a categorical refusal. What did this file contain? Almost as soon as the police's powers were transferred to General Massu's 10th Parachute Division on 7 January 1957, the Algiers Prefecture, the Minister Robert Lacoste, the Attorney General Jean Reliquet and the military authorities began to receive reports of missing persons from lawyers and families, who knew exactly who was to blame, namely the law enforcement agencies and, in most cases, the army. Reports came from people who had no news of their relatives and were very worried, because like everyone else in Algiers at the time, they were perfectly aware that the army was torturing and spiriting away its detainees more or less clandestinely in dozens of different places. To respond to these enquiries, on 23 February 1957, Pierre Bolotte, Head of Cabinet to Serge Baret, IGAME ${ }^{25}$ Prefect of Algiers, tasked one of his agencies, the North African Liaison Department (SLNA Service des Liaisons Nord-Africaines), with collecting them together for referral to the appropriate authorities, the intelligence services and the 10th 
Parachute Division, as "requests for information about missing persons from their next-of-kin".

A few weeks later, the head of SLNA estimated that "fewer than a third of the families concerned were daring to contact" him over missing relatives detained by the armed forces of whom they were without news. Despite this, in the first two months, he still managed to collect 500 reports. According to the last statistics on record, by the end of 1958 no less than 2,039 reports had been received by his department, mostly relating to arrests in 1957 . But only the first 850 of these missing persons' reports still remain in the ANOM today. Some months later, this same department head was forced to admit that, in $70 \%$ of cases, either the army failed to respond, or its replies were, in his view, "inadequate" or "not valid". ${ }^{26}$ These 850 records form the basis for the 1000autres.org database. They do not constitute a complete list of persons reported missing and/or known to have died. The database contains a few well-known examples, not least those of Maurice Audin and Henri Alleg ${ }^{27}$ whose disappearances were rapidly reported to the SLNA by their wives, and Djamila Bouhired, who was reported missing by her lawyer Jacques Vergès. The majority, though, are unknown quantities. What happened to them after they were arrested? This is the question asked on the 1000autres.org website in its appeal for information. It is therefore a search tool in the most literal sense of the term. For who other than their friends, families and descendants can identify the people concerned?

Other written evidence tends to confirm that those reported missing were in fact dead, because several years later families were still appealing in the press for news of 1957 arrestees. The four main sources are, firstly, a brochure entitled Le Cahier Vert published by Nils Andersson's La Cité in 1959 containing some 175 reports of missing persons collected in August of that same year in Algiers by lawyers Maurice Courrégé, Michel Zavrian and Jacques Vergès. Virtually all date from 1957. In his postscript to this document, Pierre Vidal-Naquet was quick to describe the system of enforced disappearances operated by the French armed forces ${ }^{28}$ (Vergès, Zavrian, Courrégé, 1959, p. 52). Another source is the many letters reporting disappearances, at times accompanied by records of the internal investigations conducted by the armed forces, sent to the civilian and military authorities, which are now scattered across various collections: at the SHD, the ANOM, the French National Archives, particularly in the archives of the President of the Republic, who frequently received and continues to receive numerous enquiries, and the International Red Cross (ICRC). But none are specifically catalogued as relating to missing persons. Lastly, there are the archives of the two Commissions for the Protection of Human Rights and Fundamental Freedoms that were successively in operation from May 1957 until 1962, recording numerous instances of abuse and enforced disappearances, many of which relate to Algiers and to 1957 . These bulky records are now kept at France's National Archives ${ }^{29}$ and include numerous "individual files" unfortunately still partially classed as "secret" in 2019. For 171 cases, 
the members of these Commissions admitted that the individuals concerned were no longer alive but were unable to explain how they had died. These archives also contain a series of named records for almost 2,000 missing persons, a mixture of Algerians and extremist European activists, ${ }^{30}$ whose disappearances were reported at different stages of the war, in Algeria and in France. In principle, each record corresponds to a file on an investigation mandated by the Commission.

A final point worth mentioning concerns the appeals for information about missing persons published in the Algerian press, in Al Chaab and Alger Républicain, as of September 1962, in other words, following the release of camp and prison detainees. These were analysed by Malika Rahal and enabled some 300 further names to be added to the SLNA database used for the 1000autres.org website. But this does not answer Jules Roy's essential question, a question that has haunted thousands of families for over 60 years: "The thousands of others . . ., where are they?" Needless to say, none of the sources described previously provides even the slightest answer to this gruesome question. It should not be forgotten that, in those rare cases where disappearances were reported to the police, the investigations carried out were summary to say the least, and the files on them subsequently unceremoniously cancelled by the French Government in what amounted to self-amnesty in $1962 .{ }^{31}$ For their part, the enquiries conducted by the Commissions for Protection always subscribed to the military versions of events designed to obfuscate what really happened to those reported missing. Nevertheless, the website 1000 autres.org is slowly but surely bringing a substantial number of victims of enforced disappearances out of colonial obscurity.

By consulting other records and archives, it should be possible to document further missing persons' cases. The records of the International Committee of the Red Cross (ICRC) are a particularly promising source of information, as was explained by Daniel Palmieri, the organization's head of historical research, at the seminar mentioned previously. ${ }^{32} \mathrm{He}$ informed the assembled gathering that ICRC inspections carried out between February 1955 and March 1962 at several hundred detention centres in Algeria had culminated in some 1,000 investigations, the files which are freely consultable at the ICRC's archives in Geneva, including those marked "secret", "highly confidential", "private" or "for internal use only".

Little by little steps began to be taken under François Hollande's presidency (2012-2017) $)^{33}$ towards making French archives for this period freely accessible. On 19 March 2016, President Hollande even hinted that all archives should become part of the public domain: "Since 2008, our archives for this period have for the most part been openly accessible but, let me say here and now, that every single one of them should be accessible and available for consultation by the public at large". This text no longer features on the French Government website. Much still remains to be done and, as we have seen, there are now new obstacles threatening this fledgling 
process. Following Emmanuel Macron's declaration in September 2018, an order was published in the Official Gazette of 10 September 2019, ${ }^{34}$ but this only concerned a series of documents about the Audin affair - including some forged by the armed forces - that had already been brought to his family's knowledge several years before. It is other records that are more likely to shed light on the reasons why Maurice Audin was assassinated. For this, much more extensive measures will be needed to make all the archives for this period accessible on a blanket basis, rather than just those handpicked by the French Government for transmission to the families or for consultation by historians. ${ }^{35}$ Surely, it should be the State's role to afford historians liberal access to the archives for the period, so that they can freely consult the fonds they consider useful for their research, rather than "steering" them in a specific direction by making its own selection? And, as we have seen, the decree of December 2019 tightening up application of the provisions governing national military secrecy imposes more stringent or longer periods of secrecy and is therefore a backwards step. ${ }^{36}$

Researchers need to be given full access to all the archives from this period. It is also high time that the rule of silence maintained by the armed forces since the time of the Algerian War with regard to these events should cease, as suggested by Emmanuel Macron in his declaration on 13 September 2018. Leading figures in government and the armed forces should appeal to the French military personnel of the time to recount their experiences and deposit any material in their possession in the archives.

\section{What scope for a general exemption?}

A second general exemption covering "all those reported missing during the Algerian War" was announced on 13 September 2018 in the President's statement on the Audin affair. This was to follow on from the order specific to the case of Maurice Audin mentioned earlier. Thousands of Algerian families are now hoping that this will enable them to obtain information about those who, like Maurice Audin, went missing through acts perpetrated by the French law enforcement agencies. There were other individuals who went missing during this war: indigenous Algerians, at the hands of some of the leaders of the FLN-ALN or because of in-fighting between Algerian nationalists; French military personnel; and European Algerians, at different stages in the war, in particular after 18 March 1962 for, though the war between FLN-ALN and France was officially over, there were still armed confrontations, as the OAS refused either to accept the ceasefire and Algerian independence or to lay down its arms. For example, on or around 5 July 1962, a large number of European civilians disappeared in the Oran region never to reappear. The families of all those who disappeared involuntarily during the Algerian War are entitled to the same rights. But the only official action taken to date relates to French military personnel and European Algerians and, to a lesser extent, 
harkis. ${ }^{37}$ Yet, historically, commemoratively, legally and archivally, France is directly implicated in relation to those who disappeared through action on the part of French law enforcement agencies acting under the auspices of the State.

In 2004, to enable the families of European civilians who disappeared during the war or the months that followed to pick up their trace, the management of the French National Archives decided to allow them access to the files drawn up by the French authorities following the Evian Accords ${ }^{38}$ (Liskenne, 2015). On 1 July 2004, the archive department at the Ministry of Foreign Affairs embarked on an inventory of its records on people "missing and/or presumed dead in Algeria during the final months of French rule (1962)". Efforts were made to locate these records and two officers seconded to the department for the purpose of creating a detailed database for subsequent uploading to the Ministry's website. ${ }^{39}$ The inter-ministerial task force for repatriates and the repatriates' associations also stepped in to ensure that the families and heirs of missing persons obtained access to this material. Commemorative measures were belatedly taken for the harkis, who mostly disappeared after Algerian independence. Nothing of this kind has been done for the native Algerians who disappeared at the hands of the French law enforcement agencies.

One example was quoted by Chloé Leprince, a journalist at France Culture, following the seminar at the National Assembly. The children of Moktar Boucif, a headmaster in Thiersville (Mascara region) and a member of the Algerian pro-independence communist party, know nothing about the circumstances leading up to their father's arrest in April 1958 and his subsequent death. Senouci Boucif, then aged 7 but now retired, recalls his father being roughly arrested at about 2 o'clock in the morning and has an enduring memory of seeing him behind barbed wire fencing at the barracks where the family had heard he was being held. A book published in 2017 accuses Boucif of having masterminded, just before his arrest, the "despicable assassination" of Félix Vallat, pied-noir ${ }^{40}$ mayor of Thiersville, where Boucif was a headmaster (Alonso, 2017). By virtue of the exemption, the mayor's three sons are entitled to have access to the archives relating to the circumstances of their parents' murder but Moktar Boucif's children have no such right to consult the records of their father's incarceration and subsequent assassination (Leprince, 2019). Such double standards with regard to access to archives in a Republic that condemns discrimination and claims to have learned from the errors of the past can only be described as outrageous.

There is clearly every reason to consider creating an information office at military archives for families looking for records about their relatives, similar to that successfully established at the French National Archives for Europeans reported missing. All too often, families struggle because of the language barrier and the difficulties inherent in archival searches. But public archives are there to serve all citizens, regardless of nationality, who may be 
interested in consulting them. A department could be set up to assist those seeking information about the atrocities committed by the law enforcement agencies, finally acknowledged by the French President in 2018. ${ }^{41}$

Moreover, in cases where records have been destroyed, like some of those relating to the crackdown on the October 1961 demonstrations in Paris, special efforts could be made to cross-reference existing documents and flag up any missing elements. The guide to research on those who went missing during the Algerian War published by French National Archives in March 2020 could be extended to include this information, or to list fonds where duplicates may exist to complete the picture. ${ }^{42}$

\section{Need for a general exemption extending to all archives of the era}

For the colonial wars, Emmanuel Macron's most recent decision following the order of 9 September 2019 authorising access to archives regarding the disappearance of Maurice Audin should also apply to all persons reported missing during the Algerian War and to all public records for that period. As with the previous order concerning World War II, this principle should extend to documents from the post-war period. The 2015 inter-ministerial order on World War II concerns archives up to the end of the 1950s where these deal with attempts to cover up information about collaboration during the German Occupation. For the Algerian War, the period concerned would need to extend at least up to the 1968 amnesty laws, ${ }^{43}$ which would mean that the limit for consulting documents would extend back 52 years. This is consistent with the 50 -year statutory closure period stipulated in the 2008 legislation and would make court files immediately accessible.

There is probably information in the archives that researchers could access using their own techniques and methods to track down people who went missing during the Algerian War for reasons ascribable to the French law enforcement agencies. But, for this, they would need to enjoy the broadest possible access to the war archives, because the rare missing persons' records available cannot possibly hope to suffice. Access to all the archives from the period, and especially the records of internment camps and detainee sorting centres, prisoner detention records, military units' operations diaries, etc., is therefore vital.

There can surely be no reason why France should not allow very extensive, if not full, access to its Algerian War archives. A good 58 years after the end of the war, surely enough time has elapsed for an objective analysis to be made of the history of this period? Today there remain a few survivors, some of whom would still be able to recount their experiences and put a more realistic slant on archives often doctored or deliberately designed to mislead, those regarding Maurice Audin being a case in point. 


\section{A crucial civic issue for France and beyond}

Military secrecy and the fundamental interests of the State cannot be allowed to override human and citizens' rights. Archivists should not have to emulate Brigitte Laîné and bend the law in order to uphold their professional codes of conduct and defend human rights. Having given evidence in 1999 in support of Jean-Luc Einaudi, who was being sued by Maurice Papon over the existence of archives on the crackdown on Algerian demonstrations in Paris on 17 October 1961, this courageous archivist was then hauled over the coals and unfairly sanctioned by her hierarchy. To quote Jean-Yves Mollier (2018), "not only was she the chief heritage archivist at Paris Archives that many of us knew so well, but she was also a sort of latter-day Antigone".

The issues at stake not only concern our knowledge of a period of contemporary French history but are also vital to civil society. They are not unconnected with the political and sectarian forces in France that feed on the silences of the past and on history's refusal to face the truth about the colonial period. Making archives openly accessible will not only help defuse the tensions inherent in teaching colonial history but is also one of the prerequisites for present and future citizens to be able to share a common and dispassionate awareness of the past. It would also be a useful lesson for citizens in general, not just in France and Algeria but also those in all other places in the world.

On 21 June 2020, the Association of French Archivists, the French Association of Contemporary Historians in Higher Education and Research (AHCESR - Association des historiens contemporanéistes de l'enseignement supérieur et de la recherche) and the Josette \& Maurice Audin Association wrote to the Prime Minister urging that he remove the obstacles to access to pre-1970 French archives, in particular those relating to the Algerian War, which placed the administrative documents in contradiction with the letter of the law. They had already decided that, if the Prime Minister failed to respond positively to their request, they would lodge an appeal with the Council of State, demanding that the provisions in these texts interfering with the freedom to conduct research be rescinded. Readers with sufficient knowledge of French may like to take a look at François Demerliac's documentary "Après l'affaire Audin. Les disparus et les archives de la guerre d'Algérie" (What followed the Audin affair: missing persons and archives of the Algerian War), available online on the websites of the Algerian Cultural Centre in Paris (Centre culturel algérien de Paris) and the Colonial and Postcolonial History Association (Association histoire coloniale et postcoloniale) https://histoirecoloniale.net/Le-film-Apres-l-affaire-AudinLes-disparus-et-les-archives-de-la-guerre-d.html. This documentary offers an overview of the problems that have arisen with regard to this particular issue in the two years since the statement made by the French President on 13 September 2018. 


\section{Notes}

1 The idea of "public archives" stems from the 1789 Declaration of the Rights of Man, Article 15 of which states that: "Society has the right to require of every public agent an account of his administration".

2 The law of 24 June 1794 (7 Messidor Year II) stipulates (Article 37) that "All citizens may, on the prescribed dates and times, require all repositories to afford them access to the documents in their possession".

3 In contrast to the revolutionary law of 7 Messidor Year II, passed a century earlier, reference to which was actually struck out of the original copy of the decree of 12 January 1898 on the French National Archives (see the facsimile of the original in 1979. Genèse d'une loi sur les archives, Comité d'histoire du ministère de la Culture, La Documentation française, 2019, p. 73).

4 The laws of September 1790, June 1794 and October 1796.

5 The OAS (Organisation de l'Armée Secrète - Secret Army Organization) was an undercover organization created in 1961 to oppose Algerian independence.

6 Article L 213-2. II. Public archives may not be made available for consultation if they contain information that could facilitate the design, manufacture, use or location of nuclear, biological or chemical weapons, or any other weapons with direct or indirect effects capable of causing similar levels of destruction (French version available on the Légifrance website. Available at www.legifrance.gouv.fr/ affichTexte.do?cidTexte=JORFTEXT000019198529\&categorieLien=id).

7 Appeals may be lodged with the CADA, by those to whom an authority refuses to make available documents kept in the public archives, the CADA's opinion not, however, being binding. If the authority maintains its decision, those concerned may refer their case to the administrative courts.

8 IGI 1300 issued in 2011, Article 66, pp. 50-51 (available for consultation in French on the Légifrance website. Available at www.legifrance.gouv.fr/ affichTexte.do?cidTexte=JORFTEXT000024892134\&categorieLien=id. Under the Penal Code, anyone found guilty of "compromising national military secrecy" shall be liable for up to five years of imprisonment, a fine of 75,000 euros and, in the specific case of archivists, banned from exercising their profession ("the activity in the exercise or on the occasion of which the offence was committed", in the words of the text).

9 Available at www.legifrance.gouv.fr/eli/decret/2019/12/2/PRMD1928053D/jo/.

10 See the declaration by the Association of French Archivists: " Le "crépuscule des archives" ? Entre accès restreint pour les citoyens et contraintes professionnelles pour les archivistes " www.archivistes.org/Le-crepuscule-des-archives-Entreacces-restreint-pour-les-citoyens-et (in French only).

11 The protests of French and foreign historians were published in the daily newspaper Le Monde, on 14 February 2020. Available at www.lemonde.fr/idees/ article/2020/02/13/nous-denoncons-une-restriction-sans-precedent-de-l-accesaux-archives-contemporaines-de-la-nation_6029398_3232.html. Concurrently, Mediapart, published an article. Available at https://blogs.mediapart.fr/gillesmanceron/blog/130220/secret-defense-contre-l-histoire-fermeture-des-archivesdes-repressions-coloniales, and a petition was launched. Available at http://chng. it/qGrqBBbZ.

12 Front de Libération Nationale, a political party that supported Algerian independence.

13 Available at www.elysee.fr/emmanuel-macron/2018/09/13/declaration-dupresident-de-la-republique-sur-la-mort-de-maurice-audin.

14 "In this letter, written in early September, Josette Audin emphasised that her husband's case was nothing unusual, for Algerian Muslims were disappearing every day.” (Vidal-Naquet 1998, p. 61). 
15 An Algerian politician who played a pioneering role in the process that culminated in independence.

16 National Algerian movement.

17 The Union Démocratique du Manifeste Algérien "Democratic Union of the Algerian Manifesto" was an Algerian political party created by Ferhat Abbas in 1946.

18 Algerian religious association created in 1933.

19 Algerian communist party.

20 Gendarmerie reports of "prisoners shot while trying to escape" often provided the legal justification for summary executions.

21 Available at www.elysee.fr/emmanuel-macron/2018/09/13/declaration-du-president-de-la-republique-sur-la-mort-de-maurice-audin (in French only).

22 At the French National Assembly, on the subject of "Missing persons who disappeared during the Algerian War at the hands of the French law enforcement agencies: truth and justice?", the videos of which have been published at https:// histoirecoloniale.net/Les-video-de-la-journee-du-20-septembre-2019-sur-les-disparus-de-la-guerre-d.html and proceedings at https://journals.openedition.org/ revdh/8447? file=1 (in French only).

23 Malika Rahal, historian, Institut d'histoire du temps présent (IHTP-CNRS), and Fabrice Riceputi, lecturer and historian, author of La bataille d'Einaudi, comment la mémoire du 17 octobre 1961 revint à la République, Le passager clandestin, 2015.

24 ANOM, 91/ 4 I 62, “Arrests, requests for investigations passed to military command".

25 From 1948 to 1964, IGAMEs were prefects of départements at the centre of military regions tasked with coordinating the action of the civilian and military authorities during periods of unrest.

26 For more information about this SLNA file, see: Riceputi, Fabrice. Histoire d'un fichier secret, la recherche des personnes enlevées par l'armée française à Alger en 1957. Available at http://1000autres.org/sample-page.

27 Harry Salem aka Henri Alleg (born on 20 July 1921 in London and died on 17 July 2013 in Paris), was the editor of the Alger Républicain newspaper, which was banned in 1955, and a member of the PCA. Detained on 12 June 1957, the day after Maurice Audin was arrested, he was also locked up and tortured. He later wrote an account of his ordeal, smuggling it out of prison via his lawyers. Published under the title La Question in February 1958, it was immediately banned, only to be reprinted in Switzerland with a preface by Jean-Paul Sartre. It was received with considerable acclaim.

28 A first list was published by Les Temps Modernes, no. 163, in September 1959.

29 French National Archives, Archives of the Commission for the Protection of Human Rights and Fundamental Freedoms (F/60/3124-F/60/3231).

30 Groups of European Algerians who, from the start of the war, staged armed attacks on the local population and, in early 1961, joined forces to create the Organisation de l'Armée Secrète - Secret Army Organization.

31 The Evian Accords were signed on 18 March 1962 and, on 22 March 1962, the French Government published two decrees, one (Decree No. 62-327) amnestying "offences committed during the Algerian uprising", in execution of one of the provisions of the accords - in $\mathbb{S}$ ) of Part 1 on the "Conditions for and guarantees of self-determination" - and the other (Decree No. 60-328, published in the Official Gazette on 23 March, p. 3144), amnestying "offences committed as part of law and order operations during the Algerian uprising before 20 March 1962", although this was not a specific requirement. 
32 Available at https://histoirecoloniale.net/Les-video-de-la-journee-du-20-septembre-2019-sur-les-disparus-de-la-guerre-d.html (in French only).

33 Following François Hollande's election as President, the order dated 1 February 2013 established a general exemption for the consultation of public archives relating to the disappearance of Maurice Audin. This was published in the Official Gazette on 23 February 2013, p. 3096 (available for consultation online in French at Légifrance).

34 Official order of 9 September 2019 on open access to archives regarding the disappearance of Maurice Audin. Available at www.legifrance.gouv.fr/affichTexte. do?cidTexte=JORFTEXT000039070402\&categorieLien=id.

35 As President Hollande had done on three earlier occasions: firstly, in 2013, with regard to the assassination of Maurice Audin; secondly, with regard to the December 1952 assassination of the Tunisian trade unionist Ferhat Hached; thirdly, in October 2012, over the massacre of Senegalese riflemen at Thiaroye in December 1944.

36 Decree 2019-1271 of 2 December 2019 on the conditions for classifying and protecting national defence secrecy. Available at www.legifrance.gouv.fr/eli/ decret/2019/12/2/PRMD1928053D/jo/texte.

37 Harkis: generic term for native Muslim Algerians who served as auxiliaries in the French Army during the Algerian War.

38 Anne Liskenne (2015) explains how the French administration dedicated resources to documenting the disappearance of Europeans and keeping their families informed.

39 This detailed database, covering only Europeans missing and presumed dead, was put online in 2004: www.diplomatie.gouv.fr/fr/archives-diplomatiques/sorienter-dans-les-fonds-et-collections/etat-civil-et-genealogie/article/recherchede-personnes-disparues-en-algerie-pendant-les-derniers-mois-de-la (in French).

40 The term "pieds-noirs" refers to French nationals born in Algeria and French nationals of other European origins who lived in French North Africa up until independence.

41 The office set up at the French National Archives in 2004 and acting as an intermediary for all those seeking to assert their rights (such as French Jews plundered or interned, and people wishing to obtain French nationality) could possibly handle this type of requests. (Editor's note).

42 This digital guide to the missing of the Algerian War lists archives according to the category of missing person and not to where the records are conserved. Available at https://francearchives.fr/actualite/223693824/.

43 Two amnesty laws were adopted in France, by virtue of which it is impossible to prosecute members of the armed forces for human rights violations perpetrated during the Algerian War. The first followed the Evian Accords and dates back to March 1962. This ruled out the possibility of prosecuting military personnel accused of violations during combat (and also amnestied Algerian independentists but not French nationals accused of providing support for the FLN, to whom amnesty was only extended in 1966). This law effectively prevented the terrorist actions of those in favour of pursuing the combat from escalating into Civil War in France. It is therefore part of the next chapter of the country's history and cannot be challenged in the same way as some Latin American amnesty laws. A second law came into force in 1968, granting full impunity to members of the French armed forces who had failed to obey the government's orders. In 1982, these two amnesty laws were further reinforced with the introduction of administrative measures. By contrast with South African Truth and Reconciliation process, where full disclosure on the part of those responsible for human rights violations under apartheid was the condition sine qua non for avoiding 
prosecution, these two amnesty laws and the 1982 measures officially granted impunity to perpetrators of violations and decreed that their crimes should be forgotten. Rather than persisting in denying the truth of the past, thereby leaving a gaping hole in the nation's memory, France would be well advised to seek inspiration from the concept of transitional justice which, according to French magistrate Louis Joinet in his Report to the United Nations in support of the combat against impunity for perpetrators of human rights violations, is part and parcel of "the right to know the truth and, its corollary, the duty to preserve memory" and to find specific ways of lifting the veil of silence and official forgetfulness cloaking this chapter of history, this having a detrimental effect on the country today.

\section{Bibliography}

Alonso, Maïa. 2017, Le rêve assassiné. Lyon: Editions Atlantis.

Branche, Raphaëlle. 2005, La guerre d'Algérie: Une histoire apaisée? Paris: Seuil.

Conan, Eric. 1998, Le procès Papon: Un journal d'audience. Paris: Gallimard.

Leprince, Chloé. 2019, Guerre d'Algérie: Quand le secret défense entrave la mémoire. Article published on 14 October, France Culture website. Available at www.franceculture.fr/histoire/guerre-dalgerie-quand-le-secret-defense-entrave-la-memoire.

Liskenne, Anne. 2015, "Les Français disparus en Algérie dans les archives du ministère des Affaires étrangères," La Gazette des Archives, vol. 239, pp. 21-30.

Mollier, Jean-Yves. 2018, "Hommage à Brigitte Laîné (1942-2018), une juste parmi les justes," Actualité du XIXe siècle, Journal on line of the Société d'histoire de la Révolution de 1848 et des révolutions du XIXe siècle, 19 November.

Riceputi, Fabrice. 2020, “Confronter les archives de l'État aux mémoires vives: le site de recherche de disparus 1000autres.org," Actes de la journée d'étude, "Les disparus de la guerre d'Algérie du fait des forces de l'ordre françaises: Vérité et Justice?” pp. 17-22. The CREDOF Website. Available at https://journals.openedition.org/revdh/8447? file $=1$.

Slitinski, Michel. 1983, L'affaire Papon. Paris: Editions Alain Moreau.

Thénault, Sylvie, rééd. 2004, Une drôle de justice: Les magistrats dans la guerre d'Algérie. Paris: La Découverte.

- 2013, “Justice et droit d'exception en guerre d'Algérie (1954-1962)," Les Cabiers de la Justice, vol. 2, no. 2, pp. 71, 81.

Vaïsse, Maurice. 2019, "Un historien face au secret des archives," 20 \& 21. Revue d'histoire, vol. 143, pp. 149-153.

Vergès, Jacques, Zavrian, Michel, and Courrege, Maurice. 1959, Les disparus, le "cahier vert”. Lausanne: La Cité-éditeur.

Veyssiere, Marion. 2019. "La communication des archives publiques en France. Le cadre législatif et réglementaire à l'épreuve de la pratique," 20ひ21, Revue d'histoire, vol. 142, pp. 141-149.

Vidal-Naquet, Pierre. 1972, La Raison d'État and La Torture dans la République. Paris: Minuit. 1998, Mémoires. 2. Le trouble et la lumière 1955-1998. Seuil: La Découverte. 


\title{
12 Truth, memory, and reconciliation in post- communist societies
}

\author{
The Romanian experience and \\ the Securitate archives
}

\author{
Marius Stan and Vladimir Tismaneanu
}

\section{Introduction}

Coming to terms with the past, confronting its legacies and burden, was the inevitable starting point for the new democracies of Eastern Europe. Thirty years after the fall of communism, both public intellectuals and scholars face a fundamental question: how can truth and justice be reinstated in a post-totalitarian community without the emergence of what Nietzsche called the "reek of cruelty"? In 2006, for the first time in Romania's contemporary history, the Presidential Commission for the Analysis of the Communist Dictatorship in Romania (PCACDR) rejected outright the practices of institutionalized forgetfulness and generated a national debate about long-denied and concealed moments of the communist past (including instances of collaboration, complicity, etc.). One of these authors (VT) had the honor of being appointed Chair of this state-body. He was one of the co-coordinators of its Final Report. ${ }^{1}$ Generally speaking, decommunization is, in its essence, a moral, political, and intellectual process. ${ }^{2}$ The PCACDR Report answered a fundamental necessity, characteristic of the post-authoritarian world, that of moral clarity. Only memory and history can furnish responsibility, justice, retribution, and repentance. Reconciliation and the healing of a nation plagued by the traumatic quagmire of Evil depend on the recognition and non-negotiability of human dignity as a primordial moral truth of the new society.

\section{Context}

In January 2007, Romania acceded to the European Union, a few years after having entered the North Atlantic Treaty Organization (NATO). This was a watershed in Romania's history, a significant moment in the history of Eastern Europe, and a test for the European Union's commitment to accepting problematic candidates as long as they have complied with the major accession requirements. In 2001, in a controversial article published in The New York Review of Books, historian Tony Judt argued 
that the real test for the European Union was Romania's accession, considering its pending structural problems (Judt, 2001). The piece generated anger among Romanian intellectuals and produced reactions, both pros and cons. Nevertheless, one cannot deny the nature of the difficulties with which Romania is faced still, among them that of an unmastered past. It is in this context that Romania's late decision to work through its communist past came about in a convoluted fashion. Once the process started in late 2005 and early 2006, it gathered a tremendous momentum and resulted in the first categorical state condemnation of the communist dictatorship as illegitimate and criminal.

It would be pertinent to look at and explain the coincidentia oppositorum of the efforts to "condemn the condemnation," the common front in attacking, slandering, and rejecting the Final Report created by latter-day radical left-wingers, fanatical nationalists, National-Stalinist nostalgics, and Christian Orthodox fundamentalists. ${ }^{3}$ It has always been crucial to identify the political and cultural forces that have infiltrated themselves into the subversion of the moral justice process in Romania. Going beyond various subjective stands, resentment, or personal vanities (from people such as the former president Ion Iliescu, who for most of his life was a Leninist apparatchik $)^{4}$, one needs to emphasize that this offensive against working through the past has structural motivations that are deeply rooted in the mentalities of communist times that have survived in the transitional Romanian political culture. The belated nature of Romania's decision to confront its communist totalitarian past was predominantly the consequence of obstinate opposition to such an undertaking from parties and personalities directly or indirectly linked to the ancien régime.

Very briefly, the elections of November and December 2004 resulted in the victory of an anticommunist coalition and the election of Traian Băsescu as the country's president. In spite of political rivalries and the disintegration of the initial government coalition, both the National Liberal and the Democratic Parties understood the importance of coming to terms with the past. Especially after January 2006, both the liberal prime minister, at the time, Călin Popescu-Tăriceanu (then head of the Liberal Party) and President Traian Băsescu (then linked to the Democratic Party) have championed decommunization. At the other end of the political spectrum, in an effort to boycott these initiatives, former president Ion Iliescu and other leaders of the Social Democratic Party (in many respects still dominated by former nomenklatura figures) allied themselves with the ultra-populist, jingoistic, and anti-Semitic Greater Romania Party, which was then headed by the notorious Corneliu Vadim Tudor, a former Ceauşescu sycophant. ${ }^{5}$ Around the same time, the condemnation of the communist dictatorship had become one of the most hotly debated political, ideological, and moral issues in contemporary Romania. Unlike Germany, where a parliamentary consensus (minus the radical left) allowed for the relatively peaceful activity of the Enquete Commission headed by former dissident pastor Reiner 
Eppelmann (analyzed in McAdams, 2001), the PCACDR was continuously under attack.

The inconsistent institutional backing for the PCACDR led some to argue that this Commission was only a presidential initiative, implicitly allowing them to paint it as a form of political partisanship. Such a characterization is mistaken: the Commission was mandated by the Romanian head of state, and it was the result of the successful pressure from below exercised by the most important organizations and representatives of Romania's democratic civil society. The PCACDR and its Final Report are the products of a collective civic effort officially endorsed by the Romanian state.

\section{The Romanian reckoning with the past in comparative perspective}

The PCACDR was the first such state body created in the countries of the former Soviet bloc. The only precedent could be found in unified Germany, where the Bundestag created, between 1992 and 1998, two successive Enquete Commissions that investigated the history of the SED (Socialist Unity Party) Dictatorship and its effects on German unity. At the end of the mandate of the second Enquete Commission, on the basis of its activity and practice, a foundation was established: the Stiftung zur Aufarbeitung der SED-Diktatur (June 5, 1998). ${ }^{6}$ The creation of the German commissions represents, however, a different situation under circumstances of unification, institutional absorption, and value transference on the West-East axis. There are nevertheless a series of similarities between the Enquete Commissions and the PCACDR, particularly in what concerned the mandates.

Both the Romanian and the German mandates understood the analysis of their communist pasts along the lines of the study of the structures of power and mechanisms of decision-making during the history of the regime; the functions and meaning of ideology, patterns of inclusion, and disciplinary practices within the state and society; the study of the legal and policing system; the role of the various churches during the various phases of state socialism; and finally, the role of dissidence, of civil disobedience, and, in Romania's case, of the 1989 revolution. Both in Romania and in Germany, the commissions were meant to provide evaluations related to problems of responsibility, guilt, and the continuity of political, cultural, social, and economic structures from the communist through post-communist periods. The overall purpose of both bodies was to establish the basis for what Avishai Margalit (2002) called an ethics of memory. The PCACDR activity was generally guided by Hannah Arendt's vision of responsibility and culpability: "What is unprecedented about totalitarianism is not only its ideological content, but the event itself of totalitarian domination" (Arendt, 1994, p. 405).

The difference between the German and Romanian commissions is that the Enquete Commissions of the SED Dictatorship and the subsequent 
foundation were created in a unified Germany with the massive support of the Bundestag, under circumstances of thorough delegitimization of the communist party and state, and in the context of a national consensus regarding the criminal nature of the Stasi. In contrast, in Romania, there was a flagrant absence of expiation, penance, or regret. Without such premises, any act of reconciliation draws dangerously close to whitewashing the past. Reconciliation is not and must not be bound to the premise of moral absolution. The transition from an illegitimate and criminal regime to democracy and a culture of human rights is, to paraphrase Charles VillaVicencio, a process in situ, it implies a series of compromises and negotiations. ${ }^{7}$ However, the act of healing a community must not be confused with moral consensus about the traumatic past. The historical justice and the shared memory provided by an Enquetekommission opens the path to post-transitional political realignment.

\section{Romania before the presidential commission}

The condemnation of the communist regime in Romania can be integrated, from a historical standpoint, into the space circumscribed by two factors that marked the post-1989 period. On one hand, Ion Iliescu, who, during his three mandates (1990-1992, 1992-1996, and 2000-2004) practiced what Peter Schneider coined for East Germany as a "double zombification" (Schneider, 1991): the two totalitarian experiences that plagued Romania's second half of the 20th century officially were "another country" after 1989. This was also a regrettable characteristic for the Democratic Convention during President Emil Constantinescu's administration from 1997 to 2000. Only after his own scandalous comments on the Holocaust in Romania that provoked a strong reaction in both diplomatic and international academic circles did Ion Iliescu create, in 2004, the International Commission on the Holocaust $(\mathrm{ICHR})^{8}$ in Romania, chaired by celebrated writer and Nobel Peace Prize laureate Elie Wiesel. The objective of this "mis-memory" of the totalitarian experience in the country was indeed the fuel of the legitimization discourses of the post-communist political establishment, of the "original democracy" designed by Iliescu and his acolytes in the first postcommunist years.

On the other hand, there were the constant attempts from the civil society to speed up the process of decommunization. The latter is defined by several original movements: the Timişoara proclamation in March 1990 that advocated lustration and the June 1990 student protest movements spearheaded by the Civic Alliance. Also encompassed within this framework are various attempts to rehabilitate certain periods of Romanian communism, along with campaigns aimed at recycling aspects of the country's authoritarian past (for example, the numerous initiatives to "restore the name" of pro-Nazi Marshal Ion Antonescu or to sanitize the murderous history of the fascist Iron Guard) $)^{9}$. In contrast, there 
were attempts at a "memory regime," that is, an effort to recuperate "a shattered past"(Jarausch and Geyer, 2003), in addition to movements that demanded other sorts of clarifications - particularly legal ones on the basis of the gradual opening of the Securitate archives and of other institutions that had a crucial role in the functioning and reproduction of the regime - and obtaining moral and material compensations for suffering inflicted by the 20th-century totalitarian experience in Romania. The essential obstacle to any democratic endeavor to work through the communist past lies in the fact that even though knowledge of the truth is gradually developed, it does not translate into an officially sanctioned acknowledgment of its history (Rigby, 2001, p. 82). In other words, institutionalized amnesia could be fully overcome only by an institutionalized memory of the communist dictatorship.

\section{The birth of a truth commission}

In April 2006, convinced by now of the urgent necessity of such an initiative, President Băsescu decided to create the PCACDR. His position at the time, and during the entire period of decommunization, proves the importance of political will and determination in the attempt to initiate and sustain a potentially centrifugal endeavor. President Băsescu entrusted Vladimir Tismaneanu with selecting the members of the commission. In so doing, the latter took into account the scholarly competence and moral credibility of the people invited to join this body. Among the commission members figured well-known historians, social scientists, civil society personalities, former political prisoners, former dissidents, and major figures of the democratic exile. President Băsescu charged the commission with the task of producing a rigorous and coherent document that would examine the main institutions, methods, and personalities that made possible the crimes and abuses of the communist regime. In addition to its academic tasks, the work of the commission was meant to pass moral judgment on the defunct dictatorship and invite a reckoning with the past through a painful, albeit inevitable, acknowledgement of its crimes against humanity and other forms of repression. This was a revolutionary step in Romanian postcommunist politics: neither ex-communist president Ion Iliescu nor anticommunist president Emil Constantinescu had engaged in such a potentially explosive undertaking. The Romanian case seems to validate Michael Ignatieff's assertion that

leaders can have an enormous impact on the mysterious process by which individuals come to terms with the painfulness of their societies' past. Leaders give their societies permission to say the unsayable, to think the unthinkable, to rise to gestures of reconciliation that people, individually, cannot imagine.

(Ignatieff, 1998, p. 188. See also Digeser, 2001) 
By creating the PCACDR, the Romanian President did institutionalize a fundamental tool of transitional justice despite its non-judicial truth-seeking nature.

\section{Reactions to the condemnation and political rearrangements after 2007}

The project and activities of the PCACDR benefited from the previous experience of the International Commission on the Holocaust (ICHR) in Romania. The main difference between the two endeavors was that the proceedings of the ICHR could not be perceived, as in the PCACDR's case, as a direct threat or involving a personal stake in contemporary society and politics, because the three historical groups involved in the Holocaust (the victims, the perpetrators, and the bystanders) had mostly disappeared. As far as the communist past is concerned, many of the perpetrators, victims, and witnesses of or by-standers to the regime's crimes were and still are alive, and sometimes involved in societal dynamics (some of them even held seats in the Romanian parliament). The moment on December 18, 2006, when exponents of the neo-Communist left and ultra-nationalist right booed President Băsescu's delivery of the findings of the PCACDR, demonstrated that a genuine democracy cannot function properly in the absence of historical consciousness. An authentic democratic community cannot be built on the denial of past crimes, abuses, and atrocities. The past is not another country. It cannot be wished away - the more that is attempted, the more we witness the return of repressed memories (for example, consider the recurring efforts to prosecute former Mexican president Luis Echeverría for his involvement in the bloody repression of student demonstrations in 1968, "The Tlatelolco Massacre," and in 1971, "The Corpus Christi Massacre"). For the first time in post-1989 Romania, the PCACDR rejected outright the practices of institutionalized amnesia and generated a national conversation about long-denied and concealed moments of the past (including instances of collaboration and complicity) (Tanasoiu, 2007).

The PCACDR aimed at a synthesis between understanding the traumatic history through a methodology that presupposes distance from the surveyed subject and empathizing with the people who suffered from the crimes and abuses of the dictatorship. The commission pursued a reconstruction of the past along the dichotomy of distance-empathy, focusing upon both general and individual aspects of the past. The Final Report's intentionality lies in the facts, ${ }^{10}$ in the more or less familiar places of Romania's communist history. The PCACDR first identified victims, regardless of their political colors, for one cannot argue that one is against torture for the left while ignoring such practices when it comes to the right. The militants of the far right should have been punished on a legal basis, but this was not the case for the trials put forth by the Romanian Communist Party (RCP). The communists simply shattered any notion of the rule of law. The Final Report 
identifies the nature of abuses and its victims, though it does not leave aside the ideological context of the times. For the PCACDR, the communist regime represented the opposite of rule of law, an Unrechtsstaat.

The PCACDR was "a state, public history lesson" during which the "truth" about the communist totalitarian experience was "officially proclaimed and publicly exposed," that is, acknowledged. It was an exercise of "sovereignty over memory," 11 an attempt to break with the self-serving historical narratives of the Ceauşescu era and expose the role of the Romanian state in the exercise of direct and indirect terror against the population for more than four decades.

\section{The commission and the democratization of the archives}

Created in 1999 in Bucharest ${ }^{12}$ and directly controlled by the Romanian Parliament, the National Council for the Study of the Securitate Archives (CNSAS) did not effectively start functioning until $2007,{ }^{13}$ mostly because of the lack of political will. Simply put, "acting at the national level, [the CNSAS] was the result of a long lobby for the declassification of the Securitate's files" (Mitroiu, 2016, p. 3). In this respect, the condemnation of the communist regime as illegitimate and criminal by the President Traian Băsescu in December 2006 opened up a new era for the Romanian archives (the CNSAS included). Until that moment, the employees of this institution had been very low profile in the public domain as they were supposed to investigate and reveal the past of former Securitate personnel without actually seeing their files. It was only via President Traian Băsescu's strong political commitment toward decommunization that the Romanian Intelligence Service started to deliver more and more files to the lawful keeper, CNSAS. In other words, between 1999 and 2006, the CNSAS had been able to access less than $1 \%$ of the former Securitate archives (less than 10,000 files). Then, through a Supreme Council of National Defense political decision, a massive process of declassification started and the heir to the former Securitate, SRI, ${ }^{14}$ had transferred up to 20 kilometers of files, meaning 2.3 million volumes. The transfer process continued for a few years afterward. Mention should be made also of the tens of thousands of files which had already been destroyed during the 1989 revolution and the 1990 "Berevoieşti affair."

In theory, the 1999 law for the establishment of the CNSAS gave unrestricted access to the Securitate files, apart from those relating to national security issues. In practice, however, the files remained under SRI control. After 2008, and to the shock of many, including foreign citizens in communist Romania, the access to personal files by the former Securitate "almost felt as if you obtained your FBI file and found documents about yourself signed by J. Edgar Hoover" (Verdery, 2012, p. 16; see also Verdery, 2018). It proved yet again that these files contain essential data linking top-ranking officials in the communist pyramid of power to political police activities. Furthermore, high-profile files can offer a glimpse into the nature of top 
party struggles between 1945 and 1989. The presidential commission had tried to shed light on issues pertaining to the specific responsibilities of various communist magnates. Their personal records generally contain autobiographies, notes given by former collaborators, useful information on party sanctions (and, in some cases, their annulment). It would be almost impossible to retrace conclusively the history of the struggle between different nuclei of power in the communist party during WWII without open access to such files.

The members and experts of the PCACDR had been able to study the documents in the Archive of the Department of Military Courts, but the archives of the military courts in other cities (Cluj and Timişoara) had been impossible to access. Some of the members and experts of the commission had worked in the Military Archives (MApN), others in the archives of the various divisions of the Central Committee of the Romanian Communist Party, the archives of the Union of Communist Youth (UTC), and the Central Committee's chancellery office. In many cases, contrary to what the press had been informed, the members of the commission were not the first to see the documents (there are records to confirm early "visitors" in the archives at a time when they seemed mostly closed to common citizens - in the 1990s and the early 2000s).

Perhaps the most daunting obstacle to the Commission's work was obtaining access to archives from Communist times (of the Central Committee, of ministries, of various institutions directly involved in the functioning of the regime, and so on). While the then president was very optimistic at the start of the project, he soon discovered its challenges. The PCACDR worked under very difficult circumstances - the archives were locked, large sectors of society were apathetic, and the intellectuals remained divided. But the Commission eventually succeeded, which would not have happened without president Băsescu.

These details are relevant for how the reading of the archives of the former Securitate ${ }^{15}$ of the communist party, and various ministries affected the preliminary structure of the Final Report of the PCACDR. For instance, the activity of the Commission had been met with a lot of polite resistance at the archives of the Health Ministry, a highly important source for documenting gross violations of human rights, medical abuses, and other convoluted phenomena tied to Ceauşescu's demographic policies (particularly his Decree 770/ 1966, which outlawed abortion). Moreover, outside Bucharest, local technical details seemed to be, at times, insurmountable. There simply was not enough transparency and access to the archives before the activity of the PCACDR. In this respect, the pioneering work of the Commission with regard to the democratization of the Romanian archives should be emphasized.

One of the Final Report's significant conclusions was that continuity existed between the first and second stages of Romanian Communism: this shattered the previous historiographical consensus that the latter Ceauşescu 
dictatorship was fully nationalist while the earlier Dej regime was not. ${ }^{16}$ This assertion enraged the "old historians," meaning the ex-Communist historians. They countered the report's conclusion by claiming that Ceauşescu condemned the Soviet invasion of Czechoslovakia, that he was anti-Soviet, and that he had supposedly represented the country's national interest in the most prominent circles and arenas of the Cold War order. ${ }^{17}$ Basically, they peddled nothing but a recycled form of Ceauşescu's claims about the legitimacy of his own rule. To understand the reasons for these historians' reaction, one has to look into the impact of the Presidential Commission on their status. Cristian Vasile, the scientific secretary of the PCACDR, pointed out that the democratization of the local archives was "a powerful blow against the barons of Romanian historiography" (Vasile, 2011). These barons were mainly members of the historiographical establishment (high-profile members of the Romanian Academy and/or of its Institutes of History), who had made their names during the Communist period. After 1989, they hardly altered their nation-centric approach and often whitewashed their involvement in the self-presentation of the regime. ${ }^{18}$ As another historian pointed out, "Historiography itself becomes multileveled: from institutional history to biographies, from history of particular policies to the study of the production of knowledge/identity, from social history to history of everyday life, from high politics to regional, local, and microhistories" (Iacob, 2014, p. 52). From this point of view, the procurement of complete and unhindered access to the archives of the Communist regime in Romania had been of paramount importance. ${ }^{19}$

\section{Instead of conclusions}

The year 2006 was pivotal not only because of the condemnation of the Communist regime but also because more than 1,300,000 files of the Securitate were transferred into the archive of the CNSAS. The inevitable question is, why 2006? We suggest that these events occurred that year because of political will and the mobilization of civil society on this issue. Decommunization in Romania had been delayed because the former Securitate and nomenklatura members had been prospering for the first 15 years following the 1989 revolution. But, by 2006, there emerged a critical mass of support for the creation of a truth commission, which exerted considerable pressure on the president. This public engagement, most obvious in a series of public interventions from notable intellectuals, resulted in the establishment at the beginning of 2006 of the Institute for the Investigation of Communist Crimes in Romania (IICCR) led by historians Marius Oprea and Stejărel Olaru, and in the increasingly strong civic reactions to the decisions of the CNSAS to make its files public (Horne, 2009, pp. 344-376; Stan, 2009a, 2009b, pp. 1-13).

The effort of condemning the Communist dictatorship was (at least) tridimensional, existing in the realms of epistemology, legality (with regard 
to both juridical and legislative initiatives), and memorialization. From an epistemic point of view, numerous volumes, memoirs, documents, diaries, and historical, sociological, economic, philosophical, literary, and political science surveys have been published in the years since the condemnation. Most of these editorial projects were the collective works of government institutions such as the CNSAS, the National Archives, the Romanian Diplomatic Institute, or the ICCMER (the present-day heir to IICCR). From a legal perspective, some property restitution cases (in connection to the confiscations perpetrated by the Communist regime) have been resolved. Likewise, there have been juridical verdicts annulling prison, concentration camps, and death sentences from the 1950s. It is obvious that it takes much more effort and initiatives to complete such a total righting of the past, endeavors made all the more difficult because the heirs of the former nomenklatura have no interest in such an enterprise.

We have outlined the labyrinthine story going from the initial refusal to allow public access to any archives from the communist era to the opening of these archives to researchers, journalists, former victims, etc. Postcommunist democracies need to root themselves in an unsparingly honest knowledge of the past, both with its heroic and its inglorious moments. The Securitate archives show that many people collaborated with the regime, yet many refused to do so. They document the human rights abuses and provide strong arguments against the attempts to exonerate the perpetrators of the crimes against humanity. In this respect, although somewhat of a laggard in addressing these disturbing issues, Romania has succeeded in providing a possible model of what a truth commission can do in deconstructing stubborn mythologies and overcoming persistent negationist endeavors.

\section{Notes}

1 For details regarding the activity of the Presidential Commission, its meanings in local and European context, and the aftermath of the condemnation, see Tismaneanu, Vladimir and Stan, Marius, Romania Confronts Its Communist Past: Democracy, Memory, and Moral Justice. Cambridge: Cambridge University Press. The volume also reflects the head of the Commission's recollections (VT's) regarding the establishment of this body, the sometimes fastidious selection of its members and experts, the achievements as well as shortcomings.

2 Decommunization, like post-1945 de-Nazification in Germany, is both a destructive and a constructive endeavor. On the one hand, it abolishes authoritarian institutions; on the other hand, it means the establishment and the consolidation of a political order respectful of civic rights. Despite all their differences, and there were many, communism and fascism shared the same hostility to liberalism, middle-class values, individual autonomy, and the state of law. Decommunization, like de-Nazification, is a mental (cultural, psychological) process as much as a political, economic, and legal one.

3 For an examination of the reactions from 2009 to 2013, see Iacob, Bogdan C. 2014, "The Romanian Communist Past and the Entrapment of Polemics," in: Tismaneanu, Vladimir and Iacob, Bogdan C. (eds.), Remembrance, History, and 
Justice: Dealing with the Past in Democratic Societies. Budapest: Central European University Press, pp. 417-474.

4 Ion Iliescu (b. 1930), who had been the Communist Youth Union first secretary and youth minister during 1967-1971, supervised campaigns to neutralize rebellious attitudes among the young writers, while students who raised their voices for freedom, especially in 1968, were promptly reprimanded with his blessing. The same young Iliescu had accompanied Ceauşescu in his decisive 1971 Asia trip, to China and North Korea (see Kotkin, Stephen. 2009, Uncivil Society: 1989 and the Implosion of the Communist Establishment. New York: Modern Library, p. 74, note 13. In his 2001 NYRB article (see endnote 3), Tony Judt wrote that "both [Corneliu Vadim] Tudor and [Ion] Iliescu have [had, in CVT's case] deep roots in pre-1989 Romanian politics. Tudor was Nicolae Ceauşescu's best-known literary sycophant, writing odes to his leader's glory before making the easy switch from national communism to ultranationalism and founding his Greater Romania Party in 1991 with émigré cash. Ion Iliescu is one of a number of senior Communists who turned against Ceauşescu and manipulated a suspiciously stage-managed revolution to their own advantage."

5 After 1989, "former supporters of Ceauşescu, including a number of notorious sycophants, have adopted his nationalist postures and given them a more extreme form. [S]ycophants of Ceauşescu, notably those associated with the former weekly Săptămâna, have become the most ardent advocates of extreme nationalism in an attempt to deflect attention from their part in bolstering the former dictator": Deletant, Dennis. 1995, "Epilogue," in: Ceauşescu and the Securitate: Coercion and Dissent in Romania, 1965-1989. London: Routledge, pp. 386-404; for a brief portrait of Corneliu Vadim Tudor, see footnote 16 of the same Epilogue.

6 See the full-text of the establishing Act passed by the German Bundestag in June 1998. Available at www.bundesstiftung-aufarbeitung.de/headline-1081. html.

7 In this perspective, transition is the "result of exposure, talks and what are more often than not messy negotiations. The outcome is almost inevitably a hybrid of mechanisms of justice, politics and coexistence that emerge from interim and experimental initiatives designed to promote nation-building." See Villa-Vicencio, Charles, and Doxtader, Erik, eds. 2003, The Provocations of Amnesty: Memory, Justice, and Impunity. Trenton: Africa World Press, p. 31.

8 See the Final Report of the International Commission on the Holocaust in Romania. Available at www.yadvashem.org/docs/international-commission-onromania-holocaust.html.

9 See Vladimir Tismaneanu's Romanian language volume Spectrele Europei Centrale. Bucuresti: Polirom, 2001, where the author discusses the interesting process of recycling (neo/proto/crypto) fascism by means of integrating it into the identitarian discourse legitimizing the communist regime. In the "Lessons of the 20th Century" chapter, VT argues that "the Ceauşescu regime was, at its most basic level, a very interesting mix that brought together both the legacy of militarist authoritarianism from the 1941-1944 period, which was celebrated in myriad ways, and the degraded mystic inspired by the extreme-right, which was grafted upon the institutional body of Romanian Stalinism” (pp. 246-247).

10 Moses, A. D. 1998, "Structure and Agency in the Holocaust: Daniel J. Goldhagen and His Critics," History and Theory, vol. 37, no. 2, pp. 194-219, 218, May. Dominick LaCapra similarly points to the distance-empathy synthesis, as a valid method of approaching recent history, in his argument for reconstruction and electivity on the basis of fact within a democratic value system: "A reckoning with the past in keeping with democratic values requires the ability - or at least 
the attempt - to read scars and to affirm only what deserves affirmation as one turn the lamp of critical reflection on oneself and one's own." LaCapra, Dominick. 1992, "Representing the Holocaust: Reflections on the Historians' Debate," in: Friedländer, Saul (ed.), Probing the Limits of Representation: Nazism and the Final Solution. Cambridge: Harvard University Press, pp. 108-127. See also LaCapra, Dominick. 1998, "Revisiting the Historians' Debate - Mourning and Genocide," History and Memory, vol. 9, no. 1-2, pp. 80-112.

11 We are employing here the concepts developed by Timothy Garton Ash and Timothy Snyder in Garton Ash, Timothy, "Trials, Purges and History Lessons: Treating a Difficult Past in Post-Communist Europe" and Snyder, Timothy. 2002, "Memory of Sovereignty and Sovereignty over Memory: Poland, Lithuania and Ukraine, 1939-1999," in: Müller, Jan-Werner (ed.), Memory and Power in Post-War Europe: Studies in the Presence of the Past. Cambridge: Cambridge University Press.

12 Law No. 187, 7 December 1999. Available at www.cnsas.ro/cadrul_legal.html, accessed 1 March 2019.

13 "CNSAS was to be led by a council of eleven representatives of the leading political parties. At best, this arrangement signified democratic pluralism; at its worst, it meant that the council's activity was often nearly paralyzed by the wide differences among its leaders, some of whom represented parties which fought to close CNSAS and all access to the archives." Vatulescu, Cristina. 2010, "Arresting Biographies: The Personal File in the Soviet Union and Romania," in: Police Aesthetics: Literature, Film, and the Secret Police in Soviet Times. Stanford: Stanford University Press, p. 28.

14 "Following the disbandment of the Securitate the internal security services were restructured and split up, resulting in the creation of nine new security and intelligence services." SRI was one of them. "These services were each formed around the nucleus of a former Securitate directorate or unit. Thus the SRI initially drew its personnel from the directorate of internal security" (Deletant, Dennis. 2001, "Ghosts from the Past: Successors to the Securitate in Post-Communist Romania," in: Light, Duncan, and Phinnemore, David (eds.), Post-Communist Romania: Coming to Terms with Transition. New York: Palgrave Macmillan, pp. 41-42).

15 For details regarding the historiography of the problem and the functioning of the former Securitate, see Caietele CNSAS, Year 1, No. 1/2008.

16 "In the popular imagination, and in the orthodox narratives of several prominent historians and social commentators, the Dej period [1948-1965] was characterized by a slavish obedience to the Soviet Union and mass repression, while Ceauşescu [1965-1989], for all his later faults, sought to break with the 'Cominternist' past and place Romania squarely on its own course. The commission argues for a fundamental connection between these two periods: The use of terror and incarceration continued, albeit in more variegated forms, across the Dej - Ceauşescu transition. The rhetoric of socialist internationalism was mixed with a reinvigorated form of national exclusivism after the mid-1960s, but overall there was no clear break between a 'Stalinist' brand of Romanian communism and its 'national' variety later on." See King, Charles. 2007, "Remembering Romanian Communism," Slavic Review, vol. 66, no. 4, p. 719, Winter.

17 On Romanian historiography's clashes with political power, see Zavatti, Francesco. 2013, “'Historiography Has Been a Minefield' - A Conversation with Vladimir Tismaneanu," Baltic Worlds, p. 13, April: "The majority of the older historians had collaborated with the Communist regime. (David Prodan, Lucian Boia, Şerban Rădulescu-Zoner, Alexandru Zub, and Şerban Papacostea were rather the exception.) Some did so enthusiastically, others reluctantly. Some became Securitate informers. Altogether, [they had] a pretty depressing record. 
Initially, immediately after the regime's collapse, there was an effort to exorcize the demons of the past and to repent for the abdication imposed by the regime. However, with support from Ion Iliescu, the nationalist school resurrected quite swiftly and took over the main institutions, including the archives. One influential person was Professor Ioan Scurtu [b. 1940], Iliescu's history advisor and one of the most adamant supporters of the national Stalinist paradigm. These people perceived the Final Report as a personal offence and responded accordingly: with slander, innuendo, and threats." (VT).

18 For example, the CNSAS published the details of historian Dinu C. Giurescu's involvement and dealings with the Romanian secret police. See "Dinu Giurescu şi Securitatea," vol. 22, 28 January 2014.

19 As Monica Ciobanu put it, "access to archives, documents and files provides researchers from these agencies [The National Archives, IICCMER, CNSAS] new opportunities for exploring pre-1989 history in a systematic manner and on the basis of official sources. This represents a departure from an approach to the past through memoirs, diaries and biographies of victims or of those who were influential participants in the socialist system." See Ciobanu, Monica. 2011, "Rewriting and Remembering Romanian Communism: Some Controversial Issues," Nationalities Papers, vol. 39, no. 2, p. 206, March.

\section{Bibliography}

Arendt, Hannah. 1994, Essays in Understanding 1930-1954. New York: Harcourt Brace.

Digeser, Peter. 2001, Political Forgiveness. Ithaca, NY: Cornell University Press.

Horne, Cynthia M. 2009, "Late Lustration Programmes in Romania and Poland: Supporting or Undermining Democratic Transitions?," Democratization, vol. 16, no. 2, April.

Iacob, Bogdan C. 2014, "The Communist Regime in Romania: Interpretation or Condemnation?," Südosteuropa-Mitteilungen, vol. 54, no. 2.

Ignatieff, Michael. 1998, The Warrior's Honour: Ethnic War and the Modern Conscience. London: Chatto \& Windus.

Jarausch, Konrad H., and Geyer, Michael. 2003, Shattered Past: Reconstructing German Histories. Princeton, NJ: Princeton University Press.

Judt, Tony. 2001, "Romania: Bottom of the Heap," The New York Review of Books, vol. 48, 1 November.

Margalit, Avishai. 2002, The Ethics of Memory. Cambridge, MA: Harvard University Press.

McAdams, J. 2001, Judging the Past in Unified Germany. New York: Cambridge University Press.

Mitroiu, Simona. 2016, "Recuperative Memory in Romanian Post-Communist Society," Nationalities Papers, vol. 44, no. 5, June.

Rigby, Andrew. 2001, Justice and Reconciliation: After the Violence. Boulder, CO: Lynn Rienner.

Schneider, Peter. 1991, The German Comedy: Scenes of Life After the Wall. New York: Farrar, Straus and Giroux.

Stan, Lavinia, ed. 2009a, Transitional Justice in Eastern Europe and the Former Soviet Union: Reckoning with the Communist Past. New York: Routledge.

- 2009b, "Truth Commissions in Post-Communism: The Overlooked Solution?," Open Political Science Journal, vol. 2. 


\section{Marius Stan and Vladimir Tismaneanu}

Tanasoiu, Cosmina. 2007, "The Tismaneanu Report: Romania Revisits Its Past," Problems of Post-Communism, pp. 60-69, July-August.

Vasile, Cristian. 2011, Cinci ani de la Raportul final/Five Years Since the Final Report, December 17. Available at www.contributors.ro/cultura/cinci-ani-de-la-raportulfinal-despre-o-condamnare-\%E2\% 80\% 93-nu-doar-simbolica- \%E2\% 80\%93-aregimului-comunist, accessed 22 February 2019.

Verdery, Katherine. 2012, "Observers Observed an Anthropologist Under Surveillance," Anthropology Now, vol. 4, no. 2, September.

- 2018, My Life as a Spy: Investigations in a Secret Police File. Durham, NC: Duke University Press. 
Latin America 
$\because$ Taylor \& Francis Taylor \& Francis Group http://taylorandfrancis.com 


\title{
13 Archives for memory and justice in Colombia after the Peace Agreements
}

\author{
Ramon Alberch i Fugueras
}

\section{The historical and political contexts}

Putting an armed conflict like the Colombian case into context in a few lines is a complicated task - a conflict that has endured more than 50 years under a democratic state and which has taken on multiple forms of victimisation by a number of different protagonists (guerrilla, paramilitary and self-defence groups, the armed forces, etc.). This multiplicity of players with conflicting interests has led some stakeholders to deny the existence of an armed conflict which is clearly a response to structural causes and manifest inequality. As Gonzalo Sánchez points out: many people would like to continue seeing the current violence as simply an expression of crime or banditry, and not as a manifestation of fundamental problems in the make-up of our political and social order (Centro Nacional de Memoria Histórica, 2013, p. 13). ${ }^{1}$

The causes of the conflict are many and complex; the most relevant ones being that the appropriation, use and possession of land have been the driving force behind the origin and persistence of the armed conflict, added to which are other problems: drug trafficking, mining and energy supply, agro-industrial models and criminal alliances between paramilitary groups, politicians, public servants, local business and financial elites, and drug traffickers (Centro Nacional de Memoria Histórica, 2013, p. 21). This violence has undergone notable transformations, both in its forms of victimisation and its geographical location.

Furthermore, a certain democratic precariousness has been evident in the prioritisation of repressive and military options for tackling a situation of conflict due to corruption, impunity, racism, poverty, and exclusion. The political pact between liberals and conservatives to preserve a two-party model - the "National Front" (1958-1974), and the unconditional adherence to the so-called National Security Doctrine which reflected a notorious fear of communism and assumptions of a phantasmagorical "internal enemy", has prevented a consensus-based solution to the internal armed conflict. At the same time, the few peace initiatives undertaken in the 1980s and 1990s failed to succeed in taking root or facilitating any de-escalation of the conflict. 


\section{Ramon Alberch i Fugueras}

The study "Basta ya!" (Enough Is Enough!) produced by the Group for the Historical Memory (Grupo de Memoria Histórica) proposes a division of the conflict into phases reflecting the fact that the lethal nature of the violence has been neither homogeneous nor constant. In the following, we summarise these phases:

1958-1964: a decreasing trend. Transition from bipartisan to subversive violence

1965-1981: low level violence, fairly stable in its degree. Guerrilla incursions and their confrontation with the state ${ }^{2}$

1982-1995: growth in violence marked by the expansion of guerrilla groups, the incursions of paramilitary groups, the spread of drug trafficking and the crisis of state

1996-2002: an explosive trend. Military strengthening of the guerrillas, expansion of the paramilitary groups, reconfiguration of drug trafficking, and the economic crisis and crisis of state

2003-present (2016): a decreasing trend. Military initiative taken by the state, withdrawal of guerrilla groups and partial demobilisation of the paramilitary groups (Centro Nacional de Memoria Histórica, 2013, p. 33)

On a general level, as violence is principally based in the rural environment, occurring daily and focused on anonymous individuals, a certain proportion of the population in the big cities has not felt affected or involved (through a sad mixture of passivity and indifference), living in a situation of apparent peace and prosperity, with a comfortable perception of political and economic stability. The impact of this frequent, low-intensity violence, which does not reach the national level but has a high impact at the local level, reveals a level of numbers which is truly terrifying.

Between 1958 and 2012, the armed conflict caused the death of at least 220,000 people, a figure that is currently being revised upwards by the Single Registry of Victims (RUV: Registro Único de Víctimas) implemented by Act 1448/2011 on victims and land restitution. To this figure should be added those killed in war (40,787 combatants between 1958 and 2012), as well as "non-lethal" violence with serious consequences: 25,007 missing persons, 1,754 victims of sexual violence, 6,421 children and adolescents recruited by armed groups, 27,023 kidnapped between 1970 and 2010, 10,440 victims for landmines between 1982 and 2012 (Centro Nacional de Memoria Histórica - Fundación Prolongar, 2017), ${ }^{3}$ and 4,744,046 internally displaced persons (which could be increased to around 5.6 million if we add the 819,510 displaced persons between 1985 and 1995, according to data provided by CODHES, the Consultancy for Human Rights and Displacement, i.e. almost $15 \%$ of the total Colombian population; or almost 7 million in recent figures provided by the Unit for Comprehensive Care and Reparation of Victims, 2019). 
And this violence, according to the National Observatory for the Memory and Armed Conflict (ONMC: Observatorio Nacional de Memoria y Conflicto armado), has taken ten different forms: warlike action, attacks on populations, selective assassinations, massacres, terrorist attacks, sexual violence, kidnappings, forced disappearance, recruitment of minors and adolescents, and damage to private property. The 1991 Political Constitution enshrines peace as a right and allows for the opening of avenues to broaden political involvement. Finally, with the signing of the Final Agreement to end the conflict and build a stable and lasting peace, on 24 November 2016, between the national government and the FARC-EP guerrillas, there are now great expectations of a definitive end to the armed conflict, although not without difficulties in the face of the negative reactions of some groups involved in the violence (notably the National Liberation Army (ELN) and a small group of former members of the FARC).

\section{The legal framework}

The political will to put an end to the armed conflict has produced a plethora of regulations which have highlighted the relevance of the institutions in charge of engineering the process of transitional justice, ${ }^{4}$ and which fully comprehend the importance of the organization and custody of, and access to, public and private archives as indispensable tools to achieve justice, reparation, the guarantee of non-repetition, and which uphold the principle of truth.

For the sake of clarity, we shall limit ourselves to listing the most relevant laws and, especially, those that create transitional bodies of justice that have the task of drafting, processing, and utilising a great variety of documents intensively in order to achieve their goals. It should be noted that with the acceptance of the concept of transitional justice, it is assumed that the criterion should prevail that war crimes and crimes against humanity cannot go unpunished, and the aim is to satisfy the minimum requirements laid down by courts and international bodies, in addition to reiterating the need to give the victims of the conflict clear satisfaction in three aspects: knowledge of what happened - for the fulfilment of their purposes (the truth); that there is a minimum acceptable punishment (justice); and that there are forms of compensation for the victims, whether moral or material (reparations) (Meto, 2016, pp. 319-337). ${ }^{5}$

The regulations drawn up in Colombia in recent years are abundant and complex. ${ }^{6}$ Thus, the National Archives (AGN, Archivo General de la Nación), in addition to Act 594/2000 on archives, on which the Colombian archival system is based, has also produced various circulars and agreements referring to the identification, location, organization and protection of archives relating to the armed conflict. ${ }^{7}$ With regard to State legislation, worthy of note is Law 975/2005 on Justice and Peace; Law 1424/2010 which lays down transitional justice provisions to guarantee truth, justice, 
and reparations for the victims of demobilised members of organised groups outside the law and grant legal benefits; as well as Law 1448/2011 on victims and land restitution which provides a new approach to tackling the conflict based on the trilogy of Land, Truth, and Reparations.

This last law, regulated in Decree 4800/2001, in Article 189 orders the creation of a Special Registry of Archives of the Human Rights and Historical Memory Program in coordination with National Centre for Historical Memory (CNMH, Centro Nacional de Memoria Histórica) and the AGN, as well as orders both entities that prepare an archival policy protocol in DH and IHL and, finally, Article 191 prescribes that the AGN must create an internal working group, called "Group of Ethnic Archives and Human Rights". ${ }^{8}$

The creation of the CNMH resulted from the aforementioned Law 1448/2011, and has been further developed by decrees. ${ }^{9}$ The Legal Branch has also produced specific agreements for archive management with regard to drafting policies, setting up archive committees and laying down principles aimed at regulating document management. ${ }^{10}$ Finally, with the signing of the Peace Agreement, ${ }^{11}$ the Comprehensive System of Truth, Justice, Reparations and Non-Repetition or SIVJRNR (Sistema Integral de Verdad, Justicia, Reparación y No Repetición) was created, which develops a group of bodies in which the use of documents and archives acquire a central role. We refer especially to the Commission for the Clarification of the Truth: the CEV; the Special Unit for the Search of Missing Persons, the UBPD; and the Special Jurisdiction for Peace, the JEP.

It should be noted that the abundance of laws and, especially, the creation of numerous bodies involved in the resolution of the armed conflict has given rise to a number of dissenting voices, such as that of Winifred Tate (2007), who denounces "a fragmented, overlapping and confusing bureaucratic proliferation of state bodies with some incidence and responsibility for human rights, a real maze that forces one to go through several offices without result".

\section{The central nature of the archives}

Although in any process of political transition archives play a decisive role in the achievement of the values of truth, justice, and reparation, the Colombian case contains a series of particular characteristics which make it a truly exceptional case. In general, theoretical reflections of international scope which propose policies for human rights archives refer mainly to processes of political transition from a totalitarian regime to a democracy. Consequently, only a proportion of these reflections become inputs for the Colombian case, which constitutes a unique "model" in the international sphere, given that the armed conflict has arisen in a political context characterised by the consolidation of free elections and, therefore, also consecutive democratic governments. Or, to put it another way, the policies on human rights 
archives formulated in Europe and North America are reflected in the creation of a model which has become a "classic" one, based on the most recent experiences, and which has overwhelmingly taken shape in the more or less orderly transition from a totalitarian regime to a democracy (Latin America, especially the southern cone, southern Europe, and all the eastern European countries, among others). And in this general transitional model, it becomes difficult to adapt the peculiar Colombian situation that requires other referential elements, insofar as the peace process and its laws and resulting institutions constitute, in themselves, a specific "model".

Likewise, the Colombian experience has led to a great deal of support through international cooperation in the form of continued support from the United Nations through the Post-Conflict Multi-Donor Fund, the Inter-American Court of Human Rights, and the activism of countless civil organizations. The diversity of victimising events, the exceptional number of people affected, and the complexity of the different groups involved in the conflict has meant that the archives lie at the centre of the State's obligations to satisfy the rights of victims. There is, therefore, a great variety of archives which can contribute to providing evidence in this process, notably the archives of public institutions, social organizations, communities, and individuals who have kept documents relating to different forms of victimisation.

Our analysis will focus - in summarised form - firstly on consolidated institutions which produce and/or hold documents necessary for fully exercising the principles of truth, justice, and reparation. Secondly, we shall centre on the most emblematic institutions arising from the development of the Integral System of Truth, Justice, Reparation and Non-Repetition (SIVJRNR) and whose action is based unavoidably on the use of a wide typology of documents. These are not "archival" institutions in the traditional sense of the word; however, their capacity to exercise justice and make reparations is directly proportional to their ability to obtain documented information, analyse it, protect it, and use it in the first instance as evidence in trials.

Amongst the institutions in operation before the signing of the country's Peace Agreement (2016), we should highlight the National Archives, the governing body on archival policy in Colombia. As we have seen when analysing the legal framework, this has produced agreements aimed at identifying and protecting archives relating to human rights (HR) and international humanitarian law (IHL) and has structured part of its policies jointly with the CNMH. At another level, there are numerous high-ranking state and legal bodies which also produce enormous volumes of documents which are essential to exercise citizens' rights and prevent impunity. ${ }^{12}$ These institutions have formulated modern systems of document management as effective support for their function.

The Human Rights Archives under the CNMH provides a significant amount of quantitative information on archives in the public and private 
sectors, which clearly indicates the wide range of organizations involved at all levels. The Executive Branch identifies 73 archive sources on subjects relating to serious human rights violations, a figure which increases to 1,566 if we include all its branches. At the departmental level, there are 823 bodies producing archive material and 19,441 at the municipal level. As regards court archives, there are 2,712 bodies with 68 different branches, and the authorities on ethnic groups, registered by the Ministry of the Interior, record 4,289 indigenous and 2,044 Afro-Colombian bodies. With regard to the private sector, the archives of non-profit making organizations, for-profit legal bodies, and material held by individuals and families must all be considered. This sector contributes significant figures: 2,709 victims' organizations, 388 human rights organizations, 22 universities, 87 media, and 10,205 health care institutions. In short, 16,512 sources have been identified globally, of which an estimated 3,000 are archives with relevant information (Centro Nacional de Memoria Histórica, 2017, pp. 135-137).

An organization of great interest which has resolved the issue of the fit between archival bodies and other related services is National Centre for the Historical Memory. Created under Law 1448/2011 (Article 146) as a public institution with legal status, its own assets, and administrative and financial autonomy, its principal objectives concentrate on recovering all documents and oral testimonies of human rights violations and reflected in the creation of the Human Rights Archives Directorate. In turn, it is also responsible for creating a Museum of Memory, running the Human Rights and Historical Memory programme, and designing and implementing action in favour of historical memory. In addition, Decree 4800/2011 laid down the components of the Human Rights and Historical Memory Programme, focused on promoting research for the reconstruction of the country's historical memory, organising education programmes, implementing a special register of historical memory archives in conjunction with the National Archives Agency, and preparing a protocol for archival policy on human rights and international humanitarian law.

To achieve these objectives and comply with the legal mandate, in 2018, the CNMH created an organisational structure made up of five directorates: the Construction of Historical Memory, the Museum of Memory, the Human Rights and Historical Memory Archive, the Truth Agreements, and the Administrative and Financial Directorate (Centro Nacional de Memoria Histórica, 2014, pp. 22-24). Its strength lies in the fact that, far from creating fragmented bodies, the CNMH integrates the archives within the framework of its human rights and historical memory policies. The most relevant milestones in the field of archiving are the publication of pioneering public policy on human rights archives and a protocol for document management; the formulation of a series of educational tools; ${ }^{13}$ the creation of a virtual archive; and the appointment of an International Advisory Committee (IAC) as a permanent collegiate body whose main mission is to 
provide strategic and technical advice on missionary issues and to position the Colombian experience in dealing with the past and building peace. ${ }^{14}$

As we have already pointed out in the section on the legal framework, there are numerous organizations which focus on reparation for those affected by a multiplicity of acts of victimisation and which require robust document and information management models to advance efficiently and safely in their work. This would be the case of the Land Restitution Unit which devised a Document Management Programme through resolution 00951/2016, in line with the principles of the AGN, that includes a policy document; an Institutional Archives Programme, PINAR; an Integrated Conservation System, SIC; and a wide range of archival instruments (classification table, inventory, document retention Tables, and an index of classified and reserved information). Also noteworthy is the Unit for the Attention and Comprehensive Reparation of Victims, which attends to the needs of more than eight million registered victims - a substantial proportion due to forced displacement. It has a single register of victims and, under resolution 2043/2012, created a documentation management group to support this enormous task of information and document gathering. ${ }^{15}$

To conclude the analysis of this first group of archives, operating before the Peace Agreement was signed, we must necessarily refer to the military forces, police, and intelligence and counter-intelligence bodies. Currently (2020), the intelligence community is made up of the Administration Department: the National Intelligence Directorate or DNI, which has replaced the defunct Administrative Department of Security, or DAS, the Information and Financial Analysis Unit, or UIAF, the Police Intelligence Directorate, and 16 dependencies of the Military Forces (Ramírez Mourraille et al., 2017, p. 11). Although the DAS was disbanded by President Juan Manuel Santos through Decree 4057/2011 after the scandals arising from verification of illegal phone-tapping of opposition leaders, as well as the collusion of some of its top leaders with paramilitary groups and drug traffickers, the archival fonds amassed during the 51 years of its operation (July 1960 to October 2011) are extremely relevant.

For the conviction of 21 high ranking officials and DAS personnel for illegal espionage from 2003 to 2008 against 300 citizens catalogued as a threat to national security (Ramírez Mourraille et al., 2017, pp. 34-35), ${ }^{16}$ the prosecutor's office seized exactly 103 "ring binder folders" containing 51,000 pages on this espionage from the archive of DAS's Sub-directorate of Analysis.

The seriousness of this scandal, the repeated exhortations of the UN High Commissioner for Human Rights from the year 2000, as to the need to review intelligence files for the purpose of correcting and deleting incorrect information and verifying the difficulty of democratic control over this type of files, led to the creation of an "Advisory Commission for Data Filtering and Intelligence Files" under the Intelligence and Counter-Intelligence Law of 2013. 
For their part, the institutions created under the Comprehensive System of Truth, Justice, Reparation and Non-Repetition (SIVJRNR, Sistema Integral de Verdad, Justicia, Reparación y No Repetición) arising from the Peace Agreement were also involved in the creation of the Special Jurisdiction for Peace, or JEP; the Commission for the Clarification of the Truth, or CEV; and the Special Unit for the Search of Missing Persons, or UBPD (Spanish acronyms). The CEV and the UBPD are extrajudicial bodies (they do not attribute responsibility or seek to prosecute crimes) and the documents and information they produce or collect cannot be used as evidence in legal proceedings.

The Special Jurisdiction for Peace, or JEP, was created by Act 1957/2019 on Administration of Justice and has a limited mandate (in principle, 15 years, remaining in force until 2033) and its main mission is to provide justice by clarifying and establishing individual criminal liability for the most serious and most representative crimes committed during the Colombian armed conflict and determining the legal position of all those who appear before the JEP.

Its task, therefore, is focused on investigating, judging, and sanctioning in order to respect the rights of victims to the truth, justice, reparation, and guarantees of non-repetition. Consequently, the collection, organization, use of, and access to, documents become a central element in its action. Due to its powers and objectives, the JEP is comparable to an International Criminal Court (such as those created for Rwanda or for the former Yugoslavia in The Hague, among others), and functions as a transitional body of justice.

In this sense, it takes the shape of a Peace Tribunal with its different sections, courtrooms, and with an extremely complex organization chart. The Investigation and Prosecution Unit (IUA, Unidad de Investigación y Acusación) plays a key role, along with an Information Analysis Group (GRAI), which answers directly to the JEP presidency. ${ }^{17}$ The organization has an unequivocal desire for transparency, which is reflected in its website publication of the text of proceedings and judgments within 24 hours of their promulgation, and it also performs a function of disseminating the jurisprudence from court rulings, which could be relevant to other court bodies. Finally, it maintains a consistent policy model and document management system based on best practice and national and international conventions and regulations.

Another institution resulting from the SIVJRNR is the Commission for the Clarification of Truth, Coexistence and Non-Repetition (CEV). Created by Decree 588/2017, it is an autonomous and independent body of national order and constitutional rank, with legal status and administrative, budgetary, and technical autonomy. This is an extrajudicial body, composed of 11 commissioners chosen for their professional competence, open to the participation of victims, and with a three-year mandate. Its main objective is to contribute to the recognition of the victims and the clarification of 
the events that have occurred, with the aim of promoting coexistence and becoming an organization that imparts the values of peace and reconciliation. Aware of the value of the heritage archives that will be produced and collected by the CEV, the decree of creation places special emphasis on the urgent need for adequately organising the information collected and guaranteeing the preservation of its document legacy for the future, after the closure of the CEV (Ibáñez Najar, 2017). Special mention is also made of prioritising public access to the information in its archive. ${ }^{18}$

The Search Unit for Missing Persons (UBPD) is a state body of a humanitarian and extrajudicial nature whose objective is to direct, coordinate, and contribute to the search, firstly, for persons reported missing as a result of the armed conflict and who are still alive, and secondly, in the case of death, wherever possible, the recovery, identification, and decent release of the bodies. The UBPD is responsible for disappearances that occurred before the 1st of December 2016 (date of entry into force of the Peace Agreements), in the following circumstances: forced disappearance, kidnapping, illegal recruitment, as well as those occurring during the hostilities between regular combatants (members of the armed forces) and irregular combatants (members of armed groups operating outside the law). It has a 20 -year mandate to search for missing persons in order to uphold the rights to the truth and to reparation. In the different phases of this search, mention should be made of an initial stage of collecting, organising, and analysing information. By 2019 , this body had collected information on nearly 1,000 cases, out of an estimated total of nearly 100,000 missing persons.

\section{The challenges}

The leading role of the archives in overcoming the armed conflict and in achieving a stable and lasting peace is a clearly verifiable fact, especially given the key role attributed to them by the most recent Colombian legislation and the assumption by the majority of state institutions involved in the resolution of the conflict of the need for an efficient system of document and archive management. Together with this positive aspect - of major importance - there are still some challenges to be resolved which can be summarised in two main areas: access to archives and the preservation of the documentary legacy of the conflict.

In spite of clear moves forward in a culture of transparency which has permeated the majority of Colombian institutions, there are still some sectors holding key information subjected to restrictions and opacity. Probably the most obvious case is the difficulty of access to the archives of the so-called intelligence community - a problem not only attributable to Colombia endorsed by a notable allergy to the scrutiny of their actions by democratic bodies. The importance of a judicious opening of these archives is justified by the sensitive nature of the information held, although a detailed analysis of relevant legislation provides some clarification in a sector where general 


\section{Ramon Alberch i Fugueras}

limitations are imposed and information "overclassified". This abusive limitation, alluding to general "reasons of state" as the basis for refusal, is compounded by serious difficulty in exercising democratic control over the document and information management of this type of service. In the Colombian context, and following the arguments of a group of renowned jurists from the organization, Dejusticia, the laws applicable to the Intelligence Community are the following:

- Law 1581/2012. Statutory Law on Personal Data

- Law 1621/2013. Intelligence and Counter-Intelligence Act

- Law 1721/2014. Law on Transparency and Access to Public Information

- Law 1755/2015. Statutory Law on the Right of Petition.

According to the authors cited, the challenge which arises from this multiplicity of laws is that "three of the four laws produce a legal contradiction in terms of access to archives and that, in practice, this contradiction has been resolved by the intelligence and counter-intelligence community in favour of a restrictive interpretation of access to archives" (Ramírez Mourraille et al., 2017, p. 47). Specifically, the law on intelligence and counter-intelligence considers that the nature of the functions carried out by these bodies (Article 33), their documents, and information are reserved, so that the maximum period of 30 years can be applied to them. Experts question whether this criterion can be applied in cases of human rights violations, and after a detailed and rigorous analysis of the laws (Ramírez Mourraille et al., 2017, pp. 77-90), they argue that it is unconstitutional to maintain a complete reservation across the board on intelligence and counter-intelligence documents, from which only the JEP is totally exempted and the CEV and the UBPD partially exempted.

Another element which needs a rapid response at institutional level is the preservation of this extraordinary legacy of documents currently being produced by the group of institutions that we have characterised throughout this article. And this preservation faces two challenges which must be tackled in parallel: in the first place, the protection of the archives in the face of any hypothetical action of abandonment or destruction. Secondly, the need to preserve documents which, to a great extent, are being produced electronically and whose sustainability requires costly investment. Experts in digital preservation and international projects on the subject (InterPares, Erpanet, Life) emphasise the major costs involved in maintaining authenticity and quality of electronic documents, for the purposes of evidence, in view of constant technological obsolescence, format conversion, and the periodical migrations that this material suffers. The economic sustainability of information stored on digital media is a key element, as is the creation of secure and reliable repositories for the long-term preservation of authentic, complete, reliable, and usable electronic documents. 
A reasonable possibility would be for the institutions that produce archives during the course of the peace process to join forces to create a shared repository, particularly the National Archives, which already has a National Digital Archive (DNA), the CNMH, the JEP, and the CEV. In parallel, and as a measure of protection for the future, to undertake sequential and cumulative action consisting first of declaring these heritage archives as an Asset of Cultural Interest, to then pass on to the relevant procedures for their entry in the Programme Register of the "Memory of the World". Both actions, beyond the "physical" fate of the Archive, would give it considerable security and protection.

Other aspects which deserve further discussion would relate to the state of organization of the archives - a substantial proportion lacking classification tables and with a limited use of description and inventory standards as well as the lack of adequate digitization protocols which produce massive digital copying processes without adequate information retrieval support (OCR uses, metadata models, etc.).

It should be reiterated that these are archives produced for the resolution of a conflict and, consequently, must adhere to the principles of truth, justice, and reparation in the short and medium term. Nevertheless, we must not forget that with the passage of time, their value will increase, as they become essential instruments in the processes of memory recovery, historical research, and public education in order to guarantee the non-repetition of such a conflict. ${ }^{19}$

\section{Notes}

1 Among the large number of publications on the "armed conflict", we would like to highlight the key research work and dissemination by the National Centre for the Historical Memory through the publication of nearly 200 studies between 2013 and 2018, under the direction of Gonzalo Sánchez.

2 The ELN was founded in 1962; the FARC in 1965; the EPL in 1967; and later M-19 appeared as a breakaway group from the FARC.

3 Of the 10,440 victims, $60 \%$ were military and the remainder civilians. These figures put Colombia in second place in the world in terms of the number of victims of landmines and explosive remnants of war, or ERW, i.e. abandoned or used munitions that had not exploded, such as grenades, mortars, and bullets.

4 According to the UN Secretary General (2004), transitional justice is "the full range of processes and mechanisms associated with a society's attempts to come to terms with a past of large-scale abuse in order to hold those responsible accountable for their actions, to serve justice and achieve reconciliation".

5 A tighter international context - especially monitoring by the International Criminal Court - prevented the granting of a broader amnesty, such as the one granted in 1990 in the case of the M-19 guerrilla group.

6 Some authors use the concept of infoxication to refer to the multiplicity of laws, decrees, and agreements, which have been drawn up in recent years from different viewpoints and in the interests of exercising those powers. This legislation constitutes a veritable legal labyrinth for public bodies and associations. 


\section{Ramon Alberch i Fugueras}

7 In particular, External Circular 003 (29 May 2012) on the "Archive census and document inventory of attention to victims of the armed conflict in Colombia"; External circular 004 (29 May 2012) on the "Responsibility of the National Archives and the National Archives System on the question of human rights; the Historical Memory Archives on the implementation of Law 1448 of 2011, the Law on Victims" and finally, Agreement 004 (21 April 2015) which regulates "the complete administration, control, conservation, possession, custody and assurance of public documents relating to human rights and international humanitarian law, which are held in the archives of state institutions".

8 This group was abolished by Resolution 102 of the 22nd of February 2019, by the management of the AGN, the National Archives. This has been functioning since November 2012. The resolution cites as reasons for its suppression of the fact that it had already met the objectives set for its creation, in addition to existing budgetary difficulties.

9 Decree 4803/2011, which lays down the structure of National Centre for the Historical Memory (Article 12); Decree 2244/2011 adding some functions to the CNM; and Decree 4158/2011, determining the assignment of the CNM. It should also be noted that Decree 1081/2015 stipulates that human rights archives contain documents which refer to human rights violations in a broad sense and breaches of international humanitarian law. They also emphasise that human rights archives should be the object of the measures of preservation, protection, and access defined within the international framework of human rights, jurisprudence, domestic legislation, and, in particular, the final paragraph of Article 21 of Law 1712 of 2014.

10 In particular, agreements 1746/2003, 2589/2004, and 8707/2011.

11 To consult the final agreement signed between the National Government and the FARC-EP guerrillas (310 pages), see a summary document on the six major agreements adopted, prepared by the Office of the High Commissioner for Peace (16 pages).

12 As a guide, we should mention the Constitutional Court, the Supreme Court of Justice, the Upper Council of the Judiciary, the Office of the Public Prosecutor, the Ombudsman, the Office of the Attorney General, and the Office of the Comptroller of the Republic.

13 Política pública de archivos de derechos humanos, memoria histórica y conflicto armado, Bogotá 2017, and jointly with the AGN, the Protocolo de gestión documental de los archivos referidos a las graves y manifiestas violaciones a los derechos humanos, e infracciones al derecho internacional humanitario, ocurridas con ocasión del conflicto armado interno, Bogotá, 2017. In terms of educational work, we should highlight the Caja de herramientas para gestores de archivos de derechos humanos, DIH y memoria histórica. Bogotá, CNMH, 2015.

14 The IAC operated regularly from January 2015 to August 2018 and was composed of five international experts on past events, covering archives relating to human rights; museums and places of remembrance; research for historical clarification; and the processes of reconstruction of the historical memory.

15 A final example would be the National Observatory of Memory and Armed Conflict which has a methodological guide (Bogotá, January 2016) explaining how to collect, store, and analyse information; collection instruments; the identification of sources of information; the management of these sources; and data collection. It also provides guidelines for handling: integration, classification and coding, review and validation, data repositories, analysis and interpretation, dissemination and archiving. The information and databases produced have been periodically transferred to the $\mathrm{DH}$ Archives Directorate of the CNMH. 
16 In 2009, the prestigious magazine Semana denounced the illegal surveillance of judges, members of international human rights bodies, and also of the UN Special Rapporteur on indigenous peoples. The documents seized by the Attorney General's Office for the court case reflected the wealth of information that can be accumulated by intelligence agencies; in this case, interception of telephones and Internet lines, illegal surveillance, threats, smear campaigns, theft of information, and other actions aimed at creating a climate of intimidation and insecurity.

17 We emphasise the importance of the JEP organization chart, insofar as it visualises the consideration given to bodies such as the Court Registry, the Executive Secretariat, a Special Peace Tribunal with 20 judges, chambers of justice with three chambers and four sections, and specialised services such as the UIA, the GRAI, and the Department of Document Management, which centres on the documents and information that provide key evidence and testimony.

18 The authors of this decree emphasise the desire to make this legacy a lasting one, as they are aware of other experiences where documents produced and collected by the Truth Commissions have been left piled up in attics or offices after they were no longer required.

19 Due to its link with the subject of archives, without this being a central theme in this chapter, we would like to mention the profound debate which has arisen between jurists, academics, historians, archivists, and human rights defenders regarding both the duty and right to remember, with reasoned arguments referring, for example, to individual/collective truth and procedural/historical truth.

\section{Bibliography}

Archivo General De La Nación, Centro Nacional De Memoria Histórica. 2017, Protocolo de gestión documental de los archivos referidos a las graves y manifiestas violaciones a los derechos humanos, e infracciones al derecho internacional humanitario, ocurridas con ocasión del conflicto armado interno. Bogotá: AGN \& CNMH.

Centro Nacional de Memoria Histórica. 2013, ¡Basta yaj. Colombia: memorias de guerra y dignidad. Informe general grupo de memoria histórica. Colombia: Imprenta Nacional.

-2014, Memoria histórica en el ámbito territorial: orientaciones para autoridades territoriales. Bogotá: CNMH, pp. 22-24.

—. 2017, Política pública de archivos de derechos humanos, memoria histórica $y$ conflicto armado. Bogotá: CNMH.

Centro Nacional de Memoria Histórica-Fundación Prolongar. 2017, La guerra escondida: Minas antipersonales y remanentes explosivos en Colombia. Bogotá: $\mathrm{CNMH}$.

Giraldo, Marta, and Toro, Luis, eds. 2018, Tramitar el pasado: Archivos de derechos humanos y museología viva. Medellín: Editorial Universidad Antioquia.

Ibáñez Najar, Jorge Enrique. 2017, Justicia Transicional y Comisiones de la Verdad, 2nd extended edition. Bogotá, Otzenhausen and Madrid: Biblioteca Derechos Humanos-Berg Institute.

Meto, Jorge Orlando. 2016, "Resumen del acuerdo de paz," Revista de Economía Institucional, vol. 18, no, 35, July-December.

Pécaut, Daniel. 2003, Violencia y política en Colombia: Elementos de reflexión. Medellín: Hombre Nuevo y Universidad del Valle. 


\section{Ramon Alberch i Fugueras}

Ramírez Mourraille, A. M., Ángel Arango, M. P., Albarracín CABALLERO, M., Uprimny YEPES, R., and Newman PONT, V. 2017, Acceso a los archivos de inteligencia y contrainteligencia en el marco del posacuerdo. Bogotá: DeJusticia.

Reyes, Alejandro. 2008, Guerreros y campesinos: El despojo de la tierra en Colombia. Bogotá: Grupo Editorial Norma.

Rodríguez, Jorge. 2017, Derecho a la Verdad y Derecho Internacional en relación con graves violaciones de los Derechos Humanos. Madrid: Biblioteca Derechos Humanos-Berg Institute.

Sánchez, Gonzalo, and Peñaranda, Ricardo, compilers. 2007, Pasado y presente de la violencia en Colombia. Bogotá: La carreta Editorial.

Tate, Winifred. 2007, Counting the Dead: The Culture and Politics of Human Rights Activism in Colombia. Berkeley: University of California Press.

\section{Web sources}

Archivo General de la Nación. Available at www.archivogeneral.gov.co.

Centro Nacional de Memoria Histórica. Available at www.centrodememoriahistor ica.gov.co y www.archivosdelosddhh.gov.co.

Comisión de Esclarecimiento de la Verdad. Available at https://comisiondelaverdad. co.

Dejusticia. Available at www.dejusticia.org.

Jurisdicción Especial para la Paz. Available at www.jep.gov.co.

Movimiento Nacional de Víctimas de Crímenes de Estado-MOVICE. Available at www.movimientodevictimas.org.

Rutas del Conflicto. Available at https://rutasdelconflicto.com.

Unidad Especial de Búsqueda de Personas Desaparecidas. Available at www.ubpd busquedadedesaparecidos.co.

Unidad de Restitución de Tierras. Available at www.restituciondetierras.gov.co.

Unidad para la Atención y Reparación de Víctimas. Available at www.unidadvicti mas.gov.co.

Verdad Abierta. Available at www.VerdadAbierta.com. 


\title{
14 Utilisation of the archives of the Peruvian Commission for Truth and Reconciliation (CVR)
}

\author{
Ruth Elena Borja Santa Cruz
}

\section{The times of the Internal Armed Conflict (CAI)}

At the beginning of May 1980, the political group entitled the Communist Party of Peru-Shining Path (PCP-SL: Partido Comunista del Perú-Sendero Luminoso) declared war on Peru. In their actions, they burned the ballot boxes in the town of Chuschi. However, this event took place almost unnoticed, because it occurred in a remote town in the department of Ayacucho. With this, the PCP-SL, led by Abimael Guzmán Reynoso, ${ }^{1}$ began the Internal Armed Conflict (CAI: conflicto armado interno) which, over the course of around 20 years, sought the destruction of the "old state". Then, in 1984, the Túpac Amaru Revolutionary Movement (MRTA: Movimiento Revolucionario Túpac Amaru), led by Víctor Polay Campos, ${ }^{2}$ began their violent action. These movements, the PCP-SL and the MRTA, were the two groups responsible for disrupting the governability of the country, through sabotage, kidnappings, murders, assaults, planting bombs, and other action aimed at the destruction of the "old state".

The violent action by these two movements caused significant anxiety and insecurity in the population. The response of the Peruvian State was swift, manifested in repressive actions through law enforcement and brutal repression, without making any distinction between the subversive elements in these movements and the civilian population at large.

In 2000, the government of Alberto Fujimori fell, as the result of a series of allegations of corruption presented on television channels (the Vladivideos). These complaints caused a wave of protests among the population, who took to the streets as a result of the corruption and repression which had manifested itself openly in that government. Mr. Fujimori travelled abroad to Japan, and in November of the same year, from the city of Tokyo, he resigned via a fax message. The resignation was not accepted by the Congress of the Republic and Fujimori was declared morally incapable of governing the country.

Faced with such a delicate situation for governance of the country, the President of the Congress, Dr Valentín Paniagua Corazao, was appointed as provisional President. His government then created the Truth Commission 
as a high-level body of the Presidency of the Council of Ministers (PCM), by Supreme Decree No. 065-2001-PCM. This Commission was ratified and later supplemented by Dr Alejandro Toledo Manrique, on the 4th of September of the same year. Finally, the Commission was entitled the Truth and Reconciliation Commission, by Supreme Decree 101-2001-PCM.

\section{The utilisation of public and private archives for the investigation work of the CVR and the creation of its Documentation Unit}

When the CVR was commissioned to investigate the acts of violence that occurred between 1980 and 2000, this required the use of information on this period, in particular information held in the libraries and archives of public and private institutions. Within the public institutions, the documentation of the Congress of the Republic, the Judiciary, the armed forces and the police were used for this purpose. In the case of private institutions, the documentation used was sourced from non-governmental organizations (NGOs), which had taken upon themselves the defence of the victims of the CAI or internal armed conflict (Borja, 2010) during the period between 1980 and 2000.

In turn, the research carried out by the press and television was also used, in addition to the work of the Catholic and Evangelical Churches in different parts of the country. Within its organisational structure, the CVR created the Documentation Unit (DU) ${ }^{3}$ to take on the challenge of collecting and providing bibliographical and archival information to the different areas of the CVR. To meet the needs of this service to the country, contacts were established and/or agreements reached with the different state organizations and individuals who could provide both the bibliographical material and archives available to them at that time. All the material collected was managed by the DU through its archive and library. Thanks to the bibliography and documentation collected and received by the DU from public and private bodies, it was possible to obtain the vital information in the following formats:

- Dossiers of denunciations of detentions, murders and disappearances presented by the different civil and religious organizations, filed before courts and international bodies

- Reports on cases of human rights violations drafted by the Commissions of the Congress of the Republic

- Court records on complaints of human rights violations in the different geographical areas of the CAI, housed in the archives of the Judiciary and the Ombudsman's Office

- Manuals and regulations on the actions of the military and police during the internal armed conflict, submitted by the Ministry of Interior and Defence 
- Publications on cases of massacres, arrests, disappearances, murders recorded by the press and television

- Audiovisual record of television news about the CAI

- Copies of books, magazines and theses on the CAI, held in both public and private universities.

Over the passage of time, the DU received the printed and audiovisual material produced in the different areas of the CVR, as part of its work. These materials were described and subsequently, when requested, served as sources of relevant information in the investigative work of the different areas of the CVR. Subsequently, the DU drew up a proposal for a classification chart of what was to become the central archive of the CVR. The organisational structure of the institution was taken into account for this purpose, and the different areas were worked with to organise, identify and describe its series of documents. The aim of this work was to guarantee orderly handling of the documentation, which subsequently facilitated the definitive classification chart, organising and describing the documentation on the different areas of the CVR.

\section{Series produced by the CVR}

1 Testimonies: Totalling 16,917 folders, held at the five regional headquarters, nationwide, with testimonies from victims, prisoners accused of terrorism, key political figures and members of the military and police forces. This material served for the different CVR divisions to be able to identify the victims, their dramas, and the lawsuits filed against the Peruvian State.

2 Public Hearings: The CVR has dealt with a total of 21 public hearings, held in the departments where the internal armed conflict, or CAI, had the greatest presence and impact. At the hearings, the testimonies of the victims and their families were heard, narrating their stories of horror and pain to the country, before an audience. This was broadcast publicly, so that the population could fully understand and discover what had occurred in remote areas during the period of violence that Peru lived through. At the same time, theme-based hearings were held where the patterns of human rights violations were presented to specific interest groups such as women, university students, individuals who had been unlawfully detained, covering the actions of the members of the Peruvian Self-Defence Committees and the problem of forced displacement.

3 Burial sites: The National Register of Burial Sites (RNSE: Registro Nacional de Sitios de Entierro), composed of 1,055 folders on burial sites, which are held at four different regional headquarters. This register identified 4,644 burial sites that formed the basis for the work of 
exhumation, identification and delivery of the remains of the victims to their families.

4 In-depth studies: These refer to the 19 subject areas that the CVR worked on to account for the events in each of the cases, areas and subject groups in their different geographical areas. This served to provide a broad overview of the violence; identifying perpetrators, patterns of violence, intensity of violence by region, behaviour of the key players in the CAI period and the actions carried out by them. This documentation was used to prepare the recommendations presented by the CVR to both society, at large, and the Peruvian state. The cases dealt with included Uchuraccay, the universities, the indigenous peoples, Asháninka, violence and drug trafficking, Raucana, Oreja de Perro and Villa El Salvador, among others. The CVR archive was used by institutions for the dissemination of the Final Report, the strengthening of the collective memory, justice and reparations.

\section{The utilisation of the CVR archive by institutions for the dissemination of the Final Report, the strengthening of the collective memory, justice and reparations}

Circulation of the CVR Final Report. On 29 August 2003 in the city of Ayacucho, the CVR presented its Final Report in nine volumes, and on the same date Supreme Decree No. 078-2003-PCM was published, creating the transfer committees to arrange for the delivery of the CVR heritage archive to the Ombudsman's Office, as well as submitting property, information and administrative, economic and financial documentation to the Presidency of the Council of Ministers. Consequently, the transfer to the Ombudsman's Office took place in November 2003 and was formalised in December of the same year, through the signing of the transfer certificates, with their respective transfer inventories.

Total heritage archive submitted by the CVR to the Ombudsman's office

$\begin{array}{ll}\text { Testimonials } & 16,917 \text { folders } \\ \text { Photos on paper } & 13,139 \text { photos } \\ \text { Negatives } & 3,810 \text { video strips } \\ \text { Videos } & 1,109 \text { videos } \\ \text { Master's degree (BETA, HI8) } & 428 \text { exhibits } \\ \text { Audios } & 18,696 \text { cassettes } \\ 78 \text { cases investigated } & 453 \text { folders } \\ \text { Burial sites } & 1,055 \text { folders } \\ \text { Libraries } & 1,150 \text { (books, magazines) }\end{array}$

Source: CVR to DP Transfer Agreement (2003).

After the Office of the Ombudsman had received the complete records from the CVR and the recommendation for its extensive dissemination 
throughout Peruvian society, on 19 April, 2004, ${ }^{4}$ the Information Centre for the Collective Memory and Human Rights (CIMCDH: Centro de Información para la Memoria Colectiva y los Derechos Humanos) was created. This centre was responsible for the dissemination of these CVR heritage records to court authorities, universities, schools, ministries, relatives of CAI victims, academics, and any citizen who may wish to know the truth about what occurred in Peru during the period 1980-2000.

For the process of installation of the records and their functioning, several foreign cooperating bodies collaborated: the $\mathrm{EU}$, the embassies and the UN Development Programme (UNDP). During the first years of work, emphasis was placed on making the Information Centre the body responsible for disseminating the content of the CVR document archive. The work began through talks in colleges and universities. At the same time, essay and photography competitions, photographic exhibitions, conversations and fairs were also held. The dissemination work was further strengthened by attendance at national and international events, which were decisive in publicising the work carried out by the CIMCDH through its website. ${ }^{5}$

Subsequently, the testimonies of the CVR, public hearings, photographic and audiovisual archives were digitised, thereby guaranteeing the preservation of the documents and facilitating a rapid dissemination service using computerised resources. The CIMCDH began work with one director and seven staff responsible for handling enquiries and ordering and disseminating the archives created by the CVR. The staff included three archivists who, in addition to providing attention, responding to inquiries and requests, were also entrusted with preparing printed documentation for digitisation. The digitisation of testimonies required a project, the duration of which extended to two years, resulting in setting up a human rights library specialising in the CAI period.

Since the creation of the CIMCDH, both judges and prosecutors have been the professionals who have most requested the services of consultation and reproduction of court files, testimonies and audiovisual material to process the cases presented by the CVR. Copies of the requested information were delivered in full to them. Other users have been NGOs specialising in human rights, requesting information on the cases of the corresponding jurisdictions that they were following up. Such were the cases of Cayara; Rigoberto Tenorio Roca, criminal cases; Los Cabitos and other representative cases, in the constant search for justice within the context of the transgression of human rights in Peru.

In the cases of military personnel and members of the police, professionals involved in judicial proceedings have been able to request a copy of the testimonies given by victims in cases where these professionals have been entrusted with investigations, and have been duly informed that they had the opportunity to appear in the court in question and request the corresponding documentation referring to their case. Members of Parliament of the Republic have also been added to the users, in cases where they have 
requested information on specific individuals linked to national politics, where these characters have been accused of being directly involved in acts of violation of human rights during the CAI period.

When both judges and prosecutors requested information in cases of rape, these were treated with the utmost discretion and care to ensure the personal privacy of the victims. It was recommended not to make this information public, thus guaranteeing the victims' right to privacy. The information provided was carefully utilised, because it was vitally important to guarantee access to the information but, at the same time, also guarantee the privacy and personal safety of those who gave their testimonies to the CVR. When testimonies have been requested by both national and foreign university students and academics, copies of these testimonies have been given, subject to prior review to ensure that the privacy and safety of the witness was not jeopardised.

In its archives, the CIMCDH holds files considered as reserved cases. These files contain information on protected witnesses, who have requested that their names should not be made public knowledge. These case reports could only be delivered to the courts in question, while emphasising the confidentiality of the information and the responsibility that the court authority must accept in order to guarantee confidentiality.

\section{The use of the CVR heritage for reparations to victims}

One of the recommendations of the CVR was the design and execution of a Comprehensive Reparations Plan (PIR; Plan Integral de Reparaciones), for the purpose of restituting rights and compensation for human rights violations committed during the period of violence. Therefore, during the Alejandro Toledo government, under Law 28592, the Comprehensive Reparations Plan (PIR) ${ }^{6}$ was drawn up, with the aim of establishing the legal framework of the Comprehensive Reparations Plan for the victims of the CAI period. The law provides that the High Level Multisectoral Committee (CMAN), set up under Supreme Decree No. 011-2004-PCM, should be the body responsible for monitoring the state's actions and policies in the areas of peace, collective reparation and national reconciliation.

In turn, the CMAN commission is responsible for the coordination and supervision of the PIR plan. The Commission, made up of representatives of various public institutions and civic organizations, as the coordinating and supervisory body of the PIR plan has as one of its main functions to organise the work of the different state institutions for collective and symbolic reparations, on behalf of the victims of the CAI period. To undertake its functions, the CMAN requests information from the CIMCDH on the CVR archive, on communities and individuals who were victims of the period, in order to draw up these symbolic and collective reparations.

This Law also created the Unique Register of Victims (RUV: Registro Único de Victimas), to be prepared by the Reparations Council (CR; Consejo 
de Reparación) that began functioning in October 2006 as a collegiate body which joined forces with the Ministry of Justice and Human Rights at the end of 2011, and which had previously been under the Presidency of the Council of Ministers.

For the development of the work of the Reparations Council, the Information Centre provided a copy of the CVR's database of testimonies; it also provided search and copy services for the files of the former Special Prosecutors for the Ombudsman and Human Rights Office of the Public Prosecutor and the National Human Rights Coordinator that assisted in identifying, verifying and registering the victims in the Unique Register of Victims.

\section{Strengthening the memory}

Since its creation, the CVR has set out to give a voice to the forgotten; to make visible the huge gulfs of information among the Peruvian population. It also pledged to draw attention to the terrible events that occurred over the last 20 years of the 20th century. It committed to building a memorial heritage in which everyone would be included, and to rescuing the memories of those forgotten and affected by the CAI, which is so vital to the construction of Peru's democracy. The CIMCDH, upon receiving the heritage archive of the CVR, committed itself to preserving and disseminating the memory of the years 1980-2000, through the different actions undertaken during the years of its operation.

Over the years, proposals for the preservation and dissemination of the memory of the IAC period have gradually been made. One of the main proposals came from civil society, working to set up museums and memorial sites; this initiative gained the financial support of international organizations and, in a few cases, also regional and local institutions (Reátegui, 2010).

Another of the institutions that works to preserve this heritage is the CMAN. This institution organises activities aimed at populations affected by the CAI period, promoting the installation of memorial sites: memorial houses and sanctuaries. Another project of the CMAN, ${ }^{7}$ linked to the commemoration, is the organization of comic strip competitions on human rights and national reconciliation, and discussions on the importance of memorial sites for the construction of a collective memorial of these events in our country.

The Reparations Council, as part of the policy of commemoration, proposed the Unique Register of Victims (RUV) in 2014, receiving the certificate of appearing in the Peruvian Registry of UNESCO's Memory of the World, for being a heritage archive that sheds light upon the history of the victims of the CAI, becoming an important documentary heritage of our Peruvian history that can be reviewed on the CR portal.

Another institution interested in the preservation and dissemination of the memory of CAI is the Memorial Site for Tolerance and Social Inclusion 


\section{Ruth Elena Borja Santa Cruz}

(LUM) (Del Pino and Agüero, 2014) created as a centre that organises cultural and educational, research-based and commemorative events. It also encourages dialogue on human rights issues, focusing on the period of violence in Peru, which covers the period 1980-2000. The LUM was inaugurated on 17 December 2015, after a process of implementation that began in 2008 .

The German government offered a donation of $€ 2 \mathrm{~m}$ to finance the construction and maintenance of a Memorial Museum, and this financing was accepted by the Peruvian government. Through Supreme Resolution No. 059-2009-PCM, the Peruvian government created a high-level committee (CAN: Comisión de Alto Nivel) that was responsible for guiding, organising, supervising and managing the implementation of the project. During the years 2009-2011, three different committee presidents were involved: Mario Vargas Llosa, the writer; Fernando de Szyszlo, the plastic artist; and Diego García-Sayán, the jurist.

During this period, the Museum was constructed on a plot of land on the Costa Verde and an international architectural tender was put out for the design of the centre, accompanied by a debate over the appropriateness of the term Museum and a change of the name to Memorial Site.

Subsequently, work began on the museum script and the first stone for the construction of the LUM was laid, fully discussing the implementation and operation of the permanent and temporary exhibitions of the LUM and its institutional introduction to Peruvian society. In addition, the relevance of a Documentation and Research Centre was discussed. This would provide users with the different digital archives, collected from the various public and private institutions, through its virtual platform. To date, the LUM is a benchmark in memorial issues, as it organises academic essay competitions, temporary exhibitions, shows documentaries and films, as well as organising book presentations, conferences and workshops related to the subject of the recent memory of our country and other parts of the world. It holds a digital heritage collection of documents, bibliography and documentaries that has been increasing with donations and acquisitions that are the basis for studies on the CAI period. ${ }^{8}$

\section{Progress and setbacks in the implementation of the CVR recommendations}

The creation and functioning of the CVR took place in a special context; as a country, we were emerging from a period of upheaval, authoritarianism and corruption. The CVR was set up during the transitional government, led by Dr Valentín Paniagua, who gave it all the guarantees for its work; the CVR was then ratified by the elected president, Alejandro Toledo, and began its work of clarification over the events during the period 1980-2000. Since its creation, the CVR has had a number of detractors that it has had to 
deal with; among the most furious were the representatives of the political parties that were in government during the CAI period. To this were added the armed forces and police, as well as representatives of the armed groups.

This context gives us an idea of just how difficult and delicate the work undertaken actually was. In turn, the work of the CVR was accused, by some politicians, of being in favour of terrorism because, among its members, there were commissioners who were active in left-wing political parties. Representatives of the groups in arms were accused of being from the right, and traitors to the interests of the people; and by the same token, members of the armed forces were accused of wishing to destroy the honour of the military forces with lies and allegations of being violators of the human rights of the population.

After submitting its Final Report, the CVR received many questions regarding the numbers of dead and missing. Consequently, a campaign was organised whereby the media questioned the salaries of the commissioners and called into question the veracity of the events described in the Final Report. These questions sought to obstruct the implementation of the recommendations given by the CVR.

During the government of Alejandro Toledo (2001-2006), work was carried out in compliance with the recommendations of the CVR. The CMAN, the PIR, the CIMCDH and the CR were created to set up an interdisciplinary project to take into account the period of the CAI and include information on that period in schoolbooks. In addition, turning now to health, the mental health of victims was made a priority, while in education, reparations in the form of educational scholarships were set up for the children of victims. In addition, the repair and improvement of the living conditions of the people who lost their homes and whose villages were razed to the ground during the CAI period was also stipulated.

During the government of Alan García (2006-2011), there was political interference in the progress on creating the memory of the CAI period; it was claimed that there was political bias in favour of terrorism in schoolbooks, due to there being a photo of the leader, Abimael Guzman, in a cage and wearing a striped prison suit. With this, the governing party (APRA) began to control the institutions where the recommendations of the CVR were being drawn up. It was during this period that President Alan García proposed that the donation of the German government for the construction of the Memorial Museum be reallocated to the construction of hospitals, roads and schools (Ledgard, Hibbett and De La Jara, 2018). This proposal was rejected by the human rights, intellectual rights and family rights organizations of the victims.

During the government of Ollanta Humala (2011-2016), some changes were made to promote the memory of the CAI period; work continued through the CMAN, the CR, the Ministry of Education and the Ministry of Justice, but very slowly and on a low budget. The LUM opened in 2015, 
with high expectations from family members and human rights organizations; but there was rejection from the armed forces and some political representatives who considered the LUM an apology for terrorism.

\section{The current challenges for the preservation and dissemination of the CVR heritage in order to strengthen the collective memory}

The CIMCDH houses the CVR's heritage archive and is responsible for the photographic exhibition (Yuyanapaq), ${ }^{9}$ which is exhibited on the sixth floor of the National Museum; the CIMCDH has budgetary difficulties in order to be able to preserve and publicise the CVR heritage archive. The CVR does not form part of the organisational structure of the Ombudsman's Office and therefore does not have a budget assigned to it to guarantee the number of staff needed to continue the work of digitising the CVR's heritage archive. As a result, we have a reduction in personnel. Currently, the CVR functions with three people, making it difficult to circulate the heritage memory of the CAI and further strengthen it.

In addition, the Yuyanapaq photographic exhibition also suffers from a lack of the budget that is so very necessary to maintain it in good condition. Since its inauguration, it has received visits from schoolchildren and university students, and from national and foreign visitors interested in finding out about the period of the CAI.

As a donation, the LUM (Memorial Site for Tolerance and Social Inclusion) has received the photographic archive of DESCO, an institution that formerly published the magazine Que hacer (What is to be done?). This archive contains relevant information on the period of the CAI. To date, the LUM's CDI (Documentation and Research Centre) has been digitising and describing DESCO photographs to then upload them to its virtual platform and make them available to users.

Finally, we can state that the LUM is the institution that houses the largest number of archives and publications of the CAI period and has posted this on its virtual platform, with free access, becoming an important reference point to strengthen collective memory in Peru. It therefore needs to be provided with a larger budget to ensure the feasibility of continuing the work of preserving and disseminating the events of the period 1980-2000.

\section{Notes}

1 Leader of the PCP-SL political group that declared war on the country in May 1980. To date, this leader is in prison serving a life sentence.

2 Leader of the MRTA political group that has declared war on the country since 1984. This leader is currently being held in a maximum-security prison, sentenced to life imprisonment.

3 The head of the Documentation Unit of the CVR was Rosario Narvaez. 
4 Set up under Law 28592 of the 28 July of 2005, regulated by Supreme Decree No. 015-2006-JUS and its amendments with Supreme Decrees No. 003-2008-PCM and No. 047-2011-PCM.

5 Available at www.defensoria.gob.pe/el-centro-de-informacion-para-la-memoriacolectiva-y-los-dd-hh.

6 Set up under Law 28592 of 28 July 2005, regulated by Supreme Decree No. 0152006-JUS and its amendments with Supreme Decrees No. 003-2008-PCM and No. 047-2011-PCM.

7 Available at https://cman.minjus.gob.pe/reporte-de-actividades/.

8 Available at http://lum.cultura.pe/cdi/.

9 Available at http://idehpucp.pucp.edu.pe/yuyanapaq/.

\section{Bibliography}

Borja, Ruth. 2010, "Los Archivos de Derechos Humanos en Perú,” COMMA, pp. 132-133.

Degregori, Carlos Iván. 2015, “Sobre la Comisión de la Verdad y Reconciliación (CVR) en el Perú,” in: Degregori, Carlos Iván, Portugal, Tamia, Salazar, Gabriel, and Aroni, Renzo (eds.), No hay mañana sin ayer: batallas por la memoria y consolidación democrática en el Perú. Lima: IEP, pp. 27-68.

Del Pino, Ponciano, and Agüero, José Carlos. 2014, Cada uno, un lugar de memoria: Fundamentos conceptuales del Lugar de la Memoria, la Tolerancia y la Inclusión Social. Lima: LUM, pp. 21-26.

Ledgard, Denise, Hibbett, Alexandra, and de la Jara, Blas. 2018, "Retos y estrategias para una política pública de memoria: el proyecto Lugar de la Memoria, la Tolerancia y la Inclusión Social (LUM)," Cuaderno de Investigación N²7. Lima: Escuela de Gobierno y Politicas Públicas de la Pontificia Universidad Católica del Perú, pp. 15-16.

Reátegui, Félix, coord. 2010. Los sitios de la memoria: procesos sociales de la commemoración en el Perú. Lima: IDEHPUCP. Available at http://idehpucp.pucp.edu. pe/images/publicaciones/los_sitios_de_la_memoria.pdf. 


\title{
15 Archives, truth and the democratic transition process in Brazil $^{1}$
}

\author{
Aluf Alba Vilar Elias
}

\section{The military regime: Brazil and Latin America}

The military dictatorship in Brazil was not an isolated case in Latin America. Other Southern Cone countries were subjected to similar abusive and violating regimes, which were borne out of the disputes emerging from a new global political and economic order at the time. In all of them, the Armed Forces played a lead role in constitutional breaches and the practice of violent and arbitrary acts: Paraguay (1954), Brazil (1964), Argentina (1966 and 1976), Uruguay (1973) and Chile (1973). The working class was controlled by enforcement in the unions, with arrests, assassinations of their leaderships and other direct actions. Political parties were dissolved and parliaments, in almost all cases, were closed or subjected to strict limitations, in addition to the disappearances, torture, murders and kidnappings of members of civil society. In the 1970s, there was integration between the five countries in coordinated acts of political repression against anti-regime citizens, which included the exchange of military intelligence for arrests, torture, surveillance, kidnapping and murders, etc.

When the military governments came to an end, a series of court cases was begun to assign responsibility and punishment to the perpetrators, principally the authorities in command at the time. Although Brazil officially recognised its responsibility through the Commission on Deaths and Disappearances in 1995, it took the unusual position of not carrying out a similar assessment of the serious violations of human rights that had taken place. It should be noted that the Southern Cone countries revised their amnesty laws, except Brazil, and established truth commissions. The social and international unrest caused by the lack of revision to the Amnesty Law in Brazil, of 1973 reveals the incompleteness of the redemocratisation process.

Not punishing perpetrators implies a suspension of the right to forgiveness and the truth, an imposed amnesia, weakening the work following the recommendations from the national truth commissions, increasing the risk of lost memory and forgetting. It concerns making use of the right to the truth as a resource for memory and justice. As Paul Ricoeur (2010) taught, to make a memory is to fight against forgetting, and forgiveness is what 
restores the power to act. The self-amnesty that took place in Brazil made it impossible to distinguish between Justice, with a capital letter to signify the institutional sense, and justice.

\section{Transitional justice}

Paul Van Zyl (2009) defines transitional justice "as an effort made towards sustainable peace after a period of conflict, mass violence or systematic violation of human rights". Its objective, according to the author, consists in "prosecuting the perpetrators, revealing the truth about past crimes, providing reparation to victims, reforming the institutions that perpetrated abuse and promoting reconciliation". He highlights how the scope of transitional justice has widened and developed in the last decade, in two relevant ways: the first relates to the conceptual elements of transitional justice that became legal obligations; the second corresponds to strengthening democracy.

The greater application of international law that has taken place in the last 20 years, due to the efforts of bodies such as the European Court of Human Rights, the Inter-American Court of Human Rights and the UN Human Rights Committee, has stimulated the establishment of clear standards with regard to State obligations in confronting human rights violations, as well as the prohibition of amnesties in these cases, given the imprescriptible nature of their crimes.

The first question that arises when discussing transitional justice in Brazil, whether as a policy with concrete actions or as a valid concept within a proposed universalism, is that of its very existence: is justice possible in the middle of the democratic transition process?

Quinhala (2013) questions the application of the concept of Transitional Justice in Brazil and in other Latin American countries. According to the author, the term, originating in the political sciences and international law, concerns the political and juridical measures undertaken during the period in which an authoritarian regime is substituted by a democratic regime. When introduced into an unstable environment, justice can never be fully delivered, because the political conditions are unable to implement it. The measures must balance different interests: those of the victims who demand justice, of the authoritarian governments and the new political leaderships concerned with ensuring democratic stability. Seeking to fulfil different tasks, the measures end up being considered unfair by all, as they are undertaken in the context of social tension. However, neglecting them can cause serious consequences such as the impunity of violence and damage to fundamental rights.

The succession of authoritarian, repressive and violent regimes suffered by Latin America caused deep social harm that remains underdressed. According to Genro (2010), the discourse had been fixed to portray the period as peaceful with economic advances, providing the basis for the current order and democracy. As a result of this, for the author, the governing 
bodies sought to establish a pact of silence, to avoid reviving the past in fear of bringing unhealed wounds to the surface. This kind of political use of memory in fact constitutes non-memory, as re-establishing it cannot be done without a conflict of values.

Amongst the approaches adopted in the Latin American context, memory politics are highlighted as an instrument used to redefine historical memory in order to further develop a democracy tarnished by abuses, excesses and violations. This is not only through memorials or public spaces designed for this purpose, but also through the use of archives as parts of this process, be it in their symbolic form (vestiges and monuments of the past), as a legal instrument (opening the archives relating to violations and their use as documentary evidence) or as extracts of discourse and forms of truth that communicate and fix narratives and ideologies that conflict with and/or nullify each other in a constant battle for memory.

Equally, it should be noted that a correct model of transitional justice does not exist, only one that is best suited to the specific social demands of those who were subjected to the abuses and had their rights violated.

\section{The National Truth Commission and the use of archives}

The concept of truth does not fit within the methods of adequacy, verification or falsifiability. Its scope is outlined, as Foucault stressed (2008), in discussions concerning its general politics, which are the discourses that it accepts and makes function as true. The specific effects of power will determine the set of rules by which we distinguish truth from falsehood. These effects are traversed by a need for truth which is connected to economic and political forces, being a constant object of social conflict and ideological struggles.

Within this argument, there is space to think about the procedures and techniques valued in obtaining the truth, which are undoubtedly influenced by scientific discourse and institutions. The model employed by the NTC certainly embraced this path, in which playing truth against falsehood would be capable of indicating what, by choice, is true. The weight of the State is felt in this intersection. Its institutions were put in place to discover and recognise the facts and their potential contradictions, by means of their apparatus, represented, among others, by Justice, and by the archives and their sources.

Ethical responsibility in reading historical narrative that, for Benjamin (2010), is not a continuous process, but rather a diversion with multiple branches, is defined by giving space to the history of the excluded, the defeated and the victims. It allows them to redefine their places in time, by permitting their voices and rewriting the uncertain past fairly, thereby combating the forgetting which is authorised by impunity. For this, archives are called to speak, and their words do not always correspond to their place of origin, as historical time, disputes or choices can offer them a new reading 
or a new argument. This has perhaps been one of the major challenges for the NTC: how to recover words from a place and time that no longer exist? We cannot forget the sensitivity of the facts in question and the complexity that is therefore involved: we are dealing with traumas, with searches for missing, dead and barbarously tortured loved ones, with recognition, retractions, accountability, etc. How does one collate memories from traumatic periods without injuring the dignity of individuals? How can one promote a fair narrative?

Every national working experience of truth commissions around the world has its own particular way of trying to find a path to justice to reconcile a traumatic past with a peaceful present, be it via the legal framework or through hearings that expose the versions silenced by violent repression. The way in which social groups chose that which satisfied their demands or the power relations involved in the process ranged from requests for forgiveness and recognition to criminal accountability. In the Brazilian case, the NTC was presented within a programme of government public policies focused on guaranteeing human rights, by establishing politics of memory with the objective of discovering, clarifying and recognising past abuses, giving a voice to the victims, without any punitive, persecution or judicial element.

The delay in implementing the NTC, which happened 27 years after the military regime, scant transparency and the lack of public dialogue about its implementation model, investigative methodology, workings and objectives, was a target for criticism from the social groups that had been fighting for decades for a revision to the Amnesty Law, for the establishment of responsibilities and for the truth of the whereabouts of the disappeared. This negotiated transition with no punitive element made it unviable to establish legal cases capable of judging and convicting the individuals who carried out persecutions and political crimes, causing more frustration.

Despite this, the NTC promoted extremely relevant political movements, discussions and déente for the country in terms of organised civil society. Many issues were revisited and debated, such as unrestricted access to the archives from the military regime period and the right to the truth and memory. Its implementation also provided an opportunity to locate the archives surrounding the military activities of the time, as it was equipped with powers to requisition documents, question people and carry out investigations.

Created by Law 12.528 , in 2011, sanctioned by the then President Dilma Rousseff, the NTC's objective was to: "Examine and clarify the serious violations of human rights committed ... in order to realise the right to memory and historical truth and encourage national reconciliation”, aiming, according to a message sent from the President of the Republic, Luiz Inácio Lula da Silva, to National Congress when the project was delivered (Brazil, NTC 2014, v.1), "to respond to a historical demand from Brazilian society to ensure the retrieval of memory and strengthening of democratic values". 


\section{Aluf Alba Vilar Elias}

With regard to its structure and internal workings, the NTC was organised in a collegiate model composed of seven council members nominated by the President of the Republic, at its inauguration on 16 May 2012.

The initial phase of its activity, between May and November 2012, consisted of administrative organisational activities, in planning the research work, contacting the relatives of victims and in defining the issues to be investigated. In July, the members formed three topical subcommittees: I subcommittee for research, generation and organization of information; II - subcommittee for "relations with civil society and institutions; III subcommittee for external communication. In December of the same year, development of the research work began, coordinated by the members of the Collegiate body with the support of advisers, consultants and researchers. Thirteen topical working groups were also established (BRAZIL, NTC 2014, v.1, p. 50-51).

From November 2013, the core expert body was formed to clarify the circumstances of the deaths and disappearances, as well as locations and methods of torture among other things. To this end, they carried out interviews, exhumations and searches, collated statements and produced documents which made up various reports. Public hearings were also encouraged, with the intention of listening to the victims, witnesses and agents of the repression. These hearings took place in more than 14 States, with the support of civil society and the state and municipal truth commissions, making a total of 80 events in which 565 testimonies were collected (BRAZIL, NTC 2014, v.1, p. 53-54).

Between February and August 2014, public hearings and sessions were organised to present the preliminary research reports. Eight presentations were arranged with live online streaming and press monitoring.

In total, from its inauguration on 16 May 2012 until 31 October 2014, the NTC gathered 1,116 testimonies, with 483 from public hearings and 633 in private (BRAZIL, NTC 2014, v.1, p. 55). The methodology used in the investigative and research procedures involved in the NTC's work appears unclear in its Final Report, which was met with criticism from the civil bodies engaged in monitoring it.

An analysis of the Final Report found no sections that deal exclusively with describing the methodology used in the investigations promoted by the NTC. Using the search term "methodology", sections were found within the topics "Assessments and inquirie" and "Gathering testimonies and statements from agents of the repression", in which the report highlights the use of official documents and oral testimonies to "reconstruct the facts" and the use of "material elements", but there is no more in-depth technical description or mention of the motive and scientific arguments that led to these methodological choices.

Another aspect found in the report was the importance given to the partnership created with the National Archives, specifically the logistical support offered by the institution, extensive access to its documents, IT 
infrastructure support for digitalisation, the availability and access to millions of documents, the access to and use of its database which holds information on other archival institutions in Brazil, facilitating data connections and online research and the gathering of the fonds created and accumulated by the NTC in the course of its activities for the institution.

\section{Archives and truth}

Although it is evident that the role of the National Archives in the functioning and completion of the NTC's work has been recognised, it is important to understand in what way the archival documents were used in this process and their role in affirming a truth. For this purpose, we refer to the interview carried out by Santana and Stampa (2014) with the NTC's ex-coordinator, Rosa Maria Cardoso, who stated that the use of archival documents had been greatly important for the research as well as to understand what happened in the past, but not as the exclusive source of truth or the facts.

Archival documents were key, together with oral testimonies, to the NTC's activities, but Rosa M. Cardoso lamented the difficulties caused by the lack of personnel specialised in handling documents who could adequately extract the information they were looking for. There was an urgent need to demonstrate facts, but supporting evidence to confirm them was lacking, creating gaps in the narratives that were difficult to fill.

By combining this perspective with the criticisms made about an unclear investigative methodology on the part of the NTC, it becomes clear that the demands of the restricted political interests in its creation and operation meant a fundamental part of the planning was passed over: an epistemological reflection on the uses and social functions of the archives and their documents.

No direct connection was found with the notion of truth guided by the uses of archives. On the contrary, it is noted that the use of oral testimonies had a greater role in the reconstruction of narratives, perhaps because of a methodological gap as previously discussed. Archival documents appear to be an auxiliary resource used in conjunction with oral testimonies. This is how their function was determined by the NTC's practices, by evoking the power/authority of the document, in the construction of socio-historical and political processes for institutionalising forms of truth, as a power which was activated discursively by the orality of the testimonies.

A contradiction was found, however, between the discursive uses of the archive versus the ideology of the document "to reconstruct the fact": although the NTC had reproduced, in some ways, the ideology of documentfact or archive-truth, its real investigative practices prioritised the use of oral testimonies, placing archival documents in an indicative position rather than fact, valuing the networks of meaning that circumvented those sources, whose discourses were compromised by belonging to the context of the military regime. 
Agamben, in the work entitled What Is Left of Auschwitz (2008), says that what remains is that which cannot be archived, the word. The testimony is pushed into the background by the language between that which can be said and that which is in fact said. As such, for him, the survivors' testimony of an extreme situation is the only possible account of an unprecedented and unimaginable barbarism. Only those survivors can establish their own terms, the truth of what they saw and lived, as the tragic experience they went through, singularly, made them unique witnesses to the unimaginable.

As such, the oral accounts of those who survived traumatic and unprecedented acts of violence become part of the archive which was not written, but formed by the word that is now on record, taking the material form of a document archivable by the NTC, protected by an institutional bias, e.g. National Archives, generating social effects (Frohmann, 2012): establishing the document-effect (Freitas, 2009) in processes of legitimisation, authority and truth regimes.

\section{Final considerations}

To contest the past is to be free to construct future, as well as present, possibilities; it is to work to diminish the normalisation of evil, of crime, of the heinous. The role of the archives in this objective is characterised by various nuances. On one hand, archival documents may act as possible vehicles of hidden or criminal truths, but, on the other hand, they may also contribute the right to exercise forgiveness, to truth and to memory by offering resources for society to free itself from traumatic memories, redefining historical narratives through certain discourses which were silenced in unfair disputes.

The constitution of archives is directly related to the agencies of truth, even as an instrument or apparatus of the state. Derrida (1995), furthermore, stresses that archiving produces as much as it registers an event, and as such it is our political experience of the so-called news media.

The search for truth promoted by the NTC's activities broke in some way with the notion of an intrinsic archival truth, even if discursively it was being driven by means of other elements such as justice or the right to the truth. The forms of truth are, in this way, more a resource for the construction of archives than the archives are for the construction of a truth, considering truth as a path on which the obscure points, the payments and the silencings are important.

\section{Note}

1 Aspects of this article are part of the research developed for the author's doctoral thesis which was supervised by Professors Georgete Medleg Rodrigues (University of Brasilia) and Lídia Silva de Freitas (Fluminense Federal University). 


\section{Bibliography}

Agamben, Giorgio. 2008, O que resta de Auschwitz: arquivo e o testemunho (Homo Sacer III). São Paulo: Boitempo Editorial, p. 175.

Benjamin, Walter. 2010, "Sobre o conceito da Historia," in: O anjo da história. Lisbon: Assírio \& Alvim.

Brazil. National Truth Commission. 2014, Report/National Truth Commission: Electronic Source. Brasilia: NTC.

Derrida, Jacques. 1995, Mal d'Archive: une impression freudienne. Éditions Galilée. English translation first published, “Archive Fever: A Freudian Impression," Diacritics, vol. 25 , no. 2 .

Elias, Aluf Alba V. 2017, Arquivo, verdade e o proceso de transição democrática no Brasil: o legado da Comissão Nacional da Verdade para a ampliaçãoo da discusão epistemológica arquivística. (Doctoral Thesis), Brasilia.

Foucault, Michel. 2008, Microfísica do poder. São Paulo: Graal.

Freitas, Lídia S. 2009, Documento e poder: uma arqueologia da escrita. Post-Doctoral Research Report. Post-Graduate Social Anthropology Program. National Museum, UFRJ.

Frohmann, Bernd. 2017, Documentasõ rediviva: prolegómenos a uma (outra) Filosofia da Informasão. Available at www.seer.unirio.br/index.php/morpheus/ article/view/4828, accessed August 2017.

Genro, Tarso. 2010, Dereito, Constitução e transição democrática no Brasil. Brasilia: Francis.

Quinhala, Renan Honorio. 2013, Justiçc de transição: contornos de conceito. Sao Paulo: Outras expressõe, Dobra Editorial, p. 252.

Ricoeur, Paul. 2007, A memória e história, o esquecimento. Campinas, SP: Unicamp. Santana, M. A., and Stampa, Inez. 2014, "Interview with Rosa Cardoso, Member of the National Truth Commission," Acervo, vol. 27, no. 1, pp. 11-16, January, June, Rio de Janeiro.

Van Zyl, Paul. 2019, "Promovendo a Justiça Transicional em Sociedades Pós-Conflito," Revista de Anistia Política e Justiça de Transição, vol. 1, January, June. Brasilia Ministry of Justice. 


\title{
16 Archives for truth and justice in Argentina
}

\author{
The search for the missing \\ persons
}

Mariana Nazar

\section{Introduction}

On 24 March 1976, in the context of a growing wave of repression, a civilmilitary dictatorship took power through a coup d'état in Argentina.

From that point on, the provincial governors were dismissed; the National Congress and the provincial legislatures were dissolved; the members of the Supreme Court of Justice were ousted; and trade unions and political parties were outlawed. Although disruptions of the democratic order, repression of conflicts between different social sectors; and appeals to violence had all been frequent throughout the 20th century, the dictatorship that commenced in 1976 was characterised by a degree of violence unheard of up till then, in particular, due to the introduction of state terrorism and the systematic application of a particular type of political crime: the forced disappearance of persons.

This form of illegal and systematic extermination was aimed at social and political militants who had been characterised as subversive elements. As Crenzel (2015) points out, the disappearances combined public and clandestine phases, because the detentions were usually carried out by members of the armed forces or security forces, either in uniform or civilian clothes, on public thoroughfares, or in private houses, and in the presence of witnesses. Detainees were then taken to clandestine detention centres, where they were tortured and, in the vast majority of cases, murdered and their bodies done away with secretly. From the investigations carried out so far, it is known that their bodies were either buried in anonymous graves, cremated or thrown into the sea.

Faced with these facts, a section of society denounced this, demanding to be told where the missing persons were and insisting that they reappear alive. During this period, already existing human rights organizations, such as the Argentine League for Human Rights (Liga Argentina por los Derechos del Hombre), created in the 1930s, were joined by others set up to denounce and resist the extreme political violence exercised by the State, with the aim of seeking the whereabouts of the missing persons, and taking legal action on the disappearances, such as the Peace and Justice Service 
Foundation (SERPAJ: Fundación Servicio Paz y Justicia, 1974); the Permanent Assembly for Human Rights (APDH: Asamblea Permanente por los Derechos Humanos, 1975); the Ecumenical Movement for Human Rights (MEDH: Movimiento Ecuménico por los Derechos Humanos, 1976); Relatives of the Missing Persons and Political Detainees (Familiares de Desaparecidos y Detenidos por Razones Politicas, 1976); Mothers of the Plaza de Mayo (Madres de la Plaza de Mayo, 1977); or the Centre for Legal and Social Studies (CELS: Centro de Estudios Legales y Sociales, 1979), among others.

These actions in favour of the national memory, truth and justice have been linked from the outset to legal claims concerning the existence of, and access to, documents that provide an account of the State's terrorist actions, insofar as these documents could serve as evidence to ascertain the fate of those who disappeared and establish liability, as well as being possible sources of the country's history and its memory. Just as the government denied and, at the same time, oversaw the existence of enforced disappearances, the perpetrators continued to deny the existence of documents that accounted for these processes.

The documents, as the basis for the actions of institutions - and in the absence of any official archival policies that would ensure transferrals and access - remained in the hands of these same forces. The possibility of any knowledge of, and access to, these was therefore subject to the public policies exercised by these same institutions.

For this reason, in this chapter, we shall present the responses which have been provided by the State, since the return to democracy in 1983, to the demand for access to documentation on the forced disappearance of persons, specifically presenting those provided during the Kirchner period (successive Kirchner governments, 2003-2015), because these demonstrated a firm will to devise reparations policies.

\section{The documents on the missing persons}

As stated earlier, from before the end of the dictatorship, relatives, survivors, organizations and individuals committed to political militancy, or the defence of human rights, have demanded access to the documentation produced during the dictatorship, which would provide an account of the repressive action taken by the State.

The Armed Forces and Security Forces have stated, historically, that all documentation from the period of the repression has been destroyed, referring to legislation passed during the last days of the Dictatorship (e.g. Decree 2726/83), which ordered the deregistering of all records on detention of arrested persons available to the National Executive, in an attempt to "pacify the country". In addition, a radio message was broadcast from the Commander-in-Chief of the Army, dated 23 November 1983, ordering the destruction of documentation related to what was termed "the fight against 
subversion". Nevertheless, some sporadic findings highlighted that it was necessary to continue the searches, as well as reconfiguring their format.

As one of the demands of society was to open up the archives, it became necessary to rethink which types of archives; in which records traces of the actions of state terrorism could be found; and how to establish crossreferences between them to supplement information.

Within the State, documents have been produced which refer to clandestine activities; some as a register of illegal activities and others as a means of bureaucratic back-up for the organization of these clandestine actions.

When members of the security forces declare that the documents were destroyed once their action had concluded, ${ }^{1}$ we understand that they are referring to the documents most closely linked to the illegal activities. For this reason, the conservation of some documents that provide an account of this action, in a direct way, was due to an act of conscious resistance, of intentional concealment, or the discovery of parts of documents during the actual trials.

A paradigmatic case of resistance is that of the photographs that Víctor Basterra, a detained activist who disappeared in the clandestine centre operating in the Navy's School of Mechanics (ESMA: Escuela de Mecánica de la Armada), managed to secretly remove. ${ }^{2}$ Another might be, because their origin is unknown, the intelligence documents containing statements taken at ESMA, published in 2009, under the name of the ESMA Documents, published by de la Campana (Documentos de la ESMA por Editorial de la Campana). But there were also cases of intentional concealment or use as an exchange pledge, such as the summary papers on the operations of the Army's 601st Battalion, provided by Orestes Estanislao Vaello, a former member of Army Intelligence, who gave testimony as a repentant witness before the National Commission for the Disappearance of Persons (CONADEP: Comisión Nacional por la Desaparición de Personas (File No. $3,675)$.

As pointed out in a CELS report:

Information disseminated by marginal publications and websites, nostalgic about state terrorism, to disqualify former militants in the $70 \mathrm{~s}$ (with data obtained in torture sessions and therefore from sources impossible to cite), added to the progressive reappearance of former repressors in government offices, bent on exchanging information for impunity, and the receipt at federal courts of official reports prepared during the dictatorship, all demonstrate that documentation which is, a priori, inaccessible to civil servants and magistrates, in fact circulates freely among the repressors and apologists of the dictatorship.

(Varsky et al., 2008, p. 62)

Some stray documents have also been found during court proceedings ${ }^{3}$ which, in some cases, have been circulated in journalistic investigations; ${ }^{4}$ or during projects to identify police documentation, as in the case of the 
horrifying logbook or bitácora which was kept by the repressor, Agustín Feced, in the Information Service of the Santa Fe Police, and which was found among the documentation of the Buenos Aires Police Intelligence HQ.

For this reason, a few years ago the strategy adopted was to investigate the documentation on the activities that had already been regulated by the State, in order to sustain this action. This is a complex task, insofar as it requires the coordination of various different institutions and organizations involved, to do this efficiently. It also requires a change of perspective in the search, because concepts, such as the archives of the dictatorship (implying a chronological cut-off point); the archives of the repression, which focus on the institutions which acted in this repression; or archives on human rights, focusing on the social organizations which acted through resistance, prove in the end to be inefficient.

This repressive action has left its mark not only on institutions with directly repressive functions, but also on other state institutions, and even on those of a society that was committed (by action, omission or opposition) to this.

\section{Public policies in response to the demand for a memory, truth and justice and archive documents}

Over the course of these almost 40 years, the appearance of archival documents has been closely linked to the political decisions and possibilities of each government.

When the last military dictatorship ended, and only five days after taking his seat in the democratic government, President Raúl Alfonsín decreed the prosecution of the Military Juntas and created the CONADEP. This body was to investigate human rights violations during the period of state terrorism and investigate the fate of those who had disappeared.

The final report of the investigation submitted in 1984 reported the existence of thousands of missing persons from 380 clandestine detention centres, and maintained that these events were the result of a systematic plan perpetrated by the government (which made this a key element in the trial of the military Juntas, ${ }^{5}$ held in 1985). This was published in book form under the name Nunca Más (Never Again) and the section referring to the problems of access to documentation states that "it has been possible to determine that there was a significant accumulation of documentation which has been destroyed, or which is kept hidden by the perpetrators of the repressive action". (CONADEP, 1997, p. 274).

After mentioning that the repressive operation mounted, due to its size and scope, must have required the use of supporting documentation, and that there is knowledge of orders for its destruction, as well as, presumably, concealment under the protection of military secrecy, it was concluded:

In fact, by destroying or concealing the documentation, the burden of proof has been reversed for the acts of the utmost gravity, committed during the de facto government, transferring over to this Commission, 
to the Judiciary and to the public in general, the difficult task of reconstructing events, with the scarce documentation available. However, on the basis of the statements obtained from those who were released, relatives of missing persons, members of the security forces and the few documents found, it has been possible to ascertain the essence of the illegal repressive action that was carried out.

(CONADEP, 1997, p. 275)

At the end of its work, CONADEP had produced an archive which, among other things, gathered together the largest number of reports and information on the disappearance of persons to date, totalling 8,960 cases. As Emilio Crenzel points out:

[A] significant number of them, 5580, were handed over to the Commission by Argentina's Permanent Assembly for Human Rights [APDH in its Spanish acronym], which had amassed them during the dictatorship and handed them over to the IACHR [Inter-American Commission on Human Rights] in 1979.

(Crenzel, 2015, p. 160)

In this way, the testimony of the survivors became the basic input for tracing the events that some intended to erase. ${ }^{6}$

In 1986, before the end of this presidential term, the court cases were blocked by the enactment of the Full Stop Law (Ley de Punto Final) and, in 1987, the Law of Due Obedience (Ley de Obediencia Debida).

In the following government, under Carlos Menem (1989-1999), along with the reintroduction of the neoliberal model, the work of the justice system was totally paralysed and a presidential decree pardoned the members of the military juntas who had been condemned, along with a number of high-ranking military officers who were still on trial. On the other hand, economic reparations measures were laid down for the victims of human rights violations committed between 1974 and 1983.

The year 2003 saw the start of the Kirchner governments when Néstor Kirchner took office as President of Argentina, with the Kirchners remaining in office until December 2015. One of the aspects that identified these governments was a new impulse - now maintained over time - in favour of reparatory public policies on state-led terrorism.

These policies were related to creating the necessary conditions for the punishment of the crimes, state recognition of the crimes, the search for truth, publicising what had occurred and economic reparation for the victims. This process of reparation had a very high social impact, insofar as it came hand in hand with policies for satisfaction, as regards the measures of both recognition and apology, and the policies on the country's memory. ${ }^{7}$ Likewise, new reparations laws ${ }^{8}$ were passed, and in the sphere of justice, measures began to make progress in the determination of criminal 
liability, generating the political and cultural conditions necessary to obtain new criminal trials. In 2003, the Due Obedience and Full Stop laws were repealed, and in 2005 the Supreme Court declared them unconstitutional. These exceptional advances made it imperative to locate documentation.

In relation to memory policies, this was a process linked to a general phenomenon, known as the explosion of the memory: a time marked by the proliferation of memorials, museums, commemorations and various cultural events to remember the past. In this direction, we are particularly interested in presenting the role of archives within these policies. Because these policies were focused centrally on memory and reparations, it was considered that the problem of archive documents would be resolved during the exercise of this policy. This perspective had, as its key landmark, the creation of the Archives of the Memory which, in some cases, did nothing more than directly attack precisely what they wanted to preserve.

\section{Among archives of the memory, research teams and general archives}

During 2003-2015, the documentation identified as being linked to human rights violations served various purposes.

In the first place, we should highlight that one of the first institutional moves to assess documents as sources of memory was produced by civil society, with the inauguration of the Open Memory (2000: Memoria Abierta) as an alliance of human rights organizations aimed at bolstering the memory of human rights violations, the resistance and the struggle for truth and justice.

At government level, specific institutions, the so-called Archives of the Memory (Archivos de la Memoria), were created. These were set up with a view to formulating policies oriented more towards a national memory, rather than preserving archives, and included functions that ranged from gathering, systematising and preserving documents from a particular period to contributing to prevention, investigation and prosecution of cases of human rights violations, promoting studies and research, setting up information networks, recovering property from clandestine centres, undertaking tasks of dissemination and education and even holding exhibitions or displays, courses, conferences, monuments, etc.

Somehow, in these institutions, the role of the archive was not defined as such, and a large proportion of archives created in Argentina do not hold any original documents, or even copies of them.

The first government-led memorial centre and archive created in Argentina was the Buenos Aires Provincial Memory Committee (CPM: Comisión Provincial por la Memoria) in the year 2000. Subsequently, and at national level, the National Memory Archive was set up in 2003. Today, with the exception of the provinces of Catamarca and Entre Ríos, each province has a Memory Centre which should fulfil the functions of an archive. In 
addition, there are Provincial Memory Committees in Córdoba, Santa Fe, La Pampa, Chaco, Mendoza, Misiones and Río Negro; Memory Archives in Salta, Chubut and La Rioja; Municipal Memory Archives in Corrientes; a Memory Space in the city of Buenos Aires and Formosa; a Memory Library in Jujuy; and there are currently plans to create a Memory Archive or museum in Neuquén.

Additionally, after the reopening of the trials for crimes against humanity, and in order to be able to provide supporting documentation, specific areas began to be set up for the collection of documentation that could be provided as evidence.

The first one was in the Ministry of Defence (to which the three Armed Forces report: Army, Navy and Air Force), within the Directorate of Human Rights and under International Humanitarian Law (2006), where an investigation team began operating in 2009, followed later, in 2011, by the Archive Modernisation Programme.

In 2011, the Special Group for Documentary Surveillance was created within the Human Rights Office in the Ministry of Security (to which the security forces report: Federal Police, National Gendarmerie and Prefecture). Also, in that year the Human Rights Office was set up in the National Securities Commission and the Commission for the Recovery of the Historical Memory was set up within the Ministry of Foreign Affairs. In 2014, a Human Rights sub-directorate was set up in Argentina's Central Bank.

Furthermore, we should also point out that the General Archive of the Nation, the General Archive of the Province of Santa Fe and the Historical Archive of the Province of Buenos Aires also received transferrals of document fonds on the violation and/or defence of human rights.

Each of these areas or institutions has designed the archives in a particular way, thus deciding on the processing of and purpose served by the documents. ${ }^{9}$ In this regard, we will briefly look at the cases which we consider have best weathered these tensions and overcome these difficulties, succeeding in reversing any possible manipulation of their document fonds. ${ }^{10}$

The first case to be mentioned is that of the Buenos Aires Provincial Memory Committee (CPM in its Spanish acronym). This was created in 2000 to preserve the documentation of the Police Intelligence Headquarters for the Province of Buenos Aires (DIPPBA) and make it publicly accessible. One of the first tasks it undertook was to digitise all the documentation, totalling 336 metres in length (predominant basic dates 1957-1998), after which, in 2003 , it was possible to open it up to the public for consultation, however only through reference library staff who made keyword searches using OCR (optical character recognition).

At that time, it was thought that digitization and OCR were the most efficient form of search, and that the mediating the investigations through the CPM staff - who ran the search and delivered copies of the documentation with the names crossed out - was the best way to preserve the sensitive data on those under investigation. As time went by, and the limitations of 
keyword searches became clear, there was also a need to understand the contexts in which documents had been produced, to make sense of the literal information they contained, as well as considering the deeply subjective significance of mediation in the research process. Thus, new lines of development were adopted, introducing archiving, as a discipline, into document processing.

The result was an intensive process to identify, classify and describe the fonds, its sections and series, published in 2010, ${ }^{11}$ with other methods of consultation becoming available in 2013 (Lanteri and Nazar, 2014). By 2015, 2,735 reports had been submitted to the Ministry of Justice; more than 11,500 personal enquiries had been answered; and more than 2,000 queries had been made by researchers.

In addition, the research work on the forms of registration of the information by the intelligence institution enabled concise explanation of the way the information had been produced and the links with other intelligence agencies (the so-called information community) for the purposes of political and ideological persecution and necessary for the system of repression to function.

As one newspaper article stated, "Information which enabled a subversive individual to be kidnapped produced further information, even if this was gathered through torture, and was remitted once again to the local authority, constituting a cyclical, constant and perverse methodology" (Andar, 13/08/2015). The Buenos Aires Provincial Memory Committee (CPM) even appeared as a plaintiff in the case investigating the actions of the DIPPBA, in the planning and execution of state terrorism. ${ }^{12}$

The next case is that of the Ministry of Defence. As noted, in 2009, a team by the name of the Survey and Analysis Team (Equipo de Relevamiento $y$ Análisis) was set up within the Human Rights and International Humanitarian Law Department to collect and analyse documentation of historical and/or legal value in order to collaborate in responding to requests for information from the Judiciary. This team began examining the archives of the Armed Forces, finding that they were not organised according to any clear criteria and that there were no measures in place for the preservation of the documents. For this reason, and with the technical assistance of the General Archive of the Nation (AGN: Archivo General de la Nación), the Modernisation Programme for the Defence Archive System (Programa de Modernización del Sistema de Archivos del Área de la Defensa) was created with the aim of designing, developing and implementing an archive management model to identify, classify, inventory and improve the conditions of preservation of the documents and undertake their digitization.

This work facilitated the task of the investigation teams, which have made extremely valuable contributions to Justice departments, especially by preparing reports on the functional structures of the repressive apparatus, presenting evidence on the chains of command, the circuits and functioning of information and the types of action taken. Most of the investigations 


\section{Mariana Nazar}

have been based on the analysis of the documentation carried out by different personnel qualification boards in the Armed Forces, to assess the performance of personnel. This documentation details the format of rewarding the fight against subversion and, in some cases, the specific mention of an episode.

Other documentation widely used are the Historical Annals of each unit, containing their annual report. For the case of the army "this document is fundamental since it enables identification, year by year, of the inspection personnel in the unit, besides adding relevant information" (Lavintman, López and Pankonin, 2017). Action taken by the military justice apparatus has also been widely accessed by the investigation teams; particularly when they commenced work to check whether episodes of illness, accident, desertion and/or salary embargoes of personnel were linked to acts of service. These include accounts of repressive action, references to the contexts in which this took place, and details of those involved.

Finally, the document fonds, the Supreme Council of the Armed Forces (CONSUFA: Consejo Supremo de las FF.AA.), which holds the documentation of Military Justice, was transferred and is open to public consultation at the AGN. This fonds also provides a great deal of information on clandestine repressive action. In the summaries, testimonies can be found from both civilians and members of the operations force that culminated in kidnappings and disappearances. Declarations giving an account of the final fate of the bodies of disappeared persons have even been identified. In addition, the Modernisation Programme managed to transform, and reverse, the sense of inaccessibility of the armed forces archives, ushering in the need for a public opening, as a way of collaborating with the basic requirements of the democratic state, and producing tools for their effective compliance, such as the archive guide and regulations on access. ${ }^{13}$ Both the reports of the investigation teams and the archive guides are available on the web in a tab on the Ministry of Defence webpage, entitled Open Archives (Archivos Abiertos)..$^{14}$

By mentioning these two cases, what we are trying to point out is the importance of the type of treatment given to archive documents in these cases. In other cases, which began with the perspective of memory or contribution to justice, certain types of documents or information were selected for their preservation or circulation, and access was denied (either actively or passively, by omission) to the rest of the documentation which would have shed light on this, thus supplementing the information. This information could have been read, taking a different viewpoint - or using other techniques developed years later. Although the use of certain documents was permitted, their preservation in the permanent and professional archive infrastructure typical of any State was not ensured in the long term. ${ }^{15}$ As noted previously, the archives were manipulated.

In a way, in this concealment of archiving tasks, the government became both victim and perpetrator, because it created the conditions to prevent 
good archive practice from being considered when designing both the rules and strategies adopted for documentation on human rights violations. Faced with designing memory-centred policies in a context of absence of official public archive policies, it was in the field of concrete practices that processing choices were made. And this depended, to a great extent, on the situation and technical and professional links of the key players in the process.

This same weakness, at some point, reinforced the perception that this had been a government policy, without this managing to take root and establish itself as a public, state-led policy.

The new presidency resulting from the 2015 elections implied a radical change, among other things, in public policies on human rights. The newly elected president, Mauricio Macri, had declared the previous year that if he became president, there would be no more "human rights jobs" (La Nación, 08/12/2014). After his electoral victory, several of the programmes suffered cuts in their budget, personnel and functions. By March 2016, the investigation teams and the Defence Archives System had cut their staff by a third, the Central Bank head office had dissolved the Human Rights Department, and the Ministry of Security dismissed the coordinators of the team working on the Gendarmerie and Federal Police archives, while the Human Rights Office Department was dissolved. As pointed out in a newspaper article of the time, in reference to the Ministry of Security, "Copies of the reconstruction of the internal regulations of the security forces and a census on the contents of the archives, which clarified structures and responsibilities in central aspects such as the death flights, literally ended up in rubbish bins" (Page 12, 28 December 2016).

\section{By way of conclusion}

Since the democratic opening of 1983, there have been several attempts to access information that would provide an account of the actions of the government during the Dictatorship, and in particular the fate of the missing persons.

Between 2003 and 2015, Argentina, as a state, produced a total change of paradigm by recognising the crimes that it had committed, facilitating the reopening of court cases and generating policies on its memory that included the preservation of, and access to, archives. We understand that these policies produced a movement of visibility and social condemnation of state-led terrorism, which would have been unthinkable 20 years earlier. At the same time, the reopening of the cases and the contribution to Justice has been considerable and effective, putting an end to a situation of impunity, contrary to national and international law, and recognising once again the dignity of those affected.

Nevertheless, in the area of archives, it has not been in the enactment of regulations that these policies have made a contribution. On the contrary, 
insofar as the state created these archive sites in a manner which was totally divorced from the regulations in force, and also divorced from the institutions traditionally responsible for carrying out these policies, it created these sites without providing the conditions for their work to be done efficiently.

\section{Notes}

1 By way of example, we have the conflicting statements that appeared in the press in January 1999, in reference to those made by Cristino Nicolaides to Judge Bagnasco and the public declaration by Martin Balza, the then Chief of the Army, claiming that there were no documents on the illegal repression. Clarín, 20/01/99 and 22/01/99.

2 Víctor Basterra was held captive for more than four years, from mid-1979 until the end of the military regime, although he continued under surveillance until August 1984, well into the democracy. He was kidnapped along with his wife and his newborn first daughter. With time, he was forced to forge documents (passports, identity cards and weapons permits) for officers and people with links to the Navy. This enabled him to make extra copies of photos and documents that were requested. When he began to obtain exit permits, he succeeded in taking out photos hidden in his underwear. In the trial of the Military Juntas, he gave the most convincing and longest testimony of the trial, providing all the photographic material and documentation that he had managed to obtain from the ESMA. For more information, see Brodsky, 2005; Larralde Armas, 2015.

3 Some examples are the lists of names and information on political militancy found during a visual inspection at the Automotores Orletti Clandestine Detention Centre in July 2006, which were found concealed in the walls, to cover up holes produced by bullets, and the documents found at the Customs office in Paso de los Libres, in the province of Corrientes. For more information, see Varsky et al., 2008.

4 One example is the article by BONASSO, Miguel: 'Lo que sabía el 601', on Página/12, 25/08/02, where a secret document from June 1980 is described, revealing some knowledge on Montoneros, in the hands of the Army. This can be found in Case 6859, in the charge of Judge Bonadío. Available at www.pagina12. com.ar/diario/elpais/1-9327-2002-08-25.html, accessed 28 February 2019.

5 The trial of the military Juntas (Juicio a las Juntas) is known as the trial of the members of the first three military Juntas during the dictatorship, undertaken by the civil justice system and initiated by a presidential decree, due to their grave and mass-scale human rights violations.

6 As Emilio Crenzel (2003, p. 79) points out, "the survivors who testify succeed in making it possible to transmit the topography of the horror to others; they are the master builders of their first map".

7 Compared to the purely economic reparations of the 1990 s, that can be identified as having an insurance policy format, as pointed out by de Greiff, "Reparations are not simply an exchange mechanism, similar to an insurance policy against criminal acts or a compensation system for victims when their rights have been violated. For something to count as reparation - as a measure of justice - it must be accompanied by the recognition of liability and linked, precisely, to truth, justice and guarantees of non-repetition" (United Nations, 2012).

8 Ley $\mathrm{N}^{\circ} 25.914$ Indemnización para Hijos; Ley $\mathrm{N}^{\circ} 26.564$ ampliación de los beneficios de las leyes $\mathrm{N}^{\circ} 24.043 \mathrm{y} \mathrm{N}^{\circ} 24.411$ y Ley $\mathrm{N}^{\circ} 24.043$ Indemnización para ex Detenidos. 
9 For a closer look at some of these institutions and the documentation they hold, see Guía de archivos útiles para la investigación judicial de delitos de lesa humanidad produced by Memoria Abierta. Available at www.fiscales.gob.ar/ lesa-humanidad/wp-content/uploads/sites/4/2013/08/archivos_investigacion_ judicial.pdf.

10 The concept of manipulation of archives is used to refer to situations where documents are managed on the basis of the need to complete one of the social functions of the archives: either to provide sources for history; or to serve for the institutional "memory"; or to contribute to justice. By focusing the tasks on serving one of these functions, the documents receive individual treatment in some, several or all archiving tasks (preservation, identification, classification, arrangement, assessment, description and access), often losing the completeness of their fonds and the context in which they were produced. See Nazar for the presentation of a case, 2018.

11 See Cesáreo and Novarini, 2013. Available at www.comisionporlamemoria.org/ static/prensa/archivo/cuadroclasificacion/\#seccion3.

12 This can be seen in an educational audiovisual available at www.youtube.com/ watch? $v=d C t S 2$ bdgjcY.

13 The result of this process can be seen at www.argentina.gob.ar/defensa/ archivos-abiertos/instituciones-de-archivo.

14 Available at www.argentina.gob.ar/defensa/archivos-abiertos.

15 See Nazar, 2008, 2012 for a more in-depth analysis.

\section{Bibliography}

Brodsky, Marcelo. 2005, Memoria en construcción: El debate sobre la ESMA. La Marca: Buenos Aires.

Cesáreo, Marina, and García Novarini, Cecilia. 2013, “Una estructura jerárquica conservadora se aggiorna: el Proyecto de Modernización de los Archivos del Área de la Defensa del Ministerio de Defensa," in: Actas XIV Jornadas Interescuelas/ Departamentos de Historia. Mendoza: Universidad Nacional de Cuyo. Available at www.aacademica.org/000-010/848.

Comisión Nacional Sobre Desaparición de Personas. 1997, Nunca más. Buenos Aires: Eudeba.

Crenzel, Emilio. 2003, El testimonio en una memoria ciudadana: el informe Nunca más. Buenos Aires: Revista de Estudios Avanzados.

—. 2015, "La reconstrucción de un universo: desaparición forzada de personas en la Argentina," in: Aguirre, Carlos, and Villa-Flores, Javier (coord.), From theAshes of History. Loss and Recovery of Archives and Libraries in Modern Latin America, Carolina del Norte. Editorial A Contracorriente. Available at https://uncpress.org/book/9780985371555/from-the-ashes-of-history/.

Lanteri, Magdalena, and Nazar, Mariana. 2014, "A 10 años de la apertura del Archivo de la DIPPBA. First Panel: Presentación de los instrumentos de descripción del fondo documental de la ex DIPPBA," Aletheia, vol. 5, no. 9, October. Available at www.aletheia.fahce.unlp.edu.ar/numeros/numero-9/conferencias/a10-anos-de-la-apertura-del-archivo-de-la-dippba.-primer-panel-presentacion-delos-instrumentos-de-descripcion-del-fondo-documental-de-la-ex-dippba, accessed 28 February 2019.

Larralde Armas, Florencia. 2015, "Las fotos sacadas de la ESMA por Victor Basterra en el Museo de Arte y Memoria de La Plata: el lugar de la imagen en los 
trabajos de la memoria de la última dictadura militar argentina," in: Cuadernos del Centro de Estudios de Diseño y Comunicación $N^{\circ} 54$. Buenos Aires. Available at https://fido.palermo.edu/servicios_dyc/publicacionesdc/vista/detalle_articulo. php?id_articulo=10591\&id_libro=511, última visita 28 February 2019.

Lavintman, J., López, H., and Pankonin, L. 2017, “Conocimiento histórico y justicia: el trabajo en el Archivo del Ejército Argentino,” Aletheia, vol. 7, no. 14. Available at www.memoria.fahce.unlp.edu.ar/art_revistas/pr.7890/pr.7890.pdf.

Nazar, Mariana. 2008, "Dictadura, archivos y accesibilidad documental: A modo de agenda," in: Derechos humanos en Argentina. Informe 2007, Informe Anual del CELS. EUDEBA. Available at https://www.liverpooluniversitypress.co.uk/ journals/article/31874/.

- 2012, "Archivos, memoria y derechos: reflexiones en torno al caso argentine," in: Comma 2010.2. Liverpool: Revista del Consejo Internacional de Archivos.

- 2018, "Secretos, reservados y confidenciales: la producción de información de las fuerzas armadas y de seguridad como fuente para la historiografía," en Estudios Sociales del Estado, vol. 4, no. 7.

United Nations. 2012, A/HRC/21/46 Informe del Relator Especial sobre la promoción de la verdad, la justicia, la reparación y las garantías de no repetición. Pablo de Greiff. Available at www.ohchr.org/Documents/HRBodies/HRCouncil/ RegularSession/Session21/AHRC-21-46_sp.pdf.

Varsky, Carolina, Barbuto, Valeria, Martínez, Diego, and Parellada, Julieta. 2008, "Justicia por los crímenes de la dictadura," in: Derechos humanos en Argentina. Informe 2007, Informe Anual del Cels. EUDEBA. Available at www.cels.org.ar.

\section{Articles}

Andar. 2015, "Causa DIPPBA, dossier: la inteligencia fue terrorismo de estado," 13 August. Available at www.andaragencia.org/causa-dippba-dossier-la-inteligenciafue-terrorismo-de-estado/, última visita 28 February 2019.

Page12. 2016, Instrucciones para terminar con una política de Estado, 28 December. Available at www.pagina12.com.ar/diario/elpais/1-295579-2016-03-28.html, accessed 28 February 2019.

La Nación. 2014, Mauricio Macri: 'Conmigo se acaban los curros en derechos humanos', 8 December. Available at www.lanacion.com.ar/politica/mauriciomacri-conmigo-se-acaban-los-curros-en-derechos-humanos-nid1750419. 


\title{
17 Chronicle of a backlash foretold
}

\author{
Guatemala's National Police \\ archives, lost and found and \\ lost - and found? - again ${ }^{1}$
}

\section{Kirsten Weld}

"Even ten years ago," the activist told me, "they would have killed all the people working on a project like that." It was 2008 , he was referring to the unlikely discovery and rescue of the archives of Guatemala's National Police three years earlier, and he was deadly serious. In 2005, a nighttime explosion on a Guatemala City military base had set in motion a shocking chain of events, culminating in the revelation that some 75 million pages worth of moldering police records, long and desperately sought by the families of the hundreds of thousands killed or disappeared by state security forces during the country's 36 years of armed conflict, had for years been hiding in plain sight in an urban storage depot. The political context at the time was inhospitable, to say the least. The war's root causes remained unaddressed, no army or police perpetrators had ever been prosecuted for their war crimes, and democracy activists were routinely threatened and harassed - or worse. Nevertheless, in the following years, a quixotic citizen effort to preserve and provide public access to this enormous corpus of files not only survived, but also thrived, making headlines around the world for its unlikely success in digitizing the archives and making them available for courtroom justice and historical research (Weld, 2014). Perhaps, as the activist suggested cautiously, things in Guatemala really had changed.

Or had they? A decade after our conversation, a full-spectrum assault on the country's tentative turn toward postwar reckoning had taken shape, and what had since come to be known as the Historical Archives of the National Police (AHPN) would sit squarely in the cross-hairs. Guatemalan conservatives, newly empowered by the presidencies of Jimmy Morales at home and Donald Trump further north, showed that they, like their counterparts elsewhere in Latin America, had made a strategic recalculation. To destroy dissenting political visions, they realized, no longer required assassinating all the dissenters. Instead, the law could be conscripted, and bent where necessary, to do the work, as seen in the so-called judicial coups undertaken in Honduras (2009), Paraguay (2012), and Brazil (2016). Dismantling the country's vaunted UN-backed Commission Against Impunity (CICIG), 
reversing hard-won anticorruption reforms in the judiciary, and effectively shuttering the National Police archives - all this could be done without firing a single bullet. It was thusly that the AHPN went from an improbable triumph to a tragedy foretold, a defeat cruelly snatched from the jaws of a victory that no one had quite been able to believe in the first place.

Guatemala's archive story has been unusually dramatic, but its core elements, above all the intensely political nature of access to state archives, are familiar to pro-democracy activists and archives managers the world over. Archive power is, after all, an essential element of state power. The gathering, storage, and use of information about subject populations is fundamental to the work of governance, whether for good (urban planning, provision of services, distribution of resources) or for ill (surveillance, gerrymandering, political repression). Much can be gleaned about the nature of a particular regime by examining its archival practices; a shift from military to civilian rule, for example, should necessarily include a shift in policies regulating public access to information. But the extent of that shift will always depend on the intersection of multiple factors: the depth of the regime's commitment to democracy and transparency; the existence of independent archival institutions with the capacity to resist politically motivated interference; robust legal frameworks to guard against such interference; the availability of funding, infrastructure, and trained archival personnel; the vigilance of international allies and observers; and, crucially, the degree of citizen mobilization around access. Fragility in one area imperils the whole endeavor.

The saga of the AHPN is not the first time that Guatemala's historical processes have unfolded at an outsized scale, its asymmetries of power uncommonly stark. And as in previous moments - such as its especially gory iteration of the Spanish invasion in the 16th century, the Central Intelligence Agency-assisted overthrow of democratically elected president Jacobo Arbenz, or the genocidal violence its security forces wrought upon civilians during the 1980s in the name of fighting communism - the specifics of the Guatemalan experience illuminate the broader phenomena at hand. Compared to the AHPN, other bodies of threatened records will tend to be less monumental, their physical condition less degraded, the backlash against their rescue less severe. But it is in the very extremity of its conditions, with the fact of its muzzling being only one twist in a tale that has consistently defied all expectations, that the AHPN makes manifest the dizzying stakes, and the electric archival politics, of historical knowledge production.

Shedding light on the tremendous violence of Guatemala's long internal armed conflict has proven a steeply uphill struggle. With the exception of Colombia, it was the region's most devastating Cold War era confrontation: as many as 200,000 Guatemalans were killed, 45,000 more 
were made to disappear without a trace, and the military state perpetrated acts of genocide against the indigenous Maya population as a core component of its counterinsurgency strategy. In 1996, the army and what remained of the Unidad Revolucionaria Nacional Guatemalteca (URNG) guerrilla forces signed peace accords. Among a set of measures designed to promote "reconciliation," if not accountability, the accords established a UN-sponsored truth commission called the Comisión para el Esclarecimiento Histórico (CEH), which was in theory entitled to access to any and all state documents it deemed necessary to carry out its investigation of human rights violations committed during the war. Because it was obvious that Guatemalan state forces had committed the vast majority of those violations, which included hundreds of scorched-earth massacres in civilian communities as well as the targeted assassinations of thousands who opposed military rule, government documents would have been a critical source of evidence. But, as CEH lead commissioner Christian Tomuschat later attested, the sitting government, closely allied with the military, stonewalled the commission, claiming that the relevant files had been stolen, lost, or destroyed (Tomuschat, 2001). The CEH was forced to base its study primarily on forensic evidence and oral testimony - allowing the military to dismiss the final report because it was not, as generals disingenuously proclaimed, substantiated by documentary evidence. That the report attributed $93 \%$ of the war's human rights violations to the state and state-led paramilitary groups might have had something to do with the strenuousness of their denials (CEH, 1999). When the commission issued its final 1999 report, a searing 12-volume excavation of a 500 -year-long history of racism and dispossession, the president refused to accept it at the ceremony, and the military high command stood up and turned their backs to the stage. It was a muted response compared to how the army had reacted to the Catholic Church's parallel truth-seeking effort, the Proyecto Interdiocesano Recuperación de la Memoria Histórica (REMHI) led by Bishop Juan José Gerardi Conedera, a year earlier. Two days after REMHI released its four-volume report, military intelligence operatives ambushed Gerardi outside his parish house and bludgeoned the beloved pastor to death with a ragged chunk of concrete (REMHI, 1998; Goldman, 2008).

It would be an understatement, therefore, to say that the horizon of possibility for historical reckoning and justice in the wake of the Peace Accords was narrow indeed. Those pushing to exhume mass graves, secure reparations for affected communities, or prosecute the architects of state violence were routinely targeted for retaliation. Gerardi's assassination was designed to send a message: forget the past, or else there will be consequences. The threat failed to derail the work of the country's most committed justice activists, but the realities of the stagnant postwar power structure largely thwarted their efforts, preserving impunity for army and police perpetrators and constituting a democracy in name only. 


\section{Kirsten Weld}

This made it all the more surprising when, in the summer of 2005, investigators from the human rights ombudsman's office (PDH) accidentally stumbled upon the archives of the now-defunct National Police while conducting an unrelated investigation in a little-traveled corner of a sprawling Guatemala City police base. Though it was the army that had executed the rural counterinsurgency and thus had killed the largest number of people, it was the National Police who had carried out much of the surgical violence in the capital city, often on the orders of military intelligence: the targeted killings and disappearances of student activists, labor leaders, progressive clergy, and university professors. As a result, finding the police's files - which the $\mathrm{CEH}$ had been blocked from consulting - had the potential to upend the postwar status quo, promising not only information that would help bring closure to bereaved families, but evidence of war crimes, written in the state's own hand.

The warehouse where the police files were found was an unbelievable scene, the dimensions of which were impossible to photograph and even harder to describe: tens of millions of documents rotting away in a halffinished warehouse, infested with rats and bats, resplendent with mold in many colors, dying a slow death of decay and neglect. It proved to be the largest discovery of secret state documents in the history of Latin America, roughly 75 million pages worth, and there was no precedent for how to deal with these papers, especially given the controversial nature of their contents. But in many respects, human rights advocates had been waiting for just such an opportunity, and they were ready to take the risk of trying to transform this archive of terror into an archive of justice. The rescue initiative that began immediately to take shape was at once intensely local - originally composed of staffers lent to the PDH by other human rights organizations and later supplemented by university students and others from the city's social justice community - and profoundly international, shaped by assistance from a coalition of allies based throughout the Americas and Europe. On the ground, the rescue team delved into the grimy work of digging through the heaps of paper and taking stock of what had been found; lacking any comparable precedent for how to deal with a discovery of this magnitude, these amateur archivists set about, somewhat improvisationally at first, figuring out how to clean, organize, interpret, and digitize the documents. Experts from abroad in human rights archiving would provide crucial assistance with strategic planning, as well as training in archival practice; the $\mathrm{PDH}$, taking advantage of its relationships with the international development agencies of governments like Switzerland and Spain, set about raising funds to support the work, with those funding streams outlasting the PDH's formal involvement with the archives. Though no one involved knew for how long they would be allowed to pursue it, the initiative's goal was clear from the outset: to restore the files and, in a sense, to repatriate them, to give them back to the Guatemalan people by organizing them, interpreting them, and making them available to the public. 
Despite much opposition faced along the way, from political interference to arson attempts, the AHPN, as it came to be known, came to stand as a landmark example of what could be accomplished in terms of citizen empowerment vis-à-vis archives - not just in Latin America, but worldwide. At its height, it counted on an annual operating budget of more than 2 million dollars and a staff of roughly 150 people. Gustavo Meoño, formerly part of the national directorate of the Ejercito Guerrillero de los Pobres (EGP), led the AHPN from 2005 on with a capacious and creative spirit. Interested parties from outside the project - documentary filmmakers, photographers, novelists, academic researchers, groups of local students, and more - would find themselves welcomed, security conditions permitting, and invited to produce their own interpretations of the rescue project unfolding before them (Doyle, 2007; Stelzner, 2009; Rey Rosa, 2009; Guberek and Hedstrom, 2017). By 2009, a public consultation service was open and running, allowing everyday citizens and human rights lawyers alike to conduct research. The AHPN pioneered collaborations with likeminded initiatives, such as the Forensic Anthropology Foundation of Guatemala (FAFG), which exhumes mass graves and uses DNA analysis to try and identify the remains, hoping to repatriate them to surviving family members; the FAFG and AHPN worked together to try and match some of the many unidentified corpses buried in Guatemala City's main cemetery with police records that might offer some clues as to these bodies' identities (Jones, 2016). The AHPN also took pains to share its resources, in particular its trained staff and high-volume scanners, to help digitize other collections of records at risk - important in a country which at the moment of the police files' discovery had fewer than ten trained archivists, and where the AHPN's access to foreign funding meant that it had access to far greater financial and technical resources than even the Archivo General de Centro América (AGCA), the country's national archives. It provided critical evidence in an array of human rights prosecutions, helping break the logjam of impunity that had hitherto protected the perpetrators of war crimes. And, most famously, the AHPN managed to digitize some 20 million pages of the files, backing them up on remote servers in the United States and Switzerland and making them freely available online by way of a collaboration with the University of Texas at Austin, with the hope that digitization would help guarantee continued access to the archives' information in the event of any future threat to the physical papers.

In short, then, the AHPN managed to considerably widen Guatemala's postwar horizon of possibility - although, of course, it did not do so alone. Rather, a constellation of actors and initiatives collectively co-produced the conjuncture that enabled the AHPN to flourish. The UN-backed Comisión Internacional Contra la Impunidad en Guatemala, or CICIG, set up shop in 2007, and for more than a decade it worked to root out corruption and the influence of so-called parallel powers in the country's government and judiciary, notably leading to the 2015 ouster and arrests of President Otto 


\section{Kirsten Weld}

Pérez Molina and Vice-President Roxana Baldetti for customs fraud (Open Society Justice Initiative, 2016). In 2010, the crusading reformer Claudia Paz y Paz took the helm of the Public Ministry as Attorney General, and in her four-year tenure she oversaw a brisk cascade of successful prosecutions of army and police officials for high-impact human rights crimes committed in the late 1970s and 1980s - including a historic trial of former dictator Efraín Ríos Montt for the crime of genocide. ${ }^{2}$ Two key offices more often than not occupied by antagonists of postwar justice, the Guatemalan presidency and the United States ambassadorship, were during this period held by sympathetic figures, Álvaro Colóm and Stephen McFarland. That the stars seemed to align during these brief years was no cosmic accident, but the fruit of many years of difficult and dangerous work by activists who had devoted their lives to the idea of a more humane Guatemala, and who had managed, briefly, to seize this propitious moment.

The AHPN and its sister initiatives faced hostility from their earliest days, but as the prosecutions of perpetrators gathered steam, the reaction intensified. As the Ríos Montt trial unfolded, Guatemala's Congress overwhelmingly passed a declaration stating that there had been no genocide, with its president stating, "what we as a Congress are saying is let's forget the past." A far-right organization called the Foundation Against Terrorism published blacklists of the justice activists involved in ongoing legal cases, and its supporters appropriated their adversaries' visual repertoires, parading through the streets bearing photos of family members they claimed had been killed by Communists. Organizations like AVEMILGUA, the powerful military veterans' association, took out paid advertisements in local newspapers threatening violence. For a time, despite these worrying signs and the project's ongoing legal and political precariousness, the AHPN continued its regular work, digitizing records, facilitating access for researchers, and assisting in legal cases.

But one prosecution, of five high-ranking army officials found responsible for the 1981 abduction, torture, and rape of Emma Guadalupe Molina Thiessen and the forced disappearance of her 14-year-old brother Marco Antonio, would prove, in Meoño's words, "la gota que rebasó el vaso" the final straw (Colombia 2020, 2018). And when it did, the favorable context that had insulated the AHPN from attacks during its first decade had dissipated.

In 2016, a political neophyte and comedian named Jimmy Morales, then best known for his blackface routines, was elected president of Guatemala, running on a conservative platform. Coalescing quickly around him were the power players and interests of a previous era: AVEMILGUA, the business elites, the oligarchy - the very sectors which had been targeted by the recent turn toward increased transparency, anticorruption campaigns, 
and postwar justice. Morales's victory emboldened long-standing enemies of CICIG, the AHPN, the Public Ministry under Thelma Aldana (Paz y Paz's successor), and the entire constellation of human rights and justice organizations at work in Guatemala. Those enemies would mobilize swiftly to enact what they referred to openly as a counterrevolution (Doyle and Oglesby, 2018).

Just as international circumstances had assisted the work of the AHPN in calmer times, so too would international circumstances fuel the fires of this counterrevolutionary effort, because, as it happened, Morales was not the only political neophyte elected to a presidency in the Americas that year. Donald Trump took office with narrow and self-serving priorities when it came to Latin America policy. First, he wanted allies in his push to move the foreign embassies in Israel from Tel Aviv to Jerusalem, a pet cause of U.S. evangelicals. Second, he wanted to roll back the steadily increasing uptick of children and families fleeing poverty, violence, and climate change in Central America, whom he called "invaders" (Peters, 2018). That Morales's aspirations were equally narrow and self-serving would form the basis for a realignment of the Guatemalan political landscape. Morales, under investigation by CICIG for having accepted illegal campaign contributions in the 2016 election, hoped to seek exile in the United States after his term in office ended, to avoid facing criminal charges for illicit self-dealing. Eager to please the Trump administration, he promptly moved Guatemala's embassy to Jerusalem and presided over the creation of a "safe third party agreement" which enabled the United States to deport asylum-seekers to Guatemala (Noack, 2018; Narea, 2019).

As this craven deal unfolded, arguments began to be heard in the Molina Thiessen case, which had been wending its way through the courts since 1997. The accused were all "untouchables" from Guatemala's military high command: Manuel Antonio Callejas Callejas, Francisco Luis Gordillo Martínez, Edilberto Letona Linares, Hugo Ramiro Zaldaña Rojas, and, importantly, Manuel Benedicto Lucas García, the ex-chief of the General Staff of the military. Letona Linares was acquitted, but the other four were convicted in May 2018 and collectively sentenced to more than 200 years in prison (Burt and Estrada, 2018). This was dangerous territory indeed. Benedicto Lucas García had friends in very high places: he and his wife had been major players in Morales's electoral campaign, and he was the brother of former dictator Romeo Lucas García (Gutiérrez Valdizán, 2016). And the AHPN had provided indispensable documentary evidence to the prosecution (Antonio, 2018).

After the conclusion of the Molina Thiessen case came the deluge. In August 2018, Meoño was summarily removed from his position as AHPN director, initiating a procedural coup against the Archive (Doyle, 2018). Meoño faced death threats and had to leave Guatemala; as of this writing, he remains in exile. The remaining employees were placed on temporary contracts, soon to be fired outright. Control of the AHPN was transferred 


\section{Kirsten Weld}

from the national archives to the Ministry of Culture and Sports, which was run by a Morales loyalist. In January 2019, the Morales government announced that it would terminate the mandate of CICIG; in March of that year, it issued an arrest warrant against Thelma Aldana, who had been planning to run for president but instead fled into exile; in May, interior minister Enrique Degenhart announced severe restrictions on public access to AHPN documents, and threatened legal action against the "foreign institutions" safeguarding digitized copies of the records; in July, Anna Carla Ericastilla, the chief archivist at the AGCA and a key figure in the AHPN leadership, was fired from her long-standing position at the national archives and spuriously accused of professional malfeasance; in September, CICIG was made to close its doors, its director barred from reentering the country.

In the past, such a flagrant campaign against such respected democratizing institutions would have been denounced in no uncertain terms by the U.S. Embassy and the State Department, but this time, the Trump administration said next to nothing, providing Morales with a carte blanche to dismantle the AHPN. In the words of one U.S. official, this reflected "an unwritten bargain" between the two countries: "They promise not to let brown people into the country, and we let them get away with everything else" (Lynch, 2019). And as Democratic congressional representative Norma Torres put it, "The message [Guatemalan authorities] are getting is we don't care what you do as long as you do everything in your power to prevent" foreigners from reaching the U.S. border (Lynch, 2019). Degenhart's announcement that the Morales government would end public and investigative access to the AHPN came on the same day that the Trump administration inaugurated its "safe third party agreement" with Guatemala, making the National Police archives a chess piece in a perverse stratagem to gut international asylum rights for refugee families throughout the Americas.

History shows, however, that the law is contested terrain: often bent by the powerful in defense of their own interests, of course, but nevertheless a site of real potential for those seeking justice. Midway through the Morales administration's war on the AHPN, a coalition of activists, led by the human rights ombudsman's office, filed a last-ditch legal appeal, or ámparo, denouncing the government's sabotage campaign and demanding the resurrection of the archival rescue operation. It sat on the Supreme Court's docket for nearly a year.

But on March 3, 2020, the justices issued a surprising ruling in favor of the activists. The Court not only ordered the relevant government ministries, Interior and Culture, to refrain from undermining the AHPN's physical and fiscal integrity, but also instructed them to reverse the damage of the preceding 18 months by restoring previous levels of staffing, support, and oversight, all per the international norms governing archival preservation 
and the defense of human rights. Finally, the ruling exhorted the country's Congress to approve draft legislation creating a new national archives law, which would more robustly protect initiatives like the AHPN from political interference in the future.

The ruling is welcome news - although its enforcement remains an open question. Morales's presidential term ended in January, but he was succeeded by another conservative, Alejandro Giammattei, linked to organized crime and military interests. And Giammattei has shown little inclination to reverse the course laid out by Morales. In February, for example, the Guatemalan Congress passed Decree 4-2020, which grants state authorities broad discretionary power to shut down civil society organizations, especially those which receive international funds or backing, whose activities are deemed to "disrupt public order." Decree 4-2020 was overturned by the Constitutional Court, though nothing prohibits Congress from reinitiating another legislative process designed to yield similar results - and the key message, that the government aims to rein in dissenting voices by any means possible, has already been communicated.

In short, this story is not over. What lessons might it hold for those working at the intersection of archival preservation and the defense of human rights?

First, if ever it was possible to sustain the premise that archival access and management were not fundamentally political, Guatemala conclusively demonstrates otherwise. State archives are never just papers. They are metaphors: for accountability, for the integrity of citizens' rights, for the depth of democratic transitions. But they are far more than metaphors, especially in a polarized post-counterinsurgency context like Guatemala's, where they represent a pair of dangers: that the intelligence information gathered in the past about human rights advocates could be weaponized against them a second time as they continue to seek justice, or, conversely, that the evidence of state responsibility for war crimes they contain could be used by those same human rights advocates to threaten the material interests of powerful sectors. It is a lot to expect of projects like the AHPN that they be able to navigate between Scylla and Charybdis without running aground.

Second, international partnerships can decisively boost the viability of efforts to save threatened archives - several statements by international allies were cited in the Supreme Court's March ruling - but they are not a panacea. On the one hand, without minimizing the labor and agency of the Guatemalans involved, it is difficult to imagine how the AHPN could have accomplished everything it did without the funding, training, and solidarity it received from abroad, whether from key individuals or from foreign states. Yet, on the other hand, international allies have little recourse if the national government is committed to starving or shutting down an archival rescue project, especially if that government is little interested in preserving its legitimacy. And in the case of Guatemala, the United States, which has historically wielded undue influence in the country, enabled the Morales 


\section{Kirsten Weld}

government's systematic onslaught against human rights and anticorruption efforts in exchange for the two-step quid pro quo of the Israel embassy move and cooperation in keeping migrants from seeking U.S. asylum. For as long as Trump remained in office, Guatemala's authoritarians - and the region's knew that they could probably get away, quite literally, with murder.

And, finally, the task of destabilizing official narratives about history and building bottom-up movements for accountability, representation, and justice is grueling and challenging. It fails far more often than it succeeds. And even when it does succeed - especially when it does - that success must be constantly defended, for it will be constantly threatened by those whose comfortable status quo it challenges. Politics is dialectical, not teleological. Human affairs do not inexorably improve, or become more just, in a linear fashion; democratic gains can be easily reversed. Guatemala's veteran activists, therefore, know that they must always keep playing the long game. As one AHPN worker reminded me (Weld, 2014), "Social victories are the fruit of the people's struggle, always. Nothing is easy, and it all represents a lot of work, no?"

\section{Notes}

1 Kirsten Weld's case study is written for this book but Routledge has granted permission for it to be published as an article in the Boston Review (9 July 2020).

2 These included the convictions of former National Police detective chief Pedro García Arredondo and former National Police director Héctor Bol de la Cruz in addition to ex-dictator Efraín Ríos Montt. On the Ríos Montt case, see Coronado, 2018.

\section{Bibliography}

Antonio, Simón. 2018, "La conspiración y persecución del estado contra la familia Molina Theissen," Prensa Comunitaria, 10 May. Available at www.prensacomu nitaria.org/la-conspiracion-y-persecucion-del-estado-contra-la-familia-molinatheissen/.

Burt, Jo-Marie, and Paulo, Estrada. 2018, "Four Retired Senior Military Officers Found Guilty in Molina Theissen Case," International Justice Monitor, 23 May. Available at www.ijmonitor.org/2018/05/four-retired-senior-military-officers-found-guiltyin-molina-theissen-case/.

Colombia 2020. 2018, "La condena de un militar motivó la salida del director del Archivo de Guatemala," El Espectador, 23 October. Available at www.elespec tador.com/colombia2020/justicia/verdad/la-condena-de-un-militar-motivo-lasalida-del-director-del-archivo-de-guatemala-articulo-857279.

Comisión para el Esclarecimiento Histórico (CEH). 1999, Guatemala: Memoria del silencio, 12 vols. Guatemala City: United Nations Office of Project Services.

Coronado, Elsa. 2018, "Ríos Montt: La muerte y la impunidad llegan juntas," Plaza Pública, 2 April. Available at www.plazapublica.com.gt/content/riosmontt-la-muerte-y-la-impunidad-llegan-juntas. 
Doyle, Kate. 2007. "The Atrocity Files: Deciphering the Archives of Guatemala's Dirty War,” Harper's Magazine, pp. 34-40.

—. 2018, "Guatemala Police Archive Under Threat." National Security Archive, 13 August. Available at https://nsarchive.gwu.edu/news/guatemala/2018-08-13/ guatemala-police-archive-under-threat.

Doyle, Kate, and Elizabeth, Oglesby. 2018, "Why Guatemala's Anti-Corruption Commission Faces a New Wave of Efforts to Derail It," World Politics Review, 23 May. Available at www.worldpoliticsreview.com/articles/24775/why-guatemalas-anti-corruption-commission-faces-a-new-wave-of-efforts-to-derail-it.

Goldman, Francisco. 2008, The Art of Political Murder: Who Killed the Bishop? New York: Grove Press.

Guberek, Tamy, and Hedstrom, Margaret. 2017, “On or Off the Record? Detecting Patterns of Silence About Death in Guatemala's National Police Archive," Archival Science, vol. 17, pp. 27-54.

Gutiérrez Valdizán, Alejandra. 2016, “El general volvió de su apacible retiro,” Plaza Pública. Available at www.plazapublica.com.gt/content/el-general-volvio-de-suapacible-retiro.

Jones, Maggie. 2016, “The Secrets in Guatemala's Bones,” The New York Times Magazine, 30 June. Available at www.nytimes.com/2016/07/03/magazine/thesecrets-in-guatemalas-bones.html.

Lynch, Colum. 2019, “Guatemala Declares War on History,” Foreign Policy, 30 July. Available at https://foreignpolicy.com/2019/07/30/guatemala-declares-waron-history-dirty-war-archives-jimmy-morales/.

Narea, Nicole. 2019, “Trump's Agreements in Central America Are Dismantling the Asylum System as We Know It," Vox, 20 November. Available at www. vox.com/2019/9/26/20870768/trump-agreement-honduras-guatemala-elsalvador-explained.

Noack, Rick. 2018, "Why Some Latin American Countries Are Rushing to Open Jerusalem Embassies, Too," The Washington Post, 16 May.

Open Society Justice Initiative. 2016, Against the Odds: CICIG in Guatemala. Available at www.refworld.org/docid/5799f4814.html.

Peters, Jeremy W. 2018, "How Trump-Fed Conspiracy Theories About Migrant Caravan Intersect with Deadly Hatred," The New York Times, 29 October.

Proyecto Interdiocesano de Recuperación de la Memoria Histórica (REMHI). 1998, Guatemala: Nunca más! Guatemala City: Oficina de Derechos Humanos del Arzobispado de Guatemala.

Rey Rosa, Rodrigo. 2009, El material humano. Barcelona: Editorial Anagrama.

Stelzner, Uli, dir. 2009, La Isla: Archives of a Tragedy. Iska Cine. Available at https:// www.imdb.com/title/tt1590791/.

Tomuschat, Christian. 2001. "Clarification Commission in Guatemala," Human Rights Quarterly, vol. 23, no. 3, pp. 233-258.

Weld, Kirsten. 2014, Paper Cadavers: The Archives of Dictatorship in Guatemala. Durham, NC: Duke University Press. 


\title{
Concluding remarks
}

\author{
Jens Boel, Perrine Canavaggio and \\ Antonio González Quintana
}

The Rohingyas in Myanmar or exiled in Bangladesh, the people of Yemen, the Uighurs in China... . The disasters continue, the "inunca más!" repeated so often seems like a vain and illusory cry in face of these ongoing crimes against humanity and gross human rights violations. However, resistance is possible against even the most powerful of tyrannies, surprising resistance sometimes, because it seems so vulnerable and fragile in all its simple humanity compared to the forces of dictatorships. The unarmed young student standing in front of the tank at the Tiananmen Square, Mahatma Gandhi marching peacefully, and thereby defying the colonial forces, Rosa Parks remaining at her seat in the "white" part of the segregated bus. ... In Part 2, Chapter 4 on Chad, Henri Thulliez reminds us of another humble hero, Rose Lokissim, who, from her prison cell, at the risk of her life, tried to let the truth of the torture and disappearings be known outside the dungeons. She paid the highest price, like so many before her. But she and thousands of other unsung heroes also proved that in the end evil can be defeated, perpetrators can be brought to justice and truth can prevail. In order to make this happen, records and archives are crucial and indispensable.

In Archives and Human Rights, we have discussed how records and archives can be used to document gross violations of human rights. We have done this both by way of a general overview and through 17 essays or case studies, covering situations in different parts of the world. We make no claim to have been comprehensive; every single country has one or multiple cases that could be discussed. However, as we wrote in the Introduction, if the examples presented here can inspire or inform efforts towards documenting human rights violations, then our objective has been achieved.

Among the lessons learnt from the case studies, we would like to highlight a few. First, that the trend towards international justice which was launched by the Nuremberg and Tokyo trials, and gained speed after the creation of the international tribunals for the former Yugoslavia (1993) and Rwanda (1994), far from being an irreversible development must be fought for again and again. Setbacks in countries like Brazil and Guatemala demonstrate this, as does the adamant opposition of the U.S. administration during the Trump presidency to the very notion of international justice. As recently as 
July 2020, the Russian Constitution was changed so that national legislation from now on will take precedence over international legislation; this represents yet another setback for international law.

At the same time, "sovereign immunity has eroded", as Trudy Huskamp Peterson notes in Part 2, Chapter 1, and the fight for the truth, justice and reparation in one country has often inspired human rights activists in other countries. Well-known cases are the South African Truth and Reconciliation Commission, the overturning of the amnesty laws in Argentina and the arrest of Pinochet in London by a Spanish judge in 1998. Vincent de Wilde d'Estmael in Part 2, Chapter 7 observes that the Cambodian example has inspired "the recent establishment by the United Nations of two impartial and independent mechanisms to collect, preserve and analyse evidence of the crimes committed in Syria and Myanmar".

This Cambodian example also demonstrates that transnational inspiration can lead to initiatives which have a proactive dimension. Gathering information, collecting records and building cases against perpetrators and for victims and their families, while the crimes are still going on, are essential activities in support of truth and justice. NGOs are indispensable partners in this effort, as is already the case in Syria. Reflecting and taking action on how such initiatives can best be initiated and encouraged are important challenges for individuals and organizations working for human rights. They are not new because some human rights organizations and many courageous individuals already do this kind of work; but the international community could take a systematic approach in favour of proactive activities, while taking into account existing practices and experiences.

A further lesson is the increased need for interdisciplinary cooperation in the work documenting gross human rights violations. Archivists play an essential role but cannot work alone; they need to join forces with other professionals, such as legal experts, forensic archaeologists, audio/sound and film experts, museum professionals, historians, political scientists, IT specialists and many others. The role of education (highlighted in the Tunisian and Cambodian case studies) is essential when it comes to using the archives in meaningful ways. Maybe the future generations should all be educated as historians! A critical understanding of the past and how to assess it (in particular by using archives) should be an integrated part of curriculum textbooks.

Although oral testimonies are precious, memory is fallible, and it is essential for the courts to be able to question witnesses, civil parties and experts on the basis of objective facts and precise dates as they appear in the records.

One striking conclusion of the case studies in this book is the huge variety of archival sources and categories that can serve to document human rights violations. Trudy Huskamp Peterson in Part 2, Chapter 1 provides a textbook example of this by methodically listing types of archives that can be used to document claims for compensation and reparation. Nevertheless, some archival fonds are little consulted in spite of their relevance and 
potential value. We are, in particular, thinking of archives of businesses, first of all multinational businesses. The deep involvement of ITT (International Telephone and Telegraph) with the CIA in preparing the 1973-coup against Allende in Chile, and of the United Fruit Company in Latin America over decades also mean that their archives could be relevant for studies of human rights violations. The cobalt wars in Congo and the use of private military and police forces in Iraq and elsewhere, provided by companies like Blackwater Security (now Academi), are other scenarios where business records could prove very helpful in documenting violations of human rights. As mentioned in Part 1 of this book (Archives and Human Rights: A Close Relationship), the UN Guiding Principles on Business and Human Rights (2011) do not mention the need to preserve records and archives, although businesses, in view of their track records, should not be ignored when it comes to fighting impunity and preventing abuse.

Archives and records on colonial crimes could have been studied in much more depth in the book. The case of France and Algeria is the topic of Part 2, Chapter 11 by Gilles Manceron and Gilles Morin, but there are other obvious cases after World War II, such as the United Kingdom and the Mau Mau movement in Kenya, which we encourage interested scholars to look further into from an archival perspective.

Looking ahead, use of archives and records can, in many different situations, help in promoting the Joinet Principles against impunity through the Right to Know, the Right to Justice and the Right to Reparation - with the ultimate goal of preventing repetitions - to become reality around the world. As Kirsten Weld in Part 2, Chapter 17 writes in her study of Guatemala, the work by archivists and others can "transform this archive of terror into an archive of justice". The scope of the challenge before us is vertiginous; just think of the need for China to become transparent about the millions of victims of the Cultural Revolution and other crimes and tragedies in recent history. All countries are facing challenges when it comes to dealing with painful chapters of the past. Amnesia is no solution. We believe that the studies in this book demonstrate that using records and archives in support of truth and justice can and will help in building sustainable and peaceful societies. 


\section{Index}

Abaïfouta, C. 143

Abakar, M. H. 140

Adenauer, K. 83

Aegis Trust 152

African National Congress (ANC)

115-117

Agamben, P. 294

Age of Enlightenment 12

Albania, compensation in 96-97

Alberch i Fugueras, R. 51, 54, 61

Al Chaab 238

Aldana, T. 315, 316

Alfonsín, R. 299

Algerian War 234-242

Alger Républicain 238

Alleg, H. 237

Almada, M. 2, 29

American Convention on Human

Rights 90-91

American Declaration of the Rights and

Duties of Man 90-91

Amnesty International 35

amnesty laws 21

Andersson, N. 237

Antonescu, I. 250

apartheid 115-116; see also South Africa; Truth and Reconciliation Commission, South Africa

Arbenz, J. 310

Arce Gómez, L. 46

archives: conclusions on 320-322;

experiences in post-communist

European countries 51-53; and

human rights in the business community 63-67; of human rights

NGOs 33-37; of international tribunals and truth commissions 37-40; introduction to human rights history and 1-7; memory and 54-56; parallel history of human rights and public 11-14; as part of democracy 12; right to access 14-20; right to justice and 44-48; right to reparation and $48-51$; right to truth and 42-44; of security services of former repressive regimes 27-33

Archives and Dealing with the Past 61 archives of terror 29

archivists, human rights 57-62

Archivists without Border (AwB) 61

Arendt, H. 47, 249

Argentina: archives of the memory, research teams and general archives in 301-305; compensation in 92-93; conclusions on 305-306; documents on missing persons in 297-299; introduction to 296-297; public policies in response to demand for memory, truth and justice and archive documents in 299-301

Armstrong, A. 86

Ash, T. G. 4

Audin, J. 234

Audin, M. 234-235, 237, 239

Aylwin, P. 38

Bachelet, M. 6, 38

Baldetti, R. 314

Ball, P. 142-143, 147

Balladur, E. 232

Barbie, K. 46-47

Băsescu, T. 248, 251, 253, 254

Basic Principles and Guidelines on the Right to a Remedy and Reparations for Victims of Gross Violations of International Human Rights Law and Serious Violations of International Humanitarian Law 89-90 


\section{Index}

Basic Principles on the Right to Remedy and Reparation for Victims of Gross Violations 50

Basic Principles on the Role of Lawyers 61

Basic Principles on the Roles of Archivists and Records Managers in Support of Human Rights 61-62, 108

Bassiouni, C. 49-50, 89

Beccaria, C. 12

Ben Ali, Z. E.-A. 126, 128, 131-132

Benjamin 290

Ben Youssef, S. 132

Bercault, O. 141-142

Bignone, R. 29

Bill of Rights, U. S. 11-12

Bokova, I. 171

Bolotte, P. 236

Bolsonaro, J. 6

Botha, P. W. 117

Boucif, M. 240

Boucif, S. 240

Bouhired, D. 237

Bourguiba, H. 126, 131

Bousquet, R. 47

Braibant, G. 3, 232

Brandt, W. 213

Brazil: archives and truth in 293-294; compensation in 94-95; final considerations on 294; military dictatorship in 288-289; National Truth Commission and use of archives in 290-293; transitional justice in 289-290

Brody, R. 141-142

Brooks, R. L. 84

Brothman, B. 54, 60

Buenos Aires Provincial Memory Committee (CPM: Comisión Provincial por la Memoria) 301-302

Bulgaria: Centres of Remembrance and 211; compensation in 97

business community human rights $63-67$

Cadelo, V. 23

Cambodia see Extraordinary Chambers in the Courts of Cambodia (ECCC)

Camus, A. 149

Canada, compensation in 98

Capaldo, G. 48

Cardoso, R. M. 293

Ceauşescu, N. 248, 253-255

Centres of Remembrance: as archives of the secret police 206-211; conclusions on 215; structure and functions of the communist secret police and 204-206; use and abuse of 212-215

Chhang, Y. 184

child/parent relationships, records establishing 102-103

Chile 36-37, 51; compensation in 95

China Daily 169

Chodakiewicz, M. J. 213

Cibulka, P. 214

civil society organizations 33-34

Civil War, U.S. 84-85

Clinton, B. 5

Colóm, Á. 314

Colombia 51, 55, 83; central nature of archives in 266-271; challenges for archives in 271-273; historical and political context in 263-265; legal framework in 265-266

Colombia National Centre for Historical Memory 55

Colonomos, A. 86

Commission for the Clarification of Truth, Coexistence and NonRepetition (CEV) 270-271

Communist Party of Peru-Shining Path (PCP-SL: Partido Comunista del Perú-Sendero Luminoso) 277

communist secret police, European: archives of 206-211; structure and function of 204-206; use and abuse of archives of 212-215

compensation 83-84, 107-108; in Albania 96-97; archivists roles in documentation for 106-107; in Argentina 92-93; background on 84-86; in Brazil 94-95; in Bulgaria 97; in Canada 98; in Chile 95; impact of World War II on 86-87; individual litigation and 85 ; international law and 85 ; international setting for 88-91; national efforts in 91-100; role of records in 100-107; in Russia 97-98; in the United States 98-100

Comprehensive System of Truth, Justice, Reparation and NonRepetition (SIVJRNR, Sistema Integral de Verdad, Justicia, Reparación y No Repetición) 270

Conference of the Round Table on Archives (CITRA), Mexico 57

Constantinescu, E. 251

Convention Respecting the Laws and Customs of War on Land 84 
Cook, T. 60

Council of Europe 18, 20

Courrégé, M. 237

Craig, B. 54-55

Crenzel, E. 296, 300

Czech Republic/Czechoslovakia 52-53;

Centres of Remembrance and 211, 214

Dara, V. 184

Das Leben der Anderen (The Lives of Others) 4

David, R. 52

death certificates 103

Déby, I. 138, 140

Declaration of Basic Principles of Justice for Victims of Crime and Abuse of Power 88-89

Declaration of the Right of Man and of the Citizen 12-13

Degenhart, E. 316

de Greiff, P. 25-27, 37

Dei delitti e delle pene (On Crimes and Punishments) 12

de Klerk, F. W. 117-118, 120

Demba, N. 143

Demerliac, F. 242

democracy, archives as part of 12

Derrida, J. 294

Digeser, P. 251

DNA records 101, 102-103

Documentation and Security Directorate (DDS), Chad: archives compromising France and the United States 148-149; Commission of Enquiry and archives of 140-141; as Habré's political police 139-141; HRW's discovery of archives of 141-145; judiciary use of archives of 145-146; trial of Hissène Habré and archives of 147-148

Documentation Centre of Cambodia see Extraordinary Chambers in the Courts of Cambodia (ECCC)

Duchein, M. 11

Duggan, J.-A. 119

Echeverría, L. 252

Eichmann, A. 47

electronic environments, human rights in 64-66

Elias, A. 38

El Salvador Truth Commission 37

El Silencio de Otros (The Silence of Others) 4

Ericastilla, A. C. 316
Euro-Mediterranean Association against Enforced Disappearances (FEMED) 33

Europe: Centres of Remembrance in 206-211; communist secret police in 204-215; compensation in 96-98; see also individual nations

exile, records of 105-106

Extraordinary Chambers in the Courts of Cambodia (ECCC) 185-186; historical, political, social and cultural contexts of 178-180; nature of the archives of Democratic Kampuchea found and methods of conservation by 181-184; reliability and authenticity of the archives of Democratic Kampuchea and 184-185; usefulness of the Democratic Kampuchea archives versus oral testimony in 180

Fall, M. 146

Faraldo, J. M. 53, 54

File, The 4

Foucault, M. 290

France: Constitution of 12-13; DDS archives compromising 148-149; see also French National Archives

Franco, F. 44, 50, 191-192; summary trials of military justice during regime of 197-201; see also Spanish Civil War

Freedom of Information Act, 1966 17-18, 20

French Association of Contemporary Historians in Higher Education and Research (AHCESR) 242

French National Archives: of colonial wars, including the Algerian War 234-239; establishment of 230; "Giscard" law of 3 January 1979 and 231-232; military secrecy as crucial civic issue for France and 242; need for general exemption extending to all archives of the colonial era and 241; "Sarkozy" law of 15 July 2008 and 232-234; scope for general exemption 239-241; under state control in the Third Republic 230-231; see also France

Fricker, D. 67

Fujimori, A. 277

Fumio, K. 171-172

Gacaca Archive, Rwanda: access to 162-163; alternative methodology 161 ; archiving by $158-159$; contents of 159-160; Gacaca courts and 154-158; genocide and the 


\section{Index}

introduction to 152-154; goals of 160 ; impartiality of staff of 159 ; introduction to 152; metadata of 161-162; progress of 160-163; records creating for 158; traditional methodology 160-161

Gaddafi, M. 148

García Meza, L. 46

Garçon, M. 236

Garzón Real, B. 2-3, 44, 48

Gaye, D. 143-144

General Archive of the Nation (AGN: Archivo General de la Nación) 303

General Data Protection Regulation (GDPR) 65

Genro, T. 289

Gerardi Conedera, J. J. 311

Germany 14-15; archives in 28-29; Centres of Remembrance and 206-208, 212; lustration and 52; reparations by $86-87$; see also Nuremberg Trials; Stasi Records Archive

Giammattei, A. 317

Giscard d'Estaing, V. 231-232

Gomez Bravo 191

González Poblete, A. 38

González Quintana, A. 57, 59

Granito: How to Nail a Dictator 4

Guatemala 37, 51; establishment of Historical Archives of the National Police (AHPN) in 309-310; history of violent internal conflict in 310-314; Jimmy Morales as president of 314-316; Supreme Court ruling in favor of AHPN in 316-318

Guatemala Historical Clarification Commission 37

Gueye, A. 144

Gustafsson, K. 3

Guzmán Reynoso, A. 277, 285

Gysi, G. 212

Habineza, J. 163

Habré, H. 29, 138-139; trial of 147-148; see also Documentation and Security Directorate (DDS), Chad

Hague Convention 84

Haiti 13-14

Halter, M. 1

harm, records establishing 103-106

Harris, V. 60, 120

Hazan, P. 141-142
Heald, C. 60

Hiroshi, H. 171

Hobsbawm, E. 28

Hollande, F. 238-239

Honduras 91

Hoover, J. E. 253

Hovestädt, D. 53

Hua Chunying 172

Humala, O. 285

human rights: archivists for 57-62; in the business community 63-67; in electronic environments 64-66; introduction to archives and 1-7; Joinet Principles and 2-3, 22-23; making of international law in 14-20; parallel history of public archives and 11-14; United Nations and 21-27

Human Rights Watch (HRW) 138; archives compromising France and the United States 148-149; discovery of Documentation and Security Directorate (DDS) archives by 141-145

Human rights Working Group of the International Council on Archives (HRWG) 63-64

Hungary, Centres of Remembrance and 211

identity, records in establishing 100-103

Ignatieff, M. 251

Iliescu, I. 251

Information Centre for the Collective Memory and Human Rights (CIMCDH: Centro de Información para la Memoria Colectiva y los Derechos Humanos) 281-282

Integral System of Truth, Justice, Reparation and Non-Repetition (SIVJRNR) 267

Inter-American Commission on Human Rights (IACHR) 19-20, 23

Inter-American Court of Human Rights 91

International Centre for Transitional Justice (ICTJ) 41

International Commission on the Holocaust (ICHR) 250, 252

International Convention for the Protection of All Persons from Enforced Disappearances 34

International Convention on Civil and Political Rights (ICCPR) 16 
International Council on Archives (ICA) 58-59, 62, 66-67

International Covenant on Civil and Political Rights 88

International Criminal Court (ICC) 21, $39,44,47$

International Military Tribunal (IMT) $14-15$

international tribunals, archives of 37-40

Investigation and Prosecution Unit (IUA, Unidad de Investigación y Acusación) 270

IVD see Truth and Dignity Commission, Tunisia

Jahn, R. 225

Jenkinson, H. 159

Joinet, L. 22, 23, 60

Joinet Principles 2-3, 22-24, 57, 123,236

Judt, T. 52, 247-248

justice, right to $44-48$

Kam, G. G. 148

Ketelaar, E. 43, 60

Khmer Rouge see Extraordinary Chambers in the Courts of Cambodia (ECCC)

Kirchner, N. 300

Klingner, J. 143

Kornbluh, P. 20

Kotaro, N. 171

Kundera, M. 214

Kuraś Ogień, J. 213

Kurras, K.-H. 213

La ciudad de los fotógrafos 4

La Isla - Archives of a Tragedy 4

Lanzman, C. 1

Latin America: archives in 29-33, 36-37, 51; compensation in 92-95; see also individual nations

Latin-American Federation of Associations for the Relatives of the Detained and Disappeared (FEDEFAM) 33

Le Cabier Vert 237

Leitenberg, M. 28

Leprince, C. 240

Liberia 38

Lokissim, R. 144-145

Los archivos del cardenal (The Archives of the Cardinal) 4

Lost: A Search for Six of Six Million, The 4-5
Lula da Silva, L. I. 291

lustration 51-53, 209, 214, 250

Macri, M. 305

Macron, E. 5, 234, 236, 239, 241

Magna Carta 11

Makita, S. 173

Mandela, N. 115, 116, 117

Mapping Archives for Dealing with the Past Processes 61

Margalit, A. 249

Marzouki, M. 126

McFarland, S. 314

McNeil, L. 60

Meciar, V. 214

medical condition records 103-105

Memorialization Processes in the Context of Serious Violations of Human Rights and International Humanitarian Law: The Fifth Pillar of Transitional Justice 27

memory: archival concept of 54-56; sharing of 59-60

Mendelsohn, D. 4

Menem, C. 300

Meoño, G. 313, 314

meritorious redress claim 84

Mexico 57

Millar, L. 55

Modernisation Programme for the Defence Archive System (Programa de Modernización del Sistema de Archivos del Área de la Defensa) 303

Molina Thiessen, E. G. 314, 315-316

Mollier, J.-Y. 242

Morales, J. 314-315, 317

Moreno, S. 4

Mothers and Grandmothers of the Plaza de Mayo, Argentina 33

Museum of Memory 38

Nanjing massacre see Sino-Japanese relations

National Archives (AGN, Archivo General de la Nación) 265-271

National Centre for Historical Memory (CNMH, Centro Nacional de Memoria Histórica) 266-271

National Commission for Fight against Genocide (CNLG) 152

National Commission for the Disappearance of Persons (CONADEP: Comisión Nacional por la Desaparición de Personas) 298

National Security Archive (NSA) 20 
Nature of the General Legal Obligation Imposed on States Parties to the International Covenant on Civil and Political Rights, The 90

Nazar, M. 29

Nesmith, T. 60

New York Review of Books, The 247

Nietzsche, F. 247

nongovernmental organizations

(NGOs), archives of human rights 33-37

North America, compensation in 98-100

Nunca Más - "Never Again” 5

Nuremberg Principles 14-15, 48

Nuremberg Trials 14-15, 45-46; Klaus Barbie and 46-47

Ohnesorg, B. 213

Olaru, S. 255

Ollé, M. 47

Omar, D. 115

Operation Condor 2

Oprea, M. 255

Orentlicher, D. 23

Organization of American States (OAS) $35,90-91$

Panh, R. 4

Paniagua Corazao, V. 277-278

Papon, M. 47, 232, 242

Paz y Paz, C. 314

Pérez Molina, O. 313-314

Permanent Court of International Justice 85

Peru 38; times of internal armed conflict (CAI) in 277-278

Peruvian Commission for Truth and Reconciliation (CVR): creation of Documentation Unit of 278-279; current challenges for preservation and dissemination of heritage of 286; progress and setbacks in the implementation of recommendations of 284-286; reparations to victims and 282-283; series produced by 279-280; strengthening the memory 283-284; times of the internal armed conflict (CAI) and 277-278; utilisation by institutions for dissemination of the Final Report, strengthening of the collective memory, justice and reparations 280-282; utilisation of public and private archives for investigation work of 278-279
Peterson, T. H. 23, 27, 39, 44, 48, 60, 120

Petrescu, D. 210

Pinheiro, S. 50

Pinochet, A. 20, 47-48, 138

Poland, Centres of Remembrance and 208, 210, 213

Popescu-Tăriceanu, C. 248

post-truth 3

Powell, C. 5

prison records 105-106

Quinhala, R. H. 289

Rahal, M. 236, 238

Recommendation Rec 18-19

records: establishing harm 103-106; establishing identity 100-103; role in compensation 100-107

Red Cross International Tracing Service Archive 43

reparation, right to 48-51

Republic of the Marshall Islands 99-100

Rettig, R. 38

Riceputi, F. 236

Ricoeur, P. 288

Ridener, J. 60

right to justice $44-48$

right to truth 42-44

Ríos Montt, E. 314

Rivonia Trial 116

Rodríguez, H. A. 44

Romania: Centres of Remembrance and 210; commission and democratization of archives in 253-255; condemnation of communist regime in 255-256; context of 247-249; introduction to 247; before the presidential commission 250-251; reactions to the condemnation and political rearrangements in, after 2007 252-253; reckoning with the past in comparative perspective 249-250

Roosevelt, F. D. 98

Rousseff, D. 291

Ruggie, J. 62

Ruggie principles 62, 64

Russia, compensation in 97-98

Rwanda see Gacaca Archive, Rwanda

S21: The Khmer Rouge Death Machine 4

Salinas, A. 50

Sall, M. 146

Salvioli, F. 27

Sánchez, G. 263 
Santana, M. A. 293

Sarkozy, N. 232-234

Schneider, P. 250

Schwartz, H. 52

Search Unit for Missing Persons (UBPD) 271

Sebald, W. G. 4-5

security services archives 27-33

Shoah 1

Silva, R. 143

Sino-Japanese relations 3, 174-175; archives of $168-169$; introduction to 167-168; uses of archives and their role in memory politics of 170-174

Sorrow and the Pity, The 4

South Africa 38, 58; African National Congress (ANC) in 115-117; destroyed evidence in 117-118; National Archives and sensitive records in 118-119, 122-123; see also Truth and Reconciliation Commission, South Africa

Spanish Civil War: archival policies of military documentation during the dictatorship, Spanish Transition, and 192-197; memory condemned at end of 191-192; summary trials of military justice during the Franco regime and 197-201

spousal identity, records establishing 101-102

Stampa, I. 293

Stan, M. 53

Stasi Records Archive: future of 224-225; introduction to 218; people's uprising in 1989 and 220-221; reappraisal of the past using 221-224; records of repression in 218-220

Stolpe, M. 212

Storey, R. G. 45

Stroessner, A. 29

Supreme Council of the Armed Forces (CONSUFA: Consejo Supremo de las FF.AA.) 304

Teitgen, P. 236

Thulliez, H. 29, 48

Tismaneanu, V. 53, 251

Toledo, A. 282

Tomasz Gross, J. 209, 213

Tomomi, I. 171

Touvier, P. 47

transitional justice: in Brazil 289-290; compensation in (see compensation); cornerstones of 41-42; defined 41; experiences in post-communist
European countries 51-53; right to justice and 44-48; right to reparation and 48-51; right to truth and 42-44

Trump, D. 315,316

truth, right to 42-44

Truth and Dignity Commission, Tunisia: collection policy for records relevant to work of 128-130; conclusions on 135; difficulties encountered by $130-131$; establishment of 126; future of the archives and their use as part of a policy of remembrance 134-135; recommendations of 133-134; results of work of 131-133; roles and powers of $126-128$

Truth and Reconciliation Commission, Liberia 38

Truth and Reconciliation Commission, Peru 38

Truth and Reconciliation Commission, South Africa 38, 115, 124; accessing sensitive records of 122-123;

archiving of records by 120-122; background of 115-117; destroyed evidence and 117-118; hunt for archives of oppression by 119-120; introduction to 115; National Archives, sensitive records and 118-119

truth commissions, archives of 37-40

Tudor, C. V. 248

Tunisia see Truth and Dignity Commission, Tunisia

Tuol Sleng Genocide Museum 181-186

Tutu, D. 38, 58, 115, 138

UNESCO 2, 3, 61, 168

UN Guiding Principles on Business and Human Rights 62, 63

United Nations 21-27; Guiding Principles on Business and Human Rights 64; on right to reparation 48-50; Universal Declaration of Human Rights 16, 19, 88

United States, the: compensation of Japanese-Americans in 98-99; DDS archives compromising 148-149; Republic of the Marshall Islands and 99-100

Universal Declaration of Human Rights $16,19,88$

Universal Declaration on Archives 61

Valech, S. 38, 95

Vallat, F. 240 


\section{Index}

van Boven, T. 49, 89-90

Van Zyl, P. 289

Varsky, C. 298

Velasquez Rodriguez, A. M. 91

Vergès, J. 237

Verwoerd, H. 116

Vidal-Naquet, P. 234-235, 237

Villa-Vicencio, C. 250

Wałęsa, L. 214

Weikart, S. 143

Weil, S. 149

What Is Left of Auschwitz 294
Wiesel, E. 250

World Conference on Human Rights 21-22

World Council of Churches 35

World War I 85

World War II 14-15, 83; individual litigation after 85 ; state-to-state reparations after 86-87; see also Nuremberg Trials

Yasuhisa, K. 170

Zavrian, M. 237

Zhu Chengshan 172 